\title{
CLOSURE OF HAZARDOUS AND MIXED RADIOACTIVE WASTE MANAGEMENT UNITS AT DOE FACILITIES
}

\author{
June 1990
}

\author{
PREPARED BY:
}

U.S. DEPARTMENT OF ENERGY

OFFICE OF ENVIRONMENTAL GUIDANCE RCRA/CERCLA DIVISION

EH-23

TECHNICAL SUPPORT:

PACIFIC NORTHWEST LABORATORIES ICF INCORPORATED 


\section{DISCLAIMER}

This report was prepared as an account of work sponsored by an agency of the United States Government. Neither the United States Government nor any agency thereof. nor any of their employees, makes any warranty, express or implied, or assumes any legal liability or responsibility for the accuracy, completeness, or usefulness of any information, apparatus, product, or process disclosed, or represents that its use would not infringe privately owned rights. Reference herein to any specific commercial product. process, or service by trade name, trademark, manufacturer. or otherwise does not necessarily constitute or imply its endorsement, recommendation, or favoring by the United States Government or any agency thereof. The views and opinions of authors ex. pressed herein do not necessarily state or reflect those of the United States Government or any agency thereof.

This report has been reproduced directly from the best available copy.

Available to DOE and DOE contractors from the Office of Scientific and Technical Information, P.O. Box 62, Oak Ridge, TN 37831; prices available from $(615) 576-8401$.

Available to the public from the National Technical Information Service, U.S. Department of Commerce, 5285 Port Royal Rd., Springfield, VA 22161. 


\section{DISCLAIMER}

Portions of this document may be illegible in electronic image products. Images are produced from the best available original document. 


\section{TABLE OF CONTENTS}

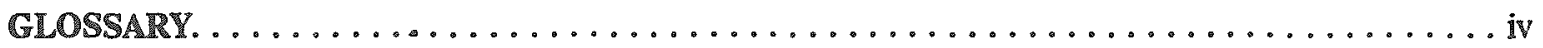

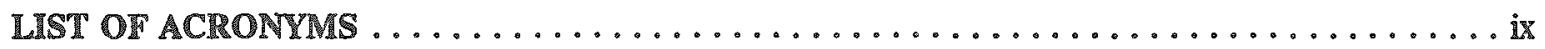

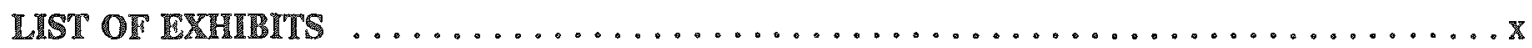

CHAPTER 1:

1.1

1.2

1.3

\section{CHAPTER 2:}

2.1

\section{CHARTRER:}

INTRODUCTION $\ldots \ldots \ldots \ldots \ldots \ldots \ldots \ldots \ldots \ldots$

PURPOSE OF THIS DOCUMENT $\ldots \ldots \ldots \ldots \ldots \ldots \ldots \ldots$

SCOPE OF THIS DOCUMENT $\ldots \ldots \ldots \ldots \ldots \ldots \ldots \ldots \ldots \ldots$

ORGANIZATION OF THIS DOCUMENT ...............

OVETVIEW OF HAZARDOUS AND RADIOACTIVE MIXED WASTE MANAGEMENT REQUIREMENTS ...............

RESOURCE CONSERVATION AND RECOVERY ACT (RCRA) . . 2-1

The RCRA Permiting Program . . . . . . . . . . . . . . . . . 2-2

Identification and Listing of Hazardous Wastes ............. 2 -9

Facility Design and Operating Standards. . . . . . . . . . . . 2-17

Land Disposal Restrictions .................... 2.25

ATOMIC ENERGY ACT $\ldots \ldots \ldots \ldots \ldots \ldots \ldots .27$

DOE ORDERS ...........................2.27

DOE 5400.1: General Environmental Protection Program . . . . . . . . 2-28

DOE 5400.3: Hazardous and Radioactive Mixed Waste Program . . . . . . 2-28 DOE 5400.5: Radiation Protection of the Public and the Environment . . 2-28 DOE 5480.11: Radiation for Occupational Workers ... . . . . . . 2-29 DOE 5820.2A: Radioactive Waste Management ............. 2-29

FEDERAL FACILITY COMPLIANCE AGREEMENTS $\ldots \ldots \ldots .2-32$

PROCEDURAL REQUTREMENTS TOR CLOSING PAZARDOUS AND MIXED

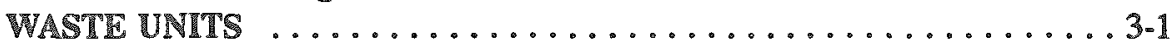

THE SUBPART G CLOSURE REQUIREMENTS ...........

The Closure Performance Standard ................... . . .

The Closure Plan ............................. 3

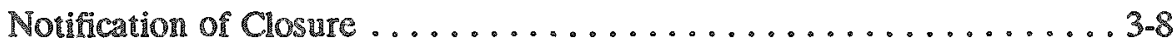

Triggers of Closure. ................................

Time Allowed for Closure Activities . . . . . . . . . . . . . . 3-12

Disposal or Decontamination of Equipment, Structures and Soils . . . . 3-12

Certification of Closure ...................... .

Survey Plats and Post-Closure Notices .....................

THE SUBPART G POST-CLOSURE CARE REQUIREMENTS . . . . 3-16

Length of the Post-Closure Period ..................

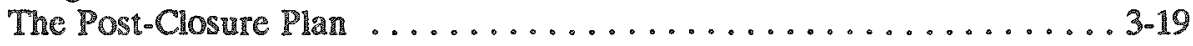

CONTINGENT CLOSUREROST-CLOSURE PLANS $\ldots \ldots \ldots \ldots 3-21$ 
TARLE OF CONTENTS (Continued)

CHAPTER 4: TECHNICAL REQUIREMENTS FOR CLOSING HAZARDOUS AND MIXED WASTE

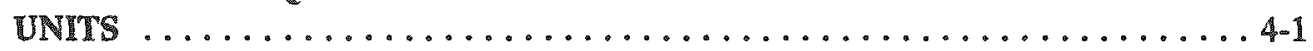

$4.1 \quad$ LANDFILLS $\ldots \ldots \ldots \ldots \ldots \ldots \ldots \ldots \ldots \ldots \ldots \ldots \ldots \ldots \ldots . . \ldots \ldots \ldots$

4.1.1 What are the Closure Requirements for Landfills? ............. 4-3

4.1 .2 Closure of Landfills ......................... 4-4

4.1.3 Additional RCRA Requirements to Consider ............ 4-23

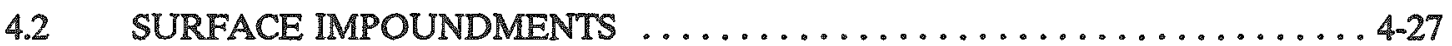

4.2.1 What are the Closure Requirements for Surface Impoundments? . . . . 4-27

4.2.2 Selecting Surface Impoundment Closure Options ............ 4-31

4.2.3 Clean Closure of Surface Impoundments .............. 4-32

4.2.4 Landfill Closure of Surface Impoundments . . . . . . . . . . . . . 4-43

4.2 .5 Additional RCRA Requirements to Consider ............4.52

4.3 WASTE PILES $\ldots \ldots \ldots \ldots \ldots \ldots \ldots \ldots \ldots \ldots \ldots \ldots \ldots \ldots \ldots \ldots . \ldots \ldots \ldots$

4.3.1 What are the Closure Requirements for Waste Piles? .......... 4-55

4.3.2 Clean Closure of Waste Piles ...................... 4-57

4.3.3 Landfill Closure of Waste Piles ....................... 4-66

4.3.4 Additional RCRA Requirements to Consider ............. 468

4.4 LAND TREATMENT ........................... 471

4.4.1 What are the Closure Requirements for Land Treatment Facilities? . . . 4 471

4.4.2 Closure of Land Treatment Facilities .................. 4. 43

4.4.3 Additional RCRA Requirements to Consider ... . . . . . . . . . . . 4-80

4.5 CONTAINER STORAGE AREAS ..................... 43

4.5.1 What are the Closure Requirements for Container Storage Areas? . . . . 4-83

4.5 .2 Closure of Container Storage Areas . . . . . . . . . . . . . 4.84

4.5.3 Additional RCRA Requirements to Consider .............. 4.89

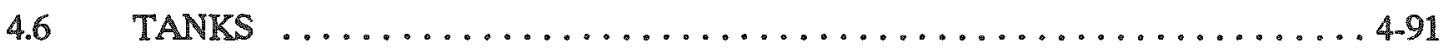

4.6.1 What are the Closure Requirements for Tanks? ........... 4-91

4.6.2 Closure of Tank Systems ....................... . 4-93

4.6.3 Additional RCRA Requirements to Consider .............. 4-107

4.7 INCINERATORS ............................ $4-111$

4.7.1 What are the Closure Requirements for Incinerators? . . . . . . . 4-112

4.7 .2 Closure of Incinerator Facilities . . . . . . . . . . . . . . . 4-113

4.7.3 Additional RCRA Requirements to Consider .............. 4-116

4.8 MISCELLANEOUS UNITS ....................... 4-119

4.8.1 What are the Closure Requirements for Miscellaneous Units? . . . . . 4-120

4.8.2 Closure of Miscellaneous Units . . . . . . . . . . . . . . . . 4-121

4.8.3 Closure and Post-Closure Care of Interim Status Miscellaneous Units . . 4-122

4.8.4 Additional RCRA Requirements to Consider .............. 4-122 


\section{TABLE OF CONTENTS (Continued)}

4.9 UNDERGROUND INJECTION WELLS ................. 4-125

4.9.1 What are the Closure Requirements for Underground Injection Wells? . 4-125

4.9.2 Closure of Underground Injection Welis . . . . . . . . . . . . 4-127

4.9.3 Additional RCRA Requirements to Consider ............... 4-133

APPENDIX A: EPA's "Contained-in" Policy $\ldots \ldots \ldots \ldots \ldots \ldots \ldots \ldots \ldots \ldots \ldots \ldots$

APPENDIX B: DOE Guidance Memorandum on RCRA Corrective Action Requirements ..... B-1

APPENDIX $\mathbf{C}$ : Placement and Disposal $\ldots \ldots \ldots \ldots \ldots \ldots \ldots \ldots \ldots \ldots \ldots \ldots \ldots \ldots$

APPENDIX D: Joint NRC-EPA Guidance on Conceptual Design of

Radioactive Mixed Waste Management Unit Closures ............... D-1

APPENDIX E: DOE and EPA Memoranda on LDRs and Ground-Water

Treatment Reinjections ........................... E-1

APPENDIX F: DOE Memorandum on Proposed RCRA Siting Restrictions . . . . . . . . . . F-1

APPENDIX G: EPA Memorandum on Equivalency Demonstrations $\ldots \ldots \ldots \ldots \ldots \ldots \ldots$. . . .

APPLNDIX H: Joint NRC-EPA Guidance on Siting of Mixed

Low-Level Radioactive and Hazardous Waste Units ................H-1 


\section{GLOSSARY}

Active life -. The period from the initial receipt of hazardous waste at the facility unil the Regional Administrator receives certification of final closure.

Ancillary equipment -- Any device including, but not limited to, such devices as piping, fittings, flanges, valves, and pumps, that is used to distribute, meter, or control the flow of hazardous waste from its point of generation to a storage or treatment tank(s), between hazardous waste storage and treatment tanks to a point of disposal on-site, or to a point of shipment for disposal off-site.

Atomic Energy Act -- Authorizes DOE to regulate radioactive material operations at many governmentowned facilities and several inactive sites that contain radioactive contamination.

Bathtub effect -- The liquid buildup and eventual overflow due to precipitation which enters the unis through the cover but cannot escape through the bottom liner.

Byproduct materials -- Any radioactive material (except special nuclear material) yielded in or made radioactive by exposure to radiation incident to the process of producing or utilizing special nuciear material; and the tailings or wastes produced by the extraction or concentration of uranium or thorium from any ore processed primarily for its source material content.

California wastes - A group of liquid hazardous wastes, including ones with PCB's, heavy metals, and halogenated organic compounds that EPA had to evaluate by July 8,1987 , to determine if they should be banned from land disposal or if restrictions should be placed on the land disposal of these wastes.

Characteristic waste - A solid waste defined as hazardous because it exhibits one of the following four characteristics: ignitability, corrosivity, reactivity, or toxicity.

Clean closure -- Removal and/or decontamination of all wastes from a disposal facility.

Closed portion - That portion of a facility which an owner or operator has closed in accordance with the approved facility closure plan and all applicable closure requirements.

Container -- Any portable device in which a material is stored, transported, treated, disposed of, or otherwise handled.

Culvert -- Directs surface run-on and run-off away from the disposal area and prevents surface water from infiltrating the cover.

Disposal -- The discharge, deposit, injection, dumping, spilling, leaking, or placing of any solid waste or hazardous waste into or on any land or water so that such solid waste or hazardous waste or any constituent thereof may enter the environment or be emitted into the air or discharged into any waters, including ground waters.

Disposal facility - A facility or part of a facility at which hazardous wasse is intentionally placed into or on any land or water, and at which waste will remain after closure.

Drainage layer -- Design to promote the rapid and efficient transport of water from the cover to an exit drain. May be comprised of either granular or geosynthetic materials. 
Effluents -- Waste materials discharged into the environment.

Elementary neutralization unit -- A device which: (1) Is used for neutralizing wastes which are hazardous wastes only because they exhibit the corrosivity characteristic defined in 40 CFR \$261.22, or are listed in Subpart D of Part 261 only for this reason; and, (2) Meets the definition of tank, container, transport vehicle, or vessel in $40 \mathrm{CFR} \$ 260.10$.

Equivalency demonstration -- For interim status facilities to show that closure satisfies all the requirements specified for permitted facilities in Part 264, even if the facility was otherwise subject to the interim status requirements.

Evapotranspiration -- Loss of water from the soil both by evaporation and by transpiration from the plants growing thereon.

Facility -- (40 CFR 260.10) -- All contiguous land, structures, other appurtenances, and improvements on the land, used for treating, storing, or disposing of hazardous waste. A facility may consist of several treatment, storage, or disposal operational units (e.g., one or more landfills, surface impoundments, or combinations of them).

Final closure -- The closure of all hazardous waste management units at the facility in accordance with all applicable closure requirements so that hazardous waste management activities under 40 CFR Parts 264 and 265 are no longer conducted at the facility unless subject to the provisions in 40 CFR $\$ 262.34$.

Flanges -- Part of ancillary equipment used in tank systems.

Gunnite -- Type of liner.

Hazardous waste -- (40 CFR 261.3) -- A solid waste, or combination of solid wastes, which because of its quantity, concentration, or physical, chemical or infectious characteristics may--(a) cause, or significantly contribute to an increase in mortality or an increase in serious irreversible, or incapacitating reversible, illness; or (b) pose a substantial present or potential hazard to human health or the environment when improperly treated, stored, transported, or disposed of, or otherwise managed.

Hazardous Waste Management Unit -- A contiguous area of land on or in which hazardous waste is placed, or the largest area in which there is significant likelihood of mixing hazardous waste constituents in the same area. Examples of hazardous waste management units include a surface impoundment, a waste pile, a land treatment area, a landfill cell, an incinerator, a tank and its associated piping and underlying containment system and a container storage area. A container alone does not constitute a unit; the unit includes containers and the land or pad upon which they are placed.

High-level radioactive waste -- The material that results from the reprocessing of spent nuclear fuel, including liquid waste produced directly in reprocessing and any solid waste derived from the liquid, that contains a combination of transuranic waste and fission products in concentrations requiring permanent isolation.

Incinerator - Any enclosed device using controlled flame combustion that neither meets the criteria for classification as a boiler nor is listed as an industrial furnace.

In-situ (waste treatment) -- Literally means on-site.

Intake -- The amount of substance taken into the body per unit body weight per unit time and is calculated separately for each environmental medium--air, ground water, surface water, and soil. 
Interim status -- Established under Section 3005(e) of RCRA. It allows owners and operators of facilities in existence by November 19,1980 (or brought under Subtitle C due to an amendment) who meet certain conditions to continue operating until a final permit application is approved or denied.

Isogram plan -- Type of plan prepared to guide the level of cleanup required at various areas within a container storage system.

Landfill -- A disposal facility or part of a facility where hazardous waste is placed in or on land and which is not a pile, a land treatment facility, a surface impoundment, an underground injection well, a salt dome formation, a salt bed formation, an underground mine, or a cave.

Leachate - Any liquid, including any suspended components in the liquid, that has percolated through or drained from hazardous waste.

Listed waste -- A solid waste characterized as hazardous because it has been place on one of three lists developed by the EPA: Non-specific source wastes; Specific source wastes; Commercial chemical products.

Low-level radioactive waste -- Waste that contains radioactivity and is not classified as high-level waste, transuranic waste, or spent nuclear fuel, or byproduct material.

Maximum Contaminant Level -- Represents the maximum permissible concentration of fourteen specific constituents in drinking water supplies as promulgated by the EPA under the SDWA.

Miscellaneous unit - A hazardous waste management unit where hazardous waste is treated, stored, or disposed of and that is not a container, tank, surface impoundment, pile, land treatment unit, landfill, incinerator, boiler, industrial furnace, underground injection well with appropriate technical standards under 40 CFR Part 146, or unit eligible for a research, development, and demonstration permit under $\$ 270.65$.

Open dump -- Any facility or site where solid waste is disposed of which is not a sanitary landfill which meets the criteria promulgated under Section 4004 and which is not a facility for disposal of hazardous waste.

Parial closure -- Closure of a hazardous waste management unit at a facility that contains other active hazardous waste management units.

Permit-by-rule -- A RCRA permit issued under the authorization of another statute (e.g., the Safe Drinking Water Act, the Clean Water Act, or the Marine Protection, Research, and Sanctuaries Act).

Pile -- Any non-containerized accumulation of solid, nonflowing hazardous waste that is used for treatment or storage.

Placement -- Also referred to as land disposal. For landfill closures, a facility must investigate whether closure activities constitute land disposal. Waste removed from a unit, treated, and placed back in to the unit, is considered land disposal and the waste is subject to the LDRs.

Plat (survey plat) -- A small piece of land; or a plan, map, or chart of a piece of land.

Pozzolonic materials - Cement kiln flyash or flyash from fossil fuel power plants, and other such materials; often used in combination with Portland cement as a stabilization technique.

Primacy - Exists in a State which has an approved UIC program. 
Replacement unit -- A unit that is taken out of service, cleared of waste, and then put back into service.

Settlement -- Uniformly distributed recession of a landfill due to compression of the foundation, liner, or waste or the dewatering of the waste. May primarily occur prior to cover construction.

Sanitary landfill -- A facility for the disposal of solid waste which meets the criteria published under Section 4004.

Sintering machine -- Type of pyrometallurgical device included in category of smelting, melting, and refining furnaces.

Sludge -- Any solid, semisolid or liquid waste generated from a municipal, commercial, or industrial wastewater treatment plant, water supply treatment plant, or air pollution control facility exclusive of the treated effluent from a wastewater treatment plant.

Slurry -- A watery mixture of insoluble matter.

Small quantity generator -- A generator who generates less than $1000 \mathrm{~kg}$ of hazardous waste in a calendar month.

Solid waste -- Any garbage, refuse, sludge, from a waste treatment plant, water supply treatment plant, or air pollution control facility and other discarded material, including solid, liquid, semisolid, or contained gaseous material resulting from industrial, commercial, mining, and agricultural operations, and from community activities, but does not include solid or dissolved material in domestic sewage, or solid or dissolved materials in inigation return flows or industrial discharges which are point sources subject to permits under section 402 of the Federal Water Pollution Control Act, as amended (86 Stat. 880), or source, special nuclear, or byproduct material as defined by the AEA of 1954, as amended (68 Stat. 923).

Source material -- Uranium, thorium, or any other material which is determined by the Atomic Energy Commission pursuant to the provisions of Section 61 of the AEA to be source material; or ores containing one or more of the foregoing materials, in such concentration as the AEC may by regulation determine from time to time.

Special nuclear material -- Plutonium, uranium enriched in the isotope 233 or 235 , and any other material which the AEC, pursuant to the provisions of Section 51 of the AEA, determines to be special nuclear material; or any material artificially enriched by any of the foregoing, but does not include source material.

Specific conductance - A measure of conductance per cubic centimeter which represents the ratio of current flowing through a cube (having sides of one centimeter) divided by the change in electrical potential from one side to the other side, assuming the current is flowing between opposite sides.

Speculative accumulation -- The accumulation of wastes that are potentially recyclable, but for which no feasible recycling market exists (i.e., recycling less than $75 \%$ of accumulated wastes during a one year period).

Storage -- (in connection with hazardous waste) -- The containment of hazardous waste, either on a temporary basis or for a period of years, in such a manner as not to constitute disposal of such hazardous waste.

Subsidence -- Unevenly distributed settlement after closure. May threaten the integrity of a cover by creating cracks and depressions. 
Surface impoundment -- A facility or part of a facility which is a natural topographic depression, manmade excavation, or diked area formed primarily of earthen materials, which is designed to hold an accumulation of liquid wastes or wastes containing free liquids, and which is not an injection well.

Tank -- A stationary device, designed to contain an accumulation of hazardous waste which is constructed primarily of non-earthen materials which provide structural support.

Tank system - A hazardous waste storage or treatment tank and its associated ancillary equipment and containment system.

Thermal treatment -- The treatment of hazardous waste in a device which uses elevated temperatures as the primary means to change the chemical, physical, or biological character or composition of the hazardous waste.

Transuranic waste -- Without regard to source or form, waste that is contaminated with alpha-emitting transuranium radionuclides with half-lives greater than 20 years and concentrations greater than $100 \mathrm{nCi} / \mathrm{g}$ at the time of assay.

Treatment -- (in connection with hazardous waste) -- Any method, technique, or process, including neutralization, designed to change the physical, chemical, or biological character or composition of any hazardous waste so as to neutralize such waste or so as to render such waste nonhazardous, safer for transport, amenable for recovery, amenable for storage, or reduced in volume. Includes any activity or processing designed to change the physical form or chemical composition of hazardous waste so as to render it nonhazardous.

T-Test protocol - Methodology governing the determination of concentrations of hazardous constituents in excess of background levels by statistically significant amounts. Applicable $T$-Tests pursuant to $40 \mathrm{CFR}$ $\$ 264.97$ are: parametric analysis of variance (ANOVA), analysis of variance based on ranks, tolerance or prediction interval, control chart approach, or other statistical test method approved by the Regional Administrator.

Underground injection -- The subsurface emplacement of fuids through a bored, drilled or driven well; or through a dug well, where the depth of the dug well is greater than the largest surface dimension.

Vadose zone -- (unsaturated zone) -. The zone of soil between the land surface and water table.

Wastewater treatment unit -- A device which: (1) Is part of a wastewater treatment facility which is subject to regulation under either Section 402 or Section 307(b) of the Clean Water Act; and (2) Receives and treats or stores an influent wastewater which is a hazardous waste as defined in $\$ 261.3$ of this chapter, or generates and accumulates a wastewater treatment sludge which is a hazardous waste as defined in $\$ 261.3$ of this chapter, or treats or stores a wastewater treatment sludge which is a hazardous waste as defined in $\$ 261.3$ of this chapter; and (3) Meets the definition of tank in 260.10 of this chapter.

Waterwall(s) -- Part of primary energy recovery section(s) of a boiler's combustion chamber. 


\begin{tabular}{|c|c|}
\hline $\mathrm{ACL}$ & Aiternate Concentration Limit \\
\hline $\mathrm{AEC}$ & Atomic Energy Commission \\
\hline ALARA & As Low As Reasonably Achievable \\
\hline ARAR & Applicable, Relevant and Appropriate Requirements \\
\hline ASTM & American Society for Testing Materials \\
\hline ATSDR & Agency for Toxic Substance \& Disease Registry [of the Center for Disease Control] \\
\hline BDAT & Best Demonstrated Available Technology \\
\hline BRC & Below Regulatory Concern \\
\hline CERCLA & Comprehensive Environmental Response, Compensation and Liability Act \\
\hline CFR & Code of Federal Regulations \\
\hline COCA & Consent Order/Compliance Agreement \\
\hline CPF & Carcinogenic Potency Factor \\
\hline $\mathrm{CQA}$ & Construction Quality Assurance \\
\hline $\operatorname{CSF}$ & Carcinogenic Slope Factor \\
\hline $\mathbb{E P}$ & Extraction Procedure \\
\hline FFCA & Federal Facility Compliance Agreement \\
\hline FML & Flexible Membrane Liner \\
\hline GWPS & Groundwater Protection Standard \\
\hline HELP & Hydrologic Evaluation of Landfill Performance model \\
\hline HSWA & Hazardous and Solid Waste Amendments of 1984 \\
\hline INEL & Idaho National Engineering Laboratory \\
\hline LDR & Land Disposal Restriction \\
\hline $\mathrm{LLW}$ & Low-Level Waste \\
\hline $\mathrm{MCL}$ & Maximum Contaminant Level \\
\hline mrem(year) & millirem/year (measure of radioactive activity) \\
\hline MTR & Minimum Technology Requirement \\
\hline NARM & Naturally-occurring or Accelerator-produced Radioactive Material \\
\hline $\mathrm{NCC}$ & National Computer Center \\
\hline NEPA & National Environmental Policy Act \\
\hline NRC & Nuclear Regulatory Commission \\
\hline NTIS & National Technical Information Service \\
\hline PNL & Pacific Northwest Laboratories \\
\hline RCRA & Resource Conservation and Recovery Act \\
\hline $\mathrm{RD}$ & Reference Dose \\
\hline SARA & Superfund Amendments and Reauthorization Act of 1986 \\
\hline SDWA & Safe Drinking Water Act \\
\hline SOC & Schedule of Compliance \\
\hline SQG & Small Quantity Generator \\
\hline SWMU & Solid Waste Management Unit \\
\hline TCLP & Toxicity Characteristic Leaching Procedure \\
\hline TSDF & Treatment, Storage, and Disposal Facility \\
\hline UIC & Underground Injection Control (program) \\
\hline USLE & Universal Soil Loss Equation \\
\hline UST & Underground Storage Tank \\
\hline WES & U.S. Army Corps of Engineers, Waterways Experiment Station \\
\hline WIPP & Waste Isolation Pilot Plant \\
\hline
\end{tabular}




\section{LIST OF EXHIBITS}

Exhibit

Number

\section{Overview of Hazardous and Radioactive Mixed Waste Management Requirements}

2-1 Loss of Interim Status Provisions . . . . . . . . . . . . . . . . . . . . 2-5

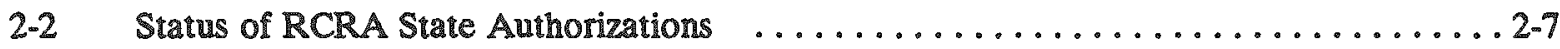

$2-3$ Primary DOE Facilities ................................. $2-8$

2-4 Requirements for TSDFs Handling Mixed Wastes ...................... 2-9

2-5 Determination of Whether a Recyclable Material is a Solid Waste Based on

Material Type and Recycling Activity ....................... 2-11

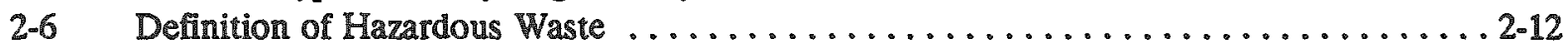

2-7 Toxicity Characteristic Constituents .......................... $2-14$

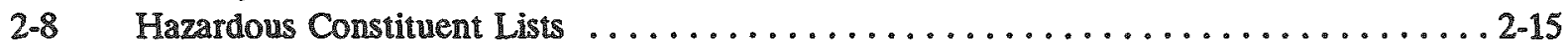

2-9 Standards that Apply to Particular DOE Waste Management Methods .......... 2-18

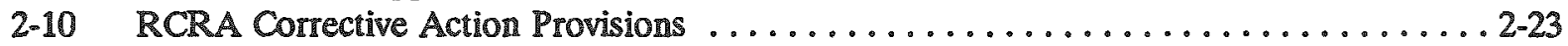

2-11 Surface Disposed Wastes Receiving Two-Year National Capacity Variance . . . . . . . 2-27

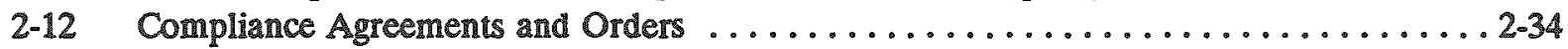

Procedural Requirements for Closing Hazardous and Mixed Waste Units

3-1 Summary of Subpart G Closure and Post-Closure Care Requirements . . . . . . . . 3-2

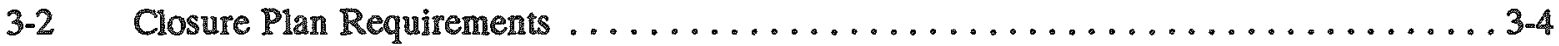

3-3 Notification of Closure . . . . . . . . . . . . . . . . . . . . . . . . . 3-9

3-4 Sample Format for Notification of Closure . . . . . . . . . . . . . . . . . 3-10

3-5 Sample Owner or Operator Closure Certification $\ldots \ldots \ldots \ldots \ldots \ldots \ldots \ldots \ldots \ldots$

3-6 Sample Independent Registered Professional Engineer Closure

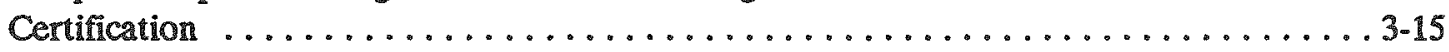

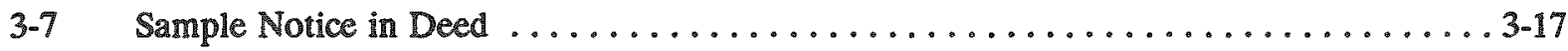

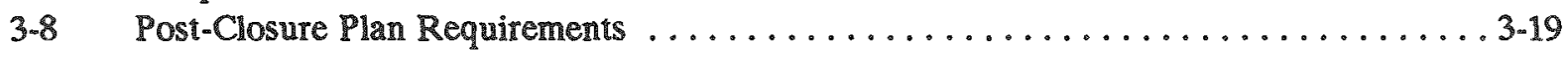

Technical Requirements for Closing Hazardous and Mixed Waste Units

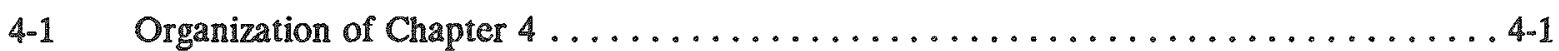

\section{Landfills}

4.1-1 Overview of Applicable Statutory and Regulatory Requirements $\ldots \ldots \ldots \ldots \ldots \ldots \ldots$. . . .

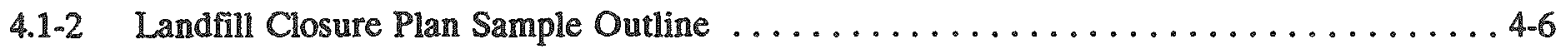

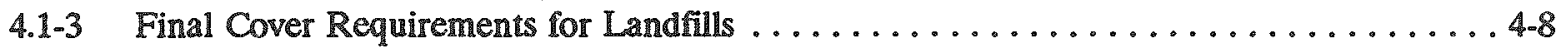

4.1-4 EPA's Recommended Three-Layer Cover System .................. . . 4-10

4.1-5 Alternative Design Requirements for Each Layer of a Final Cover . . . . . . . . . 4-13

4.1-6 Using the HELP Model to Demonstrate Infiltration Protection . . . . . . . . . . 4-14

4.1-7 Using the Universal Soil Loss Equation (USLE) to Estimate Erosion Potential . . . . . 4-15

4.1-8 Landfill Post-Closure Care Plan Sample Outline $\ldots \ldots \ldots \ldots \ldots \ldots \ldots \ldots \ldots \ldots . . \ldots \ldots$

4.1-9 Post-Closure Care Requirements for Landfills . . . . . . . . . . . . . . . . . . 4-22 
LIST OF EXHIBITS (Continued)

Exhibit

$\underline{\text { Number }}$

Surface Impoundments

$\underline{\text { Page }}$

4.2-1 Overview of Applicable Statutory and Regulatory Requirements . . . . . . . . . 4-27

4.2-2 Surface Impoundment Closure Options .......................... . 4-29

4.2-3 Assessing the Ability to Successfully Complete Clean Closure . . . . . . . . . . . . 4-32

4.2.4 Surface Impoundment Clean Closure Plan Sample Outline $\ldots \ldots \ldots \ldots \ldots \ldots \ldots \ldots . . . \ldots 44$

4.2-5 EPA Recommended Exposure Limits $\ldots \ldots \ldots \ldots \ldots \ldots \ldots \ldots \ldots \ldots \ldots \ldots \ldots \ldots$

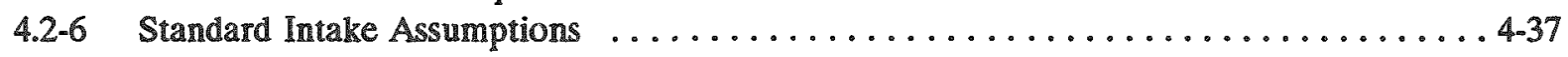

4.2 .7 How Clean is Clean? . . . . . . . . . . . . . . . . . . . . . . . . 4-41

4.2-8 Landill Closure Plan Sample Outline for Surface Impoundments . . . . . . . . . . 4-45

4.2-9 Landfill Closure Activities . . . . . . . . . . . . . . . . . . . . . . . . 4-48

4.2-10 EPA Recommended Final Cover Design ..................... 4-50

Waste Piles

4.3-1 Overview of Applicable Statutory and Regulatory Requirements . . . . . . . . . 4-55

4.3-2 Waste Pile Closure Procedures ............................ 4-56

4.3-3 Waste Pile Clean Closure Plan Sample Outline .................. . . 4-59

4.3-4 Waste Pile Contingent Closure Plan Sample Outline ... . . . . . . . . . . . . . . . . 4-62

4.3-5 Waste Pile Contingent Post-Closure Plan Sample Outline .............. 4-63

4.3-6 Landfill Closure Activities . . . . . . . . . . . . . . . . . . . . . 4-67

Land Treatment

4.4-1 Overview of Applicable Statutory and Regulatory Requirements ............ 4-71

4.4-2 Land Treatment Closure Plan Sample Outline ................... . . 4-75

4.4-3 Land Treatment Post-Closure Plan Sample Outline .................. 4-77

\section{Container Storage Areas}

4.5-1 Overview of Applicable Statutory and Regulatory Requirements $\ldots \ldots \ldots \ldots \ldots \ldots$

4.5-2 Closure of Container Storage Areas . . . . . . . . . . . . . . . . . . . . 4-84

4.5-3 Container Storage Closure Plan Sample Outline $\ldots \ldots \ldots \ldots \ldots \ldots \ldots \ldots \ldots \ldots$. . . . . . . .

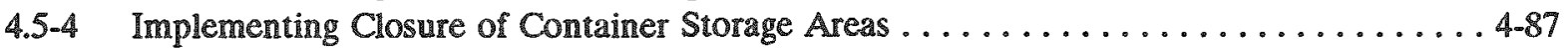




\section{LIST OF EXIIBITS (Continued)}

Exhibit

Number

Tranks

Page

4.6-1 Overview of Applicable Statutory and Regulatory Requirements . . . . . . . . . . . 4-92

4.6-2 Tank Closure Plan Sample Outline ............................. 4.95

4.6-3 Tank Contingent Closure Plan Sample Outline ... . . . . . . . . . . . . . . . 4-97

4.6.4 Tank Contingent Post-Closure Plan Sample Outlime ....................4.98

4.6-5 Decontamination Methods for Tanks and Other Facility Structures . . . . . . . . . . . 4-101

Incinerators

4.7-1 Overview of Applicable Statutory and Regulatory Requirements ............

$4.7-2$ Incinerator Closure Plan Sample Oulline ....................... $4-115$

\section{Miscellaneous Unî́s}

4.8-1 Examples of Units that are Included or Excluded from the Definition of Miscellaneous Unit .................................. 4-119

4.8-2 Overview of Applicable Statutory and Regulatory Requirements ............. 4-120

\section{Underground Injection Wells}

4.9-1 Overview of Applicable Statutory and Regulatory Requirements . . . . . . . . . 4.126

4.9-2 Underground Injection Well Closure Procedures ..................... 4-128 


\section{INTRODUCTION}

\subsection{PURPOSE OF THIS DOCUMENT}

In carrying out its national security missions, the U.S. Department of Energy (DOE) must generate and manage large volumes of hazardous and mixed radioactive wastes as part of its routine operations. Recognizing the potential environmental threat posed by these wastes, DOE and the U.S. Environmental Protection Agency (EPA) reached an agreement ${ }^{1}$ in February of 1984 which stipulated that DOE facilities that manage hazardous waste or hazardous components of radioactive mixed wastes must comply with all EPA regulations governing the generation and management of these wastes.

The requirement that DOE facilities comply with the Resource Conservation and Recovery Act (RCRA) was formalized on April 13, 1984, when the U.S. District Court of Tennessee ruled in LEAF v Hodel (586 F. Supp. 1163) that "RCRA requirements are not inconsistent with the Atomic Energy Act (AEA)." This ruling was reinforced in May of 1987, when DOE issued an interpretive rule clarifying that RCRA applied to the hazardous component of byproduct material ( 52 FR 15937), while the radioactive component was regulated under the AEA (10 CFR 962).

The RCRA Subtitle C regulations, found in Chapter 40 of the Code of Federal Regulations, Parts $260-272$, set "cradle-to-grave" standards for the generation, transport, treatment, storage, and disposal of hazardous wastes. Included among the many facility design and operating standards that must be specified in RCRA permits are strict closure and post-closure care requirements for hazardous or radioactive mixed waste management units. These standards are designed to protect human heaith and the environment from future releases of hazardous constituents.

This document is intended to provide guidance on how to comply with the RCRA Subtiqle C closure and post-closure care requirements at DOE facilities. It is intended for DOE Operations staff, DOE facility staff, and facility contractor staff responsible for compliance and oversight of RCRA hazardous and mixed waste compliance activities at the many DOE facilities located throughout the U.S.

\subsection{SCOPE OF THIS DOCUMENT}

This document addresses the Federal regulations governing the closure of hazardous and mixed waste units subject to RCRA requirements. It provides a brief overview of the RCRA perminting program and the extensive RCRA facility design and operating standards. It provides detailed guidance on the procedural requirements for closure and post-closure care of hazardous and mixed waste management units, including guidance on the preparation of closure and post-closure plans that must be submitted with facility permit applications. This document also provides guidance on technical activities that must be conducted both during and after closure of each of the following hazardous waste management units regulated under RCRA:

1 Environmental Protection Agency/Department of Energy Memorandum of Understanding on Responsibilities for Hazardous and Radioactive Mixed Waste Management, Signed February 22, 1984. 


$\begin{array}{ll}\text { - } & \text { Landfills } \\ \text { - } & \text { Waste piles } \\ \text { - Incineratoriner storage areas } \\ \text { Underground injection wells }\end{array}$

- Surface impoundments

- Land treatment units

- Tanks

- Miscellaneous units

- Thermal treatment units

- Chemical, physical, and biological treatment

While this document provides significant detail on the regulatory requirements governing closure as well as presenting the technical activities that must be conducted at closure, it should not be viewed as a "cookbook" that includes all relevant information necessary for conducting closures. Closing hazardous waste management units is an extremely complex undertaking that will involve considerable interaction among DOE Operations Offices and facilities, EPA Regions, and States. No single document can contain all the information relevant to closure of hazardous waste management facilities, especially those containing radioactive mixed wastes. Accordingly, this document includes a comprehensive set of references in each section that will direct the reader to additional detailed guidance on various aspects of closure. This document should therefore be viewed as a general reference for guidance on RCRA closures at DOE facilities, but not as the only reference needed for conducting RCRA closures. Additional guidance can be found in "Guidance on Stabilization and Closure of U.S. DOE Mixed and Low Level Radioactive Waste Disposal Facilities," DOE/LLW-82, June 1990.

This document does not address the integration of RCRA and National Environmental Policy Act (NEPA) compliance; however, when applicable, owners or operators of DOE facilities should consider coordinating data collection efforts required for closure and post-closure care plans under RCRA to facilitate compliance with NEPA. In addition, this manual does not address closures and cleanups under CERCLA; however, to the extent that RCRA requirements are considered applicable or relevant, and appropriate requirements (ARARs), this manual may be a useful reference.

Under RCRA, States may be authorized for implementing RCRA Subtitle C upon demonstrating that they have promulgated State regulations that are no less stringent than the Federal standards. To date, many States have been authorized to implement the "base" RCRA program (see Chapter 2 Exhibit 2-2). In "authorized States," the State standards supersede the Federal regulations. In "unauthorized States," the Federal standards are implemented by the EPA Regional Office; any other State standards pertaining to hazardous waste may also be applicable at DOE facilities. It is important to note that States must apply separately for authorization to regulate mixed wastes and to implement the requirements established under the Hazardous and Solid Waste Amendments (HSWA) of 1984 (e.g, corrective action). Depending upon the authorization status of a State, regulation of mixed wastes may involve several regulatory authorities or may not yet be regulated at all under RCRA (see Section 2.1.1.2).

In this document, references to the "Regional Administrator" can be replaced by "State Director" for States with RCRA Subtitle C authorization. This document does not address individual State standards pertaining to RCRA closure activities. While most State standards are quite similar to the RCRA regulations found in 40 CFR Parts $260-270$, it is important that persons using this guidance consult all applicable State regulations in authorized States. 
This document is organized into three sections following this introduction.

- Chapter 2 provides an overview of the requirements pertaining to the management of hazardous and radioactive mixed wastes. It focuses on those general RCRA requirements that must be understood as background for the RCRA closure program, found in 40 CFR Parts 261, 262, 264, 265, 268, and 270. It provides an overview of the Atomic Energy Act and a number of applicable DOE Orders. Finally, it discusses the differences in authority for managing mixed wastes that result from a State's RCRA authorization status.

- Chapter 3 outlines the procedural requirements for closing hazardous and mixed waste units. This section focuses on the general closure and post-closure care requirements found in Subpart G of 40 CFR Parts 264 and 265, which present the general closure performance standard, requirements for preparing closure and post-closure plans, and schedules for conducting closure activities.

- Chapter 4 presents technical guidance on closing hazardous and mixed waste management units. It is divided into the following nine separate sections:

$\begin{array}{lll}\text {-- } & 4.1 & \text { Landfills } \\ \text {-- } & 4.2 & \text { Surface impoundments } \\ \text {-- } & 4.3 & \text { Waste piles } \\ \text {-- } & 4.4 & \text { Land treatment units } \\ \text {-- } & 4.5 & \text { Container storage areas } \\ \text {-- } & 4.6 & \text { Tanks } \\ \text {-- } & 4.7 & \text { Incinerators } \\ \text {-- } & 4.8 & \text { Miscellaneous units } \\ \text {-- } & 4.9 & \text { Underground injection wells }\end{array}$

Whenever appropriate, each chapter also contains a list of references for additional information. 
REFERENCES: CHAPTER 1

"Guidance on Stabilization and Closure of U.S. DOE Mixed and Low Level Radioactive Waste Disposal Facilities," DOE/LLW-82, June 1990. 


\section{OVERVIEW OF HAZARDOUS AND RADIOACTIVE MLXED WASTE MANAGEMENT REQUIREMENTS}

This chapter presents a general overview of the statutes, regulations, and policies governing the management of hazardous and radioactive mixed wastes at DOE facilities. This chapter discusses the requirements established by EPA pursuant to RCRA, the requirements established by DOE pursuant to the Atomic Energy Act of 1954 as amended, and various DOE Orders that affect closures of DOE facilities. It provides an overview of those aspects of the RCRA program especially relevant to the closure of hazardous waste management units. In addition, it outlines the procedures for determining whether a waste is a hazardous waste or a radioactive mixed waste.

\subsection{RESOURCE CONSERITION AND RECOVERY ACT (RCRA)}

Subtitle C of RCRA establishes standards for generators and transporters of hazarcous wastes and for owners and operators of hazardous waste treatment, storage, and disposal facilities. Through the RCRA regulations, EPA regulates hazardous waste from the time it is generated until its ultimate disposal. RCRA was originally signed into law on October 21, 1976 [Public Law 94-580] and has since been reauthorized twice. The most extensive changes to the original Act were those enacted in 1984 under the Hazardous and Solid Waste Amendments (HSWA). These amendments included new requirements for land disposal restrictions, underground storage tanis, surface impoundments, corrective action, and permitting deadlines.

RCRA, as amended by HSWA, is divided into ten subtilles.

- Subtitle $A-$ - Genercl Provisions. Contains Congressional findings related to solid waste, defines the objectives of RCRA, and describes integration between RCRA and other statutes.

- Subtitle $B=$ Office of Solid Waste; Authorities of the Administrutor. Establishes the Office of Solid Waste and defines the responsibilities of the Administrator.

- Subtitle C- Hazardous Woste Management. Establishes a management system that regulates hazardous waste from the time it is generated until its ultimate disposal.

- Subtitle D - State or Regional Solid Wasce Plans. Establishes a Federal program to promote the environmentally sound disposal of solid waste (i.e., wastes not defined as hazardous j.

- Subtutle E - Duties of the Secretary of Commerce in Resource and Recovery. Requires the Secretary of Commerce to encourage greater commercialization of proven resource recovery technologies.

- Subtidle F - Federal Responsibilities. Stipulates that Federal facilities shall be subject to all applicable RCRA requirements. 
- Subtitle $G=$ Miscellameous Provisions. Establishes standards and procedures for employee protection, citizen suits, imminent hazard protection, public participation, judicial review, etc. related to RCRA.

- Subtitle $\mathbb{H}-$ Research, Development, Demonstration, and Information. Encourages special studies, new programs, and innovative technologies, and provides for coordination, collection, and dissemination of information related to solid waste.

- Subtitle I- Regulation of Underground Storage Tanks. Regulates petroleum products and hazardous substances (as defined by CERCLA) stored in underground storage tanks.

- Subtitle J - Medical Wastes. Establishes a two-year demonstration program for tracking medical waste in participating States.

Under RCRA, EPA has the authority to promulgate regulations as necessary to protect human health and the environment. EPA promulgated hazardous waste regulations, which carry the force of law, in the following Parts of Chapter 40 of the Code of Federal Regulations (CFR):

- 40 CFR Part 261: Definition of Hazardous Woste

- 40 CFR Part 262: Generator Standards

- 40 CFR Part 263: Transporter Standards

- 40 CFR Part 264: Standards for Permitted Units

- 40 CFR Part 265: Standards for Interim Status Uriels

- $\quad 40$ CFR Part 266: Standards for Specific Hazardous Wastes and Facilities

- $\quad 40$ CFR Part 267: Standards for New Land Disposel Units (Superseded by Part 264)

- $\quad$ 40 CFR Part 268: Land Disposal Restrictions

- 40 CFR Purt 270: Permit Program

Chapter 2 of this guidance document focuses on the $R C R A$ Subtitle $C$ regulations for identification, treatment, storage, and disposal of hazardous waste. In particular, it addresses the general requirements governing treatment, storage, and disposal facilities handling hazardous and radioactive mixed wastes that are relevant to DOE facilities. The rest of the document focuses on the closure and post-closure care requirements found in this regulatory program.

\subsection{The RCRA Permitting Program (40 CFR Part 270)}

Who Must Heve a Permit? All facilities that treat, store, or dispose of hazardous or mixed wastes are required to obtain a RCRA permit (Section 2.1.2 discusses how to determine if a waste is a hazardous waste and thus subject to a permit). There are, however, several exclusions to this requirement. These include (40 CFR $\$ 270.1(c))$ :

- Generators who store waste on-site in tanks or containers for less than 90 days;

- Farmers who dispose of their own pesticides on-site; 
- Small quantity generators;

- Owners or operators of totally enclosed treatment facilities;

- Owners or operators of wastewater treatment units (tanks) and elementary neutralization units (tanks or containers);

- Transporters who store manifested wastes at a transfer facility for less than 10 days;

- Persons combining waste and absorbent material in a container, provided that this combination occurs at the time the waste is first placed in the container; or

- Owners or operators of solid waste (i.e., non-hazardous) disposal facilities that only handle small quantity generator waste (e.g., municipal solid waste landfills).

Types of Permits. EPA issues several different types of permits for hazardous waste management.

- Treatment, storage, or disposal permits are the standard form of permit required for most hazardous waste management facilities. These permits include the administrative and technical performance standards (including closure and post-closure requirements) that a hazardous waste management facility must meet. The permit also serves as the basis for any enforcement actions deemed necessary by EPA to bring a facility that is not complying with these standards into compliance.

- Research, development, and demonstration (RD\&D) permits are issued by EPA to encourage the use of alternative treatment technologies. To be eligible for a RD\&D permit, national standards must not exist for the experimental treatment technology. Permits are issued for one year, although they may be renewed up to three times. RD\&D facilities can only receive wastes that are necessary to determine the efficacy of the treatment technology.

- Post-closure permits are issued to facilities closing with wastes in place. These permits specify the post-closure care responsibilities of the facility, including ground-water monitoring requirements, corrective action (if appropriate), and other maintenance activities as necessary. The permit also serves as the basis for any enforcement actions deemed necessary by EPA to bring a facility that is not complying with these standards into compliance.

- Permits-by-rule are provided by EPA when a facility must be permitted both under RCRA and another statute with similar permitting regulations. The goal of a permit-by-rule is to avoid duplication and streamline the permit application process. Certain facilities with permits under the Safe Drinking Water Act, Clean Water Act, or Marine Protection, Research, and 
Sanctuaries $A c t$, need only meet selected Subtitle $C$ requirements in addition to those for which they are already in compliance, in order to receive a RCRA permit-by-rule. Examples of such facilities include underground injection wells and ocean dumping barges.

Emergency permits are issued to a non-permitted facility, or to a permitted facility for hazardous waste activities not covered under the existing permit in the event there is an imminent and substantial endangerment of human health or the environment." An emergency permit is typically issued for a period of 90 days or less.

Trial bum and land treatment demonstration permits are issued to new incinerator and land treatment units respectively. The purpose of these permits is to allow these facilities to demonstrate their ability to perform up to operating standards. Once the demonstration period is complete, owners or operators of these facilities can apply for a final RCRA permit.

\subsubsection{Permit Applicutions}

Imerime Status. Although RCRA requires treatment, storage, and disposal facilities to operate under the conditions of a permit, Congress recognized that it would take many years for EPA to issue all of the necessary permits. Thus Congress established interim status under Section $3005(\mathrm{e})$ of RCRA, which allows owners or operators of facilities in existence on November 19, 1980 (or brought under Subtitle C due to an amendment), who meet certain conditions, to continue operating under interim status until a final permit application is approved or denied.

Eligible facilities were granted interim status as long as they submitted a Part A application by November 19, 1980. Part A of the application is a short standard form that collects general information about the facility, the wastes handied, and the waste management activities conducted at the facility. These facilities are subject to the RCRA interim status standards (40 CFR Part 265) unil a Part B application is filed and a final decision on a permit has been made. Disposal racilities that close prior to receiving a RCRA permit must comply with interim status post-closure requirements until their post-closure permit is issued. DOE facilities with units containing radioactive mixed wastes became subject to the interim status requirements of 40 CFR Part 265 upon promulgation of the May 1, 1987, byproduct nule, and had to submit Part A of their pernit application by November 1, 1987 (40 CFR 270.10(e)).

The second part of the permit application -. the Part B -- provides detailed facility information, including the closure plans, and if appropriate, posi-closure plans, for all hazardous waste management units at the facility. Closure and post-closure plans, once submitted, become a part of the permit. Existing facilities with interim status must submit the Part B either when requested by EPA or a State Agency or on the date mandated by RCRA (see Exhibit 2-1), whichever is earlier. If the Part B applications are not submitted by the following deadlines, the facility loses interim status and therefore must close. 
Exhàndit 2-1

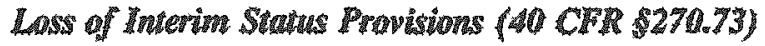

\begin{tabular}{|c|}
\hline 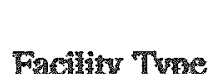 \\
\hline
\end{tabular}

\begin{tabular}{|c|c|c|}
\hline Misposal & November 8, 1985 & November 1985 \\
\hline Incinerator & Novenber 8,1986 & November 8,1989 \\
\hline All other acinzides & November 8,1988 & Wovember 8,1992 \\
\hline
\end{tabular}

Interim status regulated units (landfills, surface impoundments, waste piles, and land treatment units receiving waste after July 26, 1982) must submit additional information in their Part B applications. These additional information requirements are located in $40 \mathrm{CFR} \$ 270.14$ (c) and include a detailed description of the ground-water monitoring system, complete characterizations of any plumes of contamination, and the development of a corrective action plan in the event such a plume is detected.

Parts $A$ and $B$ of the permit application must be submitted at least 180 days before construction of any new facility. In most cases there is no standard form to follow for preparing the Part $B$ application, so owners or operators of hazardous waste management units should rely on 40 CFR Parts 264 and 270 for guidance. In addition, EPA has provided listings and general descriptions of what must be included in a Part B application in EPA 530-SW-84-004, "Permit Applicants' Guidance Manual for Hazardous Waste Land Treatment, Storage, and Disposal Facilities, Final Draft," Moy 1984.

If a permit application is not complete, a Notice of Deficiency Letter that describes the missing information is sent to the owner or operator. Once a completed permit application (both Parts $A$ and $B$ ) is submitted by the owner or operator of a facility, the permit is reviewed, and either approved or denied by the EPA. Regional Administrator. In practice, the administrative review portion of the permit application process may involve several iterations of submission, review, comment, resubmission, etc.

If a facility submitted a Part B permit application to EPA before November 8, 1984, EPA is required to either approve or deny the application in accordance with the following schedule set out under HSWA:

- Land Disposal Facilities by November 8, 1988

- Incinerators by November 8, 1989

- All other TSDFs by November 8, 1992. 
HSWA did not place any time limitations on EPA for the review of permit applications submitted after November 8,1984 . The duration of the permit review period is dependent upon the type of permit and the Region in which it is reviewed. In general, a facility should expect that the evaluation of its permit application will take from 1 to 3 years. If a permit is reviewed and denied, EPA sends the owner or operator a Notice of Intent to Deny. The owner or operator may appeal this decision to the EPA.

After a permit application is approved, EPA prepares a draft permit. The draft permit incorporates applicable technical requirements and other conditions pertaining to the operation of the facility. EPA must then give public notice and allow 45 days for written comments. After the comment period expires, the Regional Administrator issues a final permit decision. This decision is binding, but may be appealed in the U.S. Court of Appeals.

Periodically, all hazardous waste management facilities are inspected. If compliance problems are uncovered during these inspections, EPA may modify the conditions of a permit, revoke and reissue a permit, or terminate a permit. Termination of a permit occurs because of either facility non-compliance with the terms of the permit, failure on the part of the permittee to disclose relevant information, or the permitted activity endangers human health or the environment and can only be regulated to acceptable levels by terminating operations.

\subsubsection{Stote Authorizadion}

RCRA Section 3006(b) allows States to apply to EPA for authorization to administer and enforce a hazardous waste program pursuant to Subtitle $C$. Authorized State programs are carried out in lieu of the Federal program. Forty-three States and one U.S. territory are authorized for the base RCRA program (see Exhibit 2-2). It should be noted, however, that approved State programs are not static; EPA may initiate the revision of a State's program, withdraw its approval, or transfer a State's responsibilities back to the Federal government when necessary. For example, HSWA made many changes to the RCRA program. For this reason, the Federal government enforces HSWA requirements in States that are authorized only for the base RCRA program until these States receive HSWA authorization.

On July 3, 1986, EPA promulgated a rule that required States authorized for base RCRA to revise their programs to demonstrate the capability to regulate the hazardous components of radioactive mixed wastes. The deadline for compliance with this rule was July 3, 1987 (or July 5, 1988 for States requiring statutory amendments). States applying for base RCRA authorization after July 3, 1986 had to apply for mixed waste authorization at the same time (40 CFR 271.3(f)). As of May 30, 1990, only nineteen States and one territory have received mixed waste authorization (see Exhibit 2-2).

The incomplete authorization of State programs has led to a confusing mosaic of regulatory authority and has created some regulatory "loopholes" as well. Facilities in States without base RCRA authorization are subject to Federal RCRA and radioactive mixed waste requirements. Such facilities are also subject to State requirements, if any exist. However, in States with base RCRA athorization wad without radiocctive mixed waste authorization, mixed waste is mot defined as hazardous waste, and thus the hazardous component is not regulated unuler RCRA. Note that the huzardous component could be subject to State regullutions (51 FR 24504). In addition, after September 25,1990 , mixed waste that exhibits the toxicity characteristic is always defined as hazardous waste, regardless of the authorization status of a State. This is because mixed waste containing toxicity characteristic constituents is regulated under HSWA, and thus the EPA Regions are responsible for implementing all requirements pertaining to such waste (see Section 2.1.2.1 for a discussion of the toxicity 
characteristic). In States that are authorized for both base RCRA and mixed waste, facilities are subject only to State regulations. Because HSWA and mixed waste are completely separate programs, a State's mixed waste authorization status is totally independent and unaffected by its HSWA authorization status.

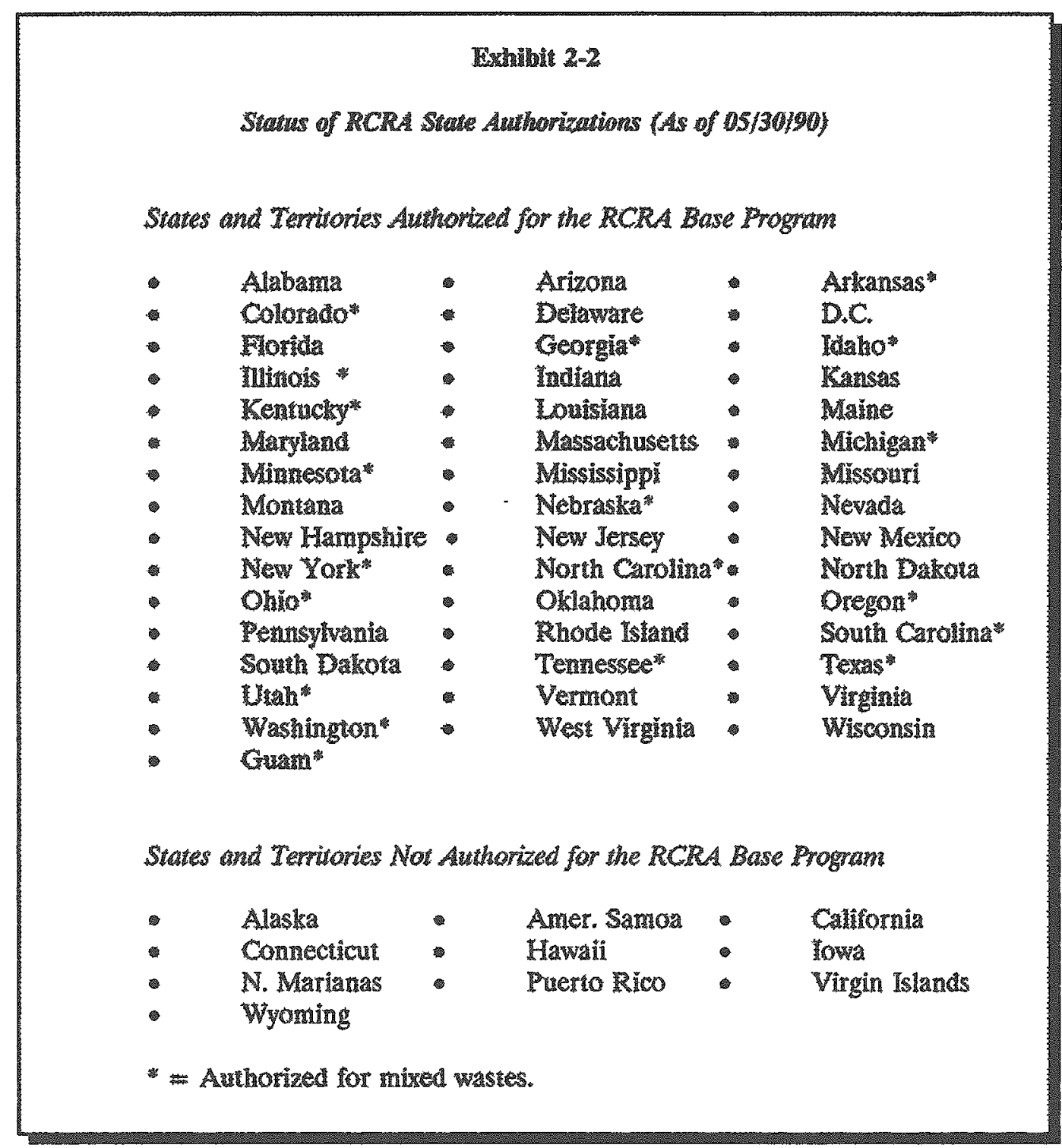

Note that 11 of DOE's 18 primary facilities are located in States with mixed waste authorization, and thus the hazardous components of any radioactive mixed waste located at these facilities are subject to RCRA requirements as administered by the State (see Exhibit $2-3$ below). 


\section{Primary DOE Facilities}

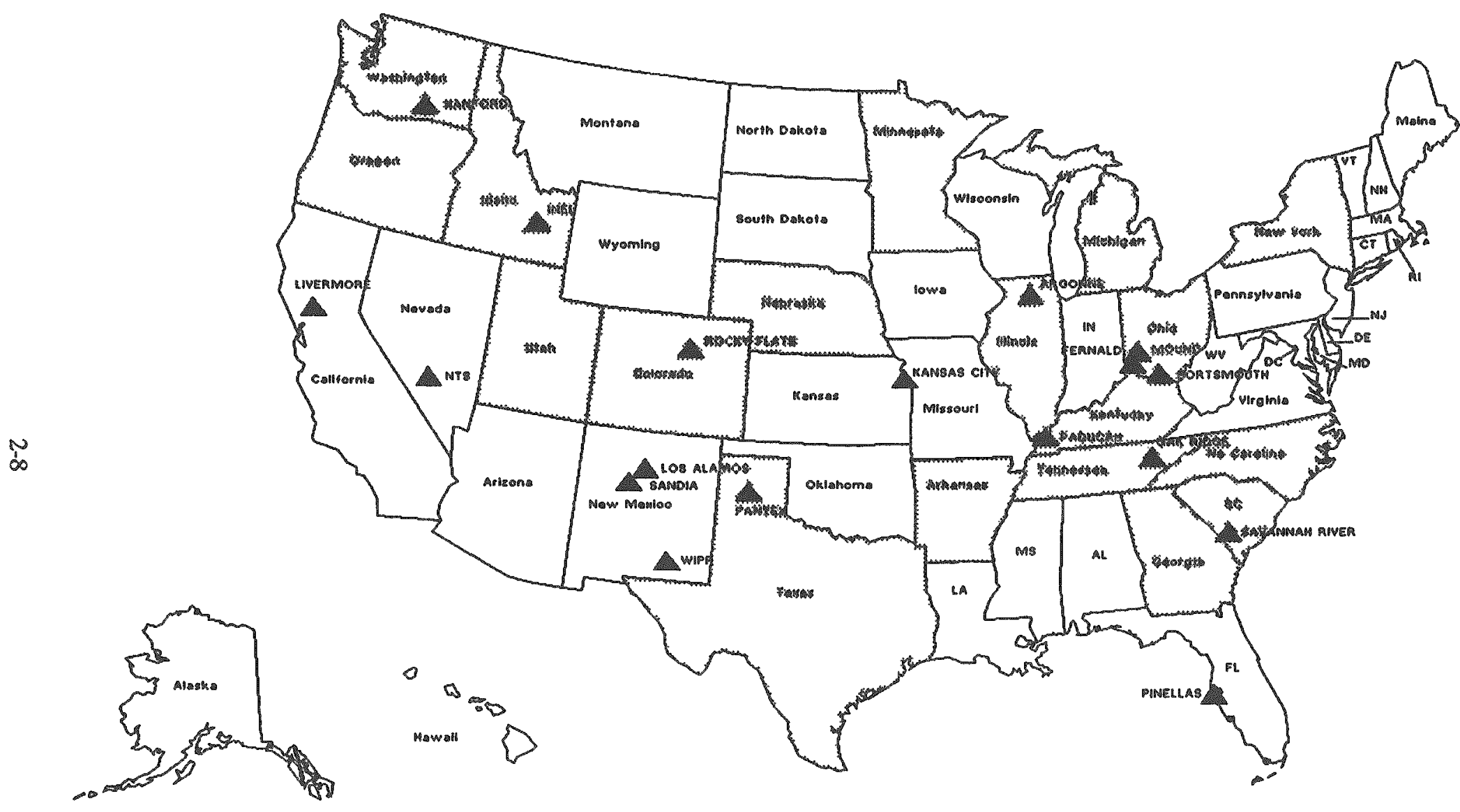

States Authorized for Mixed Waste

4 Primary DOE Facility 
Exhibit $2-4$ below summarizes the requirements for interim status and permitted facilities that handle radioactive mixed wastes according to the authorization status of the State in which they are located.

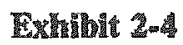

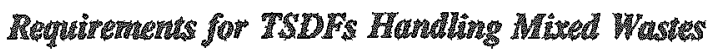

Facility Located in:

Applicable Requirements

State not anthorized for base RCRA program or mixed waste.

State authoriged for base RCRA prograran but not for mixed waste.

State authorized for both base RCRA program and mixed waste.
Mined wastes atre subject to Federal RCRA Subtatle C requirements and RCRA pertuit conditions. State may atso have gdâtional requatiements.

RCRA Subitile C requirements do not apply to mixed wastes. State may have requirements.

Mixed waster are subject to State RCRA permatitum requirements.

\subsubsection{Idensification and Listing of Hazardous Wastes (4OC CFR Part 261)}

The regulations defining solid and hazardous wastes are found in 40 CFR Part 261. Determining whether or not a waste is hazardous is complex. However, it is crucial for determining whether it is subject to Subtitle $C$ and whether the facility handling the waste is subject to a RCRA permit. Under RCRA, it is the responsibility of the facility owner or operator to determine whether a waste is hazardous. The following sections provide guidance on how to determine whether a waste stream is hazardous and whether it is considered a radioactive mixed waste. Also included in this section is a discussion of procedures for "delisting" as waste stream in order to exclude in from regulation under RCRA Subtitle C. These issues will be critical when determining how to dispose wastes excavated during closure or contaminated media (e.g., ground water) removed as a part of closure or corrective action.

\subsubsection{Defineidion of Solid Wustes}

Under RCRA, hazardous wastes are defined as a subset of solid wastes; therefore, unless waste is first a solid waste, it cannot be a hazardous waste. Solid wastes are defined in 40 CFR \$261.1 as any material that is disposed of, burned or incinerated, recycled, or "considered inherently waste-like," regardless of whether it is a solid, semi-solid, or liquid. The terms "recycled" and "inherently waste-like" can both be interpreted widely, and depending on the interpretation, will determine whether or not wastes will be subject to RCRA regulations. 
Inherently Woste-Like. EPA designated six categories of waste (located in 40 CFR $\$ 261.2(d)$ ) to be "inherently waste-like" and thus also classified as "solid wastes" when recycled in any manner. These wastes (FO20-FO23, FO26, and FO28) are not likely to be generated at many DOE facilities because they are derived from the formulation and production of pesticides.

Recyclable Muterials. EPA has determined that the following information should be used to determine whether a recyclable material is a solid waste and therefore subject to RCRA:

- The nature of the material; and

- The manner in which it will be recycled.

Exhibit $2-5$ below illustrates conditions under which a recyclable material will be considered a solid waste. If a material is not classified as a solid waste, then it is not be subject to Subtitle $C$ as a hazardous waste.

Exceptions. $40 \mathrm{CFR}$ \$261.4(a) lists materials that are not considered solid wastes regardless of whether they fit the definition given above (i.e., material that is disposed of, burned or incinerated, recycled or considered inherently waste-like). Examples of exceptions include domestic sewage, irrigation return flows, and source ${ }^{2}$, special nuclear ${ }^{3}$ and byproduct materials ${ }^{4}$ as defined by the Atomic Energy Act. The exception for source, special nuclear, and byproduct material applies only to the radioactive portion of the wastes and will be discussed in section 2.1.2.6.

2 Source material is defined jointly by EPA and the Nuclear Regulatory Commission (NRC) as "(1) uranium, thorium, or any other material which is determined by the Atomic Energy Commission pursuant to the provisions of section 61 of the AEA to be source material, or (2) ores containing one or more of the foregoing materials, in such concentration as the AEC may by regulation determine from time to time" ( 52 FR 11147).

3 Special nuclear material is defined jointly by EPA and NRC as "(1) plutonium, uranium enriched in the isotope 233 or in the isotope 235, and any other material which the AEC, pursuant to the provisions of Section 51 of the AEA, determines to be special nuclear material; or (2) any material artificially enriched by any of the foregoing, but does not include source material" (52 FR 11147).

4 Byproduct materials are defined jointly by EPA and NRC as "(1) any radioactive material (except special nuclear material) yielded in or made radioactive by exposure to radiation incident to the process of producing or utilizing special nuclear material, and (2) the tailings or wastes produced by the extraction or concentration of uranium or thorium from any ore processed primarily for its source material content" (52 FR 11147). 


\section{Exhaibit 2.5}

\section{DETERMINATION OF WHETHER A RECYCLABLE MATERIAL IS A SOLID WASTE BASED ON MATERIAL TYPE AND RECYCLING ACTIVITY [Yes = defined as a solid waste; No = not defined as a solid waste]}

\begin{tabular}{|c|c|c|c|c|}
\hline Material & $\begin{array}{l}\text { Use } \\
\text { Constituting } \\
\text { Disposal a/ }\end{array}$ & $\begin{array}{l}\text { Buming for Energy } \\
\text { Recovery or Use to } \\
\text { Produce a Fuel }\end{array}$ & Reciamation b/ & $\begin{array}{l}\text { Speculative } \\
\text { Accumulation of }\end{array}$ \\
\hline $\begin{array}{l}\text { Spent Materials d/ } \\
\text { (both listed \& non- } \\
\text { listed/characteristic) }\end{array}$ & Yes & Yes & Yes & Yes \\
\hline $\begin{array}{l}\text { Sludges } \\
\text { (listed in } 40 \text { CFR } \$ \$ 261.31 \\
\text { or } 261.32 \text { ) }\end{array}$ & Yes & Yes & Yes & Yes \\
\hline $\begin{array}{l}\text { Sludges } \\
\text { (nonlisted/characteristic) }\end{array}$ & Yes & Yes & No & Yes \\
\hline $\begin{array}{l}\text { Byproducts el } \\
\text { (listed in } 40 \text { CFR } \$ \$ 261.31 \\
\text { or } 261.32 \text { ) }\end{array}$ & Ye & Yes & Yes & Yes \\
\hline $\begin{array}{l}\text { Byproducts e/ } \\
\text { (nonlisted/characteristic) }\end{array}$ & Yes & Yes & No & Yes \\
\hline $\begin{array}{l}\text { Commercial chemical products } \\
\text { (listed in } 40 \text { CFR } \$ 261.33 \text { but } \\
\text { not applied to land or burned } \\
\text { as fuel) }\end{array}$ & Yes & Yes & No & No \\
\hline Scrap Metal & Yes & Yes & Yes & Yes \\
\hline
\end{tabular}

a/ Use constituting disposal is the direct placement of wastes (or products that contain wastes as an ingredient) onto the land.

b/ Reclamation is waste regeneration or the recovery of material from wastes, but does not include use or reuse of the waste withou preprocessing) as an ingredient in a manufacturing process.

cf Speculative accumulation is the accumulation of potentially recyclable wastes for which no feasible market exists (i.e., recycling less than 75 percent of accumulated wastes during a one year period).

d) Chemical, not nuclear, spent materials.

ef Chemical, not nuclear, byproducts.

Source: $\quad 40 \mathrm{CFR}$ \$261.2, Table I. 
Exhibis 2-6

\section{Definition of Howarions Wrate (40 CFI \$261.3)}

To determine whether a solid waste guatifies as hazardous waste, consider the following guestions:

- Does the waste exhibit any one of the four characteristics of a lazardous waste identified in to CFR Part 261 Subpar C?

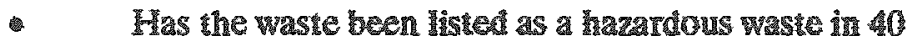
CrR Par 261 Subpar D?

- Us the vaste a minure comaining a listed hazardous waste and a non-hazardous solid waste?

- Is the waste derived yom the treatment of a listed hazardous waste?

- Is the waste not excluded from regulation as hazardous waste?

- Is the waske hazardous vast containedin an environmental medium such ground water or soill?

If the answer is yes to any one of the preceding questions, the solid waste is a hazardous waste.

Characteristic Wastes. EPA identified four characteristics of hazardous wastes in Part 261 Subpar $C$ : ignitability, corrosivity, reactivity, and toxicity. To determine if a solid waste is a characteristic waste, compare its properties with those listed in the regulations. Although generators are required to determine whether or not their solid wastes are hazardous, they are not specifically required to perform any tests on their wastes; instead they may rely on their knowledge of the materials and processes used in generating the wastes. The following is a brief description of the four characteristics of hazardous wastes:

- Ignitability (40 CFR \$261.21). A solid waste is considered ignitable if it has the following properties: it is a liquid, except an aqueous solution containing less than 24 percent alcohol, that has a flash point of less than $60^{\circ} \mathrm{C}\left(140^{\circ} \mathrm{F}\right)$; it is a non-liquid capable, under normal circumstances, of spontaneous and sustained combustion; or it is an ignitable compressed gas or an oxidizer per Department of Transportation (DOT) regulation. 
- Corrosivity (40 CFR \$261.22). A solid waste is considered corrosive if it is an aqueous material with a pH less than or equal to 2.0 or greater than or equal to 12.5 , or if it is a liquid that corrodes steel at a rate greater than $1 / 4$ inch per year at $55^{\circ} \mathrm{C}$ $\left(130^{\circ} \mathrm{F}\right)$.

- Reactivity (40 CFR \$261.23). A solid waste is considered reactive if it has the following properties: it is normally unstable and reacts violently without detonating; it reacts violently, forms an explosive mixture, or generates toxic gases, vapors, or fumes when mixed with water; it contains cyanide or sulfide and generates toxic gases, vapors, or fumes at a $\mathrm{pH}$ of between 2.0 and 12.5 ; it is capable of detonation if heated under confinement, subjected to strong initiating force, or at standard temperature and pressure; it or is listed as a DOT Class A or B explosive.

-

Toxicity (40 CFR \$261.24). A solid waste exhibits the toxicity characteristic (TC) if after conducting the Toxicity Characteristic Leaching Procedure (TCLP) test described in detail in $40 \mathrm{CFR}$ Part 261 Appendix II, the extract from the waste contains any of the 39 hazardous constituents listed in Table I of 40 CFR $\$ 261.24$ at a concentration level equal to or greater than is specified in the same table.

On March 29, 1990 the EPA adopted a rule that replaced the Extraction Procedure (EP) with the TCLP and expanded the list of toxic constituents from 14 to 39 . This new rule (51 FR 21648) has a major impact on whether a solid waste is designated as a hazardous waste. This rule significantly increases the amount of wastes DOE facilities must handle as hazardous or radioactive mixed wastes. Exhibit 2-7 below presents the 14 original constituents covered and the 25 additional constituents now covered under the TC rule. Because revision of the EP toxicity standard was a HSWA requirement (Section $3001(\mathrm{~g})$ ), mixed waste exhibiting the toxicity characteristic is considered HSWA regulated. Therefore, after September 25,1990 , a State's authorization status does not affect the definition of TC-contaminated mized waste; it is always considered a hazardous waste.

Listed Wustes. Any solid waste listed in Subpart D of 40 CFR Par 261 is considered hazardous. There are four separate lists of hazardous wastes:

- Wastes from non-specific sources (40 CFR \$261.31) -- identified as "F" wastes. These wastes include many solvent wastes (F001 - F005) generated at DOE facilities that may be mixed radioactive wastes.

- Wastes from specific sources (40 CFR \$261.32) -- this listing identifies individual waste streams from specified industrial processes. These wastes are frequently referred to as " $\mathrm{K}$ " wastes.

- Discarded and off-specification commercial chemical products and residues from these products identified as acutely hazardous (40 CFR \$261.33(e)) -referred to as "P" wastes.

- Discarded and off-specification commercial chemical products and residues from these products identified as toxic (40 CFR \$261.33(I)(6)) -- referred to as "U" wastes. 


\section{Fxhilbie 2-7}

\section{Toxiciry Characterisuic Constizuents}

Constituents under the Extraction Procedure rule:

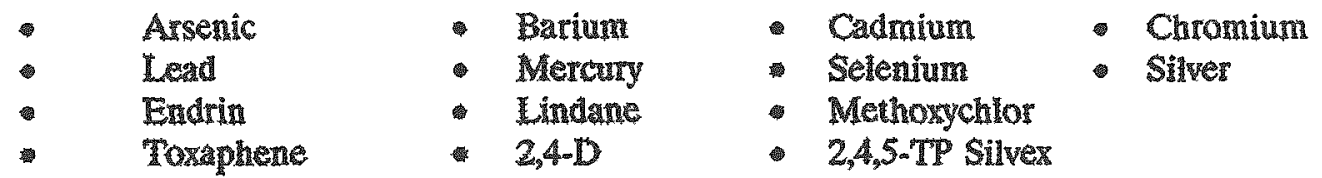

Additional constituents under the Toxicity Characteristic ru?e:
- Benene
- Chofobenzene
- m-Cresol
- 2 Dichlorocthane
- Ieptachior
- Hexachorocthane
- Prachorophenot
- Trichloroethylene
Visy coloride

- Carbon Tetrachloride

- Chloroform

- p-Cresol

- Ir Dichlorochylene

- Hezachlorobenzene

- Methyl ethyl ketone

- Pyntine

- 2,4,5-Trichlorophenol
- Chlordane

- o-Cresol

- 1.4 Dichlorobenzene

- 2,4 Dinturóluene

- Hexachlorobutadiene

- Nitrobenzene

- Tetrachloroethylene

- 2,4,6-Trichlorophenol

The "P" and "U" lists are extremely limited in scope. These lists cover only those products generically identified using the name of a single listed constituent and include only unused portions of these products. Other materials that contain "P" or " $\mathrm{U}$ " listed constituents are not considered hazardous unless they are listed elsewhere in the regulations or exhibit a hazardous characteristic.

Mixture Rule (40 CFR $\$ 261.3(a)(2)$ ). Waste mixtures containing a listed hazardous waste and a nonhazardous solid waste are also defined as hazardous wastes unless the mixture is specifically delisted under 40 CFR \$\$260.20 and 260.22. If the mixture contains a hazardous waste that is listed in 40 CFR Part 261 Subpart $D$ solely because it exhibits one or more of the characteristics listed in Subpart $C$ and the resultant mixture no longer exhibits the characteristic(s) for which it was originally listed, the mixture is not a hazardous waste. (By definition, a mixture of a characteristic waste and a non-hazardous solid waste is hazardous if it exhibits a characteristic).

Derived From Rule (40 CFR \$261.3(c)). Any solid waste derived from the treatment, storage, or disposal of a listed hazardous waste is a hazardous waste (e.g., spill residue, incinerator ash, emission control dust, and leachate), unless it has been delisted under 40 CFR \$\$260.20 and 260.22. (By definition, a solid waste derived from the treatment of a characteristic waste is hazardous if it exhibits a characteristic).

Contained-in Policy. Under the "contained-in" policy, environmental media containing a listed waste (e.g., contaminated soils and ground water) must be managed as if they were hazardous wastes, so long as they 
continue to contain the listed hazardous waste. However, the "derived from" rule does not apply to contaminated environmental media. As a result, such media do not have to be delisted if they are treated so that they no longer contain the listed waste above health-based contaminant concentrations (see Appendix A, EPA Memorandum, "RCRA Regulatory Status of Contaminated Ground Water," 11/13/86, and EPA Memorandum, "Status of Contaminated Ground Water and Limitations on Disposal and Reuse," 1/24/89).

\subsubsection{Wastes Excluded From Subtitle C Regullation}

A number of common waste streams are excluded from regulation under $R$ CRA's hazardous waste program, including household wastes, municipal resource recovery wastes, agricultural wastes, and mining overburden returned to the mine site. Oil and gas wastes, mining wastes, and cement kiln dust are also currently exempted from Subtitle $C$ regulation. Used oil that is generated by small quantity generators, or used oil that exhibits a hazardous characteristic, but is recycled in some way other than being burned for energy recovery, is also exempt. Used oil burned for energy recovery is exempt from Subtitle $\mathbb{C}$, but is regulated under 40 CFR 266.

\subsubsection{Huzardous Constituents Regullated Under RCRA}

In addition to hazardous wastes, RCRA identifies a large number of "hazardous constituents." These constituents potentially pose a threat to human health and the environment and form the basis for listing a solid waste as "hazardous." These constituents play an important role in the RCRA closure regulations, although by themselves, their presence in a waste stream does not automatically define that wastestream as hazardous under RCRA. Other constituent lists play an important role in the RCRA ground-water monitoring program. The four constituent lists, described below, are presented in Exhibit $2-8$.

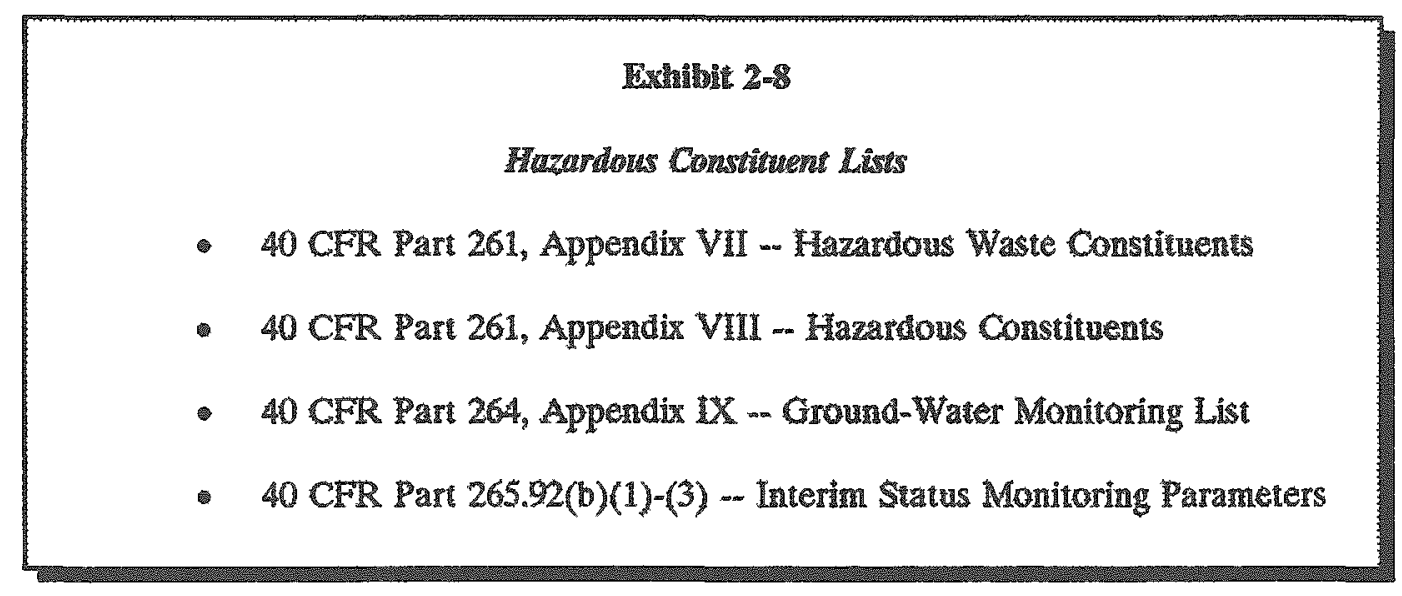

Heazardous Wraste Constituents. Hazardous waste constituents are defined in 40 CFR $\$ 260.10$ as any constituent listed in Part 261 Appendix VII or in Table I of 40 CFR \$261.24. EPA used the Appendix VII constituents as a basis for the listing of specified "F" and " $\mathrm{K}$ " wastes. Table I of $\$ 261.24$ represents those constituents that define a waste as hazardous by the toxicity characteristic. Hazardous waste constituents are used as ground-water assessment monitoring parameters under the interim status monitoring program (Part 265 Subpart F). These parameters are relevant at DOE facilities that are not yet subject to the permitted facility standards of Part 264. In some cases, however, DOE facilities may have previously conducted a clean closure 
using Appendix VII constituents; in such cases, it will be necessary to submit an equivalency demonstration using Appendix VIII constituents (this is described in Section 4.2).

Houzardous Constituents. Part 261 Appendix VII lists a set of over 350 constituents identified as hazardous under RCRA. This list represents chemicals that have toxic, carcinogenic, mutagenic, or teratogenic effects on humans or other life forms. During clean closures, facilities must demonstrate that no Appendix VIII constituents remain above health-based levels in affected environmental media (this is discussed more fully in Section 4.2).

Ground-Water Monitoring List. EPA created a shortened and modified version of Appendix VII for use in the Part 264 Subpart F ground-water monitoring program. This list, Appendix IX of Part 264, contains over 200 constituents that must be monitored for in ground water pursuant to Part 264, Subpart F. These will be relevant during most DOE closure activities where wastes are left in place and at facilities operating with 2 RCRA permit.

Interim Status Monitoring Parameters. $40 \mathrm{CFR} \$ \$ 265.92(\mathrm{~b})$ contain 31 parameters that must be monitored for to establish background ground-water quality at interim status facilities. These constituents are used to determine the suitability of ground water as source of drinking water, the general quality of ground water, and the presence of ground-water contamination. During the detection monitoring phase at an interim status facility, the owner or operator must only monitor for the 10 constituents contained in $40 \mathrm{CFR}$ $\$ 265.92(b)(2)$ and $(b)(3)$ (see Section 2.1.3.2 for a discussion of ground-water protection).

\subsubsection{Delisting Petitions}

Over 90 industrial waste streams are listed as hazardous in 40 CFR Section 261, Subpart D. Because a listed waste from a particular facility may not pose a threat to human health and the environment, $40 \mathrm{CFR}$ $\$ \$ 260.20$ and 260.22 include procedures for petitioning EPA to exclude that waste from regulation. These delisting petitions are subject to public notice and comment. These procedures also may be used for delisting the hazardous component of a mixed waste. If the owner or operator of a facility is able to delist the hazardous component of a mixed waste, the waste is no longer subject to the requirements under RCRA. The delisted material becomes a radioactive waste regulated solely by $\mathrm{DOE}$.

If a facility owner or operator is able to delist the contents of a hazardous waste management unit that will be closed, the wastes which are removed during closure do not have to be disposed as hazardous wastes and are not subject to the Land Disposal Restrictions program (discussed in Section 2.1.4).

EPA has published a guidance document instructing petitioners on how to prepare a complete delisting petition. This document is entitled: "Petitions to Delist Hazardous Wastes - A Guidance Manual," U.S. EPA, Office of Solid Waste, (EPA/530-SW-85-003), April 1985 and is available from the National Technical Information Service (NTIS). 


\subsubsection{Definition of Radionctive Mixed Wastes}

DOE has defined radioactive mixed wastes as follows:

Radioactive mixed waste is waste containing both radioactive and hazardous components regulated by the AEA and RCRA, respectively. The term "radioactive component" refers only to the actual radionuclides dispersed or suspended in the waste substance. (DOE 5400.3: Hazardous and Radioactive Mixed Waste Program (2/22/89))

Any waste containing both a radioactive component regulated by the AEA and a hazardous component regulated by RCRA is radioactive mixed waste; the hazardous component is subject to RCRA regardless of further subclassification as high-level, low-level, or transuranic waste. Mixed waste is not limited to low-level radioactive waste (LLW). Some examples of mixed waste include LLW containing organic lab liquids, cleaning solvents, and heavy metals. If the waste is located in a State which has base RCRA authorization but is not authorized for mixed waste, the hazardous component of the mixed waste is not subject to RCRA, but only to non-RCRA State regulations, if any exist. The radioactive component is always subject to AEA regulations.

RCRA specifically excludes from regulation source, special nuclear, and byproduct material as defined by the AEA On July 3,1986, EPA clarified RCRA's authority to regulate only the hazardous component of mixed waste (51 FR 24504). DOE clarified in a May 1, 1987, Federal Register notice (52 FR 15937), that DOE radioactive byproduct material which is hazardous under RCRA is subject to regulation under both RCRA and the AEA. This rule (the DOE byproduct rule, $10 \mathrm{CFR} 962$ ) applies only to "part (1)" of the definition of byproduct materials, not the tailings and ore residuals defined in "part (2)." Under the final rule, DOE specified that ".. the exclusion appears directed only to the radioactive component of a nuclear waste..." RCRA does not apply to the radioactive component of such a waste; instead the AEA applies to that radioactive component. Finaly, if the application of both regulatory regimes proves conflicting in specific instances, RCRA yields to the AEA." (52 FR 15940).

\subsubsection{Facility Design and Operaring Sturulards (40 CFR Pars 264 and 265)}

The administrative and non-technical requirements for interim status and permitted treatment, storage, and disposal facilities are found in Subparts A through E of 40 CFR Parts 264 and 265. Subparts F and G contain technical requirements for ground-water protection, corrective action, and closure and post-closure care. $^{5}$ Unit-specific requirements are included in Subparts I through $O$ and $X$ of 40 CFR Part 264 and Subparts I through $Q$ of Part 265. The remaining portion of Section 2.1.3 gives a brief overview of the administrative and non-technical standards of Subparts $\mathrm{A}$ through $\mathrm{E}$ and $\mathrm{H}$, and then provides somewhat greater detail on subparts $F$ and $G$. The unit-specific requirements are addressed in Chapter 4 . Exhibit 2-9 lists where these standards are located in the regulations and references the discussions in this guidance manual.

540 CFR Parts 264 and 265, Subpart H inciude financial assurance requirements which do not apply to Federal facilities. 
Exha:bitit 2.9

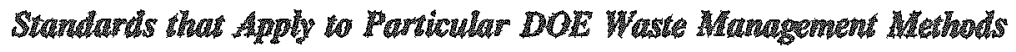

\begin{tabular}{|c|c|c|c|}
\hline \multirow[b]{2}{*}{ Standards } & \multicolumn{2}{|c|}{ Regulatory Cilation } & \multirow[b]{2}{*}{$\begin{array}{l}\text { Discussed } \\
\text { in Section }\end{array}$} \\
\hline & $\begin{array}{l}\text { Permitted } \\
\text { (Pan 264) }\end{array}$ & $\begin{array}{l}\text { merim Status } \\
(\text { Part } 265)\end{array}$ & \\
\hline 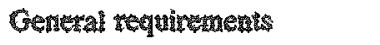 & 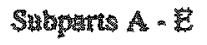 & Suloparta $-\mathrm{E}$ & 21 \\
\hline $\begin{array}{l}\text { Grouad-water monitoringer } \\
\text { and corrective action }\end{array}$ & Subpart $\mathrm{F}$ & Suthare & 21 \\
\hline Closute and posi-closure care & Subpart $\mathrm{G}$ & Subpart $\mathrm{O}$ & 3 \\
\hline Financial assuratace & subpart $H$ & Sulupar H & 211 \\
\hline Containers & Stbpart 1 & Sulbpart & 45 \\
\hline Tatiks & Subpara J & Subopart J & 4.6 \\
\hline Surfece impoundwents & Subpart $\mathrm{K}$ & Swbpan $K$ & 42 \\
\hline Waste piles & \$ubpant L & Subpart L & 43 \\
\hline Land treatment & Sulapart M & Subpart M & 4.4 \\
\hline 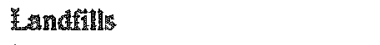 & Subpart $\mathrm{N}$ & Subpan $N$ & 4.1 \\
\hline Incifferators & Subpart & Simpart 0 & 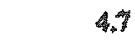 \\
\hline Thermal tressment & NA & Sabpart & 4.8 \\
\hline \multicolumn{4}{|l|}{ Chemicat, physicat, and } \\
\hline biological ireatment & NA & Subpar Q & 48 \\
\hline Miscellaneous unitis & Subpart $X$ & NA & 4.8 \\
\hline $\begin{array}{l}\text { Undergtound injection } \\
\text { wells }\end{array}$ & Part 144 & Part 144 & 4.9 \\
\hline
\end{tabular}

\subsubsection{Administrative and Non-Technical Standards}

The administrative and non-technical standards for interim status and permitted facilities are virtually identical and are located in Subparts $A$ through $E$ of 40 CFR Parts 265 and 264 respectively. Subpart A outlines who is subject to treatment, storage, and disposal regulations. Subpart B contains general facility standards in the following areas: conducting waste analysis; installing security systems; conducting inspections; managing ignitable, reactive, and incompatible wastes; training facility personnel; and location standards. Subparts $C$ and D discuss emergency preparedness and contingency planning. Lastly, Subpart E covers proper manifesting, recordkeeping, and reporting requirements.

\subsubsection{Ground-Water Protection and Corrective Action}

Ground-water monitoring is required only for owners and operators of land disposal units used to manage hazardous waste. In addition, tank systems that eventually close as landfills are subject to groundwater monitoring requirements. Interim status ground-water monitoring standards are located in $40 \mathrm{CFR} 265$, Subpart $F$, while permitted ground-water monitoring standards are found in 40 CFR 264 Subpart F. Interim 
status landfills, surface impoundments, waste piles and land treatment units, upon receiving either an operating permit or a post-closure permit, become subject to the Part 264 ground-water monitoring requirements.

The ground-water monitoring and corrective action requirements for interim status facilities are located in Part 265 Subpart $F$ and are generally less stringent than for permitted facilities. Interim status facilities were required to implement a ground-water monitoring program by November 19, 1980. At interim status facilities, the owner or operator must monitor for parameters establishing ground-water quality and contamination (40 CFR $\$ \$ 265.92(b)(2)$ and (b)(3)) as well as parameters characterizing the suitability of the ground water as a source of drinking water ( $40 \mathrm{CFR} 265$ Appendix III). Presently there are no corrective action requirements for interim status facilities in the regulations; however, RCRA \$3008(h) states that the Regional Administrator can authorize a corrective action order against an interim status facility if he deems that such action is necessary to protect human health or the environment. The $\$ 3008(\mathrm{~h})$ interim status corrective action enforcement authority can be used to order cleanups of releases from all solid waste management units (SWMUs) to all media including off-site releases.

The ground-water protection program for interim status facilities is divided into five phases as follows:

- Development and Installation of Monitoring System (40 CFR \$265.91). The monitoring system must consist of at least four wells, one upgradient from the unit and three downgradient. The upgradient well(s) provide(s) background data for comparing the data from the downgradient wells. Through this comparison, any contamination of ground water can be detected.

- Establishing Buclgrownd Ground-Wuter Quality (40 CFR \$265.92). Monitoring at the upgradient well(s) must take place for one full year to establish background data. Background data are collected for three parameters: 1) drinking water parameters (located in $40 \mathrm{CFR} \$ 265.92$ Appendix III), 2) ground-water quality parameters (located in $\$ 265.92(\mathrm{~b})(2))$, and 3) ground-water contamination parameters (located in \$265.92(b)(3)).

- Detection Monitoring (40 CFR \$265.92). Routine monitoring examines ground water for elevated levels of indicator constituents that suggest that contamination may be occurring. Statistically significant changes in indicator parameters must be reported to the Regional Administrator within seven days of detection. The owner or operator must only monitor for groundwater quality parameters (located in $\$ 265.92(\mathrm{~b})(2)$ ), and ground-water contamination parameters (located in $\$ 265.92(b)(3))$.

- Assessment Progrom (40 CFR \$265.93). If contamination is suspected, the owner or operator must institute an assessment prosiam to determine the nature, extent, and rate of the ground-water contamination. If it is determined that no contamination has occurred, the owner or operator continues routine monitoring. If contamination has occurred, assessment must continue on a quarterly basis until the facility is closed or additional monitoring is required due to the permitting process. If the initial 
assessment occurred during the post-closure period, no further action is required until the facility is issued a post-closure permit.

- Reporting Requinements (40 CFR \$265.94). During the first year of establishing background concentrations, quarterly reports must be submitted. Following that, only annual reports are required from both up- and downgradient monitoring wells.

Interim status facilities that have submitted Part B permit applications are subject to the ground-water information regulations of $40 \mathrm{CFR} \$ 270.14$. Regardless of the status of the facility, a ground-water monitoring program must include the following additional information:

- A summary of the ground-water monitoring data obtained during the interim status period under $\$ \$ 265.90$ through 265.94 where applicable;

- Identification of the uppermost aquifer and aquifers hydraulically interconnected beneath the facility property, including ground-water flow direction and rate;

- A topographic map including the waste management area, the property boundary, the proposed point of compliance, and the proposed location of ground-water monitoring wells;

- A description of any plume of contamination; and

- Detailed plans and an engineering report describing the proposed groundwater monitoring program.

If hazardous constituents have not been detected, the owner or operator must submit sufficient information to establish a detection monitoring program which meets the requirements of $40 \mathrm{CF} R \$ 264.98$. If hazardous constituents have been detected at the point of compliance, the owner or operator must submit sufficient information to establish a compliance monitoring program that meets the requirements of $40 \mathrm{CFR}$ \$264.99. If hazardous constituents have been measured in the ground water which exceed the concentration limits established under $40 \mathrm{CFR} \$ 264.94$, or if ground-water monitoring conducted at the waste boundary during the permit application period indicates the presence of hazardous constituents in excess of background concentrations, the owner or operator must submit sufficient information to establish a corrective action program which meets the requirements of $40 \mathrm{CFR} \$ 264.100$. Information regarding the establishment of a corrective action program does not need to be submitted if the owner or operator can demonstrate to the Regional Administrator that alternate concentration limits will protect human health and the environment after considering the criteria listed in $40 \mathrm{CFR} \$ 264.94(\mathrm{~b})$.

Part 264 Subpart $F$ contains EPA's ground-water monitoring and corrective action program for permitted facilities. All units subject to Subpart F (landfills, suriace impoundments, waste piles, land treatment units, and under certain conditions, tanks) must continue monitoring throughout the closure and post-closure periods, if applicable. The program for permitted facilities is divided into three phases as follows: 
Detection Monitoring (40 CFR \$264.98). The ground water at the downgradient edge of the unit must be monitored for indicator parameters or constituents specified in the permit. If the unit has upgradient ground water that has been contaminated by a non-adjacent source or unit, the contaminants present are considered background levels for the purposes of detection monitoring. If two units are adjacent, the background levels are determined at a point upgradient from both units (i.e., the units are treated as a single unit for the purposes of detection monitoring). Background levels must be established for each of the indicator parameters and constituents. These levels are established by sampling, on a quarterly basis at the upgradient well(s), for one full year. These samples are then compared with downgradient samples taken during the active life of the facility and the post-closure care period, if applicable, to determine if ground-water contamination has occurred. Monitoring must continue during the lifetime of the unit as well as during the post-closure care period, unless compliance monitoring is triggered.

- Complivence Monitoring (40 CFR \$264.99). This phase of the program is triggered when a release is detected at the waste management unit boundary under the detection monitoring program. The owner or operator is required to perform additional investigations to characterize the nature and extent of contamination during compliance monitoring. The constituent levels detected during compliance monitoring are compared against a ground-water protection standard (GWPS) which has been established for each constituent listed in Appendix IX of Part 264 that is included in the permit. The GWPSs are set at either background levels, maximum contaminant levels (MCLs), ${ }^{6}$ or alternate concentration limits (ACLs). ${ }^{7}$ The owner or operator must also submit a ground-water monitoring plan (i.e., corrective action plan) that demonstrates the effectiveness of the corrective action program described below.

- Corrective Action (40 CFR \$264.100). Any owner or operator required to establish a corrective action program must ensure that regulated units are in compliance with the ground-water protection standard under $\$ 264.92$. The Regional Administrator will specify the ground-water protection standard in the facility permit, which will include the following: a list of hazardous constituents identified under \$264.93; concentration limits under $\$ 264.94$ for each of those hazardous constituents; the compliance point under \$264.95; and the compliance period under \$264.96. The corrective action program must prevent hazardous constituents from exceeding their

6 MCLs represent the maximum permissible concentration of 14 specific constituents in drinking water supplies as promulgated by EPA under the Safe Drinking Water Act. The constituents and their MCLs are listed in $\$ 264.94$.

7 ACLs are determined by EPA based on site-specific circumstances. 
respective concentration limits at the compliance point by removing the hazardous waste constituents or by treating them in place so that they do not exceed the concentration limits. The owner operator must establish and implement a ground-water monitoring program to demonstrate the effectiveness of the corrective action program which must be as effective as the program specified under $\$ 264.99$ in determining the ground-water protection standard under \$264.92. The owner or operator must conduct the corrective action program to remove or treat in place hazardous constituents that exceed concentration limits beyond the facility boundary to protect human health and the environment unless the owner or operator demonstrates to the satisfaction of the Regional Administrator that he was unable to obtain the necessary permission to undertake such action. The owner or operator must continue the corrective action measures during the compliance period to ensure that the ground-water protection standard is not exceeded.

Corrective Action for Solid Waste Management Unils (40 CFR \$264.101).

HSWA added two new authorities, Sections 3004(u) and 3004(v), that greatiy expanded EPA's authority to address releases of hazardous waste from solid waste management units (SWMUs) at facilities subject to the RCRA permitting requirements. Section 3004 (u) requires the owner or operator of a facility seeking a permit to institute corrective action for releases from SWMUs to all environmental media, through a permit schedule of compliance (SOC) if necessary. Section 3004(v) extends this far-reaching corrective action provision to include requirements for addressing releases that have migrated beyond the facility boundary. EPA codified the statutory regulations in $40 \mathrm{CFR} \$ 264.101$.

EPA has defined SWMU to include any discernible unit that managed hazardous or solid waste, regardless of whether the unit was intended for managing such wastes (this definition includes "regulated units" subject to the ground-water protection requirements of 40 CFR \$\$264.90 - 264.100). 40 CFR \$264.101 requires investigation and, if necessary, cleanup of releases to all environmental media from all SWMUs, except for releases to ground water from "regulated units," which are covered by $\$ 264.100$.

Since codifying HSWA sections 3004(u) and 3004(v), EPA has been implementing the corrective action program largely through guidance. In addition, it has issued guidelines on the use of the interim status corrective action order authority (HSWA section $3008(\mathrm{~h})$ ), which authorizes EPA to issue orders for corrective action at interim status facilities with releases from solid waste management units. At present, corrective action is typically implemented through the following stages:

- RCRA Fucility Assessment (RFA): EPA Regions will conduct a RFA prior to permitting in order to identify releases from SWMUs to be investigated through the permit SOC. RFAs may be conducted by DOE personnel or contractors at DOE facilities.

- RCRA Fucility Invertigration (RFI): Based on conditions in the final permit SOC, the owner or operator will conduct a RFI to determine the rate, extent, and direction of movement of all contaminants released from SWMUS at the facility. 
- Corrective Measures Study (CMS): When hazardous constituents are identified at levels posing a threat to human health and the environment, the owner or operator will conduct a CMS to evaluate various alternatives for remediating the site.

- Remedy Selection: Upon completion of the CMS, EPA selects a remedy to be instituted by the owner or operator, which must be specified in the permit through a permit modification (which requires public comment).

- Corrective Measures Implementation (CMI): After remedy selection, the owner or operator will implement the remedy and conduct the remedial actions specified in the modified permit.

EPA intends to propose regulations providing detailed procedures and standards for conducting corrective action for releases from solid waste management units (SWMUs) at permitted RCRA facilities. The new corrective action regulations are expected to be proposed as 40 CFR Part 264, Subpart S. These regulations are expected to provide new regulatory definitions, define contaminant levels triggering cleanup, define cleanup standards, and set standards for source control and the management of wastes generated during the cleanup. Pending issuance of these regulations, EPA will continue to implement the corrective action program through 40 CFR \$264.101 and accompanying guidance. In addition, Appendix B contains recent guidance on DOE procedures for complying with these RCRA corrective action requirements. Exhibit $2-10$ summarizes the RCRA corrective action provisions.

\begin{tabular}{|c|c|c|c|c|}
\hline \multirow[b]{2}{*}{$\begin{array}{l}\text { Suatutory } \\
\text { Anethority }\end{array}$} & \multicolumn{3}{|c|}{$\begin{array}{l}\text { Hexhibin } 2-10 \\
\text { RCRA Corrective Action Proviszons }\end{array}$} & \multirow[b]{2}{*}{$\begin{array}{l}\text { Envirommenta } \\
\text { Media Addressed }\end{array}$} \\
\hline & $\begin{array}{l}\text { Reguetatory } \\
\text { Authority }\end{array}$ & $\begin{array}{l}\text { Permitting } \\
\text { Status }\end{array}$ & $\begin{array}{l}\text { Type of } \\
\text { Units }\end{array}$ & \\
\hline $3008(\mathrm{~h})$ & $\mathbf{N A}$ & Interim Status & All SWMUS & All media \\
\hline Pre-HSWA & $\$ 265.90-265.94$ & Interim Status & Regulated units & Ground water \\
\hline Pre-HISWA & $\$ 264.100$ & Permitted & Regulated Units & Ground water \\
\hline$\$ 3004(1)$ & 264.101 & Permitted & All SWMU: & $\begin{array}{l}\text { All media (except } \\
\text { releases from regulated } \\
\text { units } 20 \text { ground water) }\end{array}$ \\
\hline $53004(v)$ & 2264.101 & Permitted & All SWMUs & $\begin{array}{l}\text { All media for } \\
\text { off-site releases }\end{array}$ \\
\hline
\end{tabular}




\subsubsection{Closure and PosinClosure Care}

The closure and post-closure care requirements for hazardous waste treatment, storage, and disposal facilities (TSDFs) are found in Subpart G of Parts 264 and 265 and in specific sections of Subparts I through $O$ and $X$ as applicable to process-specific requirements. The regulations apply only to those units at a facility that treated, stored, or disposed of wastes after November $19,1980$.

All facilities that treat, store, or dispose of hazardous wastes on-site for longer than 90 days must comply with all applicable closure requirements. In addition, owners or operators of hazardous waste disposal units $^{8}$ must conduct monitoring and maintenance activities for 30 years after closure to ensure that pollutants are not released to the environment. The Regional Administrator has the authority to extend or reduce the period for post-closure care on a case-by-case basis. Generators accumulating waste on-site for 90 days or less are subject to EPA's general closure performance standard and facility decontamination requirements ( $40 \mathrm{CFR}$ \$265.114), specifying that all contaminated equipment, structures, and soils must be properly disposed of or decontaminated.

The general Subpart $G$ closure and post-closure care requirements for permitted and interim status facilities are specified in 40 CFR \$\$264.110 through 264.120 and 40 CFR \$\$265.110 through 265.120. These requirements apply uniformly to all types of hazardous waste management units and are discussed in Chapter 3. The process-specific Subparts provide further detail and additional standards, as necessary, for the proper closure and post-closure care of hazardous waste management facilities. The requirements are explained separately in Chapter 4 for each RCRA hazardous waste management unit and underground injection wells.

\subsubsection{Fincuncial Assurcance Requirements}

$40 \mathrm{CFR} \$ \$ 264.140(\mathrm{c})$ and $265.140(\mathrm{c})$ stipulate that States and the Federal government are exempt from the financial assurance requirements contained in Subpart $\mathrm{H}$. Therefore, operators of DOE facilities are not subject to RCRA financial assurance requirements.

\subsubsection{Lacation Standlards}

HSWA required EPA to promulgate standards for location of hazardous waste management facilities, which are to be proposed as Part 264 Subpart $\mathbb{Z}$. The promulgation date of these standards is uncertain. These new standards may have a dramatic impact on facility operations by forcing some owners or operators to close or remove all waste from their facilities based on the sensitivity of their location. For more information on the potential impact of proposed location standards on DOE facilities see Appendix F, DOE Memorandum, EH-231, "Environmental Protection Agency Proposal to Broaden Restrictions for the Siting of RCRA Hazardous Waste Facilities," 3/13/89.

8 Disposal units are those units at which wastes are left in place after closure including landfills, land treatment units, and surface impoundments, waste piles, and tank systems that cannot be "clean closed" and must be closed as landfills. 


\subsubsection{Land Disposal Restrictions (40 CFR Part 268)}

The land disposal restrictions (LDRs) program restricts the land disposal of RCRA hazardous wastes beyond certain statutory dates established by Congress in HSWA. Restricted hazardous wastes include all solvent- and dioxin-containing wastes, "California list" wastes (i.e., certain metals, corrosives, cyanides and halogenated organic compounds as defined in HSWA), as well as "First Third, "Second Third," and "Third Third" scheduled wastes.

With HSWA, Congress established a rigid schedule for the implementation of the land disposal restrictions. To enforce this rigid schedule, Congress also prescribed "hammer" dates -- deadlines beyond which land disposal would be automatically prohibited. Congress directed that treament standards be set for solvent- and dioxin-containing wastes by November 8, 1986, and "California list" wastes by July 8, 1987. Congress also đirected that EPA rank all remaining listed and characteristic wastes by volume and intrinsic hazard and divide the list into thirds, promulgating treatment standards according to the following schedule: "First Third" scheduled waste by August 8, 1988; "Second Third" scheduled waste by June 8, 1989; and all remaining waste by May 8,1990 . Congress' final direction was that any waste for which treatment standards were not set by May 8,1990 , is automatically prohibited from land disposal; this is referred to as the "hard hammer."

EPA met the Congressionally imposed schedule. The LDRs are codified in 40 CFR Part 268 and have been incorporated into the RCRA program through a series of final rules:

- The "Schedule" rule (May 28, 1986; 51 FR 19300);

- The "Solvent and Dioxin" rule (November 7, 1986; 51 FR 40572, and corrections on June 4, 1987; 52 FR 21010);

- The "California List" rule (July 8, 1987, 52 FR 25760); and

- The "First Third" rule (August 17, 1988; 53 FR 31138) the "Second Third" rule (June 23, 1989; 54 FR 26594) and the "Third Third" rule (May 8, 1990; 55 FR 22520).

- Treatment standards promulgated for solvent- and dioxin-containing wastes and California list wastes apply to mixed waste that falls into these categories. Treatment standards for all other categories of mixed waste are contained in the "Third Third" rule.

LDRs require that if a waste is to be placed in or on the land (e.g., in a surface impoundment, landfill, waste pile), the waste must comply with the specified treatment standards. For example, where treatment standards are expressed as concentration levels for a waste, the waste cannot be placed in or on the land unless the concentration of regulated constituents is below the promulgated standards, usually after treatment. Thus, LDRs are "triggered" when waste is placed in or on the land. If placement does not occur (e.g., in-situ treatment, capping in place), the LDRs do not apply to the waste management activity. Diagrams on the definition of placement have been included as Appendix $C$. 
HSWA states that the LDR treatment standards are to be protective of human health and the environment and must substantially diminish the toxicity of a waste or substantially reduce the likelihood that hazardous constituents would migrate from the waste. EPA has set and continues to set treatment standards based on the Best Demonstrated Available Technology (BDAT) approach where "best" identifies the treatment technology that offers the greatest reduction of toxicity, volume, or mobility of the waste. "Demonstrated" signifies that the technology is performed at full-scale operation, and "available" ensures that the technology is commercially viable (i.e., available for purchase or lease). Using the BDAT approach, EPA has set treatment standards for wastes as (1) concentration levels which must be attained prior to land disposal, (2) specified treatment technologies which must be employed, and (3) "no land disposal" in cases where a waste either can be totally recycled without generating a prohibited residue, or is not currently being land disposed, or is no longer being generated and the waste is not anticipated to be generated during a RCRA Or CERCLA corrective action.

EPA has not made a distinction in setting treatment standards between RCRA hazardous waste and mixed waste. Thus, the treatment standards promulgated for a particular waste code, such as F011, apply to mixed F011 waste as well. Currently, the treatment standards promulgated for solvent- and dioxin-containing waste and California list waste apply to mixed waste that falls into these categories.

The case for all other wastes, however, is different. In the August 17, 1988, "First Third" final rule, EPA postponed treatment standards for mixed waste and leachate (and thus mixed leachate waste) derived from RCRA hazardous waste until the "Third Third" rule, which was promulgated on May 8, 1990. In the "Third Third" rule, EPA granted a 90-day lack of national treatment capacity extension (until August 8, 1990) of the effective date for all provisions in the "Third Third" rule. Certain wastes restricted in the rule were granted an additional national capacity variance from the LDRs for up to two years. National capacity variances were not granted a delay in the effective date, and will therefore extend from May 8, 1990 to May 8, 1992. The wastes receiving a national capacity variance are listed in Exhibit 2-11.

LDRs must be addressed in a facility's closure plan. If complete closure, or partial removal of wastes is planned, the plan must specify whether the wastes are subject to the LDRs, and if so, how they will be managed in accordance with the restrictions. Closure plans prepared prior to the promulgation of LDRs may need to be amended. For landfill closures, the owner or operator must investigate whether closure activities constitute land disposal (also referred to as "placement"). Movement of a waste within a unit, in-situ waste treatment, and capping wastes in place does not constitute land disposal; however, if wastes are removed from the unit, treated (e.g., stabilized), and placed back into the unit, it is considered land disposal and the wastes are subject to the LDRs.

Variances, extensions, and petitions to several components of the hazardous waste land disposal restrictions are allowed. These variances, extensions, and petitions do not exempt the petitioner from the LDRs; instead, they provide alternative methods of compliance with the restrictions. For example, wastes granted a two year capacity variance on the effective date of the "Third Third" rule are "restricted" (e.g., these wastes must be handled at a facility that meets minimum technology requirements) during the period for which the variance is granted. EPA has developed the following supporting guidance on how to prepare variances, extensions, and petitions: No-Migration Variances to the Hazardous Waste Land Disposal Prohibitions (DRAFT: December 1987); Generic Quality Assurance Project Plan for the Land Disposal Restrictions Program (EPA/530SW-87-011); Case-by-Case Extensions: A Guidance Document to Support the Land Disposal Restrictions (Working Draft: 1988), and Treatability Variance Equivalency Demos on LDRs. 
IXxhibid 2-11

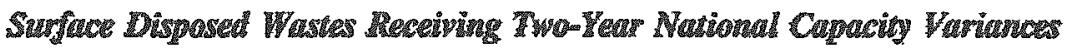

Technology

Waste Code

A

Vìtrifection

Combustion of Sludgetsolids

Acid reaching and chemical Precipitation (low tercury) and mercury retoring (high mercry)

Secondary Smeltug

thermat Recovery

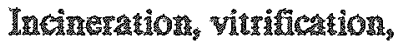
and mercury retoriag
All scheduled mixed hazardous/tadioactive wastes and inorganic debris

D004, K031, K084, K101, K102, PO10, PO11, PO12, POS6, P038, U136

FO39 1, KO48-1KO52 c

D009, K106, P065, P092, U15

0008

P015 and P087

Soil and Debris

- Vartances are granted only to the nonwastewater forms.

b/ Mutiti-source leachare.

ef Capacity extension only unat Noventber \&, 1990.

d Doos lead+acid batteries.

\subsection{ATOMIC ENERGY ACT}

The Atomic Energy Act (AEA), logether with the Energy Reorganization Act (ERA), authorizes DOE to regulate radioactive material operations at many government-owned facilities and several inactive sites that contain radioactive contamination. DOE carries out its regulatory responsibilities for radioactive mixed wastes through selected DOE Orders (discussed below).

\subsection{DOE ORDERS}

DOE Orders contain many requirements applicable to the management of radioactive mixed wastes. These requirements are in addition to those stipulated under RCRA. An overview of Orders relevant to the 
closure of units containing radioactive mixed wastes at DOE facilities is provided in the following sections as background information for the hazardous component of radioactive mixed waste.

\subsubsection{DOE 5400.1: General Environmentul Protection Program (11/9/88)}

DOE Order 5400.1 authorizes DOE facilities and personnel to comply with the requirements under RCRA and other Federal environmental statutes. Mixed wastes are not specifically addressed (clarified in DOE 5400.3 -- described below); however, the Order makes reference to specific environmental protection standards which are required for DOE operations unless an exemption can be obtained. These standards include:

- 40 CFR 190, "Environmental Protection Standards for Nuclear Power Operations;"

- 40 CFR 191, "Environmental Radiation Protection Standards for Management and Disposal of Spent Nuclear Fuel, High-Level, and Transuranic Wastes;"

- 40 CFR 192, "Health and Environmental Protection Standards for Uranium and Thorium Mill Tailings;" and

- 40 CFR 193 (when final) "EPA Draft on LLW Standards."

Other information in DOE Order 5400.1 includes procedural requirements for long range environmental protection planning, notification and reporting, and environmental monitoring.

\subsubsection{DOE 5400.3: Hazardous and Radionctive Mixed Waste Program (2/22/89)}

This Order clarifies DOE 5400.1 as it applies to mixed wastes. It specifies that all DOE hazardous and mixed wastes will be managed according to Subtitle C of RCRA and specifies that RCRA applies to the extent it is not inconsistent with the AEA. The Order also specifies that the radioactive component of the mixed waste is subject to the requirements of DOE 5820.2A. The Order also direcis the Assistant Secretary for Environment, Safety, and Health (EH-1) to develop and issue policies, guides, requirements, and procedures for implementing the requirements of RCRA at DOE facilities and integrating them with the requirements of CERCLA and NEPA.

\subsubsection{DOE 5400.5: Radication Protection of the Public and the Environment (2/8190)}

This order establishes standards and requirements for the operations of the DOE and DOE contractors with respect to protection of the public and the environment against undue risk from radiation. The order updates the portions of DOE 5480.1A that address public and environmental radiation protection standards and control practices. This order adopts and implements radiation protection dose standards consistent with the recommendations of the International Commission on Radiological Protection (ICRP). The order requires the DOE to comply with legally applicable rules and regulations of other Federal, State and local agencies. 


\subsubsection{DOE 5480.11: Radiation Protection for Occupational Workers (12/21/88)}

DOE 5480.11 establishes the requirements for radiation protection of various population groups. Specifically, the Order addresses exposure to occupational workers, unborn children, students, minors, and onsite members of the public. According to the order, it is DOE's policy to limit exposures to radiation to levels that are As Low As Reasonably Achievable (ALARA). ${ }^{9}$ Guidelines on achieving the objective of the ALARA process are found in PNL-6577, "Health Physics Manual of Good Practices for Reducing Radiation Exposure to Levels that are As Low As Reasonably Achievable (ALARA). "Radiation protection standards to be used for determining radiation doses are specified in the order. Additional information is provided on contamination control, monitoring, and safety training.

\subsubsection{DOE 5820.2A: Reuliouctive Wraste Mandement (9/26/88)}

DOE 5820.2A replaces DOE 5820.2, Radioactive Waste Management of 2/6/84. The purpose of the Order is to establish policies and guidelines for managing the DOE's high-level waste and any other material which, because of their highly radioactive nature (level of health risk, longevity of health risk and thermal activity), require similar handling (DOE Order 5820.2A, p.I-1). The Order is divided into three sections, one for each of the following types of radioactive wastes: high-level waste, ${ }^{10}$ transuranic waste, ${ }^{11}$ and low-level waste. ${ }^{12}$ Specific information is provided related to the generation, treatment, and disposal of these waste types.

\subsubsection{High-Level Rediouctive Warte}

According to DOE 5820.2A, all high-level radioactive wastes are considered to be radioactive mixed wastes and subject to the AEA and RCRA unless demonstrated to the contrary. The following guidance is provided for the management of high level waste.

9 ALARA is defined as "an approach to radiation protection to control or manage exposures (both individual and collective to the work force and general public) as low as social, technical, economic, practical, and public policy considerations permit. As used in this Order [DOE 5480.11], ALARA is not a dose limit but a process, which has the objective of dose levels as far below applicable limits of the Orders as reasonably achievable."

10 High-level waste is "the highly radioactive waste material that results from the reprocessing of spent nuclear fuel, including liquid waste produced directly in reprocessing and any solid waste derived from the liquid, that contains a combination of transuranic waste and fission products in concentrations requiring permanent isolation."

11 Transuranic waste is defined as, "Without regard to source or form, waste that is contaminated with alpha-emitting transuranium radionuclides with half-lives greater than 20 years and concentrations greater than $100 \mathrm{nCi} / \mathrm{g}$ at the time of assay. Heads of field elements can determine that other alpha contaminated wastes, peculiar to a specific site, must be managed as transuranic wastes."

12 Low-level waste is "waste that contains radioactivity and is not classified as high-level waste, transuranic waste, or spent nuclear fuel or ... byproduct material... " 
Waste Characterization. Liquid and solidified high-level waste must be characterized consistent with radiation protection requirements to determine its hazardous components, per $40 \mathrm{CFR} 261$ and $40 \mathrm{CFR} 264$. Characterization shall satisfy requirements of paragraph $3 b(1)(b)$ and may reflect knowledge of waste generating processes, laboratory testing results, and/or the results of periodic sampling and analysis. Examples of required information are chemical composition, physical properties, radionuclide concentrations, and $\mathrm{pH}$ (DOE Order 5820.2A, P I-2).

Storage \& Trunsfer Operutions. The Order requires segregation of waste by type (siudge, salt, high activity, and low activity) to make accessibility for future processing easier. It also specifies that "each facility shall utilize remote maintenance features and other appropriate techniques to minimize personnel radiation exposure in accordance with DOE 5481.1B."

Dispesal. Wastes will be processed and the high-level waste fraction disposed of in a geological repository according to the requirements of the Nuclear Waste Policy Act of 1982. Interim storage for highlevel waste awaiting transport to the repository must comply with the above storage requirements.

\subsubsection{Management of Transuranic Waste}

Guidance on the management of transuranic wastes (mixed and non-mixed) in DOE 5820.2A is summarized below.

Disposal. Mixed transuranic waste meeting the requirements of the Waste Isolation Pilot Plant (WIPP) Waste Acceptance Criteria are to be are to be sent to the WIPP (wastes will be placed in interim storage until the WIPP becomes operational). Information on WIPP waste acceptance criteria certification is provided in DOE 5820.2A, Radioactive Waste Management, September 26, 1988.

Temporary/Interim Storage. Segregation of transuranic waste from low-level and high-level radioactive waste is required. Other requirements such as contingency plans, monitoring, etc, are detailed in the Order.

Waste Characterization. The determination of whether the transuranic waste exhibits any hazardous characteristics or contains listed hazardous wastes may be based upon knowledge of the waste generating process when the performance of a chemical analysis would significantly increase the radiation hazard to personnel. Transuranic wastes shall be assayed or otherwise evaluated to determine the kinds and quantities of transuranic radionuclides present prior to storage.

Treament. The Order specifies that mixed transuranic wastes must be treated, where feasible and practical, to destroy the hazardous waste component. Also specified in the Order are requirements for buried transuranic-contaminated waste. Inactive wastes sites containing buried transuranic-contaminated waste are located at INEL, Los Alamos, Oak Ridge, the Savannah River Plant, and the Hanford Site. The Order specifies three site-closure strategies for these sites:

- Dispose of waste in place with enhanced monitoring;

- Dispose of waste in place, with enhanced confinement or in-situ immobilization techniques, and enhanced monitoring; and

- Retrieval, processing, and isolation of the transuranic waste at the WIPP. 


\subsubsection{Management of Low-Level Waste}

Guidance on the management of low-level wastes (mixed and non-mixed) in DOE 5820.2A is summarized below. (See Appendix $\mathrm{H}_{2}$ NRC-EPA Guidance on Siting of Mixed Low-Level Radioactive and Hazardous Waste Units).

DOE Performance Standards. Low-level waste must be managed to protect public health and safety in accordance with standards specified in applicable DOE Orders and to assure that:

- External exposure to the waste and concentrations of radioactive material which may be released into the surface water, ground water, soil, plants and animals results in an effective dose equivalent that does not exceed $25 \mathrm{mrem} / \mathrm{yr}$ to any member of the public. Releases to the atmosphere shall meet the requirements of $40 \mathrm{CFR} 61$. Reasonable effort should be made to maintain releases of radioactivity in effluents to the general environment as low as is reasonably achievable. and

- The committed effective dose equivalents received by individuals who inadvertently may intrude into the facility after the loss of active institutional control ( 100 years) will not exceed $100 \mathrm{mrem} / \mathrm{yr}$ for continuous exposure or 500 mrem for a single acute exposure.

Wraste Segregution. Each DOE low-level waste generator will separate uncontaminated waste from lowlevel waste to facilitate cost effective treatment and disposal.

Weaste Charcterization. Waste characterization data contained on manifests incluce the physical and chemical characteristics of the waste, volume and weight (total of waste and any solidification or adsorbent media), major radionuclides and their concentrations, and packaging date, package weight, and external volume. "The concentration of a radionuclide may be determined by direct methods or by indirect methods such as use of scaling factors which relate the inferred concentration of one radionuclide to another that is measured, or radionuclide material accountability, if there is reasonable assurance that the indirect methods can be correlated with actual measurements" (DOE Order 5820.2, p.III-3).

Waste Treatment. Treatment must meet DOE performance standards referred to above. Waste treatment techniques such as incineration, shredding, and compaction to reduce volume and provide more stable waste forms shall be implemented as necessary to meet performance requirements. Use of waste treatment techniques to increase the life of the disposal facility and improve long-term facility performance, by improved site stability and reduction of infiltrating water, is required to the extent it is cost effective.

Disposal. Field organizations with disposal sites must prepare and maintain a site-specific "radiological performance assessment" for the disposal of waste for the purpose of demonstrating compliance with the performance standards shown above. The performance assessment model is used to develop stabilization, packaging, etc. programs for low-level wastes. Additional disposal requirements include:

- Liquid wastes, or wastes containing free liquids, must be converted into a form that contains as little freestanding and noncorrosive liquid as is reasonably achievable, but, in no case, shall the liquid exceed 1.0 percent of 
the volume of the waste when the waste is in a disposal container, or 0.5 percent of the volume of the waste processed to a stable form.

- Waste must not contain, or be capable of generating, quantities of toxic gases, vapors, or fumes harmful to persons transporting, handling, or disposing of the waste. This does not apply to waste in a gaseous form which must be packaged at a pressure that does not exceed 1.5 atmospheres at $20^{\circ} \mathrm{C}$.

- Waste containing amounts of radionuclides below regulatory concern, as defined by Federal regulation may be disposed without regard to radioactivity content.

- Disposal sites must be selected in accordance with NEPA process.

Clasure. During closure and the post-closure care period, residual radioactivity leveis for surface soils shall comply with existing DOE decommissioning guidelines. ${ }^{13}$ Corrective measures must be applied if conditions occur or are forecasted that could jeopardize attainment of the performance objectives of this Order.

Environmental Monicoring. Environmental monitoring program must conform with DOE 5484.1B. It must measure, at a minimum: operational effluent releases; migration of radionuclides; disposal unit subsidence; and changes in disposal facility and disposal site parameters which may affect long-term site performance.

\subsection{FEDERAL FACILITY COMPLINCE AGREEMENTS}

Federal agencies must comply with all provisions of Federal environmental statutes and regulations as well as all applicable State and local requirements, with minor exceptions. Federal facilities, including DOE facilities operating under the Atomic Energy Act of 1954, are required by Section 6001 of RCRA to comply with all of the requirements of RCRA to the same extent as any private person or eatity. EPA has interpreted the term "facility" when applied to federally owned properties, to mean the entire site under the control of an individual Federal department or Agency.

When incidents of non-compliance occur at Federal facilities, regulating agencies issue notices of violations. Non-compliance is generally identified during normal inspections, although DOE may identify noncompliance through self-assessment as well. While some violations are minor and can be quickly corrected once identified, some violations may require extensive action or require additional time or funds to be allocated to bring a facility back into compliance. To better address these major compliance issues, DOE generally seeks to negotiate compliance agreements with the relevant regulatory agency(ies) that commit $\mathrm{DOE}$ to specific activities and schedules to achieve compliance. This is because, according to the Department of Justice, a Federal agency cannot issue an "order" to another agency. (RCRA 3008 $(h)$ for corrective action is

13 Decommissioning refers to actions taken to reduce the potential health and safety impacts of DOE contaminated facilities, including activities to stabilize, reduce, or remove radioactive materials or to demolish facilities. 
an exception to this rule; EPA can issue an order by consent to another Federal agency for RCRA cleanup at interim status facilities). Compliance agreements are formal, enforceable administrative actions that, as long as commitments are met, generally make other types of enforcement actions unnecessary.

Compliance agreements between DOE facilities and EPA or State agencies to address RCRA noncompliance are established primarily through Consent Orders and/or Federal Facility Compliance Agreements (FFCAs). Whether a Consent Order or a FFCA is negotiated with a DOE facility depends on two factors: (1) whether the State has authorization to implement RCRA regulations in lieu of EPA and (2) what type of RCRA violation has been cited if EPA is the authority enforcing the RCRA regulations.

For a facility located in a State authorized to implement the RCRA requirements that are identified in a notice of non-compliance, the activities needed to achieve compliance are generally conducted pursuant to a Consent Order with the State. If the facility is located in State without RCRA authorization or without authorization to enforce the particular RCRA requirement identified in the notice of non-compliance (e.g.s HSWA corrective action), then compliance activities are conducted pursuant to either a Consent Order or a FFCA with EPA. Compliance activities that involve RCRA Section 3008(h) interim status corrective action are addressed in a Consent Order with EPA. All other needed compliance activities are conducted under a FFCA with EPA. Therefore, closure violations and other compliance problems involving on-going operations of TSDFs are addressed under FFCAs with EPA. Cleanup of releases from solid waste management units are handled under the permit under 3004(u) and (v) authorities.

Depending on the nature of the violations at a DOE facility, compliance activities may be undertaken under multiple authorities. For example, if a State is authorized to enforce closure regulations but not corrective action, and the violation includes both closure and corrective action components, the State would negotiate a Consent Order to cover the closure violations and EPA would negotiate a Consent Order under 3008(h) authority to cover corrective action activities for the interim status units. This particular situation would preferably be addressed pursuant to a single three-party Consent Order/FFCA. Therefore, at a particular facility, there may be multiple enforcement mechanisms and multiple parties involved in the agreements depending on the type of actions required and the specific legal and regulatory authorities involved.

In general, orders or agreements include, at a minimum, the following information:

- Legal authorities which are the basis for the order or agreement;

- Description of alleged violation (e.g., inadequate closure plan);

- Compliance plan;

- Schedules for compliance; and

- Procedures for dispute resolution

- Sanctions for continued noncompliance.

Exhibit 2-12 illustrates the types of compliance agreements used by EPA or States. 
Cxhibis 2-12

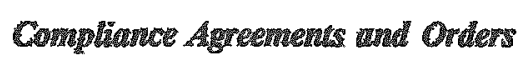

RCRA Proviston

EA Administers

State is Authorized

RCRA sequturements

FWA

Consent Order

for active units

Corrective action

Consent Order

Consent Order

under 3008 (h)

Corrective actor

under $3004(u)$ vall

HSW A Permin

HSWA Permit

$3004(v)$ 


\section{REFERENCES: CHAPTER 2}

DOE 5400.1, "General Environmental Protection Program," November 9, 1988.

DOE 5400.3, "Hazardous and Radioactive Mixed Waste Program," February 22, 1989.

DOE 5400.5, "Radiation Protection of the Public and the Environment," February 8, 1990.

DOE 5480.11, "Radiation Protection for Occupational Workers," December 21, 1988.

DOE 5484.1B, "Safety Analysis and Review System," May 19, 1987.

DOE 5820.2A, "Radioactive Waste Management," September 26, 1988.

DOE's Byproduct Rule, 10 CFR 962.

DOE Memorandum, "Corrective Action Plan, Interim Measures Guidance, National Strategy, and Model Consent Order," 1/2/90.

EPA/530-SW-84-004, "Permit Applicants' Guidance Manual for Hazardous Waste Land Treatment, Storage, and Disposal Facilities, Final Draft," May 1984.

EPA/530-SW-85-003, "Petitions to Delist Hazardous Wastes--A Guidance Manua1," U.S. EPA Office of Solid Waste, April 1985 (available from NTIS).

EPA/530-SW-87-011, "Generic Quality Assurance Project Plan for the Land Disposal Restrictions Program." EPA's "Case-by-Case Extensions: A Guidance Document to Support the Land Disposal Restrictions, "Working Draft, 1988.

EPA's "No-Migration Variances to the Hazardous Waste Land Disposal Prohibitions," Draft, December 1987.

PNL6577, "Health Physics Manual for Good Practices for Reducing Radiation Exposure to Levels that are As Low As Reasonably Achievable (ALARA)." 


\section{PROCEDURAL REQUIREMENTS FOR CLOSING HAZARDOUS AND MIXED WASTE UNITS}

This chapter provides a brief overview of the general requirements for closure and post-closure care of hazardous and mixed waste facilities found in 40. CFR Parts 264 and 265 Subpart G. The Subpart G requirements are applicable to all facilities at which hazardous wastes (including the hazardous waste component of mixed waste) have been treated, stored, or disposed. The unit-specific technical requirements for closure and post-closure care at hazardous and mixed waste units are discussed in Chapter 4.

The ciosure and post-closure care regulations apply only to those hazardous waste management units at the facility that treated, stored, or disposed of hazardous wastes on or after November 19, 1980. A hazardous waste management unit is defined in 40 CFR $\$ 260.10$ as a contiguous area of land on or in which hazardous waste is placed, or the largest area in which there is a significant likelihood of mixing hazardous waste constituents in the same area. Examples of hazardous waste management units include a surface impoundment, a waste pile, a land treatment area, a landfill cell, an incinerator, a tank and its associated piping and underlying containment system, and a container storage area. ${ }^{14}$ If a unit (e.g., a landfill cell) or any part of a unit (e.g., several containers of waste in a single storage shed) was active on the effective date of the regulations, the entire unit is subject to the closure and post-closure care regulations. In addition, if the unit has released hazardous constituents to the environment, the unit may be subject simultaneously to corrective action under $40 \mathrm{CFR} \$ 264.100$ or $\$ 264.101$.

Exhibit 3-1 on the following page summarizes the key provisions of the closure and post-closure care regulations and references to the sections of this chapter that provide more detailed information. A supplemental discussion to this guidance document on the closure and post-closure care requirements for hazardous waste facilities can be found in the Draft RCRA Guidance Manual for Subpart G Closure and PostClosure Care Standards and Subpart H Cost Estimating Requirements, January 1987, U.S. Environmental Protection Agency, OSWER Policy Directive \$9476.00-5.

\subsection{THE SUBPART G CLOSURE REQUIREMENTS}

The closure requirements are found in $\$ \$ 264.111$ - 264.116 for permitted facilities and $\$ \$ 265.111$ 265.116 for interim status facilities. The closure requirements apply to all hazardous waste management facilities and are virtually identical except for procedural matters for both permitted and interim status facilities. In addition, the closure performance standards found in 40 CFR \$\$264.111 and 265.111 incorporate by reference, unit-specific requirements, some of which differ between permitted and interim status facilities. As explained in Chapter 2 of this document, if a facility that handles radioactive mixed waste is located in a State without base RCRA authorization, the waste is subject to Federal RCRA and radioactive waste requirements, as well as State requirements if any exist. For facilities located in States with base RCRA authorization and without radioactive mixed waste authorization, the mixed waste is not even defined as hazardous waste, and thus the hazardous component of the mixed waste is not regulated under RCRA. State regulations, however, may apply. After September 25, 1990, if the mixed waste exhibits the toxicity characteristic, it is defined as hazardous waste regardless of the authorization status of the State (see Section 2.1.2.1). If the facility is located in a State with mixed waste authorization, then only State regulations apply.

14 A container alone does not constitute a unit; the unit includes the containers and the land or pads upon which they are placed. 
Exh:D昉 3-1

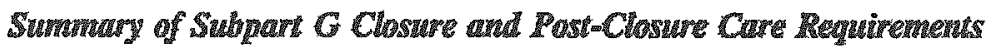

All hazadous and mixed waste TSDFs nust comply with the closure performance standard and with he unitspecific technical requiremekts.

Section 3.1.1

All hazardous and mixed waste TSDFs must prepare closure and, closure plans.

Section 3.1 .2 and 3.2 .2

All closures must be in accordance whith specified deadlines.

Section 3.1 .3

All partal and mal clasures must inchude renoval or decontamination of contaminated facility equipment, structures, and, 站 apropitate, solus.

Section 3.1.6

Completion of closure and post-closure car anust be certified by an indepentent registered protessional engineer.

SActions 3.1 .7 and 3.2 .3

Survey ptats and post-closure notices must be submitted after chosure of each disposal

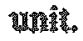

Section 3.1 .8

All disposal units require 30 years of post-closure monitorimg and maintenance. Allernate postoclosure care periods may be approved by the Regional Administrator.

Section 3.2 .1

Owners or operators of permitted storage surface impoundments and waste piles not designed in accordance with specified liner design standards, and all tank systems without secondary contaiment must prepare contingent closure and post-closure plans describing activitzes requatred to close the nnit as a landfill and conduct post-ciosure care.

Section 3.3

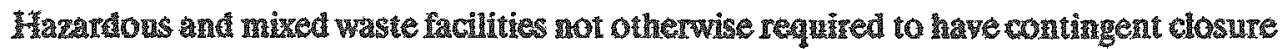
and postmelosure plans nust revise thei closure plans and prepare post+closure plans if ail hazardons wastes cannot be removed at closere and the unit must be closed as a landfill.

Section 3.3 


\subsubsection{The Closure Performanuce Stamdard}

40 CFR \$\$264.111 and 265.111 provide the general performance standard that facilities must satisfy at closure and incorporate by reference the unit-specific technical standards (which are discussed in Chapter 4 of this document). The general closure performance standard requires that hazardous and mixed waste facilities be closed in a manner that:

- Minimizes the need for further maintenance, and

- Controls, minimizes or eliminates, to the extent necessary to protect human health and the environment, posi-closure escape of hazardous waste, hazardous constituents, leachate, contaminated run-off, or hazardous waste decomposition products to the ground or surface waters or to the atmosphere.

- Complies with the closure requirements of Subpart $G$, including, but not limited to, the requirements of $\$ 264.178,264.197,264.228,264.280,264.310$, 264.351, and 264.601-603.

In order to be in compliance with \$\$264.111 and 265.111, facilities must comply with both the general performance standard and the technical closure standards -- one does not override the other. The unit specific technical requirements specify the particular activities that must be included in the closure plan and conducted as part of closure of that type of unit.

\subsubsection{The Closure Plan}

All hazardous and mixed waste facilitjes, in accordance with 40 CFR \$\$264.112 and 265.112 , must have written closure plans describing how each unit at the facility will be closed. The regulations specify the required contents of the closure plan but do not require the owner or operator to adhere to any particular format when developing the plan. $40 \mathrm{CFR} \$ \$ 264.112(\mathrm{~b})$ and $265.112(\mathrm{~b})$ describe the minimum information to be included in the closure plan (see Exhibit 3-2).

The information presented below is a summary of the minimum information required in a closure plan for any type of unit or facility. The precise information that must be included in the plan varies depending on the type of units being closed.

\subsubsection{Facility Description}

The facility description should include the following types of information:

- Facility location;

- General description of hydrogeologic conditions:

- Description of hazardous waste management units at the facility; and

- References to other environmental permits and exemptions. 


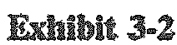

Closure Plan Regurirements

Contents of the Closure Plan

Regulatory Citation

Facility description

\$연.264.112(a)(2) and 265.112(a)(2)

Partial closure acanuties

ร.5.264.12(b)(1) and $265.112(b)(1)$

Estimate of maximum extent ar operations and maximum invertory

$\$ 8264.112(b)(2)$ and $265.112(b)(2)$

Treating, removing, or disposing of the

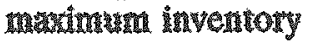

Facilizy decontamination

$85264.112(0)(4)$ and $265.12(0)(4)$

Orownd-water monitoring

$\$ 264.12(b)(5)$ and $265.112(b)(5)$

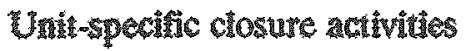

\$3264.12(b)(5) and 265.112(b)(5)

Potrial and final closure schedute

$58264.112(b)(6)$ and $265.112(b)(6)$

\subsubsection{Partial Closure Activities}

Closure of a hazardous waste management unit at a facility that contains other active hazardous waste management units is defined as partial closure. Examples of partial closures include closure of a tank (including its associated piping and underlying containment systems) or a landfill cell (40 CFR $\$ 260.10$ ). Removing a drum or container from a container storage building is not a partial closure; however, closing the entire storage area at a facility that continues to operate other types of waste management units does qualify as a partial closure. Closure plans must describe in detail the proposed procedures for closing all units at the facility, including all partial closures. This description should include all decontamination, removal, treatment, monitoring, capping, and other activities necessary for closure of the unit. 


\subsubsection{Estimate of Maximum Extent of Operation}

The closure plan must include an estimate of the maximum extent of operation that will be open at any time during the active life ${ }^{15}$ of the facility. The purpose of this estimate is to indicate the largest area of the facility that would need to be closed if the facility were forced to close unexpectedly. At some facilities, the estimate of the maximum extent of operations may be equivalent to the maximum design capacity of the facility. At other facilities, owners or operators may reduce the size of the maximum area ever open at one time by periodically performing partial closures during the course of operations. For example, if no more than two cells of a landfill are ever open at one time, then the maximum extent of operation is two cells.

\subsubsection{Estimate of Meximum Inventory}

The closure plan must include an estimate of the maximum inventory ever on-site over the life of the facility. This estimate should include:

- All hazardous wastes, including residues, from all management units and

- Contaminated soils and residues from routine drips and spills.

The amount of inventory on site should never exceed the estimate in the closure plan. If the owner or operator increases the amount of inventory, he must revise the estimate upwards or justify to the Regional Administrator that the inventory accumulation was caused by an unlikely contingency and that the inventory will be reduced in a short time to levels not exceeding the original estimate. The maximum inventory of hazardous wastes ever on-site should also take into account events such as adverse weather conditions that affect landfilling activities or periods of reduced activities while conducting routine maintenance.

\subsubsection{Treating Remening, or Disposing of the Maximum Inventory}

The closure plan must include a detailed description of how an owner or operator will handle all hazardous wastes during closure. The procedures must be consistent with the estimate of the maximum extent of inventory. An owner or operator may handle the inventory through on-site treatment or disposal or off-site treatment, storage, or disposal.

- On-site Management. Wastes may be handled on-site if capacity will be available (either in the unit to be closed or in another unit at the facility) at the time the unit is closed. The owner or operator may expand or create a new unit at closure if he submits a revised Part $\mathrm{A}$ application and the Regional Administer determines that the increase in design capacity is necessary due to a lack of available capacity, or the changes are necessary to protect human health and the environment, or to satisfy Federal, State or local requirements.

$15 \$ 260.10$ defines "active life" as the period from the initial receipt of hazardous waste at the facility until the Regional Administrator receives certification of final closure. 
Offesite Manugement. The closure plan must include an estimate of the quantity of waste to be sent off-site; a description of any treatment to be performed prior to transport; an estimate of the distance to the final TSDF; and a description of treatment or disposal methods at the final TSDF.

\subsubsection{Fucilizy Decontamination}

The closure plan must describe procedures for decontaminating the facility. This description should include some indication of the extent of contamination at the facility, such as a list of contaminated equipment, structures, and soils, procedures for cleaning equipment, removing contaminated soils, and sampling and testing surrounding soils, and criteria for evaluating decontamination. For example, if the owner or operator is planning to clean close a unit, the closure plan should identify the nature and extent of contamination at the unit, the procedures for eliminating the contamination, and the criteria for determining when the unit is considered "clean". See Section 4.2 for a further discussion of procedures for determining "how clean is clean."

\subsubsection{Ground-Water Monitoring}

Facilities with surface impoundments, landfills, waste piles, or land treatment units must have groundwater monitoring systems in accordance with Part 264 Subpart F (for permitted facilities) and Part 265 Subpart F (for interim status facilities) throughout the active life of the facility, including the partial and final closure period. $^{16}$ The ground-water monitoring activities undertaken during closure and described in the closure plan (as required by 40 CFR $\$ \$ 264.112(b)(5)$ and $265.112(b)(5)$ ) likely will be consistent with the monitoring conducted during the operation of the unit. (See Section 2.1 for more information on ground-water. monitoring).

\subsubsection{Unit-Specific Closure Activities}

Other unit-specific activities necessary to address the closure performance standard may include leachate management, a final cover, gas monitoring, run-on and run-off control, and security provisions. Most of these activities are a necessary part of the operating requirements for a unit or facility and will need to be continued throughout the closure period. These activities are described in greater more detail in Chapter 4.

- Leachate management includes leachate monitoring, collection, removal, and treatment. ${ }^{17}$

- A final cover is necessary for units in which hazardous wastes will remain after closure. A description of the final cover should include drawings, specifications that demonstrate that the cover will satisfy the performance standard, and procedures for cover installation. The specifications of the

${ }^{16}$ In accordance with $40 \mathrm{CFR} \$ 265.90(\mathrm{a})$, interim status waste piles are not required to conduct groundwater monitoring throughout the active life of the facility.

17 Leachate collection systems are required for new units, lateral expansions, and replacement units of existing permitted and interim status landfills, surface impoundments, and waste piles (40 CFR \$\$264.221, $264.251,264.301,265.221,265.251$, and 265.301). 
cover, such as the type of cover materials and the thickness of materials, should also be described.

- Gas monitoring may involve gas collection and control systems for controlling and venting the movement of produced gases.

- Run-on and run-off control may be necessary to ensure that rain or melting snow do not infilltrate or erode the final cover on a unit. The description of run-on and run-of control should identify activities for treating, removing, or disposing, of the excess water that may accumulate from run-on and run-off.

- Security systems must be maintained throughout the closure period unless the owner or operator demonstrates that access of persons or livestock onto the facility will not cause damage to human health or the environment (see \$\$ 264.14 and 265.14). Security devices may include signs with "Danger Unauthorized Personnel Keep Out" notices on them, and fences. The closure plan should specify exactly what type of security devices will be used.

\subsubsection{Partial and Final Closure Schedule}

In accordance with $\$ 264.112(b)(6)$ and $265.112(b)(6)$, the closure plan must include a schedule for closure of each hazardous waste management unit and for final closure of the facility. At a minimum, the plan must include:

- The total time required to close each hazardous waste management unit, and

- The time required for intervening closure activities, e.g., the time required to place a final cover over a landfill unit.

This schedule must be consistent with the closure deadlines imposed by $\$ 264.113$ and 265.113 (discussed in Section 3.1.4 of this guidance manual).

\subsubsection{Amendments to Closure and Post-Closure Plans}

Owners and operators must amend closure and post-closure plans as necessary to remain consistent with facility conditions. Closure and post-closure plans must be amended if:

- A change in operating plans or facility design affects the closure or postclosure plan;

- An unexpected event occurs while conducting closure activities that affects the closure or post-closure plan;

- An unexpected event occurs during the active life that affects the closure or post-closure plan; or 
- There is a change in the expected year of closure for units required to include an expected closure date in the closure plan (i.e., interim status facilities without approved closure plans).

\subsubsection{Notification of Closure}

An owner or operator must notify the Regional Administrator prior to the date he expects to begin closure. These notification deadlines vary according to the type of the unit to be closed and whether the unit is permitted or operating under interim status. 40 CFR $\$ \$ 264.112$ (d) and 265.112(d) specify these deadlines which are summarized in Exhibit 3-3.

Exhibit 3-4 provides a sample format for the notification of closure. For facilities without approved plans, the owner or operator also must submit with the notification of closure the closure plan for approval if it has not already been submitted.

40 CFR \$\$264.112(e) and 265.112(e) allow the owner or operator to remove hazardous wastes and decontaminate or dismantle equipment in accordance with the approved closure plan any time before or after notification of partial or final closure. This allowance enables the owner or operator to eliminate, as quickly as possible, potential threats that may be caused by hazarcous wastes. However, all such activities undertaken must be conducted in accordance with the approved closure plan (or in the case of interim status facilities without approved plans, in accordance with the subsequently approved plan) and EPA retains the authority to ensure that such activities are not inconsistent with the closure regulations.

\subsubsection{Triggers of Closure}

The date on which an owner or operator expects to begin closure, and thus triggers the closure notification requirement, is either:

- No later than 30 days after the date on which any hazardous waste management unit receives the known final volume of hazardous wastes, or

- One year after the date of receipt of the most recent volume of hazardous wastes.

If the owner or operator can demonstrate to the Regional Administrator that the facility has the capacity to receive additional hazardous wastes and that all steps have and will be taken to prevent any threats to human health and the environment, the Regional Administrator may approve an extension to this one-year limit. 


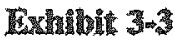

\section{Notification of closure}

Types of Unirs

Notification Deadlines

Perrioted Irocility:

Disposal unit

60 cays prior to unturis closure

Non-Gisposal wait

Wo hotiticasion required unil tonal closure of entire aciulyy

Final closure of disposal acility

60 days mior to final closure

Final closure of non-aisposal racility

45 days prior to ninal closure

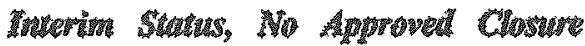

Plare:

Disposal min

180 และ

Non-disposal mit

No notification requited unil fital closure

Final ctosure of disposal bacility

180 days prior to hind closure

Final closure of non-disposal facility

45 days prior to final closure

Intering Stotus, Wuth Approwed Closutre

Plan:

Disposal mint

60 deys prior to untor closure

Non-aisposal mint

No notification requited until final closure

Final closure of disposal facility

60 days prior to final closure

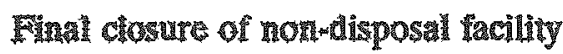


Exhibit 3-4

SAMPLE FORMAT FOR NOTIFICATION OF CLOSURE

Regional Administrator

US EPA, Region

City, State

I am the [owner or operator] of the following hazardous waste management facility [or facilities]:

[Insert name, address, and EPA identification number of each facility]

This letter provides notice, as required under (40 CFR \$\$264.112(d) or 265.112(d)), that I intend to begin closure of the livpe of facility or unit, e.g., surface impoundment, waste pile, etc.] [acility or unit] on [date].

[signature of owner or operator] 
In addition, landfills and land treatment units, and surface impoundments that meet the minimum technical requirements relating to liners and leachate collection systems, may delay closure to receive only nonhazardous waste if the facility owner or operator complies with the following requirements (40 CFR 264.113 and 265.113; see 54 FR 33376, August 14, 1989):

- Submits a permit modification request, or a revised Part B application if the unit has interim status;

- Update facility plans to reflect the continued receipt of non-hazardous wastes (e.g., waste analysis plan and closure plan);

- Continue to comply with all applicable Part 264 and Part 265 requirements, including all closure and post-closure requirements;

- Demonstrate that delaying closure will be protective of human health and the environment; and

- Notify the Regional Administrator and begin closure following the final receipt of non-hazardous waste in accordance with the deadlines in \$\$ 264.112(d) and 265.112(d).

Owners and operators of surface impoundments that were forced to cease receipt of hazardous waste on November 8,1988 , because they did not meet the MTR liner and leachate collection system provisions, may also delay closure of these units if, in addition to the above conditions, they comply with the following:

- Submit a contingent corrective measures plan that addresses procedures for expediting corrective action in the event of a release of hazardous constituents;

- Submit a plan for removing all hazardous liquids and sludges, to the extent practicable without impairing the integrity of the liner(s);

- Remove all hazardous liquids and all sludges to the extent practicable without impairing the integrity of the liner(s) following the final receipt of hazardous waste; and

- Implement corrective measures in the event of a release in accordance with an approved corrective action plan. Continued receipt of nonhazardous waste after the detection of a release is allowed only if the owner or operator has an approved corrective measures plan that demonstrates that continued receipt of waste will not impede the corrective action. The owner or operator may be required to close the impoundment after detection of a release if no substantial progress has been made in the corrective action within a year. 


\subsubsection{Time Allowed for Clasure Activities}

In addition to the deadlines described above for notifying the Regional Administrator that the unit has received its final volume of waste and is ready to be closed, the regulations also impose deadlines for undertaking these closure activities. For all permitted facilities and interim status facilities with approved closure plans, 40 CFR $\$ 264.113$ and 265.113 specify that within 90 days after receiving the final volume of hazardous wastes (or non-hazardous wastes if the unit receives non-hazardous waste after its final receipt of hazardous waste in accordance with $\$ 264.113(d)$ or $265.113(d)$ ), the owner or operator must treat, remove from the unit or facility, or dispose of on-site, all hazardous wastes in accordance with the approved closure plan. For interim status without approved closure plans, the 90-day deadline begins upon the approval of the closure plan if that is later than the final receipt of waste.

The owner or operator must complete the partial or final closure activities in accordance with the approved plan within $\mathbf{1 8 0}$ days after receiving the final volume of hazardous (or non-hazardous, if applicable) wastes. Similarly, for interim status without approved closure plans, the deadline begins with the approval of the plan if that is later than the final receipt of waste.

The Regional Administrator may extend these closure deadlines in the following specific cases:

- The closure activities will of necessity take longer than the allowable time to complete; or

- The hazardous waste management unit has the capacity to receive additional wastes; and

- There is reasonable likelihood that operation of the unit or facility will recommence within one year; and

- Closure of the unit or facility would be incompatible with continued operation of the site.

If, at the time the owner or operator is developing a closure plan, he knows that he will need to exceed the 90 - or 180-day deadline, the owner or operator should include in the closure plan a justification for an extension of the deadline(s).

\subsubsection{Dispesul or Decontamination of Equmipment, Structures and Soils}

$40 \mathrm{CFR} \$ 264.114$ and 265.114 require proper disposal or decontamination of all contaminated equipment, structures and soils during partial and final closure of the facility. If, however, the owner or operator chooses to remove any of the hazardous wastes or hazardous constituents, he would be considered a hazardous waste generator and in such case, would be required to handle the wastes or constituents in accordance with the applicable requirements of 40 CFR Part 262 (i.e., generator standards) and 268 (i.e., land disposal restrictions).

The Subpart G closure regulations do not outline the specific activities that must be followed to ensure that contaminated equipment, structures, and soils are treated or disposed of properly. Nonetheless, the closure plan must describe how these disposal and decontamination activities will proceed. The activities 
described in the closure plan must satisfy the closure performance standard of \$\$264.111 and 265.111. Because drips and spills should be cleaned up as they occur (as a routine maintenance practice), many of the activities that should be included in the closure plan for removing or decontaminating soils should be similar to those conducted during the operating life of the facility as part of routine operations. Decontamination activities should include a description of the criteria for evaluating whether decontamination is complete (i.e., how clean is clean?). These activities are discussed in greater detail in Chapter 4.

\subsubsection{Certification of Closure}

40 CFR $\$ \$ 264.115$ and 265.115 require facility owners or operators to submit a certification signed by the owner or operator and an independent registered professional engineer certifying that closure activities have been conducted in accordance with the approved closure plan. EPA defines an independent engineer as one who is not a direct employee (i.e., not on the payroll) of the facility owner or operator, or the owner or operator himself. Owners or operators of surface impoundments, waste piles, land treatment, and landfill units must submit certifications after closure of each unit. Owners and operators of incinerators, tanks, or container storage areas may submit closure certifications of these units at final closure (i.e., after closure of the last unit at the facility). The closure certification must be sent, by registered mail, to the Regional Administrator within 60 days of the completion of closure.

The certification of closure for a land treatment unit may be signed by an independent qualified soil scientist in lieu of an independent registered professional engineer (40 CFR \$\$264.280(b) and 265.280(e)). The regulations do not specify the type of professional engineer (or soil scientist) that may certify closure. The owner or operator should choose an appropriate professional engineer or soil scientist based on qualifications such as training and experience.

The regulations require that documentation supporting the professional engineer's or soil scientist's certification be furnished to the Regional Administrator upon request. Supporting documentation for nondisposal facilities may include sampling, testing, and analysis results that prove that the closure was complete and that the facility is considered "clean" according to the criteria provided in the closure plan. Because of the many technical factors involved in demonstrating clean closure, such as providing statistically valid soil sampling data, this documentation may be an extensive report. In many cases, EPA Regional staff may request additional sampling information, statistical analyses, and in some cases, additional soil removal.

Facilities should maintain the supporting documentation until the closure certification has been accepted by the Regional Administrator. Disposal facilities, however, are encouraged to maintain the supporting documentation for a longer period of time because information on past practices will be useful if corrective action is required after closure.

Sample certifications are provided as Exhibits 3-5 and 3-6. Exhibit 3-5 is a sample owner or operator closure certification; Exhibit 3-6 is a sample independent registered professional engineer closure certification.

\subsubsection{Survay Plats and Post-Closure Notices}

After closure of each disposal unit (i.e., each unit at which wastes remain in place after closure), owners or operators must submit to the local zoning authority, or to the authority with jurisdiction over local land use, and to the Regional Administrator, a survey plat. This plat must identify the location and 


\section{SAMPLE OWNER OR OPERATOR CLOSURE CERTIFICATION}

The undersigned, (Name of Owner or Operator) a (1) Corporation, incorporated under the laws in the State of and licensed to do business in or (2) (Partnership. Individual, Municipality or Other Entity), with its principal place of business at (Address) which formerly owned or operated a hazardous waste (Description of Hazardous Waste Activity) (hereinafter "Facility") known as (Location) (Name of Hazardous Waste Facility) and located at in County, (State), has completed and permanently ceased the active operation of the facility and has fully implemented all measures relating to the closure of the facility as set forth in the Closure Plan approved by _ (Region or State) for said facility.

NOW, THEREFORE, I(we)

(Name of Owner/Operator) hereby swear and affirm that the above-named hazardous waste facility has been closed in accordance with the facility's Closure Plan approved in writing by (name of Regional Administrator of State Director) on 19- that all measures relating to the closure of the facility required by the Closure Plan and the rules and regulations of (regulatory citation) have been fully implemented, and that to the best of my (our) knowledge, no violations continue to exist that may have arisen prior to closure.

\section{Signature}

(Title)

\section{(Address)}

Taken, sworn and subscribed before me, this day of A.D. 19

(Notary) 
Exhibit 3-6

SAMPLE INDEPENDENT REGISTERED PROFISSIONAL ENGINEER CLOSURE CERTIFICATION

I, (Name) a Professional Engineer registered pursuant to the Professional Engineers Registration Law, , hereby certify that I have reviewed the Closure Plan for the (Type of Facility) at (Name of Hazarclous Waste Facility) ("facility"), located at (Location) that I am familiar with the rules and regulations of (regulatory citation) pertaining to closure of such facility, and that I personally have made visual inspection(s) of the aforementioned facility, and that the closure of the aforementioned facility has been performed in full and complete accordance with the facility's closure plan approved in writing by (Regional Administrator or State Director) on 19 , and the rules and regulations of (regulatory citation).

(Signature)

(Professional Engineering License Number)

(Business Address)

(Telephone Number) 
dimensions of each disposal unit with respect to permanently surveyed benchmarks, and must be prepared by a professional land surveyor. The plat must be submitted no later than the submission of the certification of closure of each disposal unit. The requirement for a survey plat is found in \$\$264.116 and 265.116.

$40 \mathrm{CFR} \$ \$ 264.119$ and 265.119 require owners or operators of disposal units to submit to the local zoning authority, or the authority with jurisdiction over local land use, and to the Regional Administrator, a record of the type, location, and quantity of hazardous wastes disposed of within each disposal unit (e.g.s disposal cell or trench) of the facility. This record must be filed within 60 days after certification of closure of each disposal unit. For mixed waste units, a record of the hazardous components of the mixed waste is necessary.

Also, within 60 days after certification of closure of the first hazardous waste disposal unit and within 60 days after certification of closure of the last hazardous waste disposal unit, the owner or operator must record a notation on the deed to the facility property, noting the following to potential purchasers:

- That the land has been used to manage hazardous wastes;

- That its use is restricted by regulation; and

- That the survey plat and record of wastes have been filed with the land use authorities and the Regional Administrator.

The facility owner or operator must also submit a signed certification to the Regional Administrator after certification of closure of the first and last disposal unit stating that the deed notation has been recorded.

Exhibit 3-7 provides a sample deed notation.

\subsection{THE SUBPART G POST-CLOSURE CARE REQUIREMENTS}

The post-closure care requirements are included in $40 \mathrm{CFR} \$ \$ 264.117-264.120$ for permitted facilities and \$\$265.117-265.120 for interim status facilities. These closure requirements apply to the owners and operators of:

- All hazardous waste landfills, disposal surface impoundments, and land ireatment unit; and

- Tank systems, waste piles, and surface impoundments that cannot remove or decontaminate all waste residues, contaminated soils, materials, components, subsoils, and structures, and must be closed as a landfill.

Because the hazardous waste component of radioactive mixed waste is subject to RCRA Subtitle C regulation, owmers and operators of mixed waste facilities must comply with the post-closure requirements of $40 \mathrm{CFR}$ Subpart $\mathrm{G}$ for the hazardous component of the mixed waste. 
TO WHOM IT MAY CONCERN:

I, (owner or operator) the undersigned, of

\section{(street address)}

City of

$\rightarrow$ County of State of hereby give the following notice as required by 40 CFR $\$ \$ 264.119$ or 265.119 :

1. I am, and since 19_ have been in possession of the following described lands (legal description)

2. Since 19, I have disposed of hazardous chemical wastes under the terms of regulations promulgated by the United States Environmental Protection Agency on/in the above-described land.

3. The future use of the above-described land is restricted under the terms of 40 CFR Subpart G: the post-closure use of the property must never be allowed to disturb the integrity of either the containment system or the facility's monitoring system, unless the Regional Administrator or State Director determines that the proposed use (1) will not increase the potential threat to human health or the environment, or (2) is necessary to reduce the threat to human health or the environment.

4. Any and all future purchasers of this land should inform themselves of the requirements of the regulations and ascertain the amount and nature of wastes disposed of on/in the above-described property.

5. I have filed a survey plat with the (name and address of local land authority) and with the Regional Administrator of EPA, Region (*) (or State Director, State of ), at (address of Regional Administrator or State Director) showing the location and dimensions of landfill cells and a record of the type, location and quantity of waste disposal within each area of the facility. 


\subsubsection{Length of the Post-Closure Period}

The regulations require 30 years of post-closure care for each disposal unit, beginning after completion of closure of the unit. The Regional Administrator has the authority to shorten or extend the length of the posi-closure care period, if he finds that altering the length of the period is sufficient or necessary, respectively, to protect human health and the environment. In addition, the owner or operator or any member of the public may petition the Regional Administrator to alter the length of the post-closure care period ( $40 \mathrm{CFR}$ $\$ \$ 124.5(\mathrm{a}), 265.118(\mathrm{~g}), 270.41$, and 270.42$)$. If the owner or operator believes that an extension or reduction in the length of the period will be necessary for a unit, he should include a justification for the alternative length of post-closure care in the post-closure plan.

Because the regulations do not specify the criteria that must be used to determine whether to alter the length of the post-closure care period, such decisions are based on site-specific facility conditions. For example, if some disposal units at a facility close earlier than other units, unless each unit has its own separate ground-water monitoring system, the Regional Administrator may extend the length of the post-closure care period for the units that closed earlier because of the interrelationship of the monitoring system.

Broad technical evaluation criteria and site-specific technical factors that should be considered when evaluating the appropriate length of the post-closure care period follow:

- Containment -- How long will the unit or facility contain the wastes after closure?

- Detection -- Will the systems currently in place at the unit or facility detect releases of hazardous waste?

- Migration and Attenuation -- Will the wastes migrate off site, and will the leachate be attenuated in the environment?

- Risk Potential -- Who potentially will be exposed to a waste release, how toxic are the waste constituents, and consequently, what risks are involved?

- Facility Characteristics -- Examples include process type, facility design, waste management (operational) practices, and corrective action activities.

- Waste Types and Characteristics - Waste characteristics are defined by the physical and chemical properties of the wastes, including degradability, volatility, solubility, adsorptivity, bioaccumulation, kinematic viscosity, and toxicity.

- Environmental and Health Considerations -- Includes information about the unsaturated zone (soil), the saturated zone (ground water), topography and geography, and climatological conditions. 


\subsubsection{The Post-Closure Plan}

All hazardous waste disposal units must have a written post-closure plan, in accordance with $40 \mathrm{CFR}$ $\$ \$ 264.118$ and 265.118 , describing the activities that will be conducted after closure of each disposal unit and the frequency of these activities. Exhibit 3-8 provides an overview of the activities that must be described in the post-closure plan and the regulatory citation for each requirement.

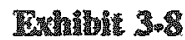

Post-Closure Plan Reruturements

Contents of the Postuclosure Plan

Reguilatory Citation

Monioring activities and their $\$ 8264.118(b)(1)$ and $265.118(c)(1)$ irequency

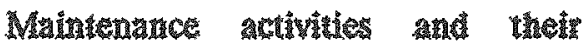
frequency

Identification of contat person or office

\$8264.118(b)(2) and 265.118(c)(2)

$\$ \$ 264.118(b)(3)$ and $265.118(\mathrm{c})(3)$

In addition, $\$ \$ 264.118(\mathrm{~b})$ and $265.118(\mathrm{~b})$ reference the technical post-closure care requirements that are described in detail in Chapter 4 of this document. The information necessary for inclusion in the plan varies depending on the type of unit. Since predicting with complete accuracy all the activities that will be necessary at a unit or facility for a period extending 30 years after closure may be extremely difficult, the owner or operator may wish to include a wide range of possible activities in the post-closure plan to reduce the future likelihood of having to modify the facility permit or the approved post-closure plan. The information presented below represents the minimum information necessary in a post-closure plan.

\subsubsection{Monitoring Activities}

The monitoring activities described in the post-closure plan should be consistent with the current conditions at the unit or facility. Monitoring activities should include ground-water monitoring activities (e.g., number, location, and depth of wells; frequency and procedures for sampling; types of analyses), soil monitoring, leak detection monitoring, and gas monitoring, as appropriate. If the monitoring activities described in the post-closure plan are not consistent with the current conditions at the facility (i.e., if monitoring activities will differ during the post-closure period), then the owner or operator should include in the plan an explanation of the reasons for the change. 


\subsubsection{Maintenance Actividies}

The owner or operator must include in the post-closure plan a description of the maintenance activities that will be conducted at the unit or facility throughout the post-closure care period, and the frequency with which these activities will be conducted. The maintenance activities described must include those activities necessary to ensure the integrity of the hazardous waste containment systems and the function of the monitoring equipment. The plan should include a description and schedule of the following types of activities:

- Routine Faciling Inespections, including inspections of the final cover, run-on and run-off control system, surveyed benchmarks, ground-water monitoring system, leachate collection system, leak detection system, unsaturated zone monitoring system, and security system, as applicable.

- Maintenunce of Wuste Conainment Systems, including mowing, fertilizing, reseeding and mulching eroded areas, sprinkling, replacing soil lost to erosion, maintaining drainage channels and culverts which direct surface runon and run-off away from the disposal area and prevent surface water from infittrating the cover, and controlling rodents as necessary to counter infestations.

- Maintencuce of the Monitoring Systems, including replacing or redrilling monitoring wells, replacing seals, piping, and caps, repairing or replacing pumps, and other kinds of routine equipment maintenance.

- Lenchase Manggement including procedures for collecting, handling, and disposing of leachate during the post-closure care period. In most cases, leachate management procedures are a continuation of activities conducted during the operating life of the unit. For example, if leachate is routinely collected in a tank for periodic removal, the plan should estimate the quantity of leachate to be removed and specify how it will be treated or disposed.

- Maintenance of the Security Systom (e.g., fences, warning signs), if applicable ${ }^{18}$, including, for example, replacement of sections of fences due to normal wear, severe weather conditions, and vandalism, and periodic replacement of warning signs for similar reasons.

- Continutution of Hazardous Waste Degradation at Land Treatment Fracilumies, including disking, fertilizing, liming to ensure proper pH balance, irrigating, controlling run-on and run-off from the treatment fields, repairing erosion

18 Some disposal units or facilities will be required by the Regional or State office to maintain security devices throughout the post-closure period. The post-closure plan should describe such security or provide supporting justification for why such provisions are not needed to ensure the protection of human health and the environment. 
damage, regrading and replanting as needed, and controlling wind dispersal of particulates.

\subsubsection{Conture Person or Office}

40 CFR $\$ 264.118(b)(3)$ and $265.118(c)(3)$ specify that the post-closure plan must identify the name, address, and phone number of the person or office to contact about the disposal unit or facility during the post-closure care period. The identification of this contact person serves to ensure that access to the facility will be possible after closure and in the case of emergency.

\subsubsection{Centification of Completion of Post-Closure Caure}

$40 \mathrm{CFR} \$ \$ 264.120$ and 265.120 require that within 60 days after the completion of the 30 -year postclosure care period for each landfill, surface impoundment, land treatment unit, or other unit required to closure as a landfill (e.g., waste pile or tank), the owner or operator must submit a certification to the Regional Administrator that post-closure care was completed in accordance with the approved post-closure plan. The certification requirements (e.g., signed by the owner or operator and an independent registered professional engineer) are the same as the certification of closure discussed previously in Section 3.1.7. Postclosure certifications are not required annually; rather they are required at the end of the entire post-closure care period for each unit.

The independent registered professional engineer will have to rely on a review of the documents generated by the unit or facility during the post-closure care period (e.g., inspection reports, ground-water monitoring results, invoices for maintenance activities) and a visual inspection of the unit or facility to certify adequate completion of post-closure care. These documents, the engineer's account of the visual inspection, and potentially a summarization report of the engineer's findings would be considered supporting documentation for the certification and should be maintained by the owner or operator.

As with the certification of closure, the regulations also require that documentation supporting the professional engineer's certification be furnished to the Regional Administrator upon request. Facilities should maintain any supporting documentation (e.go, information regarding activities conducted during inspections, field reports documenting each on-site visit, in-house records that were reviewed) until the Regional Administrator accepts the post-closure certification.

\subsection{CONTINGENT CLOSURE/POST-CLOSURE PLANS}

The Subpart G regulations require an owner or operator of certain tank systems, surface impoundments, and waste piles to prepare a contingent closure plan and post-closure plan describing closure activities that will be necessary if it is not possible to remove all wastes at closure and the unit must be closed as a landfill. This contingent closure plan is in addition to the standard closure plan describing clean closure activities (40 CFR \$\$264.228(c)(1), 264.258(c)(1), 264.197(c)(1) and (2), and 265.197(c)(1) and (2)).

The types of units subject to the contingent closure plan requirements are:

- Permitted storage surface impoundments and waste piles that are not designed in accordance with the specified liner design standards of 40 CFR 
$\$ \$ 264.221$ (a) and 264.251(a) (e.go, synthetic liners), and that are not exempt from these design standards, and

- Permitted and interim status tanks that do not have secondary containment and that are not exempt from the secondary containment requirements.

Owners or operators of surface impoundments that failed to satisfy the November 8,1988 , HSWA deadline to meet the MTRs for surface impoundments (and were not granted an exemption from the standards) and thus were required to cease the receipt of hazardous wastes, are required to include a contingent closure and post-closure plan in their plan submissions.

Surface impoundments and waste piles may be exempted from the liner design standards if the facility owner or operator adequately demonstrates to the Regional Administrator that an alternate design and operating practice, together with location characteristics, will prevent the migration of any hazardous constituents into the ground water or surface water at any future time. Similarly, tanks may be exempted from secondary containment requirements if the facility owner or operator adequately demonstrates to the Regional Administrator that an alternate design and operating practice, together with location characteristics, will prevent the migration of any hazardous waste or hazardous constituents into the ground water or surface water as least as effectively as secondary containment during the active life of the tank system or that in the event of a release that does not migrate to ground water or surface water, no substantial present or potential hazard will be posed to human health or the environment. Underground tanks, however, may not be exempted from the secondary containment requirement through such a demonstration.

Owners or operators of surface impoundments, waste piles, and tanks not subject to the contingent plan requirements must amend their closure plan, prepare a post-closure plan, and comply with the postclosure care regulations if the owner or operator or Regional Administrator determines that the unit must be closed as a landfill. These plans should closely resemble closure and post-closure plans of landfills and any of the preceding units closed as a landfill must comply with all the landfill specific closure and post-closure care standards contained in $40 \mathrm{CFR} \$ \$ 264.310$ and 265.310 . 
REFERENCES: CHAPTER 3

OSWER Policy Directive \#9476.00-5, "Draft RCRA Guidance Manual for Subpart G Closure and Post-closure Care Standards and Subpart H Cost Estimating Requirements, "U.S. EPA, January 1987. 


\section{TECHNICAL REQUIREMENTS FOR CLOSING HAZARDOUS AND MIXED WASTE UNITS}

This chapter presents the technical requirements for closing hazardous and mixed waste units at DOE facilities. General management and procedural requirements for mixed waste units are located in Chapters 2 and 3 respectively. For each of the RCRA-regulated hazardous waste management units, this chapter provides detailed guidance on the preparation of closure and post-closure plans (where appropriate), on technologies and procedures for conducting closure activities, on activities to be conducted in demonstrating closure, and on activities to be conducted during the post-closure period for each unit. In addition, it outlines the statutory and regulatory requirements pertaining to the closure of each unit, to make it clear which requirements are mandatory rather than recommended guidance.

This chapter is organized into nine separate sections, each one addressing an individual RCRAregulated hazardous waste management unit. Exhibit 4-1 outlines the organization of this chapter in greater detail.

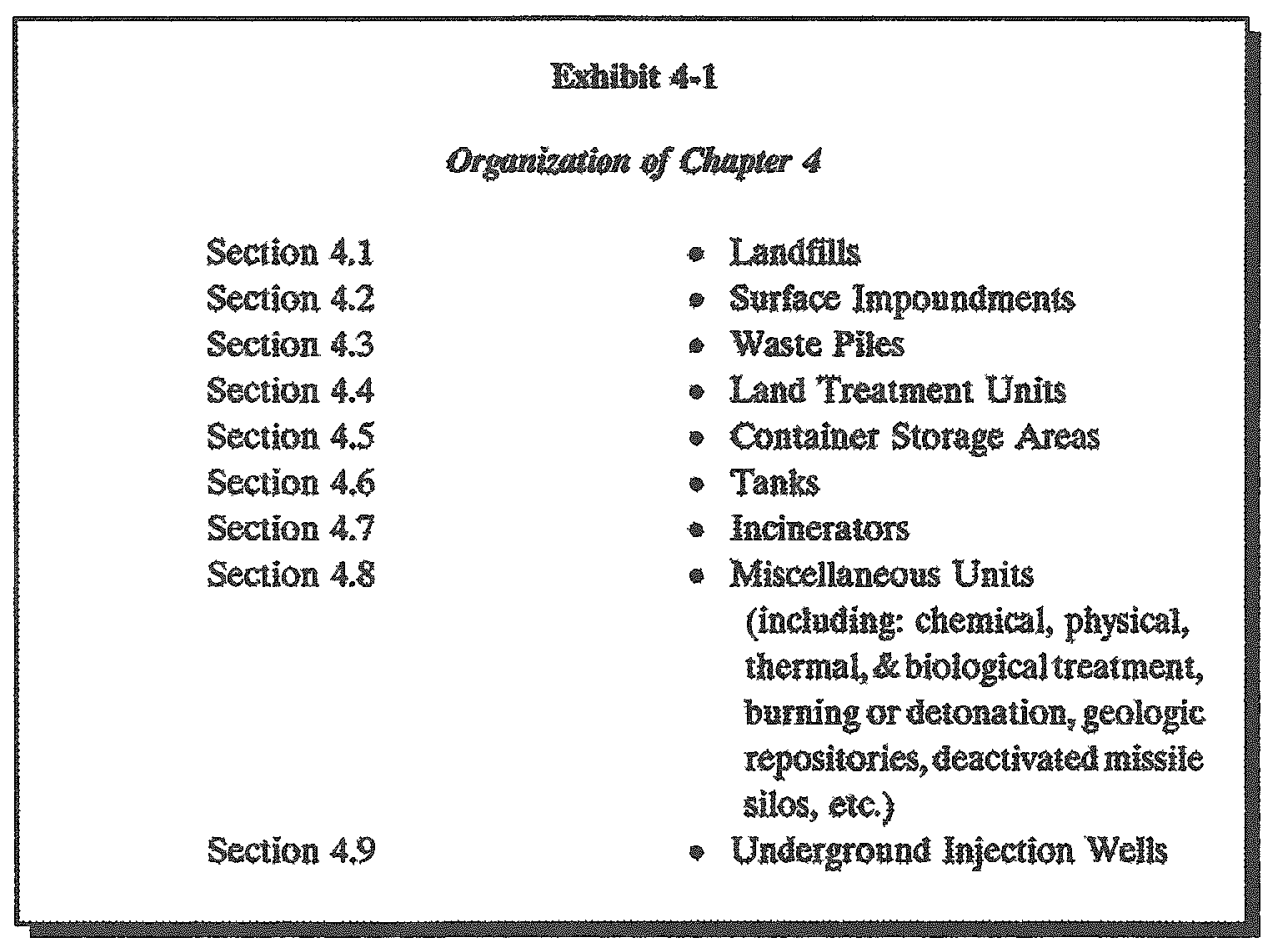

These sections are intended to provide both an overview of the applicable requirements and detailed technical information on the closure of each type of unit. While each of the nine sections are largely independent, many of them reference the discussions on Landfills (Section 4.1) and Surface Impoundments (Section 4.2). These sections explain in greater detail the procedures for conducting landfill closures and clean closures, respectively, components of which are relevant to closing other units. 
Given the complexity of closure activities, this chapter should not be used as a "cookbook" for conducting closures. In order to assist DOE personnel and contractors, this chapter includes numerous EPA and periodical references, where appropriate, that provide more detailed information than can be presented in one manual. 


\section{LANDFILLS}

This section presents the requirements for closure and post-closure care of landfills containing hazardous and radioactive mixed wastes located at DOE facilities. A hazardous waste landfill is defined in 40 CFR \$260.10 as a disposal facility or part of a facility where hazardous waste is placed in or on land and which is not a pile, a land treatment facility, a surface impoundment, an underground injection well, a salt dome formation, a salt bed formation, an underground mine, or a cave. A landfill commonly consists of a number of cells, which are defined (in $40 \mathrm{CFR} \$ 260.10$ ) as discrete volumes of a hazardous waste landfill which use a liner to provide isolation of wastes from adjacent cells or wastes. Some examples of landfill cells are trenches and pits.

\subsubsection{What Are the Closure Requirements for Landfills?}

Exhibit 4.1-1 provides an overview of the key closure requirements for landfills and references to where in this section more detailed information is provided.

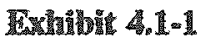

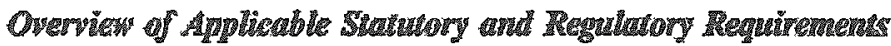

The owner or operator must prepare a witten closure plan describing at closure activities for landinil units.

Section 4.1.2.1

Each landill unit must be closed woth a fanal cover that meets specined design and performance standards.

Section $4.1 .2 .2-4.1 .2 .5$

The owner or operator must prepare a witten post-closure care plan and conduct post-closure care, including ground-water monitoring, for 30 years.

Section $4.1 .2 .6 \cdot 4.1 .2 .7$

\subsubsection{Srausurory Requirements}

Section 3005(i) of RCRA states that interim status units that have received hazardous or mixed wastes since July 26,1982 , must conduct corrective action and ground-water monitoring activities that apply to new facilities. Therefore, interim status landfills (that have received waste since July 26,1982 ) that undergo closure must comply with the monitoring and corrective action requirements for permitted units. 
An overview of the relevant ground-water monitoring and corrective action requirements for closure is located in Chapter 2 of this manual; ground-water monitoring and corrective action regulatory requirements are found in 40 CFR Parts 264 and 265, Subpart F.

\section{A.1.1.2 Reguldatory Requirements}

The regulatory requirements for closure of hazardous waste landfills are found in 40 CFR Parts 264 and 265, Subpart $\mathrm{N}$. Under these hazardous waste management regulations, owners or operators of facilities with landfills are required to perform "landfill closure."19 The landfill closure performance standards of $\$ \$ 264.310$ and 265.310 require the owner or operator to design and construct a low-permeability cover over the unit to minimize the migration of liquids into the waste. In addition, the owner or operator must provide 30 years of post-closure maintenance and care for the unit in order to prevent waste or constituent migration into the environment. The owner or operator must have written closure and post-closure plans that identify the steps necessary to perform closure of the landill and maintain it after closure.

EPA's landfill closure performance standards and post-closure requirements apply to both interim status and permitted units. Because interim status landfill units that received waste prior to May 8,1985 , are not required to have a double liner and a leachate collection and removal system, continued collection of leachate during the post-closure period is required only of permitted units. Otherwise, the closure and postclosure requirements are identical for permitted and interim status units.

\subsubsection{Closure of Landfills}

The technical requirements for closure of hazardous waste landfils are found in 40 CER $\$ 264.310$ and 265.310 (for permitted and interim status units, respectively). These requirements are expressed as a performance standard that provides for the long-term minimization of leachate generation and the control of contaminant migration into the environment. The primary requirement for landfill closure is the design and construction of a final cover.

The following activities are required for closure of a hazardous waste landfill:

- Prepare closure plan (Section 4.1.2.1);

- Design final cover (Section 4.1.2.2); and

- Conduct closure (Sections 4.1.2.3 - 4.1.2.5).

These activities are discussed in detail in the subsections that follow.

\subsubsection{Preparing Landfill Closure Plans}

A written closure plan is required for closure, as described in Chapter 3 of this manual. An outline of a sample closure plan for a landfill is presented in Exhibit 4.1-2. As indicated in the exhibit, the closure

19 This type of closure is also an option for the closure of other land disposal units (i.e., surface impoundments, waste piles). 
plan should include detailed information about facility and waste characteristics, plans for decontamination and/or disposal during closure, final cover design, ground-water monitoring, security systems, survey plats, closure certification, and the schedule of partial and final closure.

EPA's "Permit Applicants' Guidance Manual for Hazardous Waste Land Treatment, Storage, and Disposal Facilities," Final Draft, May 1984, EPA-530-SW-84-004 recommends that an analysis of the final cover design be presented in the basic portion of the closure plan and that details be provided in an attachment on "cover design." This EPA guidance suggests that the analysis of the final cover design should describe how the proposed design minimizes liquid migration, promotes drainage while controlling erosion, minimizes maintenance needs, accounts for potential settlement and subsidence, has a permeability equal to or less than the permeability of the bottom liners or natural subsoil, and accounts for freeze/thaw effects. Specific information related to the design of the final cover that this EPA guidance recommends for inclusion in the plan consists of:

- Detailed drawings of the proposed layers;

- Common name, species, and variety of the cover crop;

- Description of the synthetic liner in the final cap, including the type of liner, its chemical properties, and manufacturer specifications for thickness and strength;

- Description of any protective materials placed above or below the synthetic liner;

- Characterization of any clay liner placed beneath the synthetic liner, including thickness and permeability;

- Construction plans for any clay liner;

- Analysis of surface drainage and discussion of erosion control;

- Procedures for installing each layer, with emphasis on the installation of the synthetic membrane; and

- Specifications of the drainage layer, including hydraulic conductivity.

The closure plan should also include results from consolidation tests performed on soil samples, data on potential settlement due to consolidation of the liner and foundation soils, compression of the landfill material, and biological oxidation of organics. These demonstrations should include all the raw data, assumptions, construction plans, and drawings that are necessary to support the analysis provided in the plan. 
Exhibit 4.1-2

LANDFILI, CLOSURE PLAN SAMPLE OUTLINE

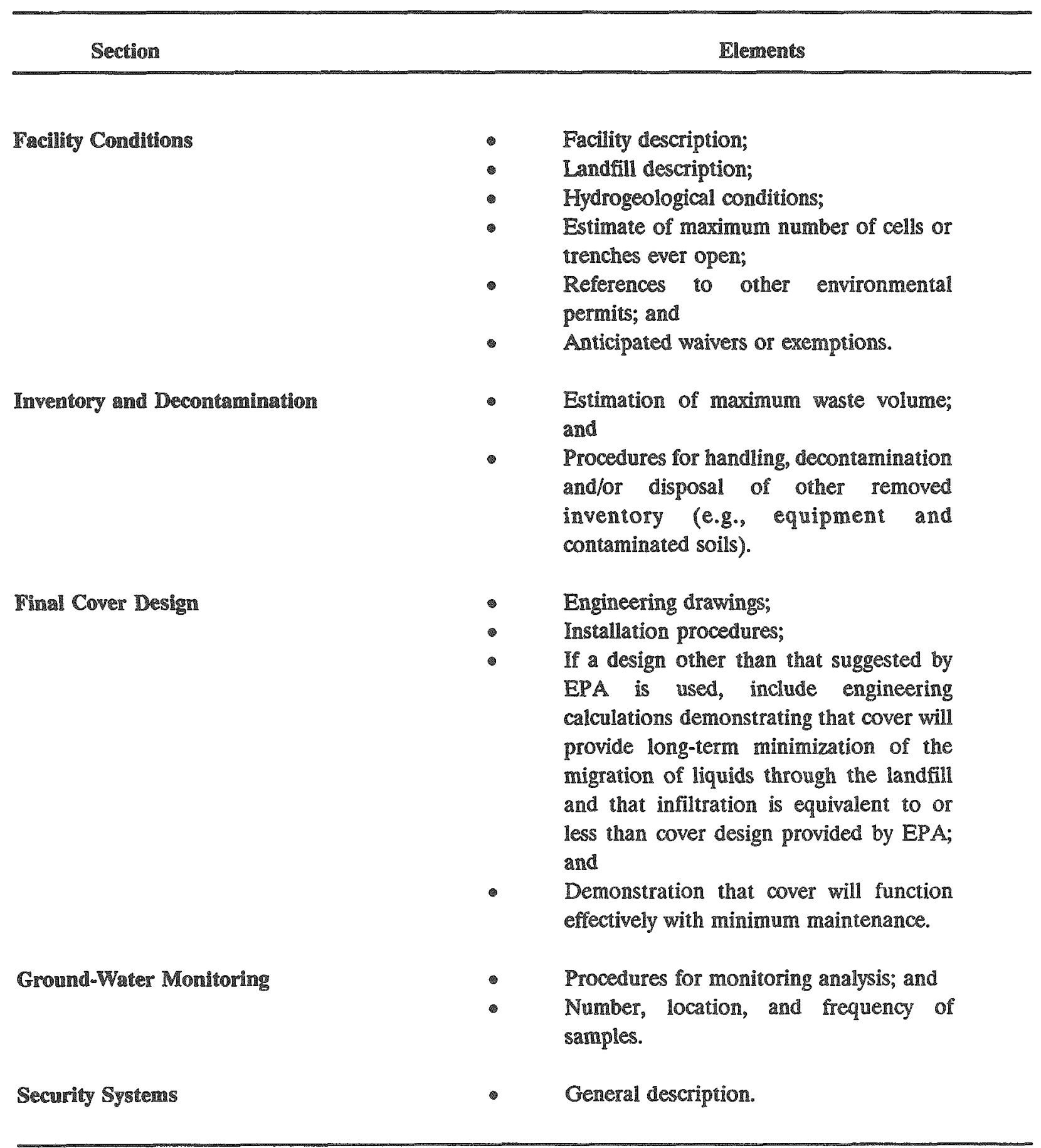


Exhibit 4.1-2 (Continued)

LANDFILI CLOSURE PLAN SAMPLE OUTLINE

\begin{tabular}{|c|c|}
\hline Section & Elements \\
\hline Survey Plat & Surveyed benchmarks. \\
\hline Closure Certinication & $\begin{array}{l}\text { Activities to be conducted; and } \\
\text { Documentation. }\end{array}$ \\
\hline Schedule of Partial \& Final Closure & $\begin{array}{l}\text { Expected year of closure (oniy for interim } \\
\text { status facilities without approved closure } \\
\text { plans); } \\
\text { Frequency of partial closure(s); } \\
\text { Time required for waste treatment, } \\
\text { removal, decontamination, and final } \\
\text { closure; and } \\
\text { Support for deadline extensions, if } \\
\text { applicable. }\end{array}$ \\
\hline
\end{tabular}

Source: OSWER Policy Directive No. 9476.00-5, "RCRA Guidance Manual for Subpart G Closure and Post-Closure Care Standards and Subpart H Cost Estimating Requirements (Draft)". 


\subsubsection{Designing Final Landfill Covers}

At closure, a final cover must be placed on a landfill to minimize long-term infiltration of precipitation and rum-off into the closed landfill. This final cover must be designed and constructed to meet or exceed the performance standard stated in EPA's regulations. As discussed later in this section, it may be appropriate to design covers that also meet NRC standards for mixed waste facilities (see Appendix D). Exhibit 4.1-3 below presents the performance requirements for the design and construction of a final cover for a hazardous waste landîll under $40 \mathrm{CFR} \$ \$ 264.310(\mathrm{a})$ and $265.310(\mathrm{a})$.

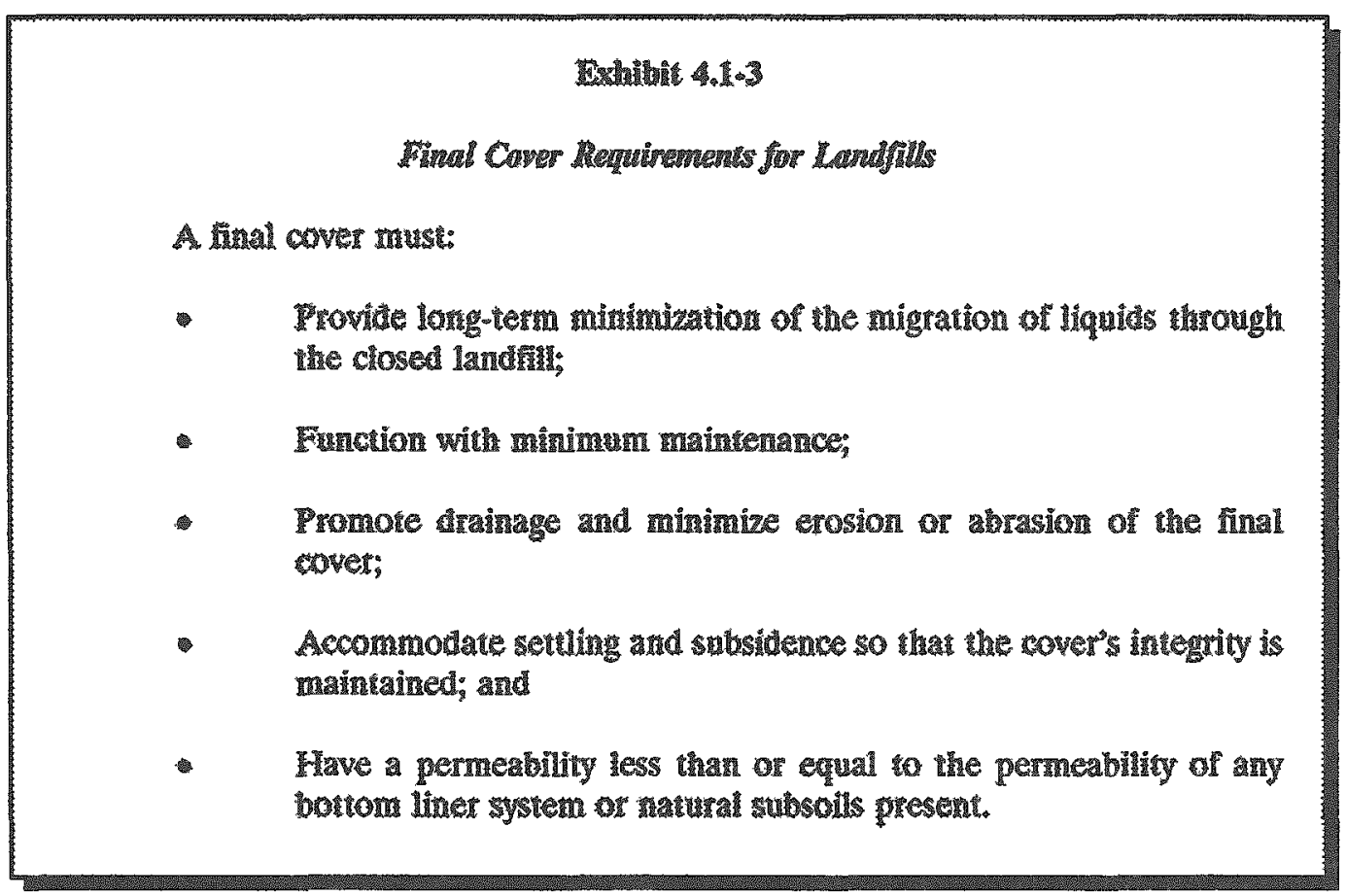

These cover requirements are performance standards that allow some flexibility in design. Final covers must be designed with a permeability equal to or less than the permeability of the bottom liner system or natural subsoils. This is to prevent the "bathtub effect, "i.e., the liquid buildup and eventual overflow due to precipitation which enters the unit through the cover but can not escape through the bottom liner. In addition, the standards require that covers minimize erosion or abrasion and accommodate settling and subsidence. Several guidance documents on interpreting the regulatory requirements for final covers and on their design are available from EPA, including:

- Technical Guidance Document: Final Covers on Hazardous Waste Landfills and Surface Impoundments, "EPA/530-SW-89-047, July 1989;

- "Evaluating Cover Systems for Solid and Hazardous Waste," EPA\# SW-867, GPO\# 055-000-00228-2, 1982 (This manual provides a guide to examining soil, topographical, and climatological data and recommends cover evaluation procedures.); 
- "Design and Constmuction of Covers for Solid Waste Landfills," EPA-600/2-79-165, August 1979; and

- "Covers for Uncontrolled Hazardous Waste Sites," EPA/540/2-85/002, September 1985.

- "Seminar Publication, Requirements for Hazardous Waste Landfills: Design, Construction, and Closure," EPA 625/6-88/022, August 1989.

When closing a landfill that contains mixed waste, the owner or operator may face additional considerations related to minimizing leachate generation and testing and handling of leachates. Guidance on these mixed waste leachate considerations may be found in the following NRC/EPA guidance document (see Appendix D):

- "Joint NRC.EPA Guidance on a Conceptual Design Approach for Commercial Low-Level Radionctive and Hazardous Waste Disposal Facilities," August 3, 1987.

EPA'S Recommended Final Cover Design. EPA's technical guidance for final covers, referenced above, describes a recommended cover design that will meet the final cover performance standard. However, because the final cover design described in this guidance is only recommended, any design that can be demonstrated to meet or exceed the regulatory performance standard can be used in place of the recommended system. EPA's recommended cover is comprised of three layers: a top layer, a drainage layer, and a low permeability layer. Exhibit 4.1-4 illustrates the components of the recommended cover system. The three layers of the recommended cover system are described in detail below.

The two-component top loyer consists of an upper vegetative layer (or other surface treatment) underlain by soil. The upper component should be designed to impede erosion while allowing surface runoff from major storms. Unless the prevailing climate precludes the use of vegetation because of difficulty in establishing or maintaining vegetative cover, EPA recommends that this upper component consist of locally adapted perennial plants with the following characteristics:

- Resistance to drought and temperature extremes;

- Roots which will not disrupt the low-permeability layer;

- Ability to thrive in low-nutrient soil with minimal nutrient additions;

- Sufficient density to minimize cover soil erosion to no more than 2 tons/acre/year;, 20 and

- Ability to survive and function with little or no maintenance.

In environments where it is not practical to maintain vegetation of this nature, EPA recommends that armoring material be used in place of vegetation as the upper component of the top layer. Armoring material should possess the following characteristics:

20 Calculated using the USDA Universal Soil Loss Equation (USLE). 
Truhibit 4.1-4

\section{EPA'S RECOMMENDEO THREE-IAYER COVER SYSTEM}

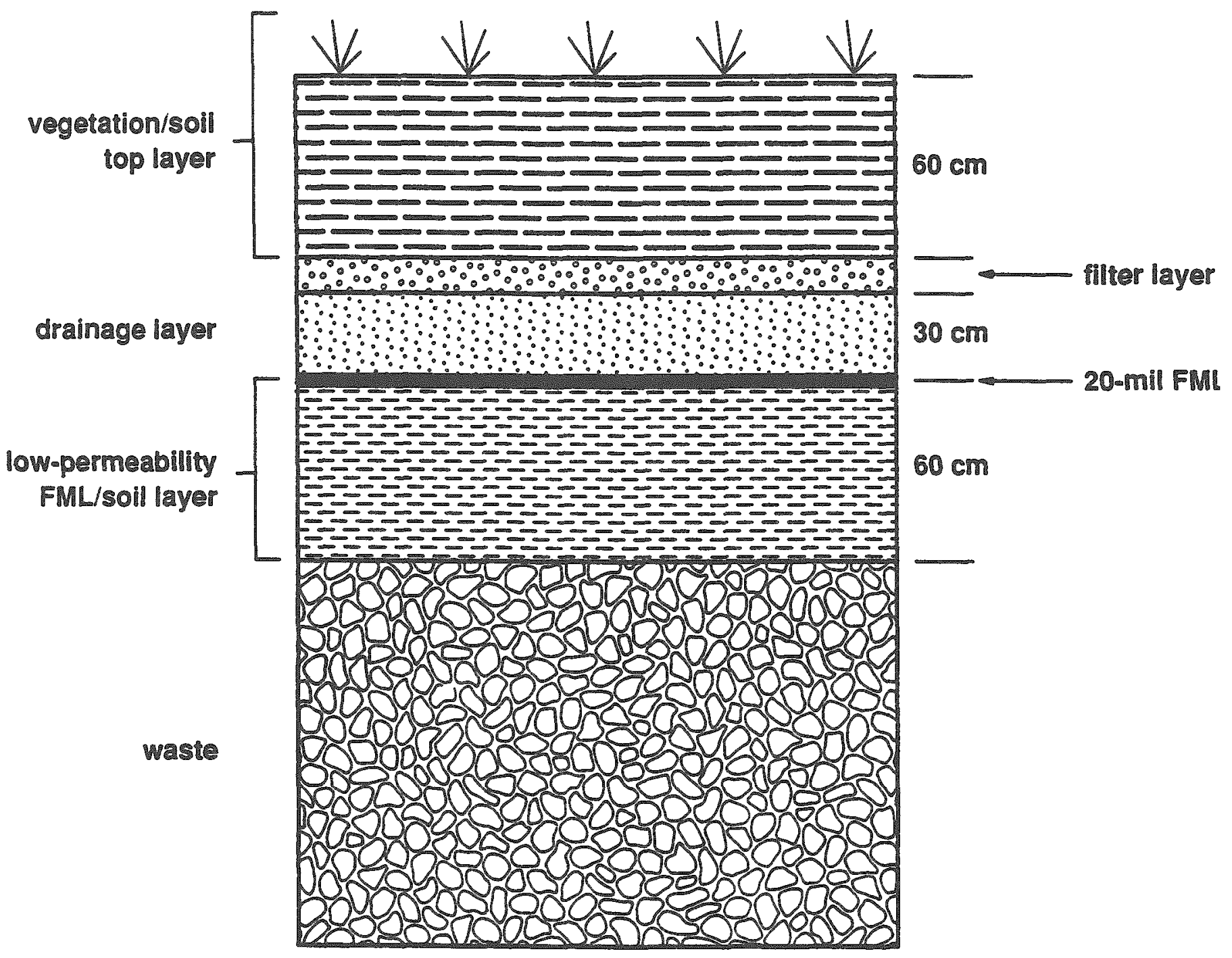

Source: EPA/530-SW-89-047, "Technical Guidance Document: Final Covers on Hazardous Waste Landfills and Surface Impoundments," July 1989. 
- Ability to minimize water and wind erosion of itself and the underlying soil during severe weather and to control the annual rate of soil erosion of the cover to no more than 2 tons/acre/year (calculated using the USLE);

- Ability to accommodate settlement without compromising performance; and

- A surface slope approximately the same as the underlying soil (at least a 3 percent slope).

EPA recommends that the lower component of the top layer have the following characteristics:

- A minimum thickness of $60 \mathrm{~cm}$ (24 in.), including $15 \mathrm{~cm}$ (6 in.) of topsoil (to support vegetation);

- Medium texture (to support seed germination and root development);

- A final top slope, after allowance for settling and subsidence, of at least 3 percent, but no greater than 5 percent (to assist run-off while minimizing erosion); and

- Minimum compaction (to support root development and sufficient infiltration to maintain plant growth during dry periods).

EPA's "Technical Guidance Document: Final Covers on Hazardous Waste Landfulls and Surface Impoundments," $J u l y 1989$ provides a more detailed discussion of this layer as well as references to assist in the choice of appropriate vegetation or other erosion-impeding materials. Use of the USLE to estimate annual erosion rates is described briefly in the section below.

The drainage layer is intended to promote the rapid and efficient transport of water from the cover to an exit drain. Water that infiltrates through the top layer should be removed from the cover by the drainage layer, thus minimizing the amount and residence time of water coming into contact with the lowpermeability layer. The drainage layer can be comprised of either granular material such as sand or of geosymthetic materials. The Agency recommends that a granular drainage layer (e.g., sand) have the following characteristics:

- A minimum thickness of $30 \mathrm{~cm}$ (12 in.) and a minimum slope at the bottom of the layer of 3 percent, or greater slope and/or thickness if necessary as determined by hydrologic modeling (see discussion below on using the Hydrologic Evaluation of Landfill Performance [HELP] model to demonstrate compliance with the performance standard);

- Hydraulic conductivity of no less than $1 \times 10^{-2} \mathrm{~cm} / \mathrm{sec}$ (at the time of installation);

- A maximum particle size of $3 / 8$ inch, classified by the Unified Soil Classification System as a SP sand (i.e., smooth and rounded containing no debris that might damage the underlying membrane liner); and

- Overlain by a filter layer, granular or geosynthetic, between the top layer and the drainage layer to prevent clogging of the drainage layer. 
If the drainage layer is composed of geosynthetic materials, EPA recommends the following characteristics:

- The same minimum flow capability as a granular drainage layer (i.e., a hydraulic transmissivity of $3 \times 10^{-5} \mathrm{~m}^{2} / \mathrm{sec}$ or greater);

- A geosynthetic filter layer above the drainage material to prevent clogging of the drainage layer by soil material; and

- A geosynthetic bedding beneath the drainage layer, if necessary, to provide sufficient friction to minimize slippage between the drainage layer and the underlying membrane and to prevent intrusion of the membrane into the drainage layer.

The low-permeability layer provides the cover system with a permeability of less than or equal to the permeability of the landfill's bottom liner system or natural subsoils present. This layer should be placed at a depth below the maximum frost penetration depth and consist of, at least, an upper flexible membrane liner (FML) component and a bottom soil component. EPA recommends an upper FML component which has the following characteristics:

- At least 20 mils thick;

- A minimum 3 percent slope;

- An even surface (i.e., without local depressions);

- Material and seam specifications such as those required for liners;

- Protection by an overlying drainage layer (as described above);

- Direct contact with the underlying compacted soil component; and

- A minimal number of properly sealed, designed penetrations (e.g., gas vents), no stressed conditions, and no excessive slack.

The bottom soil component should have the following characteristics:

- $60 \mathrm{~cm}(24 \mathrm{in}$ ) of compacted, low-permeability soil (in-place saturated hydraulic conductivity of $1 \times 10^{-7} \mathrm{~cm} / \mathrm{sec}$ or less);

- Free of clods, rocks, stone, debris, cobbles, rubbish, roots, etc.;

- An upper surface with a slope of 3 percent; and

- Constructed entirely below the maximum frost penetration depth upon completion of the cover system.

Designing Equivalent Covers. EPA recognizes that its recommended cover system may not be appropriate for all landfill units or all sites, and that alternative cover designs may fulfill the regulatory performance standard for final covers. Alternative designs must provide long-term performance at least 
equivalent to the recommended design including, minimizing infiltration and providing resistance to erosion and abrasion at least as well as the analogous layers of the recommended cover system. Alternative designs should also require minimal maintenance and be as durable as the recommended system. Exhibit 4.1-5 below discusses minimum requirements for alternative cover designs.

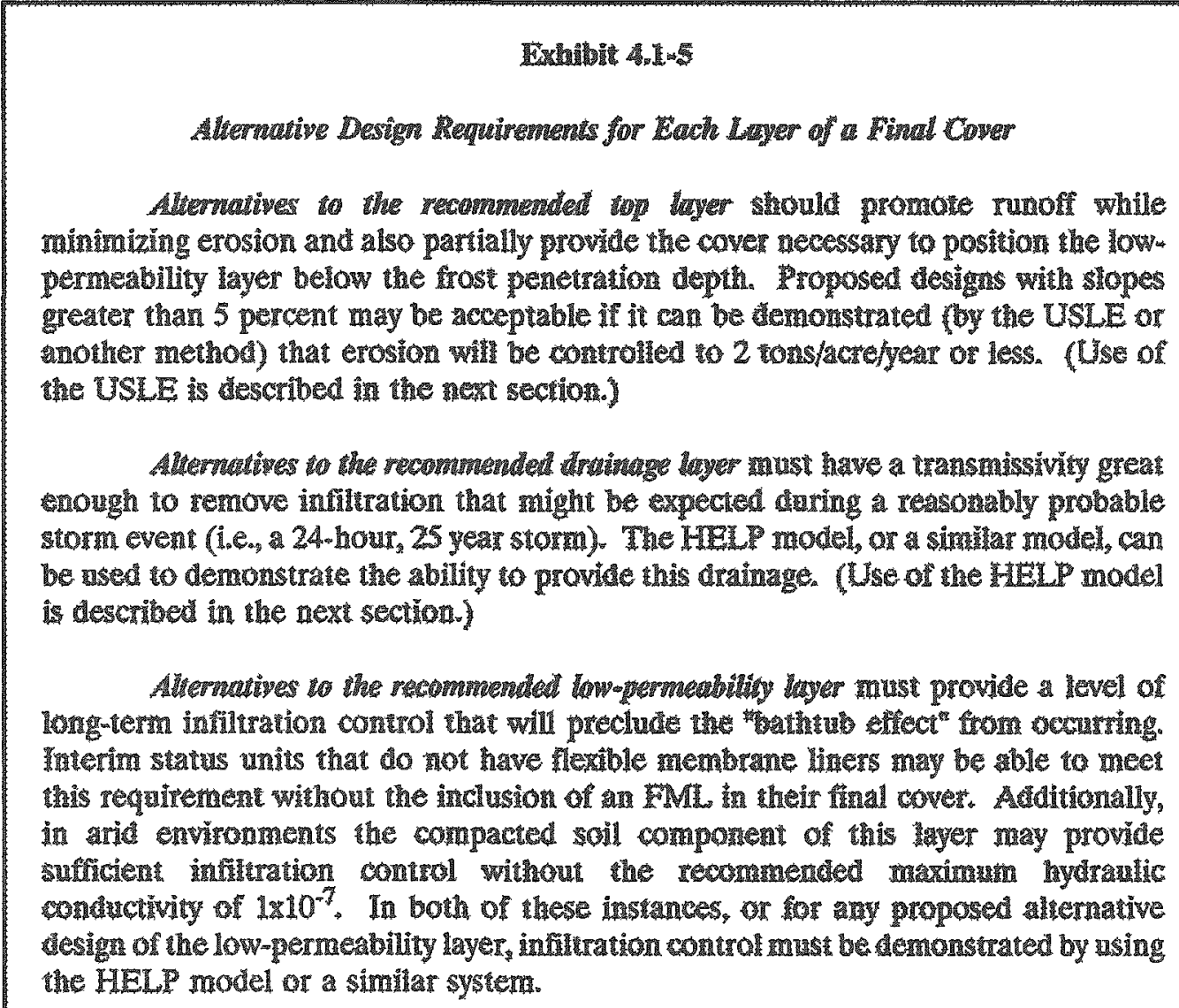

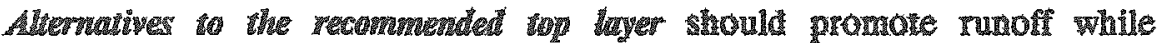
miminizing erosion and also partially prowide the cover necessary to position the lowpermeability layer below the frost penetration depth. greater than 5 percent may be acceptable if i can be temonstrated foy the USLE or

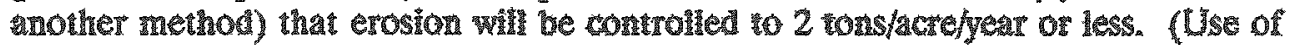
ohe USLE is (xescribed in the next section.)

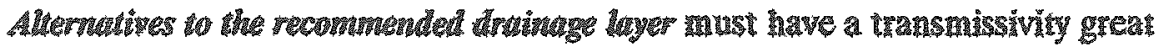

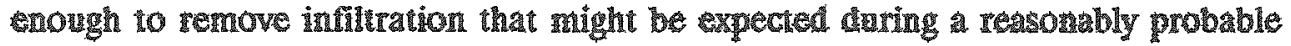

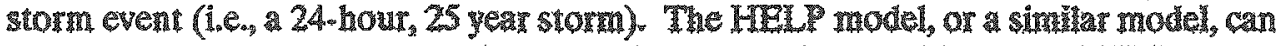
be ased to demonstrate the ability to provide this drainage. (Use of the HELP model is described in whe next section-)

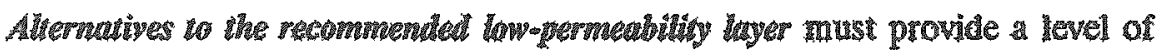

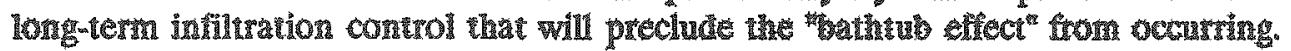
Interim status units that do not have plexible membrane liners may be able to meet this regairernent withont the inclusion of in arid environments the compacted soil componerat of this tayer may provide sufficient infituration control without the reconmented maximum hydrantic

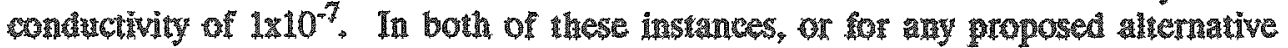
cesign of the low-permedibility layer, infituration control an the HELP model or a similar systern.

Demonstrating Compliance with the Performance Sterullard. In order to demonstrate that the proposed final cover design complies with the regulatory performance standard, it may be necessary to model the hydrologic performance and erosion potential of the proposed cover. Data demonstrating that the proposed cover design will prevent the collection of water in the closed unit (the "bathtub effect") also must be provided in the closure plan. EPA suggests that the HELP model be used for these demonstrations (User's Guide for the Hydrologic Evaluation of Landfill Performance (HELP) Model," EPA/530-SW-84-009). ${ }^{21}$ Exhibit 4.1-6

21 The mainframe version of the HELP model is maintained on the National Computer Center (NCC) IBM Computer System. A PC version is also available. Contact National Technical Information Services (NTIS) at (703) 487-4807 to obtain an NCC account. The U.S. Army Engineer Waterways Experiment Station (WES) can answer questions regarding the use of the model (mainframe or PC version), establish the model on your NCC account, or send you the PC version of the model. Contact WES at (601) 634-3709 (commercial) or 542-3709 (FTS). 
below briefly describes this model and its recommended use for demonstrating the hydrologic performance of a final cover.

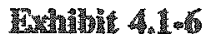

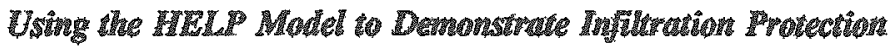

\section{Description of the MrELE Madel}

The Hydrologic Evaluation of Landfill Periormance (HELP) model estimates the anounts of surface runof, subsurface discharge, and leachate that may be expected to result from the operation of a wide wariety of possible landfill designs. The model

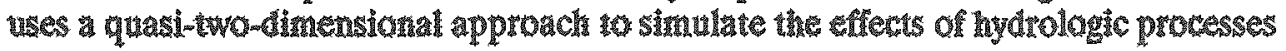
such as precipitation, surface storage, runofi, infiltation, percolation,

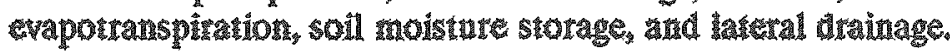

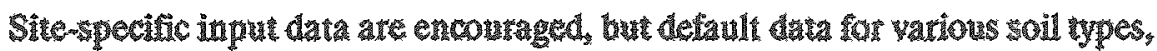
geographic areas, mnd vegetation types are avallable. Output is avallable lor daily results, monthly totals, antual average rotals, and average montuly totats. Average monthly totałs and annual average totals tor precipingtion, runofi, evapotrenspiration,

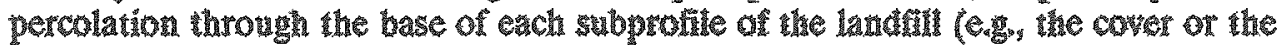
waste and liner), and lateral drainage from each subrofile are provided.

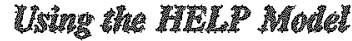

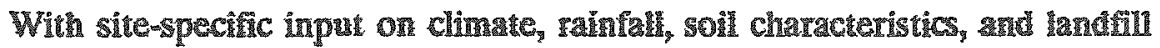

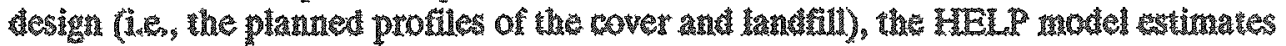

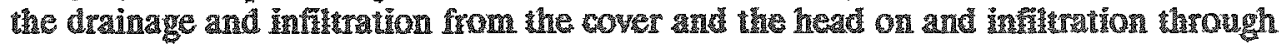

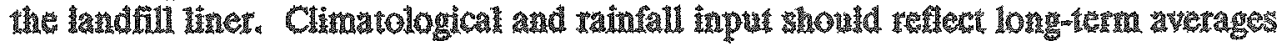
and model outpu should describe infiltration control (e.ges adeguate dränage and

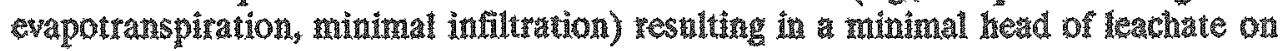
the bottom line over a long-duration modeling periad.

Data demonstrating that the proposed design will not result in excessive erosion of the cover may be needed to support the choice of the slope and surficial cover material (vegetative or armoring). Guidance on using the USLE to assess erosion potential is described in EPA's "Evaluating Cover Systems for Solid and Hazardous Waste," Report No. SW.867, 1982 and "Design and Construction of Covers for Solid Waste Landjulls," EPA-600/2-79-165, August 1979. EPA's "Technical Guidance Document: Final Covers on Hazardous Waste Landfills and Surface Impoundments," July 1989 recommends a slope of between 3 and 5 percent or a demonstration by the USLE that total erosion will be less than 2.0 tons/acre/year. Exhibit $4.1-7$ below describes the USLE and its application to estimating the erosion potential of landfill covers. 
Exhabit 4.117

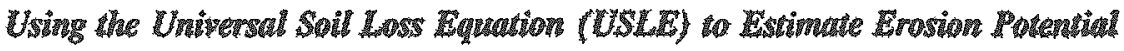

Deseription of the USLE

factors:

The USUL estimates anumal arerge soil loss as a function of six site-\$pecific

$$
\begin{aligned}
& A=\text { RILSCP, } \\
& \text { A sverage innual swil loss (tons/acre), }
\end{aligned}
$$

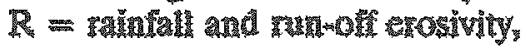

$$
\begin{aligned}
& \text { K } \text { - soll erodalitity actor (tons/acre), } \\
& L=\text { slope-length factor, } \\
& S \text { slope-steepnes hetor, }{ }^{2}
\end{aligned}
$$

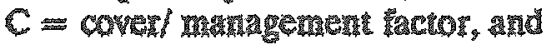

$$
\begin{aligned}
& \mathbb{P}=\text { practice arcior. }
\end{aligned}
$$

UTing

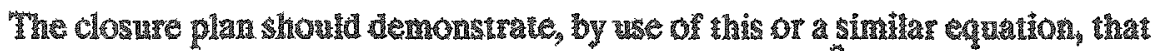

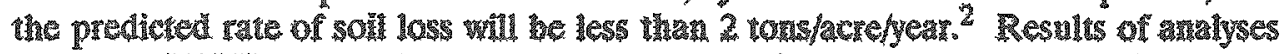

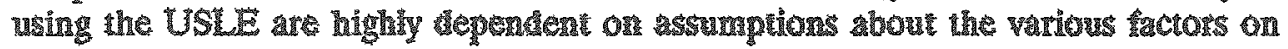
which the rate of soil los depends. EPA provides gaidance on determinating vatues for these actors in "Derigg and Construction of Covers for Sold Waste Landfilts" EPA-

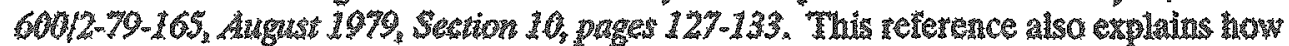

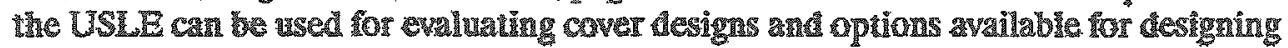
water asion control.

1 The USLE is derived from antal on slopes up to 18 degrees. Use of the equation for steeper slopes tay a ho be appropriate.

Optional Cover System Features. In addition to the cover system features discussed above, some situations will require the addition of other features to the cover system. Two relatively common optional cover components include a gas venting system and a biotic barrier.

If the landfilled waste is likely to produce gases, it is advisable to install a gas venting system above the waste layer during closure to prevent future build up of pressure under the final cover. Generation of gases is most likely in units containing significant quantities of organic waste materials. EPA's "Technical Guidance Document: Final Covers on Hazardous Waste Landfills and Surface Impoundments," July 1989 recommends that a gas venting layer, installed between the waste and the low permeability layer of the cover, should have the following characteristics: 
A minimum thickness of $30 \mathrm{~cm}(12 \mathrm{in}$.$) ;$

(2)

Composed of coarse-grained porous materials (similar to a drainage layer), or if geosynthetic materials are used, equivalent performance 10 a granular system must be demonstrated;

- Venting to an exterior collection point for disposal or treatment, provided by laterally pattemed, horizontal perforated pipes channeled to vertical risers which extend through the cover; and

- A minimal number of vertical risers located at high points of the cover.

Further information on the design of gas venting layers is provided in EPA's "Design and Construction of Covers for Solid Waste Landfills," EPA-600/2-79-165, August 1979.

If deep plant roots or burrowing animals may threaten the integrity of the proposed cover, it is advisable to include a biotic barrier layer in the cover design. EPA's "Technical Guidance Document: Final Covers on Hazardous Waste Landfills and Surface Impoundments," EPA/530-SW-89-047, July 1989 recommends the use of physical barriers to discourage or reduce threats of plants or animals to the performance of the cover. The recommended design calls for either three feet of cobbles or six inches of gravel over two and onehalf feet of cobbles. This layer should lie directly under the soil component of the top layer of the cover (perhaps separated by a filter layer). Further information on protecting covers from biological intrusions can be found in:

- Hakonson, T.E., "Evaluation of Geologic Materials to Limit Biological Intrusion into Low-level Radioactive Waste Disposal Sites," Los Alamos National Laboratory Report LA-10286-MS, February 1986;

- Hakonson, T.E., J.F. Cline, W.H. Rickard, "Biological Intrusion Barriers for Large Volume Waste Disposal Sites," in Proceedings. Low-Level Disposal: Facility Design, Construction, and Operating Practices, NUREG/CP-0028, CONF 820911, Vol. 3, U.S. Nuclear Regulatory Commission, Washington, D.C., 1983; and

- Foxx, T.S., G.D. Tierney, J.M. Williams, "Rooting Depths of Plants on Low-Level Waste Disposal Sites," Los Alamos National Laboratory Report LA-10253-MS, November 1984.

\subsubsection{Preparing a Lawdill for Installation of a Cover}

Before construction of a landfill cover can begin, the landfill should be properly prepared for installation of the cover. The two primary steps in preparing the landfill are (1) compacting the waste to the maximum degree practical and (2) installing a foundation layer. 
Waste Compaction - Setring and Subsidence. Because landfilled waste can be prone to settlement and subsidence, $^{22}$ it may be necessary to stabilize the landfill as much as possible by compacting the waste. To minimize the detrimental effects of an unstable (spongy) base for a cover, EPA's "Design and Construction of Covers for Solid Waste Landfills," EPA-600/2-79-165, August 1989 recommends that a conservative .waste compaction effort be conducted prior to cover construction. This guidance suggests, as an example, that four passes of equipment over the waste be used as a first cut until experience indicates a change is warranted. Additional practical and theoretical information on settlement and subsidence are provided in the following EPA reports:

- "Settlement and Cover Subsidence of Hazardous Waste Landfills," EPA-600/2-85/035, 1985;

- "Prediction/Mitigation of Subsidence Damage to Hazardous Waste Landfull Covers," EPA/600/2-871025, 1987; and

- Covers for Uncontrolled Hazardous Waste Sites," EPA/540/2-85/002, September 1985.

When a significant amount of settlement and subsidence is expected within two to five years, EPA's "Technical Guidance Document: Final Covers on Hazardous Waste Landfills and Surface Impoundments," EPA/530-SW-89-047, July 1989 proposes that interim covers may be appropriate. After settlement occurs, a final cover could be built atop the interim cover, or the interim cover could be replaced with a final cover. An interim cover must meet the general performance standards of 40 CFR \$264.111.

The "Joint NRC-EPA Guidance on a Conceptual Design Approach for Commercial Low-Level Radionctive and Hazordous Waste Disposal Facilities," August 3, 1987 suggests that, when closing landfills containing mixed wastes, it may be acceptable to place wastes in high integrity waste containers (HICs). Spaces between containers would then be filled with a cohesionless, low compressible fill material. In such a case, compaction may be necessary. Other options include placement of wastes in an engineered reinforced concrete vault, steel fiber polymer impregnated concrete vault, or double-lined high integrity containers that are hermetically sealed. Appendix $D$ includes technical information regarding appropriate designs for mixed waste disposal facilities subject to NRC and EPA requirements. Although NRC requirements do not apply at DOE facilities, the guidance contained in these two materials may be applied to mixed waste disposal units as appropriate.

Foundation Layer. Prior to cover construction, a foundation layer may be installed to provide (1) support for the cover, (2) sufficient strength and rigidity to support the compaction of the low-permeability layer, and (3) proper bedding material for the lower, soil component of the low-permeability layer. EPA's "Handbook: Remedial Action at Waste Disposal Sites (Revised), EPA1625/6-85/006, October 1985 recommends that this layer be installed in 6-inch lifts over the waste and compacted to its maximum achievable density to increase its strength. This guidance suggests that the ability of this layer to support the cover and cover construction process be evaluated using the following tests:

22 Settlement refers to uniformly distributed recession of the landfill due to compression of the foundation, liner, or waste or the dewatering of the waste. Settlement may primarily occur prior to cover construction. Subsidence refers to unevenly distributed settlement after closure. Subsiaience can threaten the integrity of a cover by creating cracks and depressions. 
- unconfined compressive strength tests (by ASTM D2166),

- triaxial compression tests (by ASTM D2850),

- direct shear tests (by ASTM D3080), and

- grain size analyses (by ASTM D421, D422, and D1140).

Achievement of the desired compaction is primarily a function of the compactive effort and the water content of the soil at the time of compaction. For a discussion of these variables and their control to optimize compaction of a foundation layer, refer to EPA's "Covers for Uncontrolled Hazardous Waste Sites, "EPA/540/2851002 , September 1985.

EPA's "Handbook: Remedial Action at Waste Disposal Sites (Revised)," EPA/625/6-85/006, October 1985 also suggests that the base underlying the low-permeability layer be composed of fine to medium grade fill that will not abrade the liner. This base, or foundation layer, must be sufficiently fine-grained to prevent the fine grains of the compacted soil portion of the low-permeability layer from falling into the foundation layer. Appropriate grain sizes for the foundation (bedding) layer are specified in "Evaluating Cover Systems for Solid and Hazardous Waste, "EPA, Report Number SW-867, 1982. Altematively, a fabric filter of suitably fine mesh can be placed between the two layers.

\subsubsection{Installation of a Lasufful Cover}

Once a suitable foundation has been established for the cover, installation can begin. A cover is installed by following these steps:

- Placing and compacting the soil component of the low-permeability layer;

- Placing and seaming the Flexible Membrane Liner (FML);

- Placing and compacting the drainage layer (including filter components);

- Placing the soil component of the top layer; and

- Seeding the surface of the cover or placing the armoring material.

In addition, any optional layers specified in the design should be placed (and compacted as needed).

The soil component of the low-permeability layer should be placed in 6-inch lifts and compacted with appropriate equipment (e.g., bulldozer, sheepsfoot roller). EPA's "Handbook: Remedial Action at Waste Disposal Sites [Revised]," EPA/625/6-85/006, October 1985 recommends that this component should be compacted to over 90 percent of its dry density at its optimum water content as determined by ASTM D1557 or another suitable test method. The permeability of this layer should be tested at least wice each acre for each lift. Results of the compaction and permeability tests determine the type of compaction equipment and the number of passes needed. The remainder of the cover should be constructed as soon as possible after completion of this layer to prevent excessive drying (or wetting from precipitation) of this layer.

The FML should be placed and seamed according to the cover design and manufacturer specifications. This component can be spread by hand or machine and seamed by a variety of methods. EPA's "Covers for Uncontrolled Hazardous Waste Sites," EPA/540/2-85/002, September 1985 provides a discussion of the advantages and disadvantages of the various approaches to these operations. 
A granular drainage layer should be placed in six-inch lifts and compacted to an appropriate degree. The permeability and compaction of this layer should be tested to assure compliance with design specifications. If called for in the cover design, a geosynthetic drainage layer can be placed directly atop the FML. Alternatively, a geosynthetic bedding layer might need to be lain between the FML and the drainage layer component. After placement (and compaction) of the drainage component of this layer, the filter layer can be placed (and compacted if necessary). If the filter layer is composed of granular material, it should be placed in lifts, compacted, and tested to demonstrate appropriate compaction and permeability.

The top layer is constructed by spreading the soil component evenly over the drainage layer and seeding this layer with the selected cover vegetation. This layer should not be overly compacted. Seeding, and possibly mulching, should take place as soon as possible after this layer is spread in favorable weather conditions.

\subsubsection{Construction Quality Assuercunce}

EPA recommends that a Construction Quality Assurance (CQA) program be implemented for the purposes of ensuring that the final cover system meets all design criteria, plans, and specifications. Technical guidance on CQA programs has been provided by the EPA and is available in EPA-530/SW-85-021, "Construction Quality Assurance for Hazardous Waste Land Disposal Facilities, Public Comment Document" (1985). Section 2.3 .7 of that document specifies construction inspection activities for overseeing the construction of final cover systems. That section is summarized in the paragraphs below.

Preconstruction. Preconstruction quality assurance activities include screening materials for the system components and constructing test fills to assure that the cover design and manufacturers ${ }^{\prime}$ specifications are met. In addition, the presence of adequate quantities of topsoil, fertilizer, soil conditioners, and seeds of the quality specified in the cover design should be verified. Before closure, experimental plots of proposed cover vegetation might be planted to demonstrate its viability under expected conditions.

Construction. The construction of each component of the final cover should be observed and evaluated with respect to conformance with the specifications of the cover design. Inspection of the foundation layer should include:

- Inspection of subcomponents that are installed into the waste or foundation layer (e.g., gas vents); and

- Testing and observation of the thickness, coverage, slope, density, and bearing strength to check conformance with the design.

Inspection of the low-permeability layer soil component should include:

- Evaluation of test fills to demonstrate achievement of required permeability and to determine the relationship between soil density, moisture content, compactive effort, and permeability;

- Testing of seals around penetrations (e.g., gas vent pipes and leachate collection system standpipes); 
- Survey of surface slope to assure conformance with design and absence of depressions; and

- Inspection of surface conditions with respect to suitability as base for the FML.

Inspection of the FML should include:

- Checking delivery tickets and manufacturers' quality control documents;

- Observing placement of the FML to assure conformance with the plan;

- Observing that seaming is conducted according to the plan and that weather conditions are suitable;

- Testing seams; and

- Inspecting the installation of anchors and seals (around penetrations).

Inspections of the drainage layer should include:

- Observing the filling process around vents and standpipes to prevent their damage or misalignment;

- Inspecting thickness and slope for conformance to cover design; and

- Observing the placement of the filter layer for conformance to cover design.

Inspections of the top layer should include:

- Monitoring the uniformity of the application process;

Inspecting thickness and slope for conformance to cover design;

- Observing that penetrations are not disturbed by placement or tilling; and

- Observing the seeding process, including rate of seed and mulch application, amount and uniformity of coverage, and watering.

\subsubsection{Preparing Post-Closure Care Plans}

Owners or operators of landfills are required to conduct post-closure care for 30 years after closure and must comply with all post-closure procedural requirements contained in $40 \mathrm{CFR} \$ \$ 264.117$ through 264.120 and $\$ \$ 265.117$ through 265.120 , including maintenance and monitoring throughout the post-closure care period.

Provisions for the kinds of monitoring and maintenance activities that reasonably can be expected during the post-closure care period must be specified in a post-closure plan. A post-closure plan should describe, at a minimum, the frequency and scope of inspections; procedures for making repairs to the cover; 
procedures for maintaining run-on and run-off controls; procedures for leachate collection, removal, and treatment; the frequency of sampling and monitoring; maintenance of monitoring systems; and maintenance of surveyed benchmarks. Exhibit $4.1-8$ presents an outline of a sample post-closure care plan.

Exhibit 4.1-8

LANDFILL POST.CLOSURE CARE PLAN SAMPLE OUTLINE

Section

Elements

Ground-Water Monitoriagg

Soll Monitoring

Leachate Monitoring and Removal

Inspections

Maintenance Activities
- Number, location, and depth of wells;

- Frequency of sampling; and

- Types and procedures for analysis.

- Number and frequency of samples;

- Sampling procedures; and

- Types of analysis conducted.

- Frequency and procedures for monitoring;

- Estimated quantity of leachate;

- Procedures for collection and removal of leachate; and

- Leachate treatment and disposal procedures.

- Frequency and

- Scope

- Final cover;

- Monitoring systems; and

- Security systems.

Source: OSWER Policy Directive No. 9476.00-5, "RCRA Guidance Manual for Subpart G Closure and PostClosure Care Standards and Subpart H Cost Estimating Requirements (Draft)". 


\subsubsection{Post-Closure Care Requirements for Landfill Closures}

The post-closure care period is 30 years from the date of closure, unless the Regional Administrator establishes an alternate period. The regulatory requirements for post-closure care of hazardous waste landfills (40 CFR $\$ \$ 264.310(b)-(c)$ and $265.310(b)-(c))$ are summarized in Exhibit 4.1-9.

Exhihinit 4.1.9

\section{Past-Chosutre Cone Requirements Jor Landfiex}

At final closure, the owner or operator must comply with all post-closure requirenents in 40 CFR 85264.17 - 264.120 and 265.117 - 265.120 as well as the following:

- Maintain the integrity and effectiveness of the funal cover, including makting repairs to the cap as necessary to corred the effects of setuting, subsidence, erosion, or other evens:

- Contune to operate the leachate collection and temoval system until leachate is no longer detected for interim status units, this Tequirement is triggered upon issuance of the post-closure permitt)

- Maintain and monitor the ground-water monitoring \$ystem and comply with all other applicable requirements of Subpars $F$ of this Part;

- Prevent rum-on and run-at from eroding or othenwise vamaging the final cover; and

- Protect and maintain surveyed benchmarks used in complying witz 40 CFR \$264.309 (refers to surveying and recota keepting).

During the post-ciosure cure period for permitted landill, defection system installed under 40 CFR $\$ 264.302$ in accordance with the HSWA amendments, the owner or operator must notify the Regional Administrator of the teal within seven days. The Regional Administrator will modify the permit to require compliance with the requitements of Subpart F of Part 264.

The frequency of monitoring and maintenance activities is dependent on the specific site conditions, i.e., climate, waste type, soil, vegetation, etc. For units containing radioactive mixed wastes, the RCRA requirement to collect and remove leachate will require special consideration to ensure that exposures to personnel are kept as low as practicable.

EPA's ground-water monitoring requirements are described in Section 2.1.3.2. In addition to these specific requirements for landfill closure, all other gencric Subpart $G$ closure and post-closure care requirements also apply to the closure of landfills. These general requirements are discussed in Chapter 3. 
In addition to the unit-specific closure requirements discussed in this section, the owner or operator should also be aware of the following additional RCRA requirements.

- Corrective Action. Corrective action at facilities handling mixed waste may be required as a part of, or concurrently with, closure activities. See Section 2.1.3.2 for a discussion of corrective action requirements.

- Land Disposal Restrictions (LDRs). LDRs prohibit the land disposal of RCRA hazardous wastes beyond certain statutory dates established by Congress in HSWA. Restricted hazardous wastes and contaminated soils removed at closure are subject to LDRs. See Section 2.1.4 for a discussion of the LDR program.

- Delisting. If the owner or operator of a facility is able to delist the hazardous component of a mixed waste at closure, the waste is no longer subject to the requirements under RCRA. The delisted material becomes a radioactive waste regulated solely by the DOE. However, delisting a waste does not necessarily exempt the facility that handled the waste from RCRA closure requirements. See Section 2.1.2.5 for a discussion of delisting petitions. 
DOE 5484.1, "Environmental, Safety, and Health Protection Information Reporting Requirements," February 24, 1981.

EPA/530-SW-84-004, "Permit Applicants' Guidance Manual for Hazardous Waste Land Treatment, Storage, and Disposal Facilities," Final Draft, May 1984.

EPA/530-SW-84-009, "User's Guide for the Hydrologic Evaluation of Landfill Performance (HELP) Model." EPA/530-SW-85-021, "Construction Quality Assurance for Hazardous Waste Land Disposal Facilities, Public Comment Document," 1985.

EPA/SW-867, "Evaluating Cover Systems for Solid and Hazardous Waste," 1982 (GPO\#055-000-00228-2).

EPA/530-SW-88-028, "RCRA Corrective Action Plan," Interim Final, June 1988 (OSWER Directive 9902.3).

EPA/530-SW-88-029, "RCRA Corrective Action Interim Measures Guidance," Interim Final, June 1988 (OSWER Directive 9902.4).

EPA/530-\$W-89-047, "Technical Guidance Document: Final Covers on Hazardous Waste Landfills and Surface Impoundments," July 1989.

EPA/540/2-85-002, "Covers for Uncontrolled Hazardous Waste Sites," September 1985.

EPA/600/2-79-165, "Design and Construction of Covers for Solid Waste Landfills," August 1979.

EPA/600/2-85-035, "Settlement and Cover Subsidence of Hazardous Waste Landills," 1985.

EPA/600/2-87-025, "Prediction/Migration of Subsidence Damage to Hazardous Waste Landfill Covers," 1987.

EPA/625/6-85-006, "Handbook: Remedial Action at Waste Disposal Sites (Revised)," October 1985.

EPA/625/6-89-022, "requirements for hazardous waste Landfills: Design, Construction, and Closure," August 1989.

EPA/625/4-89-020, "Corrective Action: Technologies and Applications," September 1989.

Foxx, T.S., G.D. Terney, J.M. Williams, "Rooting Depths of Plants on Low-Level Waste Disposal Sites," Los Alamos National Laboratory Report LA-10235-MS, November 1984.

Hakonson, T.E., "Evaluation of Geologic Materials to Limit Biological Intrusion into Low-level Radioactive Waste Disposal Sites," Los Alamos National Laboratory Report LA-10286-MS, February 1986.

Hakonson, T.E., J.F. Cline, W.H. Rickard, "Biological Intrusion Barriers for Large Volume Waste Disposal Sites," in Proceedings, Low-Level Disposal: Facility Design, Construction, and Operating Practices, NUREG/CP-0028, CONF 820911, Volume 3, U.S. NRC, Washington, D.C., 1983.

"Joint NRC-EPA Guidance on a Conceptual Design Approach for Commercial Low-Level Radioactive and Hazardous Waste Disposal Facilities," August 3, 1987. 
OSWER Policy Directive 4476.00-5, "Draft RCRA Guidance Manual for Subpart G Closure and Post-closure Care Standards and Subpart H Cost Estimating Requirements, ${ }^{,}$U.S. EPA, January 1987.

OSWER Policy Directive \#94800-14, Combined NRC_EPA Siting Guidelines for Disposal of Commercial Mixed Low-Level Radioactive and Hazardous Waste," U.S. EPA, June 1987.

OSWER Policy Directive \#9950.1, "RCRA Ground-water Monitoring Technical Enforcement Guidance (TEGD), September 1986.

OSWER Policy Directive \#9500.00-60, "Interim Final RFI Guidance," Vol. 1-4, U.S. EPA, May 1989. 


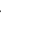




\section{SURFACE IMPOUNDMENTS}

This section presents the requirements for closure and post-closure care of surface impoundments containing hazardous and radioactive mixed wastes located at DOE facilities. A surface impoundment is defined in 40 CFR $\$ 260.10$ as a natural topographic depression, man-made excavation, or diked area formed primarily of earthen materials (although it may be lined with man-made materials), which is designed to hold an accumulation of liquid wastes or wastes containing free liquids, and which is not an injection well. Examples of surface impoundments are holding, storage, settling, and aeration pits, ponds, and lagoons. If a unit is self-supporting when not surrounded by earthen materials it is a tank, otherwise it is a surface impoundment.

\subsubsection{What are the Closure Requirements for Surface Impoumdments?}

Exhibit 4.2-1 provides an overview of the key closure requirements for surface impoundments and references to where in this section more detailed information is provided.

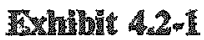

\section{Overview of Afplicable Statutory and Requlatory Remutrements}

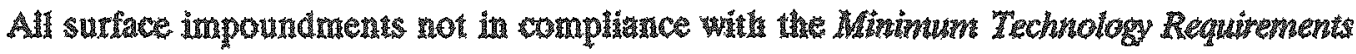
(MTRs) must retrofit or cease receipt of hazardous wastes after 11/8/88. Some surface impound ments nof meetng MTRs may be eligibie to delay closure and receive ony nonhazardous wastes.

Section 4.2.1.1

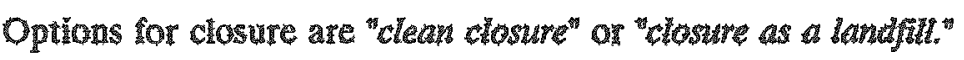

Sections $4.2 .2-4.2 .4$

Closure as a landful must also include 30 years of postmclosure core.

Section 4.2.4.4

Contingent tandfill closure and post-closure plans are regluired for any permitted surface impoundment not designed in accordance with the niner design standards.

Section 4.23 .2

Units clean clased under previous interim status requirements must submit an "equivatency denonstration" denonstrating hat closure sahishes Part 264 standards. If clean closure cannot be demonstrated, a post-ctosure pewir must be obtaimed. 


\subsubsection{Statutory Requirememts}

The Hazardous and Solid Waste Amendments (HSWA) of 1984 contained several changes to the original Act which affect the operation and closure of surface impoundments. Perhaps most important was the requirement that all surface impoundments that were in existence on November 8,1984 , and qualified to operate under interim status ${ }^{23}$, must either:

- Retrofit to meet the minimum technological requirements (MTRs) for surface impoundments; or

- Obtain a variance from these requirements; or

- Stop receiving, treating, and disposing of hazardous wastes by November 8,1988 (see following section on delayed closure of certain surface impoundments).

The MTRs for surface impoundments are as follows:

- Installation of a double liner system to minimize the potential for soil and ground water contamination;

- Leachate collection system (between the liners); and

- Part 264 ground-water monitoring.

The application deadline for exemptions to the retrofit requirements for interim status facilities has passed (the deadline was November 8,1986 ), as has the deadline for meeting the requirements to retrofit (November 8, 1988). Therefore, any surface impoundment (interim status or permitted) currently not in compliance with the minimum technological requirements and for which a variance has not been obtained, must stop receiving hazardous wastes (HSWA Section 3005(j)).

Variances from MTRs may be granted if it can be demonstrated that alternative design and operating practices, together with location characteristics, will prevent the migration of any hazardous constituents into the groundwater or surface water at least as effectively as such liners and leachate collection systems (HSWA Section 3004(0)). While exemptions were also granted for interim status impoundments, the application deadlines for these exemptions have already passed.

Guidance on MTRs and their requirements can be found in EPA's "Minimum Technology Guidance on Double Liner Systems for Landfills and Surface Impoundments: Design, Construction, and Operation," May 24, 1985, EPA/SW-870, "Lining of Waste Impoundment and Disposal Facilities," and EPA/530-SW-86-017, "Interim Status Surfoce Impoundments Retrofitting Variances," July 8, 1986.

23 This requirement includes facilities that: (1) qualified for interim status in November 8,1984 and are either still operating under interim status or are now operating under a RCRA Part B permit; and (2) were in existence on November 19, 1980. 


\subsubsection{Reguldatory Requirements}

The technical requirements pertaining to surface impoundments are found in 40 CFR Parts 264 and 265 , Subpart $\mathrm{K}, \$ 264.228$ and 265.228 , respectively. These requirements are in addition to the procedural requirements found in Subpart $G$, which are discussed in Chapter 3 of this manual. Exhibit 4.2-2 outlines the closure options for surface impoundments.

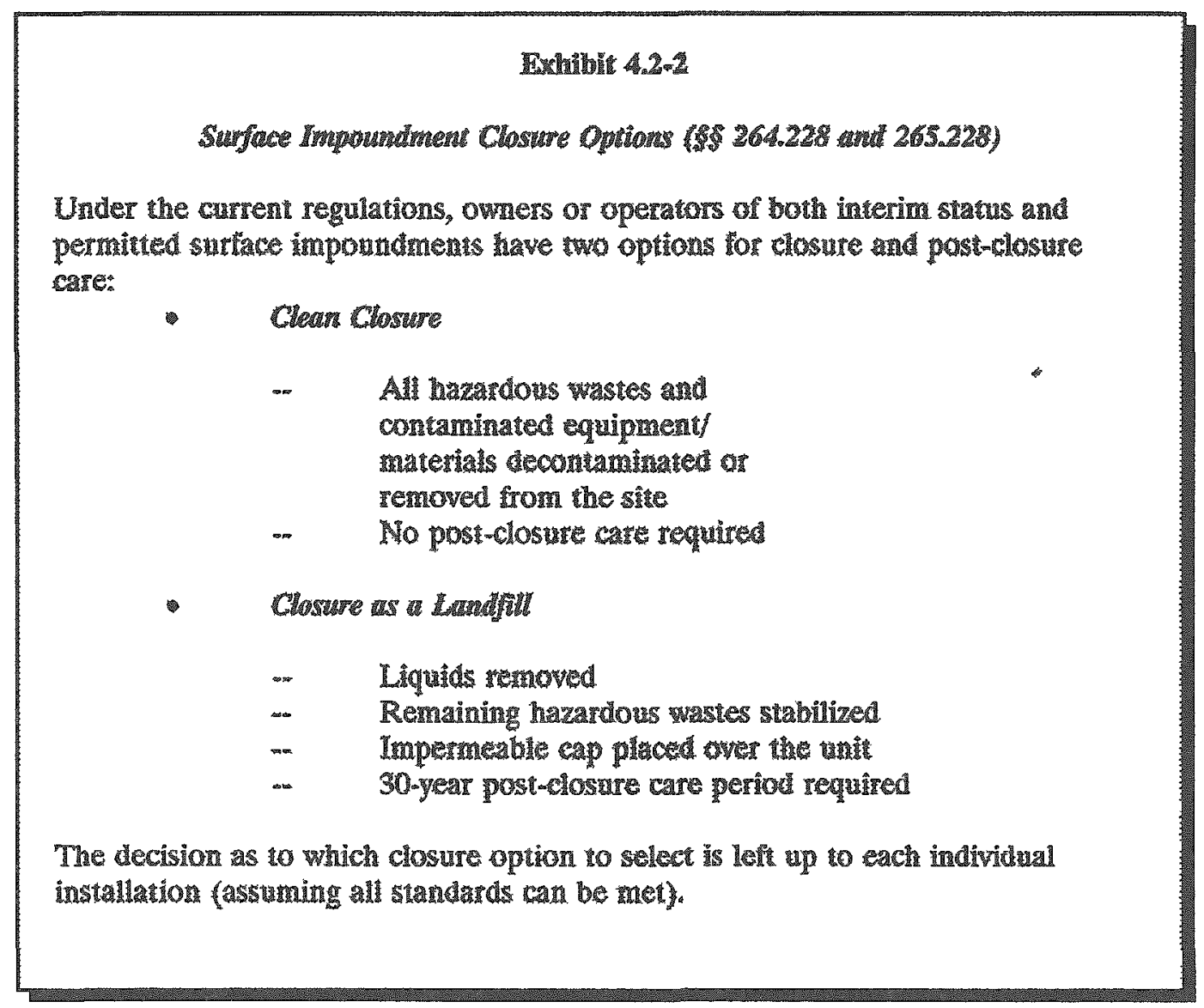

When the regulations for permitted units were first issued, they were more stringent than the interim status technical requirements. The regulations required owners or operators of permitted units to monitor ground water for all hazardous constituents listed in Appendix VIII of 40 CFR Part 261 which may have been generated, used, stored, or disposed at the site. In contrast, interim status units were only required to monitor for those hazardous wastes listed in Appendix VII of 40 CFR Part 261, a considerably smaller list. On March 19, 1987, EPA published a final regulation amending the interim status requirements for closure of hazardous waste surface impoundments (52 FR 8704) to conform to those requirements already in existence for permitted surface impoundments (40 CFR \$264.228). Both interim status and permitted facilities are now required to sample for Appendix VIII constituents î demonstrate that they have been removed (40 CFR 270.1(c)). 
Clasure Triggers for Surface Impoundments. As discussed above, HSWA requires all surface impoundments in existence on November 8,1984 , and qualified to operate under interim status, to retrofit to meet the MTRs by November 8,1988 , obtain a variance from these requirements, or stop receiving, treating, and disposing of hazardous wastes (HSWA Section 3005(j)). In addition, all units must comply with the RCRA Subpart G closure standards, which trigger the closure requirements 30 days after final receipt of hazardous waste or no later than one year after the date on which the unit received the most recent volume of hazardous waste, if the unit is likely to receive additional hazardous waste (40 CFR $\$ \$ 264.112(d)(2)$ and $265.112(d)(2)$ ). However, closure may not begin until the closure plan has been approved. Owners or operators of surface impoundments not meeting MTRs must either have their closure plan approved and begin closure, or discontinue receiving hazardous waste and begin receiving non-hazardous waste providing the surface impoundment meets the criteria for delayed closure discussed below.

Dellayed Closure. EPA recently issued regulations (40 CFR \$264.113) that allow surface impoundments to delay closure following final receipt of hazardous waste in order to receive nonhazardous waste (54 FR 33376). Owners and operators of surface impoundments that were forced to cease receipt of hazardous waste on November 8,1988 , because they did not meet the MTR liner and leachate collection system provisions, may also delay closure of these units under this rule. To be eligible to delay closure under these new requirements, an owner or operator of such a surface impoundment must do the following:

- Make several demonstrations and update facility plans as necessary to reflect changes due to the receipt of non-hazardous waste;

- Submit a contingent corrective measures plan (to expedite corrective action in the event of a release of hazardous constituents); and

- Submit and implement a plan for removing all hazarcous liquids and all sludges without impairing the integrity of the liner(s), if any are present.

The demonstrations, plan updates, and the contingent corrective action measures plan become a part of the surface impoundment's operating permit, and the unit must continue to operate in compliance with RCRA Subtitle C requirements.

Equivelency Demeonstrations. Any interim status surface impoundment that received wastes after July 26, 1982, and clean closed under Part 265 prior to March 19, 1987, must submit an "equivalency demonstration" showing that the closure satisfies all the requirements specified for permitted facilities in Part 264, even if the facility was otherwise subject to the interim status requirements. ${ }^{24}$ If clean closure camnot be demonstrated, then a post-closure permit must be obtained for the unit. Information on how to perform an equivalency demonstration is found in Section 4.2.3.4. EPA guidance on equivalency

24 EPA requires the equivalency demonstration for facilities closed prior to March 19, 1987, because after that date the requirements for interim status facilities were made identical to those for permitted facilities. Section 3005(i) of HSWA requires all surface impoundments that received wastes after July 26, 1982 , to comply with the ground-water monitoring, unsaturated zone monitoring, and corrective action requirements applicable to new units. 
demonstrations is found in OSWER Policy Directive $9476.00-18$, "Guidance on Demonstrating Equivalence of Part 265 Clean Closure with Part 264 Requirements," May 12, 1989 (included as Appendix G).

\subsubsection{Selecting Surfece Impoundment Clasure Options}

It is up to the individual facility operator to decide which closure option to implement. Clean closure is generally the preferred option because it eliminates the need for post-closure care; however, there are cases in which clean closure either may be technically or economically infeasible or impractical. Some factors which should be considered when selecting a closure option are listed in Exhibit 4.2-3.

In general, clean closure is most appropriate at relatively small impoundments where contaminant migration has been found to be minimal. Clean closure is also a good option when:

- The waste in the unit may be removed easily and treated for final disposal at a relatively low cost;

- The waste is generating gases that cannot be economically controlled;

- The foundation of the surface impoundment is in poor condition and requires costly repair; or

- Liners have been damaged beyond repair, yet extensive migration of leachate has not occurred.

Surface impoundments with ground water contamination remaining at closure are not allowed to clean close. To the extent that the ground water can be remediated to acceptable levels during the closure period, it may be possible to certify clean closure. However, if contamination has been detected in the unit's Subpart F ground-water monitoring system, the unit is subject to corrective action under $40 \mathrm{CFR}$ $\$ 264.100$. In that case, closure and corrective action activities must be coordinated. If the unit has interim status, it will be necessary to fully characterize the nature and extent of any contamination in the Part $B$ permit application under 40 CFR $\$ 270.14$ (c). Clean closure is also not usually an option at large surface impoundments, due to the sheer volume of material to be removed, and units in which the physical and/or chemical characteristics of the waste preclude or limit treatment or stabilization. Because hazardous wastes excavated during clean closures are subject to the LDRs, the cost of treatment to BDAT may be an importani consideration when selecting clean closure verses landfill closure. 


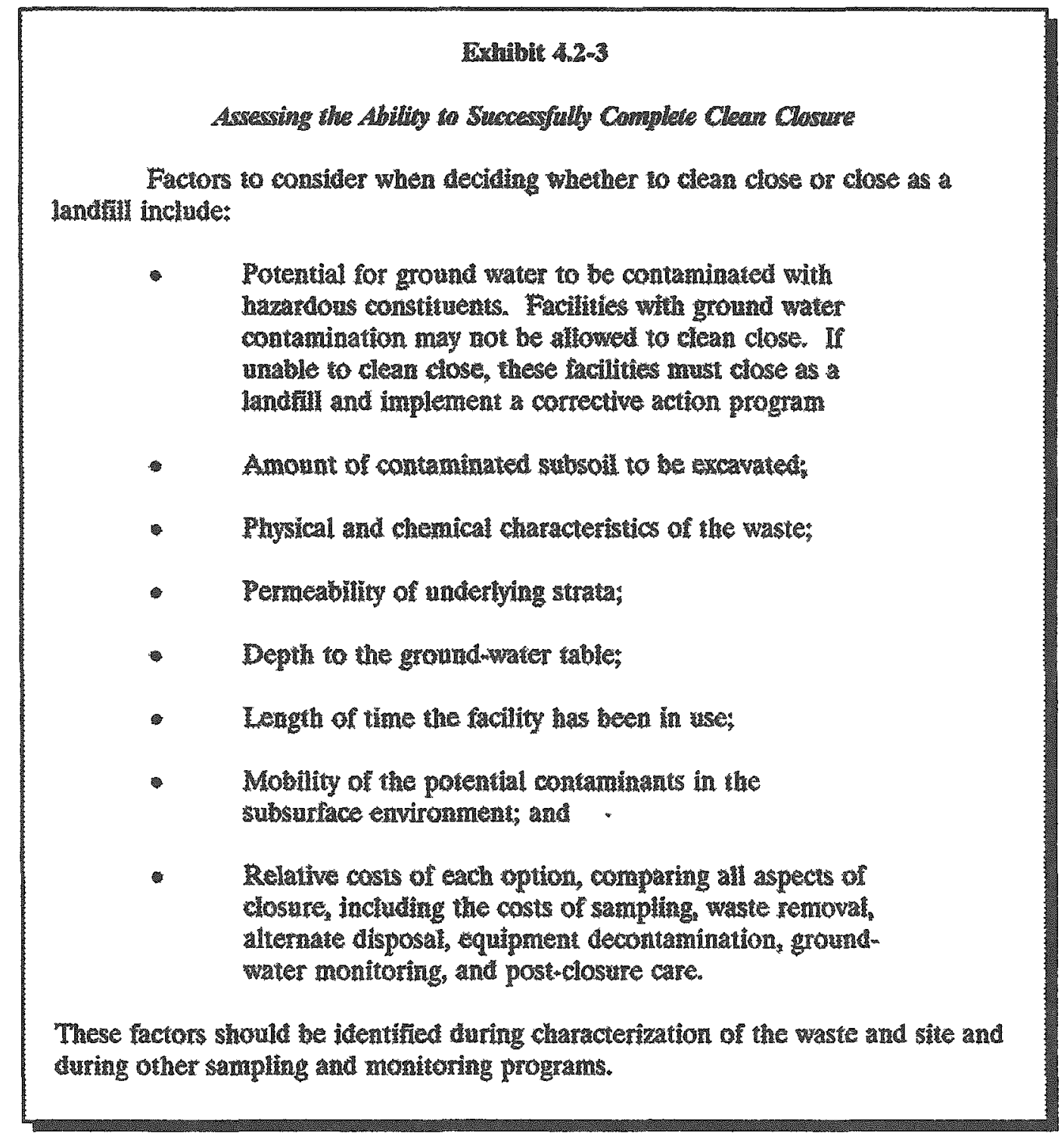

The following section outlines the requirements and additional guidance on clean closure of surface impoundments. Section 4.2 .4 outlines the requirements and guidance pertaining to landfill closure of surface impoundments.

\subsubsection{Clesure Closubre of Surfoce Impound meners}

The goal of clean closure is to remove or decontaminate all materials on-site that could potentially lead to future contamination. The technical requirements for clean closure are found in 40 CFR \$\$264.228(a)(1) and 265.228(a)(1). Under these requirements, all waste residues, containment system components, liners, subsoils, contaminated equipment, and structures must be decontaminated or removed from 
the site. These components must then be managed as hazardous waste unless specifically exempted under $40 \mathrm{CFR} \$ 261.3$ (i.e., if they do not exhibit hazardous waste characteristics or they have been delisted).

The following is an overview of the required activities for owners or operators of surface impoundments who plan to clean close their unit(s):

- Prepare closure plan (Section 4.2.3.1);

- Prepare contingent closure plan, if appropriate (Section 4.2.3.2);

- Conduct closure (i.e., remove or decontaminate all wastes, equipment, etc.) (Section 4.2.3.3); and

- Demonstrate clean closure (Section 4.2.3.4).

The following sections provide guidance on how to properly perform each of these activities.

\subsubsection{Prepuring Surface Impoundment Clean Closure Plans}

A written closure plan is required for all closures, including clean closures. Exhibit 4.2-4 summarizes the information requirements for a clean closure plan.

Establishment of Contumination Cleanup Targets. The closure plan must include a listing of the exposure limits for all hazardous constituents which may have been generated, used, stored, or disposed at the unit. These constituents include, but are not limited to, those listed in 40 CFR Part 261, Appendix VII. The exposure limits will be used as standards at the time of closure for assessing whether or not removal and decontamination activities are complete. The exposure limits chosen in the plan for the hazardous component of a mixed waste should be an EPA recommended limit if one exists. Exhibit 4.2-5 provides sources of information on EPA's recommended exposure limits for hazardous constituents: 


\section{Facility Conditions}

Inventory and Decontamination

Clean Closure Demonstration

Ground-Water Monitoring

Securioity Systems
- Facility location and size;

- Topographic map;

- List of other hazardous waste management units and wastes handled in each;

- Hydrogeological information;

- Surface impoundment description (volume, size, type of liner system, etc.);

- Description of past releases and corrective measures taken;

- References to other environmental permits; and

- Anticipated waivers or exemptions.

- Estimates of inventory to be removed;

- Procedures for handling removed inventory;

- Procedures for decontamination or disposal of equipment, rinsewater, contaimment systems and soil; and

- Major radionuclides and their concentrations.

- Listing of exposure limits for Appendix VIII constituents;

- Background levels at the site; and

- Description of the testing to determine if liner, equipment, etc. are hazardous.

- Procedures for monitoring analysis; and

- Number, location, and frequency of samples.

- General description. 
Exhibit 4.2-4 (Continued)

SURFACE IMPOUNDMENT CLEAN CLOSURE PLAN SAMPLE OUTLINE

Section Elements

Survey Plat

Closure Certification

Schedule of Closure
- Surveyed benchmarks.

- Activities to be conducted; and

- Documentation.

- Expected year of closure (only for interim status facilities without approved closure plans);

- Time required for waste treatment, removal, decontamination, and final closure; and

- Support for deadline extensions, if applicable.

Source: OSWER Policy Directive No. 9476.00-5, "RCRA Guidance Manual for Subpart G Closure and Post-Closure Care Standards and Subpart H Cost Estimating Requirements (Draft)". 


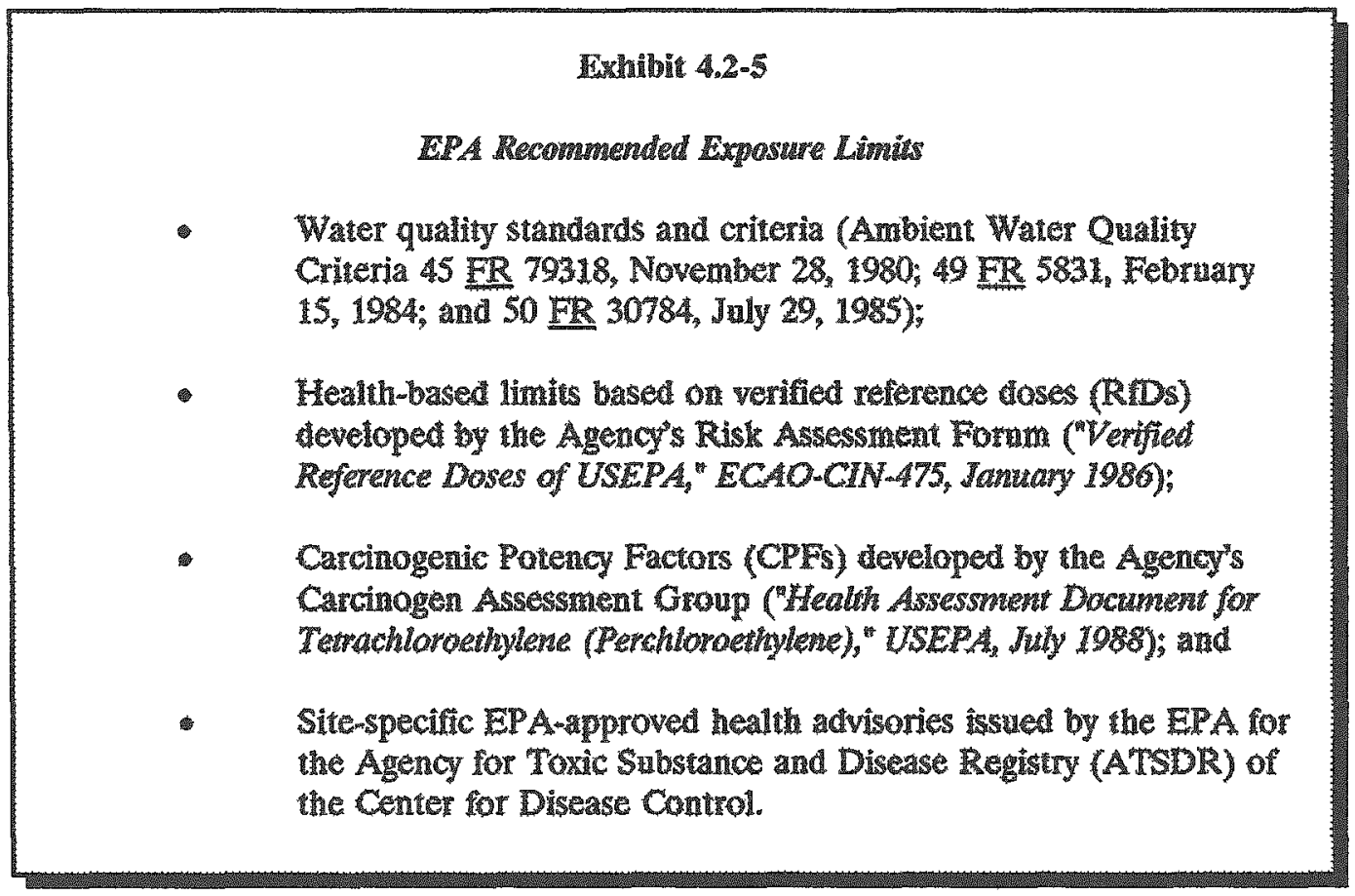

While the radioactive component of the waste is not subject to RCRA regulation, it may be appropriate to address these contaminants in the closure plan. The cleanup of radioactive materials is discussed later in this section. The application of chemical exposure limits and EPA risk assessment guidelines require the establishment of intake assumptions, such as those presented in Exhibit 4.2-6. Intake is the amount of substance taken into the body per unit body weight per unit time and is calculated separately for each environmental medium, i.e., air, ground-water, surface water, and soil. Intakes for each individual chemical exposure pathway are summed for each exposed population at risk, resulting in a total oral exposure, total inhalation exposure, etc. The intake assumptions presented in Exhibit 4.2-6 may be varied to incorporate site-specific conditions. The standard values presented assume 24-hour exposure over the duration of contamination and therefore do not take into account reduced human activity at the site. Additional guidance on intakes may be provided by the Exposure Assessment Group, Office of Research and Development, U.S. EPA, Washington D.C., 20460.

If no EPA recommended limits exist for the contaminants of concern in the impoundment, the owner or operator may wish to consider these additional options:

- Remove the constituent to background levels; or

- Submit toxicity data on the constituent using the procedures outlined in the Toxic Substance Control Act to show that contaminants do not pose a threat at the point of exposure; or

- Close the impoundment as a landfill. 
Exhibit 4.2.6

STANDARD INTAKE ASSUMPTIONS'-

Environmental Medium

Intake Assumption

Soil

0.1 g/day for $70 \mathrm{~kg}$ adult

$0.2 \mathrm{~g} / \mathrm{day}$ for $16 \mathrm{~kg}$ child

Ground-Water

2 liters/day for $70 \mathrm{~kg}$ adult

Surface Water

2 liters/day for $70 \mathrm{~kg}$ adult

Air

$20 \mathrm{~m}^{3}$ air/day for $70 \mathrm{~kg}$ adult

a) As an example of how to apply the standard intake assumption, if contaminant concentration is 3 mg/liter in drinking water:

( 3 mg/liter $\mathrm{x} 2$ liters/day water consumption) $\div 70 \mathrm{~kg}$ body weight $=0.086 \mathrm{mg} / \mathrm{kg} / \mathrm{day}$ intake

Source: OSWER Policy Directive \#9502-00-60, "RCRA Facility Investigation Guidance," May 1989. 
Rouliation Exposure Limits. Although not required by RCRA, DOE requires that external exposure to the radioactive component of mixed waste from all environmental medium, plants, and animals not exceed an effective dose equivalent of $25 \mathrm{mrem} / \mathrm{year}$ to any member of the public. The concentration of a radionuclide may be determined by either direct methods or by indirect methods such as scaling factors that relate the inferred concentration of one radionuclide to another that is measured, or radionuclide accountability. Radiation standards and concentration guides applicable to DOE operations are found in DOE 5480.11, Radiation Protection for Occupational Workers, December 21, 1988.

Wastes containing amounts of radionuclides below regulatory concern (BRC) may be disposed without regard to radioactivity content (DOE 5820.2A, Radioactive Waste Management, September 26, 1988). The NRC is developing a rule governing the disposal of radioactive waste determined to be below regulatory concern. It is expected that such a rule may establish a risk or dose value that would represent generic regulatory cut-off levels for radioactive wastes. If DOE does not adopt this rulemaking, this requirement will not be applicable.

Establishimg Backgroured Concentrations. The subsoil at the facility should be sampled and analyzed when the Part $B$ application is prepared and the results should be included in the closure plan. The results may later be used as target levels for demonstration of clean closure. Background levels must be established for ground-water, soil, and surface water (if appropriate), and must reflect the natural or existing local conditions unaffected by operations of the unit:

- Ground-Water Quality -- To establish background ground-water quality, monitoring wells must be placed upgradient from the unit as provided in 40 CFR Parts 264 and 265 , Subpart $F$. The wells should be located in an area unaffected by the closing unit and of comparable subsurface strata. The number of wells and samples to be collected is dependent upon the particular site. However, a minimum of one year of data (quarterly samples) must be collected. The use of clustered wells will help ensure that a complete vertical profile of ground-water quality is obtained.

- Soil Qualicy -- Soil should also be sampled in an area unaffected by operations at the impoundment to obtain accurate background levels. Sampling should be performed at depths comparable to the depth of soil directly below the surface impoundment.

- Surface Wrater Quality -- Background levels for surface waters need only be established if there is a potential for surface water contaminant migration. In those cases where it is needed, surface waters upgradient from the surface impoundment should be sampled. The sampling should also be located upstream from any surface-water run-off discharge points.

Owmers or operators of interim status surface impoundments that received waste after July 26 , 1982, and permitted surface impoundments, must comply with the permitted facility ground-water monitoring requirements ( 40 CFR $\$ \$ 264.90$ - 264.101) during the active life of the facility, including the closure and post-closure periods. Guidance on data collection requirements and evaluation procedures are found in OSWER Policy Directive 9950.1, "RCRA Ground-Water Monitoring Technical Enforcement Guidance Document (TEGD)," September 1986. 
If the impoundment contains mixed wastes, the monitoring program should also comply with the requirements found in DOE 5484.1. Environmental, Safety, and Health Protection Information Reporting Requirements, February 24, 1981, in addition to the Orders listed in Section 2.3. At a minimum, the migration of radionuclides and impoundment subsidence should be monitored.

\subsubsection{Contingent Closure and Post-Closuse Plares}

Contingent closure plans, which describe how the impoundment will be closed as a landfill if clean closure cannot be achieved, must be prepared for any permitted surface impoundment that was not designed in accordance with the liner design standards specified in 40 CFR \$264.221(a) or is not exempt from them in accordance with $40 \mathrm{CFR} \$ 264.221(\mathrm{~b}) .^{25}$ In addition, a post-closure plan describing 30 years of post-closure monitoring and maintenance activities is also required. Owners or operators of interim status facilities are also encouraged to prepare contingent closure and post-closure plans, especially if it appears that clean closure of the facility is not likely to be achieved. Contingent closure and postclosure plans may also be required if the EPA Regional Administrator determines that a surface impoundment not subject to the contingent plan requirement must be closed as a landfill. Surface impoundments not meeting the November 8, 1988, deadline for retrofiting must have already submitted a closure plan that included a contingent closure plan.

The following information should be included in contingent closure and post-closure plans:

- Final cover design: including engineering drawings, area covered, cover characteristics, installation procedures, and erosion control procedures;

- Ground-water monitoring: including information on well installation, types of analyses to be performed, and maintenance of equipment;

- Security systems: including a description of the existing system and any proposed changes for the post-closure period;

- Closure schedule: including a milestone chart showing cover installation, vegetation planting, and total time to complete closure; and

- Post-closure: including provisions for the kinds of monitoring and maintenance activities that will be expected during the post-closure care period.

Section 4.2.4 contains more information on closure and post-closure plans for landfill closure.

25 Under the liner design standards, storage impoundments are required to have a liner that allows seepage into, but not out of, the liner during the life of the facility (e.g., synthetic liner). In addition, the standards address the chemical characteristics of liners, liner strength and thickness, liner foundations, and liner lateral extent. 


\subsubsection{Implementing Cleven Closure of Surface Impoundments}

In order to properly clean close a surface impoundment, all wastes, waste residues, contaminated containment system components (e.g., liners), contaminated subsoils, ${ }^{26}$ and structures and equipment contaminated with waste and leachate must be either removed or decontaminated.

All removed materials (e.g., liquids, sludges, etc.) must be managed as hazardous waste unless the wastes have been delisted (specified in $40 \mathrm{CFR} \$ 261.3$ (d) and discussed in Section 2.1.2.4). In addition, if these materials are mixed wastes, they must be managed in accordance with DOE 5280.2A, Radioactive Waste Management, September 26,1988 . In addition, if the waste to be removed and disposed is prohibited from land disposal under the land disposal restrictions (LDRs), it must be treated by a method that meets the treatment standards of 40 CFR $\$ \$ 268.40$ to 268.44 .

Liquids Removal. All free liquids must be removed from the impoundment. In general, the liquids will be present in the upper layer of the impoundment above the waste solids and will have a relatively low suspended solids content. There are several options available for the removal of free liquids, including evaporation, underdrainage, and mechanical removal. The most common method is mechanical removal by pumping. Evaporation is not often used due to the long drying times required. In general, sludges with a solids content less than 8 to 10 percent are pumpable. In order to remove liquids with a solids content greater than 8 to 10 percent, either additional liquid must be added to lower the solids content or the sludge must be dewatered in place. The specific type of pump chosen for the operation is dependent on the physical and chemical characteristics of the waste.

Another common technique for liquids removal is evaporative drying with gravitational or vacuum assisted drainage or with progressive trenching. Other methods of liquids removal include filtration (using either a filter press or pressure filter), centrifuging, and thermal drying. Detailed guidance on dewatering and equipment selection and costs is provided in EPA/625/6-85/006, "Handbook on Remedial Actions at Waste Disposal Sites," October 1985.

Sludge Removal. Sludge removal should begin before removal of the liner to ensure that the liner's integrity is maintained and to minimize leakage of waste or leachate. The sludge may either be removed in its wet form or air dried first and then removed. The dry method requires that the sediment be air dried and then excavated. Although this method requires more time, it mimimizes the amount of waste that ultimately requires disposal. The drying process may be shortened by plowing, disking, or using a similar method.

The most common method of excavating the wastes is by mechanical means. Excavation of the wastes can be accomplished using a crane (with attachments such as a clam shell bucket), backhoe, or bulldozer. A crane or backhoe should be used to remove plastic or semisolid sediments and a bulldozer can be used to break down any solidified materials prior to excavation. To prevent the generation of dust during waste removal, water sprays should be used. The selection of equipment is again dependent on the

\footnotetext{
${ }^{26}$ EPA interprets "soils" to include both unsaturated soils and soils containing ground water. For this reason, a clean closure must include consideration of potential ground-water contamination under both Parts 264 and 265 (53 FR 8705 and 53 FR 9944).
} 
waste materials; however, detailed guidance on the selection of equipment for sludge removal is provided in Section 7.1 of EPA/625/6-85/006, "Handbook on Remedial Actions at Waste Disposal Sites, "October 1985.

The sludge must be disposed in a manner consistent with RCRA requirements. Contaminated sludges are subject to the land disposal restrictions program discussed in Section 2.1.4.

Liner Removal. The impoundment liner should be removed following waste removal and before removal of any subsoils to minimize the potential for additional contamination of the subsoil. Normal excavation methods can be used to remove liners made of clay and soil. However, concrete or gunnite liners should first be broken up and then removed. Flexible membrane liners should be removed in small subsections, in a similar manner in which they were installed. Detailed guidance on liner removal is provided in EPA/SW-873, "Closure of Hazardous Waste Surface Impoundments," 1982.

Soils Removal. Following removal of the liner, soils underlying the surface impoundment must be tested to determine the extent of contamination. Any soils which have been determined to contain contaminants in excess of the exposure limits specified in the closure plan must be removed. The soil should be removed in layers and sampling conducted following removal of each layer. This procedure will help minimize the amount of soil removed. Excavation should be completed as quickly as possible to reduce the probability of rain transporting contaminants through the unsaturated zone.

Equipment Decontamination. The regulations require owners or operators of surface impoundments to decontaminate all equipment, tools, supplies, etc., involved in operating, maintaining, and closing the unit. Guidance on procedures for equipment decontamination are provided in EPA/600/2-85/028, "Guide for Decontaminating Buildings, Strucures, and Equipment at Superfund Sites," 1985.

\subsubsection{Demonstrating Clean Closure (AO CFR 270.1)}

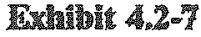 \\ How Clewn is Clewa?}

To demonstrate clean closure, the soil ard ground water surrounding the impoundmen must be tested to document that the contaminants left in the subsoils will not impace the ground water, surlace water, or the amosphere in excess of the exposure limits specified in the facility's approved closure plan. For the purposes of making a clean closure demonstration, 站e potential point of exposure atach whe specified exposure limits must be met is directy at or within the unit boundary for all

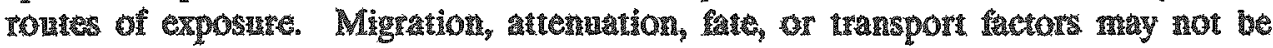
considered.

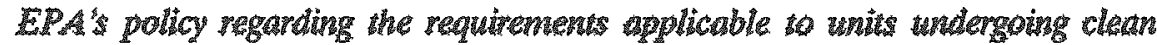
closure is most clearly expressed in 52 12R 8704 and 53 FR 0944 \%. 
Ground-Water Pathway. To demonstrate clean closure with respect to the ground-water pathway, the following actions must be taken:

- Remove contaminated soil and saturated subsoils to demonstrate that constituent levels in ground water do not exceed EPA-established chronic health levels (based on Reference Dose (RID) or Carcinogenic Slope Factor (CSF) values); and

- Show that residual contaminant levels remaining in the soil will not contribute to any future contamination of ground water by showing that levels of constituents found in leachate are not above the EPAestablished exposure levels. Levels of constituents in leachate may be estimated based on known characteristics of the waste constituents or determined by the results of actual soil leaching tests.

Direct Contact Pathwary. To demonstrate clean closure with respect to the direct contact pathway, contaminant levels in soils must be below levels established by EPA as acceptable for ingestion or dermal contact. Soil core samples must be collected at random sampling points over the entire area of the unit. Locations for the samples may be determined using two-dimensional random sampling. Total waste constituent levels in soil should be used for this analysis.

Air Exposures. The analysis of potential air exposures should assess contaminants migrating from the soils into the atmosphere. The demonstration should include:

- Emission calculations;

- Available monitoring data; and

- Safe inhalation levels based on EPA-established exposure levels.

Surface Water Expostures. The potential surface water exposure analysis should compare EPAestablished water quality standards and criteria (45 FR 79318, November 28,1980 ) with the levels of constituents that may leach from the residual contaminated soil. The surface water exposure analysis should also consider existing surface water contaminant concentrations.

Clean Closure Equivalency Demonstrations. A special requirement applies to all surface impoundments that received wastes after July 26, 1982, and certified clean closure under the Part 265 requirements prior to March 19, 1987. These units must submit an equivalency demonstration, which demonstrates that the closure satisfies all the requirements specified for permitted facilities in Part 264, even if the facility has operated under, and is otherwise subject to, the Part 265 interim status requirements. $40 \mathrm{CFR}$ Sections $270.1(\mathrm{c})(5)$ and (6) outline the procedures for determining if the closure met Part 264 standards. Clean closure may be demonstrated in one of the following ways:

- If the owner or operator submitted a Part B application for a post-closure permit, he can request a determination based upon the information contained in the application; or 
- If the owner or operator has not submitted a Part B application for a post-closure permit, he may petition the Regional Administrator for a determination of equivalency. The petition must include all the data necessary to demonstrate that closure by the removal or decontamination standards in $\$ 264.228$ were met or that the unit closed under State requirements that are at least as stringent as $\$ 264.228$.

The owner or operator will be notified within 90 days of the submission as to whether or not the demonstration has been approved (40 CFR \$270.1). If upon review of the equivalency demonstration, EPA determines that the closure does not meet the Part 264 standards, a post-closure permit application addressing all applicable Part 264 requirements (including ground-water monitoring, corrective action, and post-closure care) must be submitted (see section 4.2 .4 on landfill closure of surface impoundments for guidance on post-closure permits and procedures). Additional information in support of the equivalency demonstration may be submitted to the Regional Administrator along with a request that the demonstration be reevaluated. This request must be submitted within 30 days of receipt of a notice of denial by the Regional Administrator. A final determination will be provided within 60 days of a second submittal.

EPA guidance on equivalency demonstrations is provided in OSWER Policy Directive \#9476.00.18, "Guidance on Demonstrating Equivalence of Part 265 Clean Closure With Part 264 Requirements," Moy 12, 1989 (see Appendix $G$ ). If clean closure cannot be demonstrated, the unit must be closed as a landfill and a post-closure permit must be obtained for the unit (see Section 4.2.4).

\subsubsection{Landfull Closure of Surfoce Impoundments}

The requirements for landfill closure of surface impoundments are found in $40 \mathrm{CFR}$ $\$ \$ 264.228(a)(2),(b) ; 265.228(a)(2),(b)$; and 265.310 (requirements for closure of interim status hazardous waste landfills). The EPA has established a combination of design and operational requirements with the purpose of minimizing leachate generation and the potential migration of contaminants into the environment. Under these requirements, all liquid wastes must be either removed or solidified and the remaining wastes stabilized. The regulations specify that a final cover must be installed that meets the following specifications:

- Provide long-term minimization of the migration of liquids through the closed impoundment;

- Function with minimum maintenance;

- Promote drainage and minimize erosion or abrasion of the final cover;

- Accommodate settling and subsidence so that the cover's integrity is maintained; and

- Have a permeability less than or equal to the permeability of any bottom liner system or natural subsoils present. 
In addition, closure of a surface impoundment as a landfill requires 30 years of post-closure care during which the unit is monitored and maintained to ensure that no additional contamination occurs.

Following is an overview of the required activities for owners or operators of surface impoundments who plan to close their unit(s) as a landfill:

- Prepare closure plan (Section 4.2.4.1);

- Prepare post-closure plan (Section 4.2.4.2);

- Conduct closure (i.e., eliminate free liquids, stabilize wastes, and install a final cover) (Section 4.2.4.3); and

- Conduct post-closure care (Section 4.2.4.4).

\subsubsection{Propuring Landill Closure Plans}

A written closure plan is required for closure, as described in Chapter 3 of this manual. An outline of a sample closure plan for a surface impoundment closing as a landfill is presented in Exhibit 4.2-8. As indicated in the exhibit, the closure plan should include detailed information on how free liquids will be removed or solidified and how the remaining wastes will be stabilized. Analysis should also be provided in the plan that demonstrates that the selected stabilization method will provide adequate support for the final cover. Representative samples of the waste should be stabilized using the planned method and analyzed to determine its bearing strength (the strength of the stabilized waste can be determined using ASTM method D21166-66, the U.S. Arrwy's method specified in "Engineering and Design Laboratory Soils Testing, Appendix VII," (EM 1110-2-1906), or an equivalent method).

Additional information related to the design of the final cover should be discussed in the closure plan:

- If the EPA's recommended cover design (see Section 4.2.4.3) is not used, data demonstrating that the proposed design provides equivalent, or more, protection against infiltration than the EPA design must be provided. EPA suggests that the HELP model be used for this demonstration ("User's Guide for the Hydrologic Evaluation of Landfill Performance (HELP) Model," EPA 530 SW 84009);

- Data demonstrating that the proposed design will not result in erosion of the cover. Guidance on appropriate slopes is found in EPA's "Technical Guidance Document: Final Covers on Hazardous Waste Landfills and Surface Impoundments, "July 1989. A description of the types of material to be used in the drainage layer of the final cover and its permeability, the potential for clogging, and the direction of drainage should also be included; 
LANDFILL CLOSURE PLAN SAMPLE OUTLINE FOR SURFACE IMPOUNDMENTS

Section

Elements

\section{Facility Conditions}

Removal of Inventory

Facility Decomeamination

Waste Stabilization

Fingl Cover Design
- Facility description;

- Surface impoundment description;

- Hydrogeological conditions;

- References to other environmental permits; and

- Anticipated waivers or exemptions.

- Estimation of maximum waste volume and

- Detailed information on how free liquids will be removed/solidified.

- Procedures for handling, decontamination and/or disposal of other removed inventory (e.g., equipment and contaminated soils).

- Detailed plans describing how the wastes will be treated/stabilized; and

- Results from analyses demonstrating that stabilized wastes provide sufficient permanent support for the cover and other loadings.

- Engineering drawings;

- Installation procedures;

- If a design other than that suggested by EPA is used, include engineering calculations demonstrating that cover will provide long-term minimization of the migration of liquids through the closed impoundment and that infiltration is equivalent to or less than cover design provided by EPA; and 
LANDFILL CLOSURE PLAN SAMPLE OUTLINE FOR SURFACE IMPOUNDMENTS

Section

Elements

Final Cover Design (Contimued)

Groumd-Water Monitoring

Security Systems

Survey PIR

Closure Certification

Schedule of Closure
- Demonstration that cover will function effectively with minimum maintenance.

- Procedures for monitoring analysis; and

- Number, location, and frequency of samples.

- General description.

- Surveyed benchmarks.

- Activities to be conducted and Documentation.

- Expected year of closure (only for interim status facilities without approved closure plans);

- Time required for waste treatment, removal, decontamination, and final closure; and

- Support for deadline extensions, if applicable.

Source: OSWER Policy Directive No. 9476.00-5, "RCRA Guidance Manual for Subpart G Closure and Post-Closure Care Standards and Subpart $\mathrm{H}$ Cost Estimating Requirements (Draft)". 
- Results from consolidation tests performed on soil samples. In addition, data on potential settlement due to consolidation of the liner, foundation soils, compression of the impounded waste material, and biological oxidation of organics (See "Technical Screening Guide for CERCLA Soils and Sludges," EPA 540/2-08-004, September 1988);

- Documentation showing that the permeability of the final cover is less than or equal to the permeability of the bottom liner system; and

- Information on the effects of extreme temperatures on the proposed cover.

\subsubsection{Preporingy Post-Closure Plars}

Owners or operators of surface impoundments that are closed as landfills are required to conduct post-closure care for 30 years after closure and must comply with all post-closure procedural requirements contained in 40 CFR $\$ \$ 264.117$ through 264.120 for permitted facilities and 40 CFR $\$ \$ 265.117$ through 265.120 for interim status facilities, including maintenance and monitoring throughout the post-closure care period. The EPA Regional Administrator has the authority to extend or reduce the period for postclosure care on a case-by-case basis.

Provisions for the kinds of monitoring and maintenance activities that reasonably can be expected during the post-closure care period must be specified in a post-closure plan, which must be included in the Part B application. The plan must include a description of all planned monitoring activities and the frequency, including the following information (40 CFR $\$ 264.118(\mathrm{~b})$ )):

- Frequency and scope of inspections;

- Procedures for making repairs to the cover;

- Procedure for leachate collection, removal, and treatment;

- Frequency of sampling and monitoring;

- Maintenance of monitoring systems; and

- Name, address, and phone number of contact person during the postclosure period.

Further guidance is provided in EPA/SW-867, "Evaluating Cover Systems for Solid and Hazardous Waste." 


\subsubsection{Implementing Landifill Closure of Surface Impoundments}

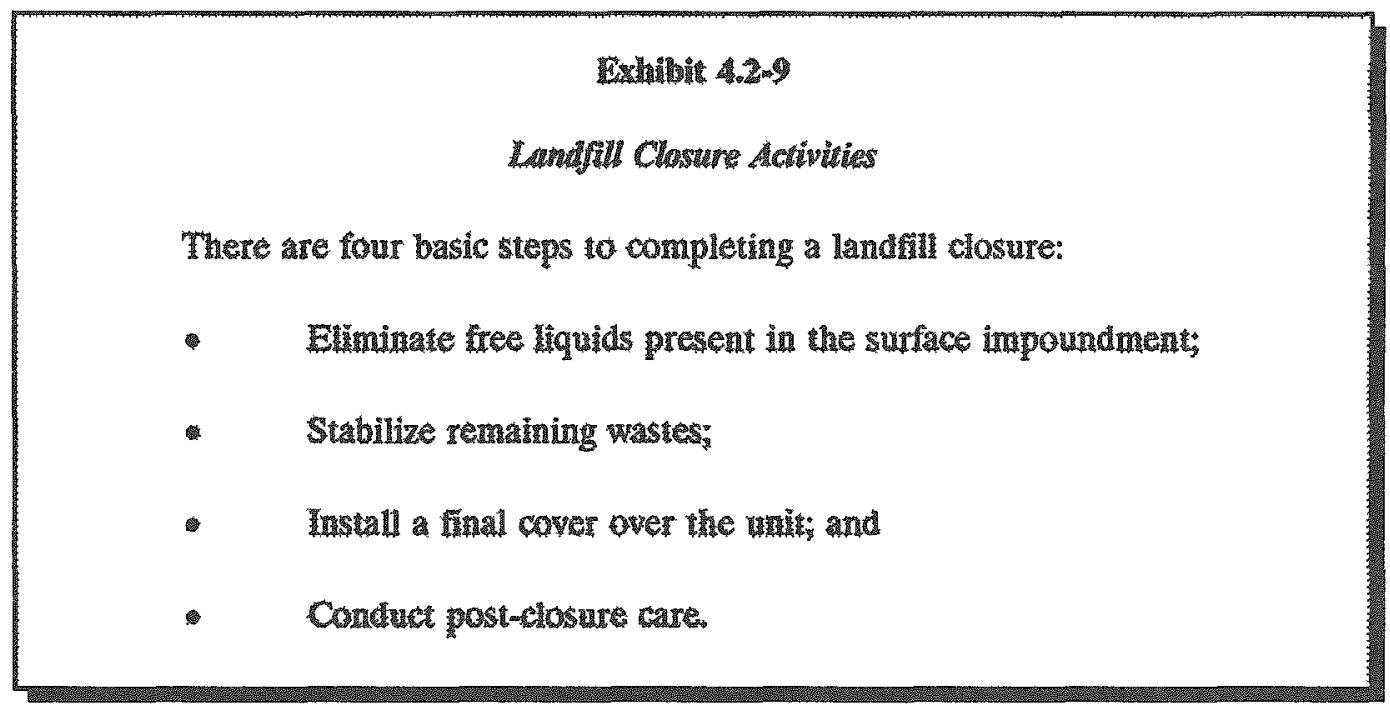

Elimination of Free Liquids. When closing a surface impoundment as a landfill, first eliminate all free liquids from the unit by either removing or solidifying them in order to minimize future leachate migration. Liquids removal is important for landfill closure because free liquids will not adequately support a final cover. Methods for liquids removal are discussed in Section 4.2.3.3. Additional liquids removal methods include mechanical dewatering using a filter press and thermal drying. The advantage of thermal drying over dewatering is that no filtrate is produced; however, the process is energy-intensive and problems related to air emissions may result. Further guidance is provided in "Guidelines for Dewatering/Densifying Confined Dredged Material," U.S. Watenwoys Experiment Station Technical Report DS$78-11$

In order to improve the stability of the radioactive component of the mixed waste, DOE requires the liquid wastes to be converted into a form that contains as little freestanding and noncorrosive liquid as is reasonably achievable (DOE 5820.2A, Radionctive Waste Management, September 26, 1988). Specifically, liquids cannot exceed 1 percent of the waste volume when the waste is in a disposal container, or 0.5 percent of the volume of the waste processed to a stable form.

Stabilization of Wastes. All remaining wastes and waste residues in the impoundment must be stabilized. The stabilized material must be strong enough to support the final cover and must be able to immobilize contaminants. Problems may occur if the final cover settles differentially over the unit, creating channels through which liquids can enter the unit. This may eventually lead to leaching of the waste constituents into the ground water. The stabilization method chosen should be determined by testing. Testing is needed because the effectiveness of any one method is dependent on several factors, including the thickness of the waste residues; anticipated load; climate; leachability of waste constituents; site geology; and final cover design. Stabilization methods include the following:

- Portland-cerment bosed process -- The most common method used for stabilization is the Portland-cement based process. Portland cement is 
composed of a combination of calcium silicates, calcium aluminates, and calcium ferro-aluminates, which hydrate and harden when mixed with water. The resulting material incorporates the waste into a solidified mass. Cement is added to the waste in a ratio ranging from 0.2:1 to 1:1. Portland cement is effective in solidifying most organic and inorganic solids; however, it has not been found to be effective for binding sludges containing more than 20 percent organic liquids. Although it is less costly to perform stabilization in the unit itself, the process is usually more effective when the wastes are removed to allow for more thorough mixing.

Portland cement treatment has been estimated to result in up to a 100 percent increase in volume, depending on the initial solids content of the waste material. Therefore, the additional volume required for containment should be examined when considering this process.

- Diological preareutment -- Units containing a large portion of organic materials may require biological pretreatment (e.g., land treatment and composting) to reduce the organic content of the wastes prior to stabilization. Biological pretreatment; however, may add an additional few weeks, or even months, to the closure process.

- Pozzolonic materials -- Portland cement is often used in combination with a pozzolonic material, such as cement kiln flyash or flyash from fossil fuel power plants. Other materials such as clay, gypsum, sodium silicate, or calcium chloride may be added to control the setting reaction or to produce a residual with special characteristics. The addition of bentonite clay or the use of excess flyash can produce a soil-like residual which can easily be handled with conventional earth moving equipment.

- Other methods -- Other stabilization techniques include thermoplastic methods, organic polymer, surface encapsulation, and vitrification.

Guidance on stabilization technologies is found in EPA's "Guide to the Disposal of Chemically Stabilized and Solidified Waste," SW-872 (September 1982).

Final Cover. The surface impoundment must be covered with a final cover to provide long term minimization of precipitation and run-off into the closed impoundment (the standards for final covers are discussed in detail in Section 4.1.2.2). Before construction of the cover can begin, the wastes must be tested to verify that solidification and compaction are complete. If the wastes are likely to emit gases, it is advisable to install a gas venting system in the waste layer at this time to prevent future build up of pressure under the final cover. In addition, a foundation of baclfill should be placed on the waste surface before construction to provide support and a good working surface.

The cover requirements are performance standards which allow some flexibility in design. Final covers for both interim status and permitted units must be designed with a permeability equal to or less than the permeability of the bottom liner system or natural subsoils. This is to prevent the "bathtub 
effect," i.e., liquid buildup and eventual overflow due to precipitation that enters the unit through the cover but cannot escape through the bottom liner. In addition, covers which minimize erosion or abrasion and can accommodate settling and subsidence are required (40 CFR \$\$264.228(a)(2) and 265.228(a)(2)). Exhibit 4.2-10 outlines EPA's recommended final cover design for surface impoundments closed as landfills.

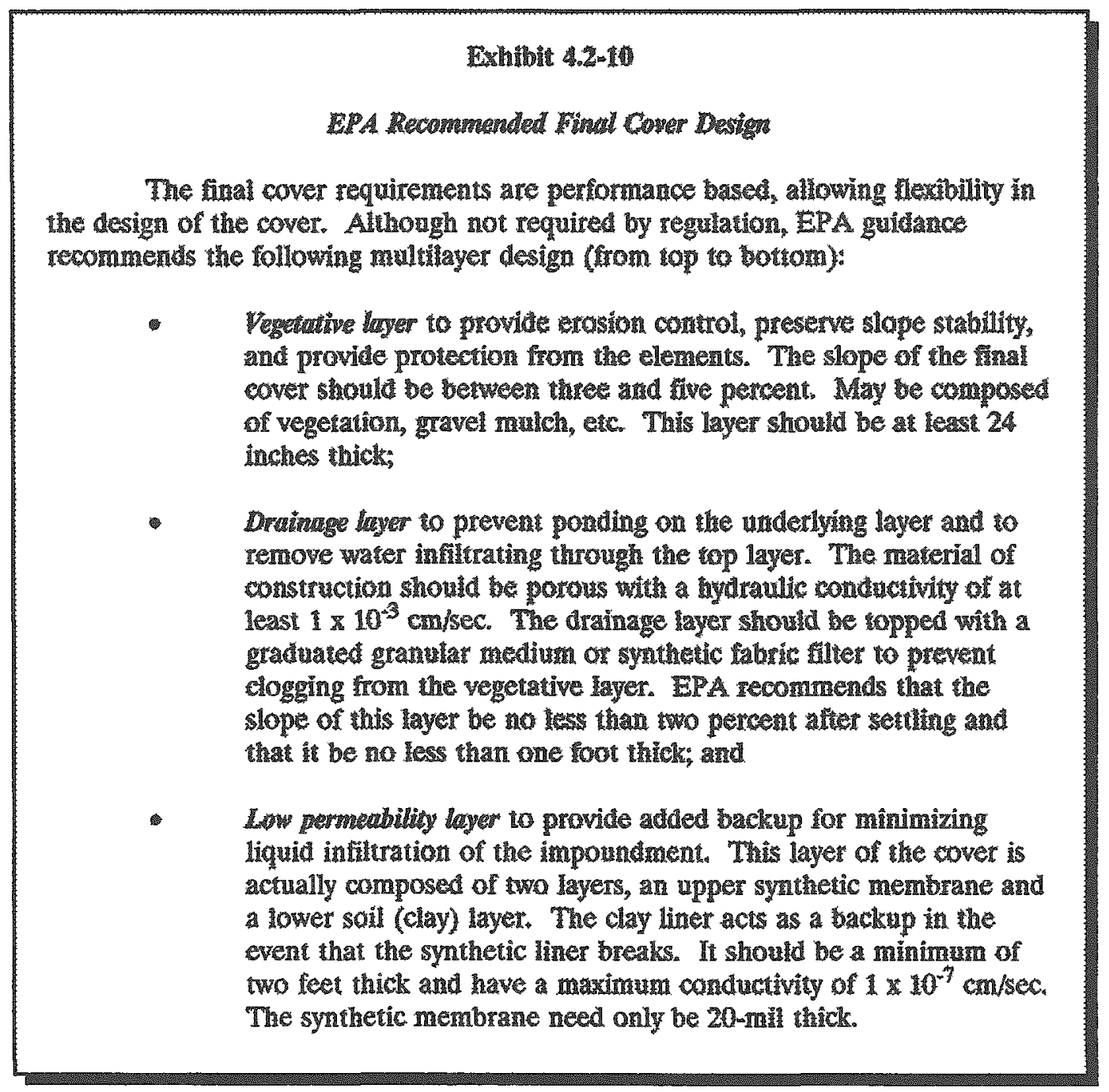

In the event that EPA's recommended closure system does not meet the specific needs of a site, an alternate design may be proposed. The design of the final cover must account for settlement and subsidence of the waste in the impoundment which may affect the integrity of the final cover. EPA-600/285/035 "Settlement and Cover Subsidence of Hazardous Waste Landfills" (1985) provides guidance on this topic. In general, the final cover design should account for the total estimated settlement, including consolidation of soils, foundation materials, the leachate collection system, and final cover. 
EPA also recommends that a Construction Quality Assurance (CQA) program be implemented for the purposes of ensuring that the final cover system meets all design criteria, plans, and specifications. Technical guidance on CQA programs has been provided by the EPA and is available in EPA-530/SW-85. 021, "Construction Quality Assurance for Hozardous Waste Land Disposal Facilities, Public Comment Document' (1985).

Several guidance documents are available from the EPA on interpreting these requirements and on the design of final covers, including:

- "Technical Guidance Document: Final Covers on Hazardous Waste Landfills and Surface Impoundments," EPA/530-SW-89-047, July 1989.

- Draft RCRA Guidance Document on Surface Impoundments Liner Systems, Final Covers, and Freeboard Control," July 1982; and

- "Evaluating Cover Systems for Solid and Hazardous Waste," EPA SW867, GPO\# 055-000-00228-2. This manual provides a guide to examining soil, topographical, and climatological data and recommends cover evaluation procedures.

\subsubsection{Post-Closure Care Activities for Landfull Closure of Surface Impoundments}

The post-closure care period begins upon closure of each unit and is required for 30 years thereafter, unless a different period is established by the Regional Administrator. Activities to be performed during the post-closure care period include:

- Maintenance of the integrity and effectiveness of the final cover, including making repairs to the cap as necessary to correct the effects of settling, subsidence, erosion, or other events;

- Maintenance and monitoring of the leak detection and leachate collection systems at permitted units, in cases where such systems are present;

- Maintenance and monitoring of the ground-water monitoring system and comply with all other applicable requirements of 40 CFR Part 264 Subpart F for permitted facilities and interim status facilities that received waste after July 26,1982 . At a minimum, the detection monitoring wells must be capable of sampling specific conductance, total organic carbon, total organic halogen, and other applicable waste constituents; and

- Prevention of erosion and other damage to the final cover from run-on and run-off.

The frequency of monitoring and maintenance activities is dependent on the specific site conditions, e.g., climate, waste type, soil, and vegetation. 


\subsubsection{Additional RCRA Requeirements to Consider}

In addition to the unit-specific closure requirements discussed in this section, the owner or operator should also be aware of the following additional RCRA requirements.

- Corrective Action. Corrective action at facilities handling mixed waste may be required as a part of, or concurrently with, closure activities. See Section 2.1.3.2 for a discussion of corrective action requirements.

- Land Disposal Restrictions (LDRs). LDRs prohibit the land disposal of RCRA hazardous wastes beyond certain statutory dates established by Congress in HSWA Restricted hazardous wastes and contaminated soils removed at closure are subject to LDRs. See Section 2.1.4 for a discussion of the LDR program.

- Delisting. If the owner or operator of a facility is able to delist the hazardous component of a mixed waste at closure, the waste is no longer subject to the requirements under RCRA. The delisted material becomes a radioactive waste regulated solely by the DOE. However, delisting a waste does not necessarily exempt the facility that handled the waste from RCRA closure requirements. See Section 2.1.2.5 for a discussion of delisting petitions. 


\section{REFERENCES: SECTION 4.2}

DOE 5480.11, "Radiation Protection for Occupational Workers," December 21, 1988.

DOE 5484.1, "Environmental, Safety, and Health Protection Information Reporting Requirements," February 24, 1981.

DOE 5820.2A, "Radioactive Waste Management," September 26, 1988.

"Draft RCRA Guidance Document, Landill Design, Liner Systems and Final Cover," July 1982.

"Draft RCRA Guidance Document on Surface Impoundments, Liner Systems, Final Covers, and Freeboa Control," July 1982.

ECAO-CIN-475, "Verified Reference Doses of U.S. EPA," January 1986.

EPA/530-SW-84-009, "User's Guide for the Hydrologic Evaluation of Landfill Performance (HELP) Model."

EPA/530-SW-85-021, "Construction Quality Assurance for Hazardous Waste Land Disposal Facilities, Public Comment Document," 1985.

EPA/530-SW-86-017, "Interim Status Surface Impoundments Retrofitting Variances," July 8, 1986.

EPA/530-SW-89-047, "Technical Guidance Document: Final Covers on Hazardous Waste Landfills and Surface Impoundments," July 1989.

EPA/540/2-88-004, "Technical Screening Guide for CERCLA Soils and Sludges," September 1988.

EPA/600/2-85-028, "Guide for Decontaminating Buildings, Structures, and Equipment at Superfund Sites," 1985.

EPA/600/2-85-035, "Settlement and Cover Subsidence of Hazardous Waste Landfills," 1985.

EPA/625/6-85-006, "Handbook: Remedial Action at Waste Disposal Sites (Revised)," October 1985.

EPASW-867, "Evaluating Cover Systems for Solid and Hazardous Waste," 1982 (GPO\#055-000-00228-2).

EPA/SW-870, "Lining of Waste Impoundment and Disposal Facilities," July 8, 1986.

EPASW-872, "Guide to the Disposal of Chemically Stabilized and Solidified Waste," September 1982.

EPA/SW-873, "Closure of Hazardous Waste Surface Impoundments," 1982.

EPA's "Health Assessment Document for Tetrachloroethylene (Perchloroethylene)," July 1988. 
EPA's "Minimum Technology Guidance on Double Liner Systems for Landfills and Surface Impoundments: Design, Construction, and Operation," May 24, 1985.

EPA's "RCRA Ground-water Monitoring Compliance Order Guidance (Final)," August 1985.

EPA's "RCRA Ground-water Monitoring Enforcement Guidance, Part II: RCRA Ground-water Monitoring Technical Enforcement Guidance Document (TEGD)."

"Guidelines for Dewatering/Densifying Confined Dredged Material," U.S. Waterways Experiment Station Technical Report DS-78-11.

NRC's "Alternate Concentration Limit Workshop," October 21, 1988.

OSWER Policy Directive \#9285.4-1, "Superfund Public Health Evaluation Manual," 1986.

OSWER Policy Directive \#9476.00-5, "Draft RCRA Guidance Manual for Subpart G Closure and Postclosure Care Standards and Subpart H Cost Estimating Requirements," January 1987.

OSWER Policy Directive \#9476.00-18, "Guidance on Demonstrating Equivalence of Part 265 Clean Closure with Part 264 Requirements," May 12, 1989.

OSWER Policy Directive \#502-00-60, "RCRA Facility Investigation Guidance," May 1989.

OSWER Policy Directive $\# 9950.1, " R C R A$ Ground-water Monitoring Technical Enforcement Guidance (TEGD)," 1986.

U.S. Army's, "Engineering and Design--Laboratory Soils Testing, Appendix VII," (EM 1110-2-1906). 


\section{WASTE PILES}

This section presents the requirements for closure and post-closure care of waste piles containing hazardous and radioactive mixed wastes located at DOE facilities. According to 40 CFR $\$ 260.10$, a hazardous waste pile is defined as a non-containerized accumulation of solid, non-flowing hazardous waste that is used for treatment or storage. The purpose of a waste pile is not to intentionally dispose of wastes; waste piles are used to accumulate waste before shipment, treatment, or disposal. Waste piles are generally small and are often composed of a single material.

\subsubsection{What Are the Closure Requirements for Waste Piles?}

Exhibit 4.3-1 presents an overview of the key closure requirements for waste piles and references to where in this section more detailed information is provided.

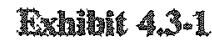

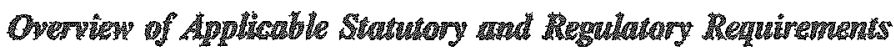

Closnre of waste piles involves a wo tiered procedure - clean closure must finst be attempted. If an hazartous waste camot practicably be removed or decontaminated,

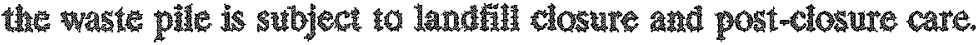

Section 4.3 .2

Waste piles closed mater interim satutus prior to March 19, 1987, must submit an "equivalency demonstration" indicating that the closure satiofies Part 264 standards. If clean closure cantot be uemonstrated, a post-closure pemit must be obained.

Section 4.3 .2 .4

Waste piles that do not comply with the double liner regutrements and are not exempt must prepare contiongent closure and post-closure plans describing how the unit will be cosed as a lanufill and mankained during the post-closure period.

Section 4.3 .2 .2

\subsubsection{Suaturory Requirements}

There are no specific statutory requirements addressing the closure of waste piles. The statutory requirements for waste piles focus upon basic design and operating standards, which affect the applicable requirements during the posi-closure period, if post-closure care is required. RCRA Section 3005(i) requires 
that all interim status waste piles that received hazardous waste after July 26,1982 , comply with ground-water monitoring and corrective action standards that apply to new facilities.

An overview of the relevant ground-water monitoring and corrective action requirements for closures is located in Chapter 2 of this manual; ground-water monitoring and corrective action regulatory requirements are found in 40 CFR Parts 264 and 265, Subpart F.

Section 3004(p) states, however, that the Regional Administrator can exempt a waste pile from the preceding requirements if it:

- Does not receive or contain liquid waste and is designed and operated to exclude run-off;

- Utilizes multiple leak detection systems during the entire active life of the facility (including the closure and post-closure periods); and

- The Regional Administrator concludes that hazardous constituents will not migrate outside of the facility before the post-closure monitoring period ends.

\subsubsection{Regullowory Requirements}

The technical requirements pertaining to the closure of permitted and interim status waste piles are found in 40 CFR $\$ \$ 264.258$ and 265.258 respectively. Exhibit $4.3-2$ describes the closure procedure for waste piles.

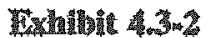

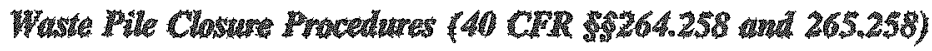

Owners or operators of all waste pilles must:

- Clean Close he Wraste Pille

*- Remowe or decontaminate all waste residues, containment system components, subsoils, structures and equzipment

- No post-closure care required

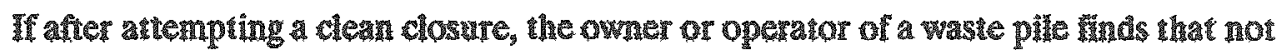
all contamanded subsoils can be practicably decontaminated or removed, then the ower or operator must:

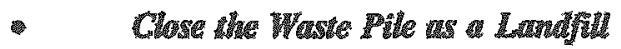

$\rightarrow$ Stabitize subsoils, 隹 necessary;

- Place inpermeable cap over the uniti; and

- Conduct 30 years of post-closure care. 
These requirements are in addition to the general and procedural requirements found in Subpart $G$, which are discussed in Chapter 3 of this manual.

Design Requirements. Both permitted and new units, replacement units, or lateral expansions of existing interim status waste piles are required to meet certain design standards set forth in \$264.251. According to these standards a waste pile must have:

- A liner designed to prevent migration of wastes out of the pile into the soil, ground-water, or surface water for the duration of the waste pile's active life;

- A leachate collection and removal system;

- Run-on control and run-off management systems; and

- A wind dispersion control system, where appropriate.

Liner Requiremonts and Contingen Closure Plans. If a permitted waste pile does not comply with these liner requirements and is not exempt because it is inside or similarly protected from precipitation (\$264.250(c)) nor granted exempt status by the Regional Administrator (\$264.251(b)), the owner or operator must prepare both a contingent closure and post-closure plan describing how the waste pile will be closed. Owners or operators of waste piles designed in accordance with the liner standards are not required to prepare contingent plans. More information on contingent closure and post-closure plans can be found in Section 4.3.2.2.

Equaivalency Demonstrations. Any interim status waste pile that received wastes after July 26, 1982, and clean closed under Part 265 prior to March 19, 1987, must submit an "equivalency demonstration" showing that the closure satisfies all the requirements specified for permitted facilities in Part 264, even if the facility was otherwise subject to the interim status requirements. If clean closure cannot be demonstrated, then a postclosure permit must be obtained for the unit. More information on equivalency demonstrations can be found in Section 4.3.2.4.

\subsubsection{Clean Closure of Waste Pilles}

In order to close a waste pile, clean closure must be attempted first. The goal of clean closure is to remove or decontaminate all materials on-site that could potentially lead to future contamination. The technical requirements for clean closure are found in 40 CFR \$\$264.258 and 265.258, and are roughly equivalent under the current regulations for permitted and interim status facilities. Under these requirements, all waste residues, containment system components, liners, subsoils, contaminated equipment, and structures must be decontaminated or removed from the site. These components must then be managed as hazardous waste unless specifically exempted under $40 \mathrm{CFR} \$ 261.3$.

The following is an overview of the required clean closure activities for owners or operators of waste piles:

- Prepare closure plan (Section 4.3.2.1);

- Prepare contingent closure and post-closure plans, if appropriate; (Section 4.3.2.2); 
- Conduct closure (Section 4.3.2.3); and

- Demonstrate clean closure (Section 4.3.2.4).

The following sections provide guidance on how to properly perform the activities listed above.

\subsubsection{Preparing Wraste Pile Cleane Closure Plans}

A written closure plan for a waste piles must contain the general information required by $40 \mathrm{CFR}$ Parts 264 and 265, Subpart $G$, in addition to the technical information found in Subpart $L$. An outline for a sample closure plan for a waste pile is presented in Exhibit 4.3-3.

Establishment of Contumination Clemup Targets. The closure plan must include a listing of the exposure limits for all hazardous constituents which may have been generated, used, stored, or disposed at the unit. These constituents include, but are not limited to, those listed in 40 CFR Part 261, Appendix VIII. The exposure limits will be used as standards at the time of closure for assessing whether or not removal and decontamination activities are complete. The exposure limits chosen in the plan for the hazardous component of the mixed waste should be an EPA recommended limit if one exists. While the radioactive component of the waste is not subject to RCRA regulation, it may be appropriate in many cases to address these contaminants in the closure plan.

If no EPA recommended limits exist for the contaminants of concern at a waste pile, other options the owner or operator may wish to consider are:

- Remove the constituent to background levels; or

- Submit toxicity data on the constituent using the procedures outlined in the Toxic Substance Control Act to show that contaminants do not pose a threat at the point of exposure; or

- Close the waste pile as a landfill.

Radiation Exposure Limits. Although not required under RCRA, DOE requires that external exposure to the radioactive component of low level mixed waste from all environmental medium, plants, and animals, not exceed an effective dose equivalent of 25 mrem/year to any member of the public. The concentration of a radionuclide may be determined by direct methods or by indirect methods such as the use of scaling factors which relate the inferred concentration of one radionuclide to another that is measured, if there is reasonable assurance that the indirect methods can be correlated with actual measurements. Radiation standards and concentration guides applicable to DOE operations are found in DOE 5480.11, Radiation Protection for Occupational Workers, December 21, 1988. 
Exhibit 4.3-3

WASTE PILE CLEAN CLOSURE PLAN SAMPLE OUTLINE

Section

Elements

Facillity Conditions

Removal of Inventory

Facility Decontamination

Clean Closure Demonstration

Ground-Water \& Monitoring Evgluation

Security Systems

Survey Plat

Closure Certification
- Facility location and size;

- Topographic map:

- List of other hazardous waste management units and wastes handled in each;

- Hydrogeological information;

- Waste pile description (number, size, type of liner system, etc.);

- References to other environmental permits; and

- Anticipated waivers or exemptions.

- Estimates of inventory to be removed; and

- Procedures for handling removed inventory.

- Procedures for decontamination or disposal of pad, liner, containment area, equipment and soil;

- Major radionuclides and their concentrations; and

- Procedures for leachate management.

- Listing of exposure limits for Appendix VIII constituents;

- Background levels at the site; and

- Description of the testing to determine if liner, equipment, etc. are hazardous

- $\quad$ Procedures for monitoring analysis; and

- Number, location, and frequency of samples.

- General description.

- Surveyed benchmarks.

- $\quad$ Activities to be conducted; and

- Documentation. 
Exhibit 4.3-3 (Continued)

WASTE PILE CLEAN CLOSURE PLAN SAMPLE OUTLINE

- Expected year of closure (only for interim status facilities without approved closure plans);

- Time required for waste treatment, removal, decontamination, and final closure; and

- Support for deadline extensions, if applicable.

Source: OSWER Policy Directive No. 9476.00-5, "RCRA Guidance Manual for Subpart G Closure and PostClosure Care Standards and Subpart $H$ Cost Estimating Requirements (Draft)" 
Wastes containing amounts of radionuclides below regulatory concern (BRC) may be disposed without regard to radioactivity content (DOE 5820.2A, Radioactive Waste Management, September 26, 1988). The NRC is developing a rule governing the disposal of radioactive waste determined to be below regulatory concern. It is expected that such a rule may establish a risk or dose value that would represent generic regulatory cut-off levels for radioactive wastes. If DOE does not adopt this rulemaking, this requirement is not applicable.

The subsoil at the facility should be sampled and analyzed when the Part B application is prepared and the results should be included in the closure plan. The results may later be used as target levels for demonstration of clean closure. Background levels must be established for ground-water, soil, and surface water (if appropriate), and must reflect the natural or existing local conditions unaffected by operations of the unit.

If the waste pile contains mixed wastes, the monitoring program should also comply with the requirements found in DOE 5484.1. Environmental, Safety, and Health Protection Information Reporting Requirements, Februkry 24, 1981.

\subsubsection{Preparing Contingent Closure and Post-Closure Plans}

The owner or operator of any permitted waste pile that is not designed in accordance with the liner design standards specified in $\$ 264.251$ (a), and is not protected from precipitation and therefore exempt under $\$ 264.251$ (c), or has not been exempted by the Regional Administrator in accordance with $\$ 264.251$ (b), must prepare a contingent closure plan. This plan describes how the waste pile will be closed as a landfill if clean closure cannot be achieved. In addition, a contingent post-closure plan describing 30 years of post-closure monitoring and maintenance activities is also required. Outlines for sample contingent closure and postclosure plans for a waste pile are presented in Exhibit 4.3-4 and 4.3-5 respectively. Owners or operators of interim status facilities without ground-water monitoring systems in place will be required to install such a system at closure if post-closure care is required.

The owner or operator of a waste pile that complies with the liner design standards specified in $\$ 264.251$ (a), or is exempt from them in accordance with $\$ 264.251$ (b) or $\$ 264.251$ (c), need not prepare a postclosure plan unless clean closure cannot be achieved and the unit must be closed as a landfill. Note that a revised closure plan will also be required (see Section 4.3.3.1).

\subsubsection{Implementings Clecten Closure of Waste Pilles}

In order to properly clean close a waste pile, all wastes, waste residues, contaminated containment system components (e.g., liners), contaminated subsoils, and structures and equipment contaminated with waste and leachate must be either removed or decontaminated (Section 4.2.3.4 may be a useful reference).

All removed materials must be managed as hazardous waste unless the wastes has been delisted (specified in 40 CFR $\$ 261.3$ (d) and discussed in Section 2.1.2.5). In addition, if these materials are mixed wastes, they must be managed in accordance with DOE 5280.2A, Radioactive Waste Management, September 26, 1988. Mixed wastes containing transuranic materials must be managed at the Waste Isolation Plant (WIPP), unless the wastes do not meet acceptance criteria. Information on WIPP acceptance criteria is provided in DOE 5820.2A, Radioactive Waste Management, September 26, 1988. 
Exhibit 4.3.4

WASTE PILE CONTINGENT CLOSURE PLAN SAMPLE OUTLINE

Section

Elements

Inventory Removal

Freility Decontamination

Final Cover Design

Ground-Water Monitoring

Security Systems

Survey Plat

Closure Certififation

Closure Schedule
- Estimates of inventory to be removed and

- Procedures for handling removed inventory.

- Procedures for decontamination or disposal of pad, liner, containment area, equipment, and soil.

- Engineering drawings and area covered;

- Cover characteristics (e.g., material type, permeability, depth, slope, drainage structures, and vegetation;

- Installation procedures;

- Erosion control procedures; and

- Procedures for soil stabilization.

- Well installation;

- Types of analysis; and

- Equipment maintenance.

- General description and

- Description of proposed changes.

- Surveyed benchmarks.

- Activities to be conducted and

- Documentation

- Milestone chart showing closure cover installation, vegetation planming, and total time to complete closure.

Source: OSWER Policy Directive No. 9476.00-5, "RCRA Guidance Manual for Subpart G Closure and PostClosure Care Standards and Subpart H Cost Estimating Requirements (Draft). 
Exhibit 4.3-5

WASTE PILE CONTINGENT POST-CLOSURE PLAN SAMPLE OUTLINE

Ground-Water Monitoring

Soil Monitoring

Leachate Monitoring and Removal

Inspections

Maintenance Activities
- Number, location, and depth of wells installed;

- Frequency of sampling; and

- Types and procedures for analyses.

- Number and frequency of samples;

- Sampling procedures; and

- Types of analyses conducted.

- Frequency and procedures for monitoring;

- Estimated quantity of leachate;

- Procedures for collection and removal of leachate; and

- Leachate treatment and disposal procedures.

- Frequency; and

- Scope.

- Final cover;

- Monitoring systems; and

- Security systems.

Source: OSWER Policy Directive No. 9476.00-5, "RCRA Guidance Manual for Subpart G Closure and PostClosure Care Standards and Subpart H Cost Estimating Requirements (Draft)". 
Before disposing of any of the wastes in a landfill, injection well, or any other land disposal unit, the owner or operator should determine if the wastes are prohibited from land disposal under the land disposal restrictions (LDRs). If the waste is restricted from land disposal, it must be treated by a method that meets the treatment standards of 40 CFR $\$ \$ 268.40$ through 268.44 .

Liner Removal. The waste pile liner should be removed following waste removal and before removal of any subsoils to minimize the potential for additional contamination of the subsoil. Normal excavation methods can be used to remove liners made of clay and soil. However, concrete or gunnite liners should first be broken up and then removed. Flexible membrane liners should be removed in small subsections, in a similar manner in which they were installed. Guidance on liner removal can be found in EPA/SW-873, "Closure of Hazardous Waste Surface Impoundments," 1982.

Soils Removal. Soils underlying the waste pile must be tested at this point to determine the extent of contamination. Any soils which have been determined to contain contaminants in excess of the exposure limits specified in the closure plan must be removed. The soil should be removed in layers and sampling conducted following removal of each layer. This procedure will help minimize the amount of soil removed. Excavation should be completed as quickly as possible to reduce the probability of rain transporting contaminants through the unsaturated zone.

Equipment Decontuminution. The regulations require owners or operators of waste piles to decontaminate all equipment, tools, supplies, etc, involved in operating, maintaining, and closing the unit. Guidance on procedures for equipment decontamination are provided in EPA/600/2-85/028, "Guide for Decontaminating Buildings, Structures, and Equipment at Superfund Sites," 1985.

\subsubsection{Demonstrating Clean Clasure}

To demonstrate clean closure, the owner or operator must test the soil and ground water surrounding the waste pile to document that the contaminants left in the subsoils will not impact the ground water, surface water, or the atmosphere, in excess of the exposure limits specified in the facility's approved closure plan.

Ground-Weter Pathway. To make the demonstration of clean closure with respect to the ground-water pathway, the following actions must be taken:

- Remove contaminated soil and saturated subsoils to demonstrate that constituent levels in ground water do not exceed EPA-sstablished chronic health levels (based on RID or CSF values); and

- Show that residual contaminant levels remaining in the soil will not contribute to any future contamination of ground-water by showing that levels of constituents found in leachate are not above the EPA-established exposure levels. Levels of constituents in leachate may be estimated based on known characteristics of the waste constituents or determined by the results of actual soil leaching tests.

Direct Contact Pathway. To make the demonstration of clean closure with respect to the direct contact pathway, demonstrate upon closure that contaminant levels in soils are less than levels established by EPA 
as acceptable for ingestion or dermal contact. Soil core samples must be collected at random sampling points over the entire area of the unit.

Air Exposures. The analysis of potential air exposures should assess contaminants migrating from the soils into the atmosphere. The demonstration should include:

- Emission calculations;

- Available monitoring data; and

- Safe inhalation levels based on EPA-established exposure levels.

Surface Water Exposures. The potential surface water exposure analysis should compare EPAestablished water quality standards and criteria (45 FR 79318, November 28, 1980) with the levels of constituents that may leach from the residual contaminated soil. The surface water exposure analysis should also consider existing surface water contaminant concentrations.

Preparing Equivalency Demonstrations. A special requirement applies to all waste piles that received wastes after July 26, 1982, and certified clean closure under the Part 265 requirements prior to March 19, 1987. These units must submit an equivalency demonstration, which demonstrates that closure satisfies all the requirements specified for permitted facilities in Part 264, even if the facility has operated and is otherwise subject to the Part 265 interim status requirements. Sections 270.1 (c)(5)-(6) outline the procedures for determining if the closure met Part 264 standards. Basically, clean closure may be demonstrated in one of the following ways:

- If the facility has submitted a Part B application for a post-closure permit, it is possible to request a determination based upon the information contained in the application; or

- If the facility has not submitted a Part B application for a post-closure permit, it is possible to petition the Regional Administrator for a determination. The petition must include all the data necessary to demonstrate that closure by the removal or decontamination standards in $\$ 264.228$ were met or that the unit closed under State requirements that meet or exceed $\$ 264.228$.

The owner or operator will be notified within 90 days of submission as to whether or not the demonstration has been approved (40 CFR \$270.1). If upon review of the equivalency demonstration, EPA determines that the closure does not meet the Part 264 standards, the facility will be required to submit a postclosure permit application addressing all applicable Part 264 requirements, including ground-water monitoring, corrective action, and post-closure care (see section on landfill closures for guidance on post-closure permits and procedures). The facility may submit additional information to the Regional Administrator in support of the equivalency demonstration along with a request that the demonstration be reevaluated. This request must be submitted within 30 days of receipt of notice of denial by the Regional Administrator. A final determination will be provided within 60 days of the second submittal. 
EPA guidance on equivalency demonstrations is provided in OSWER Policy Directive \#9476.00-18, "Guidance on Demonstrating Equivalence of Part 265 Clean Closure With Pant 264 Requirements," May 12, 1989.

If clean closure cannot be demonstrated or if after attempting to clean close a waste pile it becomes apparent that clean closure is not practicable due to widespread contamination, the unit must be closed as a landfill and a post-closure permit must be obtained for the unit (see Section 4.3.3).

\subsubsection{Landfill Closure of Waste Piles}

Waste piles without liners are likely to require landfill closure because of the probable contamination of large amounts of subsoil. Waste piles that have liners installed in accordance with $40 \mathrm{CFR} \$ 264.251$ that later fail, may have contaminated underlying ground water and would also require landfill closure. The following is an overview of the required activities for owners or operators of waste piles who, after first attempting clean closure, must close their unit(s) as a landill:

- Revise closure plan (Section 4.3.3.1);

- Prepare post-closure plan (Section 4.3.3.2);

- Conduct closure (Section 4.3.3.3); and

- Conduce post-closure care (Section 4.3.3.4).

\subsubsection{Preparing Landfill Clasure Plans at Waste pilles}

A written plan for a landfill closure of a waste pile will contain much of the same information as did the original clean closure plan. Some revisions to take into account the elements particular to landfill closure will also be required. Moreover, the revised closure plan will be essentially the same as the contingent closure plan required for waste pile units with substandard liners, if such a plan was required (see Exhibit 4.3-4). Thus the revised closure plan of a waste pile that requires landfill closure need not involve an excessive amount of work.

\subsubsection{Landfill Closure Post-Closure Plane Requirements}

Owners or operators of waste piles which are closed as landfills are required to conduct post-closure care for 30 years after closure and must comply with all post-closure procedural requirements contained in $40 \mathrm{CFR} \$ \$ 264.117$ through 264.120 , including maintenance and monitoring throughout the post-closure care period. The EPA Regional Administrator has the authority to extend or reduce the period for post-closure care on a case-by-case basis. Exhibit 4.3-6 outlines closure activities for waste piles closed as landfills.

As is the case for landfill closure plans, post-closure plans for waste piles closed as landfills will closely resemble a contingent post-closure plan, if one was required (see Exhibit 4.3-5). However, because the contingent closure plan would have been prepared much earlier (during the permit application process), it will probably require some revision. Owners or operators of waste piles that met liner requirements or were exempt, and were therefore not required to prepare a post-closure plan, must prepare such a plan if clean closure was not practicable. 


\subsubsection{Required Activities for Landfill Closure}

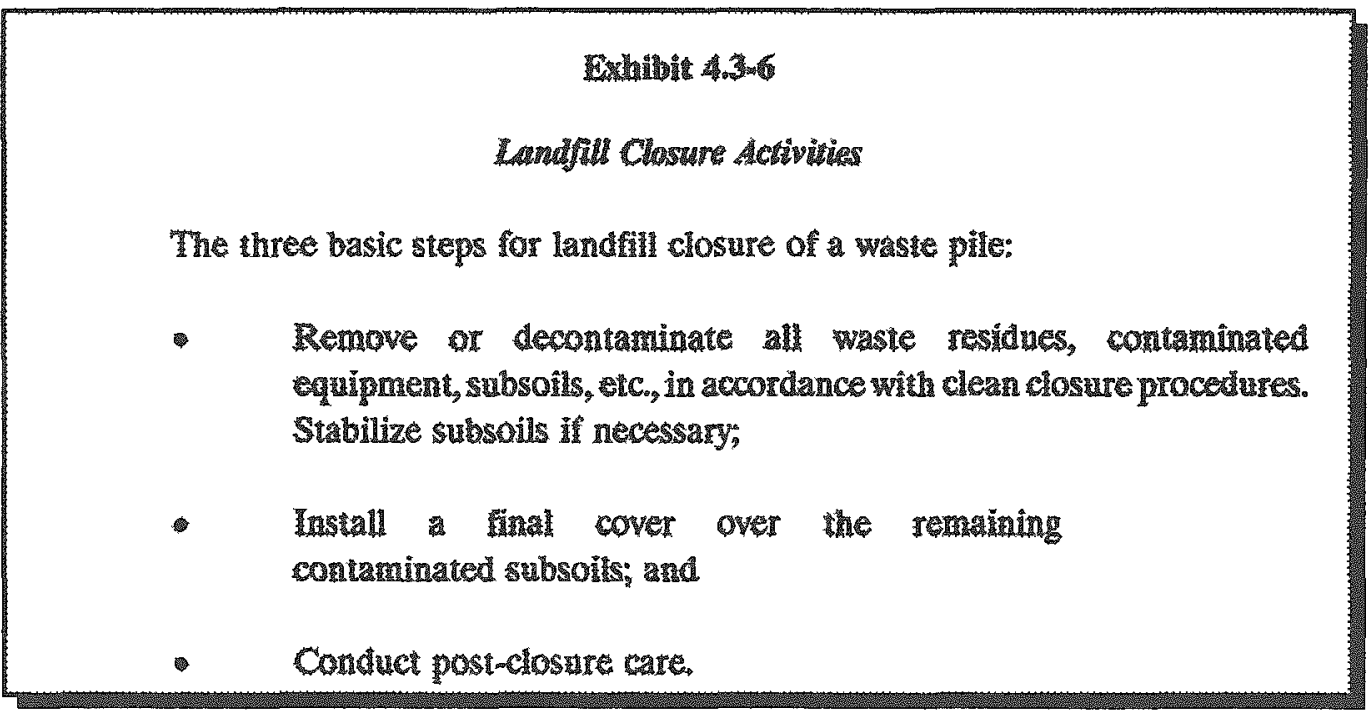

Waste Removal. The requirements and procedures for removing waste from a waste pile are described in Section 4.3.2.3. All wastes must be removed from a waste pile, even if the facility is eventually closed as a landfill. If clean closure is not practicable, only contaminated subsoils can be left behind in the landfill.

Finul Cover. The remaining contaminated subsoils in the waste pile must be covered with a final cover to provide long term minimization of precipitation and run-off into the closed waste pile. The standards for final covers are discussed in Section 4.1, Landfills. A list of EPA guidance documents on the design of final covers can also be found in Section 4.1 of this manual. The purpose of the final cover is to:

- Minimize the long-term prospects of migration of liquids through the landfill;

- Function with minimum maintenance;

- Promote drainage and minimize erosion and abrasion of the cover;

- Accommodate settling and subsidence; and

- Have a permeability less than or equal to the permeability of any bottom liner or subsoils present.

Further guidance on final covers is provided in EPA/SW-867, "Evaluating Cover Systems for Solid and Hazardous Waste."

Alternate cover designs are allowable as long as they account for settlement and subsidence of the waste which may affect the integrity of the final cover. EPA-600/2-85/035 "Settlement and Cover Subsidence of Hazardous Waste Landfills" (1985) provides guidance on this topic. 
EPA also recommends that a Construction Quality Assurance (CQA) program be implemented for the purposes of ensuring that the final cover system meets all design criteria, plans, and specifications. Technical guidance on CQA programs has been provided by the EPA and is available in EPA-530/SW-85-021, "Construction Quality Assurance for Hazardous Waste Land Disposal Facilities, Public Comment Document' (1985).

\subsubsection{Post-Closure Care Requirements for Lamdifll Clasures}

The post-closure care period is 30 years from the date of closure, unless a different period is established by the Regional Administrator. Activities to be performed during the post-closure care period include:

- Maintenance of the integrity and effectiveness of the final cover, including making repairs to the cap as necessary to correct the effects of settling, subsidence, erosion, or other events;

- Permitted units are required to maintain and monitor the leak detection and leachate collection systems, in cases where such systems are present;

- Maintenance and monitoring of the ground-water monitoring system and comply with all other applicable requirements of 40 CFR Part 264 Subpart F for permitted facilities and interim status facilities that received waste after July 26, 1982. At a minimum, the detection monitoring wells must be capable of sampling specific conductance, total organic carbon, total organic halogen, and other applicable waste constituents. Note that if the waste pile was an interim status facility, it is likely that the ground-water monitoring system used will not satisfy these requirements. If this is the case, the existing system must be upgraded or a new one installed. Technical guidance on ground-water monitoring can be found in OSWER 9950.1, "RCRA Ground-Water Monitoring Technical Enforcement Guidance Document, September 1986."

- Prevention of erosion and other damage to the final cover from run-on and run-off.

All other generic Subpart $G$ closure and post-closure care requirements aiso apply to the closure of interim and permitted waste piles and are discussed in Chapter 3.

\subsubsection{Additional RCRA Requirements to Consider}

In addition to the unit-specific closure requirements discussed in this section, the owner or operator should also be aware of the following additional RCRA requirements.

- Corrective Action. Corrective action at facilities handling mixed waste may be required as a part of, or concurrently with, closure activities. See Section 2.1.3.2 for a discussion of corrective action requirements. 
- Land Disposal Restrictions (LDRs). LDRs prohibit the land disposal of RCRA hazardous wastes beyond certain statutory dates established by Congress in HSWA Restricted hazardous wastes and contaminated soils removed at closure are subject to LDRs. See Section 2.1.4 for a discussion of the LDR program.

- Delisting. If the owner or operator of a facility is able to delist the hazardous component of a mixed waste at closure, the waste is no longer subject to the requirements under RCRA. The delisted material becomes a radioactive waste regulated solely by the DOE. However, delisting a waste does not necessarily exempt the facility that handled the waste from RCRA closure requirements. See Section 2.1.2.5 for a discussion of delisting petitions. 
REFERENCES: SECTION 43

DOE 5480.11, "Radiation Protection for Occupational Workers," December 21, 1988.

DOE 5484.1, "Environmental, Safety, and Health Protection Information Reporting Requirements," February $24,1981$.

DOE 5820.2A, "Radioactive Waste Management," September 26, 1988.

EPA/530-SW-85-021, "Construction Quality Assurance for Hazardous Waste Land Disposal Facilities, Public Comment Document," 1985.

EPA/600/2-85-028, "Guide for Decontaminating Buildings, Structures, and Equipment at Superfund Sites," 1985.

EPA/600/2-85-035, "Settlement and Cover Subsidence of Hazardous Waste Landfills," 1985.

EPA/625/6-85-006, "Handbook: Remedial Action at Waste Disposal Sites (Revised)," October 1985.

EPA/SW-867, "Evaluating Cover Systems for Solid and Hazardous Waste," 1982 (GPO\#055-000-00228-2).

EPA/SW-873, "Closure of Hazardous Waste Surface Impoundments," 1982.

OSWER Policy Directive \#9476.00-5, "Draft RCRA Guidance Manual for Subpart G Closure and Post-closure Care Standards and Subpart H cost Estimating Requirements," U.S. EPA, January 1987.

OSWER Policy Directive $\$ 476.00-18$, "Guidance on Demonstrating Equivalence of Part 265 Clean Closure with Part 264 Requirements," May 12, 1989.

OSWER Policy Directive \#9950.1, "RCRA Ground-water Monitoring Technical Enforcement Guidance Document (TEGD)," September 1986. 


\section{LAND TREATMENT}

This section presents the requirements for closure and post-closure care of land treatment facilities treating hazardous and mixed wastes located at DOE facilities. A land treatment facility is defined in $40 \mathrm{CFR}$ $\$ 260.10$ as, a facility or part of a facility at which hazardous waste is applied onto or incorporated into the soil surface. The portion of a land treatment facility within which the hazardous constituents are degraded, transformed, or immobilized is known as the treatment zone. 40 CFR \$264.271(c) states that the maximum depth of the treatment zone must be no more than five feet from the initial soil surface and no less than three feet above the seasonal high water table.

Land treatment facilities differ from other land disposal facilities in that they are not designed to minimize liquid release to ground water (e.g., through the use of liners). Instead, they are open systems that allow liquids to move out of the facility. Facilities designed primarily for the purposes of dewatering without treatment are not land treatment facilities but are considered surface impoundments (see Section 4.2).

\subsubsection{What Are the Closure Requirements for Land Treutment Facilities?}

Exhibit 4.4-1 provides an overview of the key closure requirements for land treatment facilities and references to where in this section more detailed information is provided.

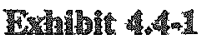

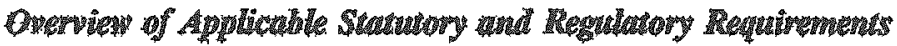

At permitted faciluties, all operations conducted to ensure no taigration of hazardous

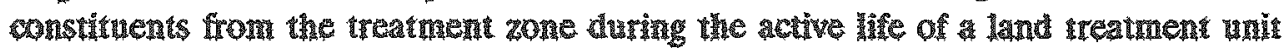
must continue throughout both the closure and posf-closure periods. Interim status facility requirements are somewhat less strimgent.

Section 4.4 .1 .2

The owner or operator of a permitted land treatment acility must apply a protective vegetative cower over the facility al closure, unless he can chenonstrate that the level of

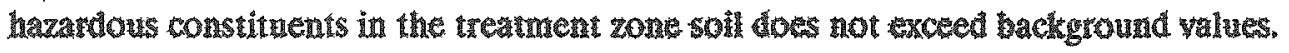
Owners or operators of interim status facilities have the option of applying a vegetative cover, yet they are not reguired to to so.

Section 4.4 .2 .3

Post-losure care at a permitted land treatment facility contrintes until the level of hazardous constituents in the treatment zone soil no longer exceeds background values. Interim statu facilities are subject to 30 yeas of post-losure care unless the agional Administrator approves shorter priod. 


\subsubsection{Statutory Requirements}

RCRA section 3005(i) states that all interim status land treatment facilities that received hazardous waste after July 26,1982 , shall be subject to ground-water monitoring, corrective action, and unsaturated zone monitoring standards that apply to new facilities under Section 3004. Chapter 2 of this manual provides an overview of the RCRA ground-water monitoring and corrective action requirements found in Subpart $F$ of 40 CFR Parts 264 and 265.

In addition to monitoring the upper aquifer in accordance with Subpart $F$, owners or operators of land treatment facilities must also conduct unsaturated (vadose) zone monitoring. Unsaturated zone monitoring requires the operator to sample the soil and soil-pore liquid to determine whether hazardous constituents are migrating from the treatment zone. For permitted facilities and those interim status facilities that received waste after July 26,1982 , the hazardous constituents which are to be monitored are those identified in Appendix IX of 40 CFR Part 264 that are reasonably expected to be in, or derived from, waste placed in the land treatment facility. The technical requirements for unsaturated zone monitoring can be found in $40 \mathrm{CFR}$ $\$ 264.278$ and 265.278 .

\subsubsection{Regulatory Requirements}

The technical requirements pertaining to the closure and post-closure of permitted and interim status land treatment facilities are found in Subpart M of Parts 264 and 265 respectively. Closure and post-closure care requirements for interim status facilities are considerably less stringent than those for permitted facilities. These requirements must be met along with the procedural requirements found in Subpart $G$, which are discussed in Chapter 3 of this manual.

The following is a summary of the principle regulatory requirements for closure and post-closure care of land treatment facilities:

Closure requirements for permitted land treatment facilities (40 CFR \$264.280). At closure, the owner or operator must do the following:

- Cease application of wastes to the treatment zone;

- Continue all operations necessary to maximize degradation, transformation, or immobilization of hazardous constituents;

- Maintain run-on and run-off control systems;

- Control wind dispersion;

- Comply with food-chain crop restrictions;

- Continue unsaturated zone monitoring; and

- Establish and maintain a protective vegetative cover. 
For a permitted facility, post-closure care terminates (or need not even begin) if the owner or operator can demonstrate that concentrations of hazardous constituents in the treatment zone soil do not exceed background levels by a statistically significant amount.

Closure requirements for interim status land treatment facilities (40 CFR \$265.280). At closure, the owner or operator must attempt to control the migration of hazardous constituents or hazardous waste into ground water, surface water or air, and must also comply with food-chain crop restrictions. To achieve these objectives, the owner or operator must consider the following methods:

- Removal of contaminated soils;

- Installation of a final cover; and

- Ground-water monitoring.

In addition, owners or operators of interim status land treatment facilities must do the following:

- Continue unsaturated zone monitoring;

- Maintain run-off and run-on control systems; and

- Control wind dispersion of particulate mater.

Post-closure care at interim status facilities lasts for 30 years unless the Regional Administrator approves a shorter period.

\subsubsection{Closure of Land Treatment Facilities}

Closure of land treatment facilities is somewhat unique because the required activities are a continuation of those conducted during the active life of the facility, except that wastes are no longer applied to the treatment zone. And while the regulatory requirements for interim status facilities are less stringent, the closure activities conducted at both permitted and interim status facilities are similar.

The following is an overview of the required activities for owners or operators of land treatment facilities when they close their facility(s):

- Prepare closure plan (Section 4.4.2.1)

- Prepare post-closure plan (Section 4.4.2.2)

- Conduct closure (Section 4.4.2.3)

- Conduct post-closure care (Section 4.4.2.4) 


\subsubsection{Preparing Land Treatment Facility Closure Plans}

A written closure plan for a land treatment facility must contain the general information required by 40 CFR Parts 264 and 265 Subpart G, in addition to the technical information found in Subpart M. An outline for a sample closure plan for a land treatment facility is presented in Exhibit 4.4-2.

\subsubsection{Preparing Post-Closure Plans}

A written post-closure plan for a land treatment facility must be prepared by the owner or operator, even in the event that post-closure care at a permitted facility is later determined to be unnecessary. The postclosure plan must contain the general information required by $40 \mathrm{CFR} \$ \$ 264.118$ and 265.118 in addition to the technical information found in $\$ \$ 264.280$ and 265.280 . An outline for a sample post-closure plan for a land treatment facility is presented in Exhibit 4.4-3.

\subsubsection{Implementing Land Treatment Facility Closure}

The technical requirements for closure of permitted and interim status land treatment facilities are located in 40 CFR $\$ 264.280$ and 265.280 respectively. The purpose of these requirements is to maximize the degradation, transformation, and immobilization of hazardous constituents within the treatment zone and to ensure that no migration of hazardous constituents occurs. Closing a land treatment facility involves the following steps:

Continuation of degrodation, trunsformation and immobilization. The owner or operator must maintain the $\mathrm{pH}$ level of the soil; many hazardous metals are soluble at low $\mathrm{pH}$ levels and hazardous constituents in solution can readily migrate out of the treatment zone. The moisture level in the treatment zone must also be controlled to avoid migration of hazardous constituents. Because many hazardous wastes disposed of in land treatment facilities are organic, and therefore subject to microbial degradation, the level of microbial activity in the zone must be maintained and enhanced if possible through such measures as fertilization and tilling.

Controlling runnoff, runeon, and wind dispersion. The run-on control system must be capable of preventing flow onto the treatment zone during peak discharge from at least a 25 -year storm. The run-off control system must be able to collect and control at least the water volume resulting from a 24-hour, 25-year storm. The collection and holding facilities associated with these systems must be managed expeditiously to maintain the capacity. Potential control measures for wind dispersion include: maintenance of proper soil moisture, chemical soil stabilizing agents, and the establishment of a vegetative cover (see below).

Continuation of unsaturated zone monitoring. The regulatory requirements for unsaturated zone monitoring are located in $40 \mathrm{CFR} \$ \$ 264.278$ and 265.278 . The purpose of unsaturated zone monitoring is to evaluate the success of the treatment. Unsaturated zone monitoring data are also used to make adjustments to the treatment system and to determine whether or not hazardous constituents are migrating from the treatment zone. 
Exthibitit 4.4.42

LAND TREATMENT CLOSURE PLAN SAMPLE OUTLINE

Section

Elements

\section{Fraility Conditions}

Inventory and Decontamination

Continuation of Land Treatment Processes

Ground-Water Monitoring

Soil Monitoring
- Facility description;

- Topographic map;

- List of other hazardous waste management facilities and wastes handled in each;

- Land treatment system description;

- Hydrogeological information;

- References to other environmental permits; and

- Anticipated waivers and exemptions.

- Estimates of maximum waste volume to be placed on the land; and

- Procedures for handling, disposal, and/or decontamination of other wastes and equipment.

- Procedures for continued degradation of hazardous constituents;

- Procedures for controlling run-on and run-off;

- Procedures for controlling wind dispersal;

- Procedures for complying with food-chain crop restrictions; and

- Procedures for measuring the level of hazardous constituents in the treatment zone.

- Number, location, and depth of wells;

- Frequency of sampling; and

- Types and procedures for analyses.

- Number and frequency of samples;

- Sampling procedures; and

- Types of analyses conducted. 
Demonstration that Posi-Closure Care Not Required, if Applicable

Security Systems

Survey Plat

Closure Certification

Closure Schedulle
- Data showing no statistical increase over background levels in treatment zone; and Data showing no migration from treatment zone.

- General description.

- Surveyed benchmariss.

- Activities to be conducted and

- Documentation.

- Expected year of closure (only for interim status facilities without approved closure plans);

- Closure milestones; and

- Support for deadline extensions, if applicable.

Source: OSWER Policy Directive No. 9476.00-5, "RCRA Guidance Manual for Subpart G Closure and PostClosure Care Standards and Subpart H Cost Estimating Requirements (Draft)". 
Exhibie 4.4-3

LAND TREATMENT POST-CLOSURE PLAN SAMPLE OUTLINE

Section

Elements

Conthumation of Land Treatment Processes

Ground-Water Monitoring

Soil Monitoring

Inspections

Maintenance Activities
- Procedures for continued degradation of hazardous constituents;

- Procedures for controlling run-on and run-off;

- Procedures for controlling wind dispersal;

- Procedures for complying with food-chain crop restrictions; and

- Procedures for measuring the level of hazardous constituents in the treatment zone.

- Number, location, and depth of wells;

- Frequency of sampling; and

- Types and procedures for analyses.

- Number and frequency of samples;

- Sampling procedures; and

- Types of analyses conducted.

- Frequency and

- Scope.

- Vegetative cover;

- Monitoring systems; and

- Security systems.

Source: OSWER Policy Directive No. 9476.00-5, "RCRA Guidance Manual for Subpart G Closure and PostClosure Care Standards and Subpart H Cost Estimating Requirements (Draft)" 
To determine if hazardous constituent migration has occurred, background levels must first be established. Owners or operators of permitted facilities and interim status facilities that received waste after July 26, 1982, must establish background levels for the hazardous constituents identified in Appendix VIII of 40 CFR Part 264 that are reasonably expected to be in, or derived from, waste placed into the treatment zone. Background values for soil may be based on a one time sampling at a plot having similar characteristics to those of the treatment zone, whereas background soil-pore liquid values must be based on at least quarterly sampling for one year at a similar background plot.

Unsaturated zone monitoring below the treatment zone is conducted to determine if there has been any statistically significant increase in the hazardous constituents in question. If an increase is detected, the operator must notify the Regional Administrator within seven days. This notification must indicate which constituents have shown a statistically significant increase.

The owner or operator of a permitted land treatment facility is not subject to post-closure care requirements if he can prove that there has been no statistically significant increase above the background level of hazardous constituents in the treatment zone. In addition, if the owner or operator can also prove that hazardous constituents have not migrated beyond the treatment zone during the active life of the facility, Subpart F ground-water monitoring requirements do not apply.

Additional information on unsaturated zone monitoring at land treatment facilities can be found in "Permit Guidance Manual on Hazardous Waste Land Treatment Demonstrations," Final Draft, July 1986, EPA530.SW-84-015.

Establishment of a protective vegetative cover. The vegetative cover must be designed to minimize liquid migration, promote drainage while controlling erosion, minimize maintenance needs, account for potential settlement and subsidence, have a permeability equal to or less than the permeability of the bottom liners or natural subsoil, and account for freeze/thaw effects. The description in the closure plan must include the name, species, and variety of cover crop; data indicating that the crop can survive and is adapted to the region in which it is planted; and a description of the planting technique and required maintenance activities. The vegetative cover must be capable of survival and growth without extensive maintenance. In addition, any crop must comply with the food-chain restrictions contained in 40 CFR $\$ 264.276$ and 265.276 (see Section 4.4.2.5 for a discussion of these restrictions).

Additional guidance on final covers can be found in 'Permit Applicants' Guidance Manual for Hazardous Waste Land Treatment, Storage, and Disposal Facilities, Final Draft, May 1984, EPA-530-SW-84-004 or "Covers on Hazardous Waste Landfills and Surface Impoundments, Technical Guidance Document, July 1989, EPA-530-SW-89-047.

Soils Removal. The owner or operator may decide to address the closure objectives by removing all contaminated soils. The soil should be removed in layers and sampling conducted following removal of each layer. This procedure will help minimize the amount of soil removed. Excavation should be completed as quickly as possible to reduce the probability of rain transporting contaminants through the unsaturated zone.

After closure procedures are complete, the owner or operator of the facility may have either an independent qualified soil scientist or a registered professional engineer certify that the closure occurred in accordance with the approved guidelines in the closure plan. 


\subsubsection{Conducting Post-Closure Care}

During the post-closure care period, owners or operators of permitted land treatment facilities must continue all activities required during the closure period until the level of hazardous constituents in the treatment zone no longer exceeds the background value of the constituents by a statistically significant amount. $40 \mathrm{CFR} \$ 264.280$ (d)(3) states that in determining whether a statistically significant increase has occurred, the owner or operator must compare existing constituent levels with background levels using statistical techniques that provide "reasonable confidence" that the presence of such constituents will be identified.

The statistical procedure must be appropriate for the distribution of data used to establish background values and provide a balance between failing to detect an existing hazardous constituent and falsely detecting such a constituent when it is not present. The preamble to the July 26,1982 , Federal Register states that the Student's t-test protocol described in $40 \mathrm{CFR} \$ 264.97(\mathrm{~h})$ should satisfy the reasonable confidence criteria if the number of constituents is small.

If the owner or operator of a permitted land treatment facility cannot gain an exemption from postclosure care requirements using the methods outlined above, he must continue all of the activities required during the closure period. The only exception is that soil pore liquid monitoring can be terminated 90 days after the last application of waste into the treatment zone, because the constituents detected by the soil pore monitoring system are fast-moving and should migrate out of the treatment zone soon after waste application.

In addition to the general post-closure care requirements contained in $40 \mathrm{CFR} \$ 265.117$, the owner or operator must do the following:

- Continue unsaturated zone monitoring;

- Control wind dispersal; and

- Comply with food-chain crop restrictions (see below).

\subsubsection{Food-Chain Crop Restrictions}

Following closure, food-chain crops may not be grown in or on the treatment zone in order to prevent the migration of hazardous constituents from the treatment zone into crops and animals, thereby jeopardizing human health. The Regional Administrator may only grant an exemption from these requirements if the owner or operator of the facility can demonstrate that hazardous constituents, other than cadmium:

- Will not be transferred to the food crops by plant uptake or contact, nor will be ingested by food-chain animals; and

- Will not occur in greater concentrations than in or on the same crops in untreated soil in the same region.

If cadmium is present in the wastes applied to the treatment zone, the owner or operator of the facility must maintain the $\mathrm{pH}$ level so as to prevent the cadmium from going into solution. The technical requirements for food-chain prohibitions for cadmium in land treatment facilities can be found in $40 \mathrm{CFR}$ $\$ 264.276$. 


\subsubsection{Additional RCRA Requirements to Consider}

In addition to the unit-specific closure requirements discussed in this section, the owner or operator should also be aware of the following additional RCRA requirements.

- Corrective Action. Corrective action at facilities handling mixed waste may be required as a part of, or concurrently with, closure activities. See Section 2.1.3.2 for a discussion of corrective action requirements.

- Land Disposal Restrictions (LDRs). LDRs prohibit the land disposal of RCRA hazardous wastes beyond certain statutory dates established by Congress in HSWA Restricted hazardous wastes and contaminated soils removed at closure are subject to LDRs. See Section 2.1.4 for a discussion of the LDR program.

- Delisting. If the owner or operator of a facility is able to delist the hazardous component of a mixed waste at closure, the waste is no longer subject to the requirements under RCRA. The delisted material becomes a radioactive waste regulated solely by the DOE. However, delisting a waste does not necessarily exempt the facility that handled the waste from RCRA closure requirements. See Section 2.1.2.5 for a discussion of delisting petitions. 


\section{REFERENCES: SECTION 4.4}

EPA/530-SW-84-004, "Permit Applicants' Guidance Manual for Hazardous Waste land Treatment, Storage, and Disposal Facilities," Final Draft, May 1984.

EPA/530-SW-84-015, "Permit Guidance Manual on Hazardous Waste Land Treatment Demonstrations," Final Draft, July 1986.

EPA/530-SW-89-047, "Technical Guidance Document: Final Covers on Hazardous Waste Landfills and Suriace Impoundments," July 1989.

OSWER Policy Directive \#9476.00-5, "Draft RCRA Guidance Manual for Subpart G Closure and Post-closure Care Standards and Subpart H Cost Estimating Requirements," U.S. EPA, January 1987. 



\section{CONTAINER STORAGE AREAS}

This section presents the requirements for closure of hazardous and radioactive mixed waste container storage areas located at DOE facilities. A container is defined in 40 CFR $\$ 260.10$ as any portable device in which a material is stored, transported, treated, disposed of, or otherwise handled. Examples of containers include 55-gallon drums or barrels. Closure of a container storage area does not refer to closure of the individual containers, but rather to closure of the entire area in which the containers are stored.

Facilities that store hazardous or mixed wastes for greater than 90 days must store these hazardous wastes in container storage areas that meet the design requirements of $40 \mathrm{CFR} \$ 264.175$. Facilities that store hazardous wastes in containers for 90 days or less (beginning the first day waste is accumulated) are only subject to 40 CFR \$\$265.111 and 265.114, which address closure performance standards and decontamination activities respectively.

\subsubsection{What are the Closure Requirements for Container Storage Areas?}

Exhibit 4.5-1 provides an overview of the key closure requirements for container storage areas and references to where in this section more detailed information is provided.

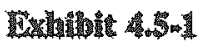

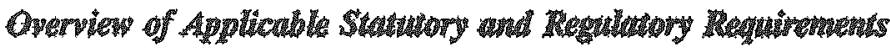

All hazardous waste and residues, and at containers, mimers, bases, and soils contaminated win hazardous wastes must be removed or decontaminated.

Section 4.5 .2

Because all wastes and conainers must be temoved at chostre there are no postclosure care requirements.

Section 4.5 .2

\subsubsection{Statutory Requirements}

RCRA contains no specific requirements applicable to closure of container storage areas.

\subsubsection{Regulatory Requirements}

The regulatory requirements for container storage areas at both interim status and permitted facilities have remained unchanged since 1981. When the Subpart I regulations were promulgated on May 19, 1980, no specific closure standards were promulgated for permitted or interim status container storage facilities. In 1981 (46 FR 2831), EPA stated that the closure requirements found in Part 265, Subpart G, were applicable 
to interim status container storage facilities, but for purposes of clarification and to be consistent with the existing closure requirements of tanks (Subpart J), the Agency promulgated a closure standard applicable to permitted container storage areas in Part 264. EPA has not incorporated the same specific requirements in Part 265 as of June 1990.

\subsubsection{Closure of Conkcuiner Storage Areas}

The technical closure requirements pertaining to containers are found in 40 CFR $\$ 264.178$. These requirements only allow for the clean closure of container storage areas. The Subpart $G$ procedural requirements for closure of these units are discussed in Chapter 3 of this manual. Exhibit 4.5-2 outlines closure requirements for container storage areas.

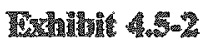

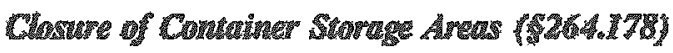

Al closure, owners or operaton of all facilities that store containers of hazarcous waste mus comply with the following requineruents.

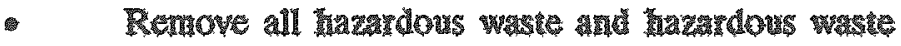
trsidues from the containment ared.

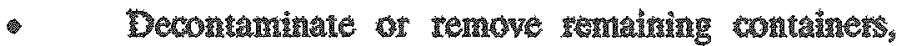
bases, and soil contaminated with hazardous watsto or hazardons waste residues.

- At closure, the owher or operator becomes generator of Mazardous viste and must manage the waste accordingly, unless he can demonstrate in accordance with $261.3(0)$ that the waste renoved from the containment area is not a hazarous waste.

The following sections provide an overview of required closure activities applicable to owners or operators of container storage areas:

- Prepare closure plan (Section 4.5.2.1);

- Conduct closure (i.e., remove or decontaminate all wastes, equipment, etc.)

(Section 4.5.2.2); and

- Demonstrate clean closure (Section 4.5.2.3). 


\subsubsection{Preparing Closure Plass for Container Storage Areas}

All container storage areas must have a written closure plan as described in Chapter 3 of this manual. The closure plan must identify the steps necessary to perform closure of the container storage area at any time during its active life. Exhibit 4.5-3 presents a sample outline of a closure plan for a container storage area. For additional guidance see OSWER Policy Directive \#9476.00-5, "RCRA (Resource Conservation and Recovery Act) Guidance Manual for Subpart G Closure and Post-Closure Care Standards and Subpart H Cost Estimating Requirements."

\subsubsection{Implementing Closure container Storage Areas}

In order to properly clean close a container area, hazardous wastes and residues must be removed, and contaminated containment system components (e.g., bases, structures, and equipment), soils, and subsoils, ${ }^{27}$ must be either removed or decontaminated. See Section 4.2 .3 of this manual which provides an overview of the key activities required for clean closure.

With one exception (see discussion regarding "empty" containers below), all removed containers, liners, bases, and other materials must be managed as hazardous waste unless the wastes have been delisted in accordance with 40 CFR $\$ \$ 260.20$ and 260.22 , or the wastes do not exhibit any hazardous waste characteristics (see Section 2.1.2 of this manual for a discussion of hazarcous waste characteristics). In addition, if these materials are mixed wastes, they must be managed in accordance with DOE 5280.2A, Radioactive Waste Management, September 26, 1988. Before disposing of any of the wastes in a landill, injection well, or any other land disposal unit, the owner or operator must determine if the wastes are prohibited from land disposal under the land disposal restrictions (LDRs). If the waste is restricted from land disposal, it must be treated by a method that meets the treatment standards of 40 CFR $\$ \$ 268.40$ to 268.44 .

27 The EPA interprets "soils" to include both unsaturated soils and soils containing ground-water. For this reason, a clean closure must include consideration of potential ground-water contamination under both Parts 264 and 265 (53 FR 8705 and 53 FR 9944). 
Facility Description

Inventory Removal and Decontamination

Security Systems

Closure Certification

Schedule of Closure
- Facility location and size;

- Topographic map;

- List of other hazardous waste management units and wastes handled in each;

- Hydrogeological information;

- Description of container storage area capacity and design;

- Secondary containment systems.

- References to other environmental permits; and

- Anticipated waivers or exemptions.

- Estimates of maximum inventory (e.g. number of drums) to be removed;

- Procedures for removing inventory;

- Procedures for decontamination or disposal of pads, pallets, containment systems and contaminated subsoils;

- General description.

- Activities to be conducted and

- Documentation.

- Expected year of closure (only for interim status facilities without approved closure plans);

- Time required for waste removal, facility decontamination, and final closure; and

- Support for deadline extensions, if applicable.

Source: OSWER Policy Directive No. 9476.00-5, "RCRA Guidance Manual for Subpart G Closure and PostClosure Care Standards and Subpart H Cost Estimating Requirements (Draft)". 
Exhibit 4.5-4 is an overview of the key activities for implementing closure at container storage areas. More detailed information on each of these activities immediately follows.

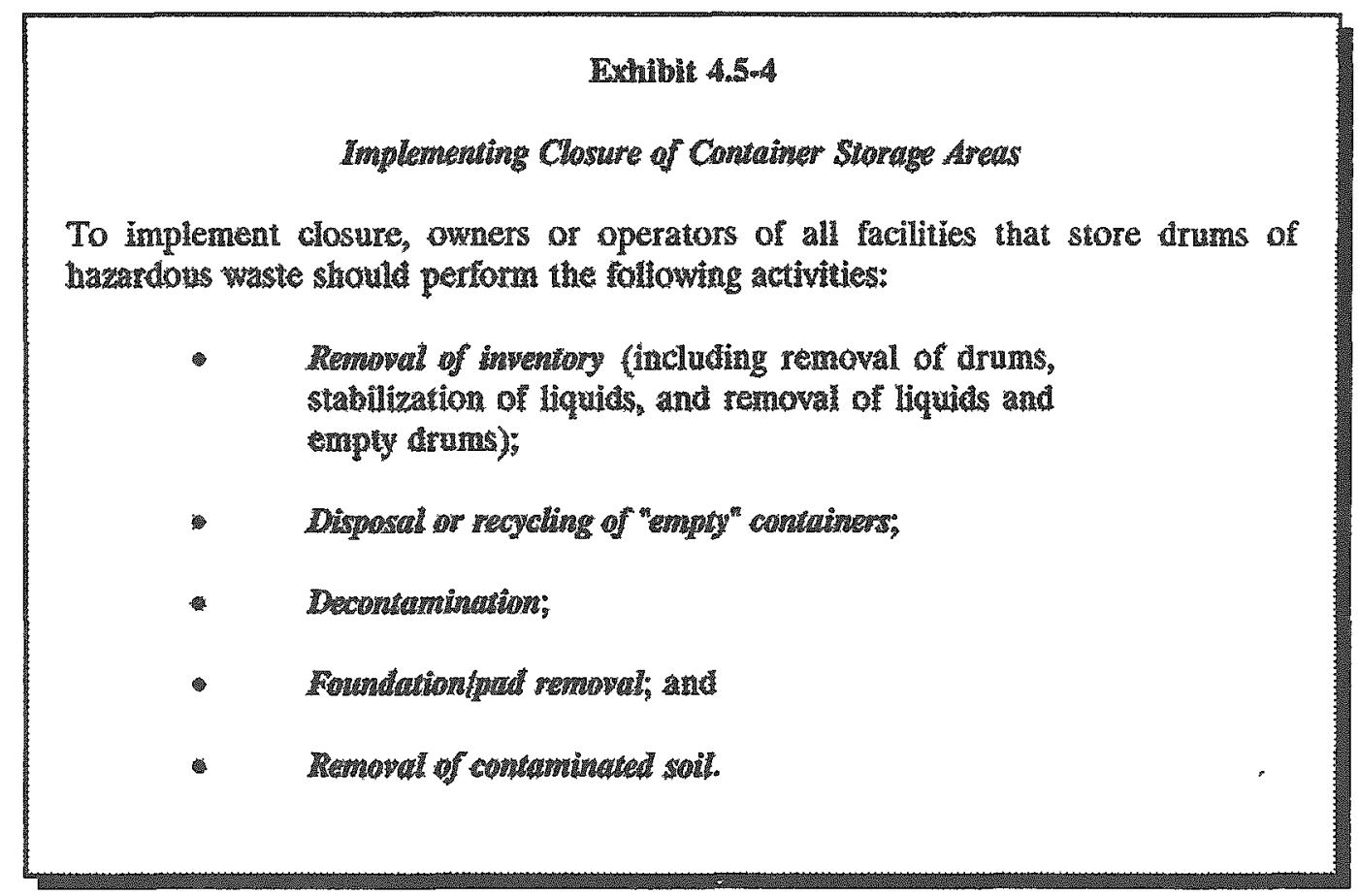

Inventory Mumegement. Closure of container storage areas generally involves sending all drums and their contents off-site. In some cases, however, the owner or operator may empty the drums, stabilize the waste and handle it separately from the drums. Usually the drums are then reused or recycled.

Leaking containers, along with their remaining contents, are usually placed and enclosed within an 85-gallon salvage drum, instead of placing the remaining contents of the leaking container into a new drum. To perform this operation, leaking containers are usually hoisted, making use of a drum lifter, and placed into the salvage drum, which in turn is then sealed and loaded into a truck for transportation to a treatment, storage, and/or disposal area. If free liquids remain in containers to be landfilled, they must first be solidified. In this pretreatment method, an absorbent material is added to the containerized wastes. Any spills generated during the container removal process must be cleaned up and managed as hazardous waste.

Disposing or Recycling of "Empty" Contrimers. According to 40 CFR \$261.7 and $\$ 261.33$ (c), if a hazardous waste, except a waste that is a compressed gas or identified as an acutely hazardous waste in $40 \mathrm{CFR}$ $\$ \$ 261.31,261.32$, or $261.33(\mathrm{e})$, is emptied from a container, the residue remaining in the container is not considered a hazardous waste and is thus not subject to Subtitle $C$ regulations if the following conditions hold:

- All wastes have been removed using such practices as pouring, pumping, aspirating, etc.; and

- No more than 2.5 centimeters of residue remain on the bottom of the container or inner liner; or 
No more than three percent by weight of the total capacity of the container remains in the container or inner liner if the container is less than or equal to 110 gallons in size; or

- No more than 0.3 percent by weight of the total capacity of the container remains in the container or inner liner if the container is greater than 110 gallons in size.

A container that held a hazardous waste in the form of a compressed gas is considered empty when the pressure in the container approaches atmospheric.

A container that held an acutely hazardous waste is considered empty if one of the following conditions hold:

- The container or inner liner has been triple rinsed; or

- The container or inner liner has been cleaned by another method shown by scientific literature or tests conducted by the generator, to achieve equivalent removal; or

- The inner liner of the container that prevented contact of the hazardous waste with the container has been removed.

Decontuminotion. In the case of sumps, other collecting areas within the containment system, and underlying bases (or pads), owners and operators may wish to pursue options involving steam cleaning, highpressure washing, or sandblasting. In general, facility structures and equipment must be repeatedly cleaned, washed, or rinsed, until monitoring samples of the last rinse water satisfy the closure performance standards set for a site. Residuals resulting from this activity are assumed to be treated as hazardous wastes. The regulations also require owners or operators to decontaminate all contaminated equipment, tools, clothing, supplies, etc., involved in operating, maintaining, and closing the unit. Guidance on procedures for equipment decontamination are provided in EPA/600/2-85/028, "Guide for Decontaminating Buildings, Struchures, and Equipment at Superfund Sites," 1985.

Foundation/Pal Removel. If bases and other container system structures or equipment cannot be decontaminated, they must be removed. Demolition equipment required may include a backhoe loader with a hydraulic hammer or hand-held equipment such as a jack hammer. Other equipment required may include a ruck, and either a hydraulic backhoe, front shovel, or a dozer coupled with a front-end loader. To prevent the generation of dust during waste removal, water sprays should be used. The selection of equipment is again dependent on the waste materials; however, further guidance on the selection of removal equipment is provided in Section 7.1 of EPA/625/6-85/006, "Handbook on Remedial Actions at Waste Disposal Sites," October 1985.

Soils Rerwoval. Soils underlying the container storage area should be tested at this point to determine the extent of contamination. Any soils which have been determined to contain contaminants in excess of the exposure limits specified in the closure plan must be removed. The soil should be removed in layers and sampling conducted following removal of each layer. This procedure will help minimize the amount of soil removed. Excavalion should be completed as quickly as possible to reduce the probability of rain transporting contaminants through the unsaturated zone. 


\subsubsection{Demonstruting Clean Closure}

An independent registered professional engineer and the owner or operator must certify that closure has been conducted in accordance with the approved closure plan. Supporting documentation of the certification must be made available to the Regional Administrator upon request.

\subsubsection{Addicional RCRA Requirements to Consider}

In addition to the unit-specific closure requirements discussed in this section, the owner or operator should also be aware of the following additional $R C R A$ requirements.

- Corrective Action. Corrective action at facilities handling mixed waste may be required as a part of, or concurrently with, closure activities. See Section 2.1.3.2 for a discussion of corrective action requirements.

- Land Disposal Restrictions (LDRs). LDRs prohibit the land disposal of RCRA hazardous wastes beyond certain statutory dates established by Congress in HSWA. Restricted hazardous wastes and contaminated soils removed at closure are subject to LDRs. See Section 2.1.4 for a discussion of the LDR program.

- Delistimg. If the owner or operator of a facility is able to delist the hazardous component of a mixed waste at closure, the waste is no longer subject to the requirements under RCRA. The delisted material becomes a radioactive waste regulated solely by the DOE. However, delisting a waste does not necessarily exempt the facility that bandled the waste from RCRA closure requirements. See Section 2.1 .2 .5 for a discussion of delisting petitions. 
DOE 5820.2A, "Radioactive Waste Management," September 26, 1988.

EPA/580-SW-87-010, "RCRA Guidance Manual for Subpart G Closure and Post-closure Care Standards and Subpart H Cost Estimating Requirements," January 1987.

EPA/SW-873, ".Closure of Hazardous Waste Surface Impoundments," 1982.

EPA/600/2-85-028, "Guide for Decontaminating Buildings, Structures, and Equipment at Superfund Sites," 1985.

EPA/625/6-85-006, "Handbook: Remedial Action at Waste Disposal Sites (Revised)," October 1985.

OSWER Policy Directive \#9476.00-5, "Draft RCRA Guidance Manual for Subpart G Closure and Post-closure Care Standards and Subpart H Cost Estimating Requirements," U.S. EPA, January 1987.

OSWER Policy Directive \#9476.00-6, "Final Report/Guidance Manual: Cost Estimates for Closure and Postclosure Plans (Subparts G and H) Volume III - Unit Costs, "November 1987; and "Volume I - Treatment and Storage Facilities." 
This section presents the requirements for closure and post-closure care of tank systems containing hazardous and mixed wastes located at DOE facilities. A tank system includes a hazardous waste storage or treatment tank and its ancillary equipment and secondary containment system. Ancillary equipment means any device including, but not limited to, piping, fittings, flanges, valves, and pumps used to distribute, meter, or control the flow of hazardous waste from: 1) its point of generation to a storage or treatment tank $(\mathrm{s}), 2)$ between hazardous waste storage or treatment tanks to a point of disposal on-site, or 3) to a point of shipment for disposal off-site (40 CFR 260.10). In general, there are three types of tank systems: onground (aboveground) and underground tanks typically made of steel or fiberglass, and inground tanks usually constructed of concrete. A tank must be self-supporting when not surrounded by earthen materials; if it is not, it is a surface impoundment.

The following types of tanks are exempted from RCRA (see 40 CFR \$260.10):

- Elementary neutralization umits -- devices which: (1) are used for neutralizing wastes which are hazardous wastes only because they exhibit the corrosivity characteristic defined in 40 CFR \$261.22, or are listed in Subpart D of Part 261 for this reason; and (2) meet the definition of tank in $\$ 260.10$.

- Wastewater treatment units -- devices which: (1) are part of a wastewater treatment facility which is subject to regulation under Section 402 or Section 307 (b) of the Clean Water Act; (2) receives and treats or stores an influent wastewater which is a hazardous waste as defined in $40 \mathrm{CFR} \$ 261.3$, or treats or stores a wastewater treatment sludge which is a hazardous waste as defined in $\$ 261.3$; and (3) meets the definition of tank in $\$ 260.10$.

\subsubsection{What are the Closture Requirements for Tank Systems?}

This section briefly describes the statutory authorities and regulations pertinent to the closure of tank systems. Exhibit 4.6-1 presents the key closure requirements for tank systems and references to where in this section more detailed information is provided.

\subsubsection{Statutory Requirements}

RCRA does not contain any closure requirements specific to hazardous waste tanks, but does provide for minimum design, operating, and permitting requirements. HSWA added two new provisions affecting the regulation of hazardous waste tanks:

- Leak detection requirements of all new underground hazardous waste tank systems (Section 3004(0)(4)); and

- Technical and permitting standards for underground tanks that cannot be entered for inspection (Section 3004(w)). 


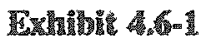

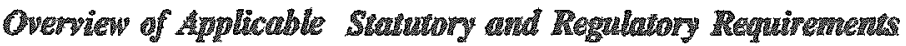

At closure, the owner or operator must remove of cecontaminate the tank, its ancillary equipment, and any existimg secontary conkahment system.

Secrion $4.6,2$

All contaminated souls and ground water must be renowed at closwe bness the owner or operator demonstrates to EPA tha his is inarracticable.

Sections 4.62 .2 and 4.62 .5

Owners and operators of tan systerns that do not have secondary contanument and are not exempt from the secondary containment requirements mst prepar a contingent closure and a post-closure plat describing closure as a landtatu.

Section 4.6 .22

if an contaminated soils or gromad water camol be practicably temoned or

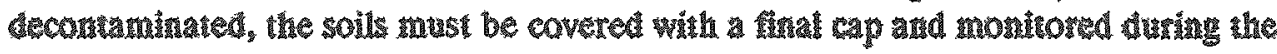
post + closure care period.

Sections 4.6 .25 and 4.6 .26

Prior to HSWA, RCRA did not address underground tanks that cannot be entered for inspection. In Section 3004(w), Congress mandated EPA to regulate these RCRA tanks to at least as stringent a degree as petroleum USTs regulated under HSWA $\$ 9003$. As described below, when EPA revised the hazardous waste tank regulations on July 14,1986 , it extended all design and operating requirements to these underground hazardous waste tanks.

\subsubsection{Regulatory Requirements}

Regulatory requirements for interim status and permitted tank systems are found in 40 CFR Parts 264 and 265, Subpart J, respectively (revised most recently on July 14, 1986 (51 FR 25422)). These rules establish technical standards and operating procedures for the owners and operators of permitted, interim status, 90-day accumulation, and small quantity generator tank systems. ${ }^{28}$

Prior to the July 14, 1986, regulations, the closure requirements for tanks only required that all hazardous wastes and hazardous waste residues be removed from tanks, discharge control equipment, and discharge confinement structures (51 FR 25456). However, in the 1986 final rule, EPA substantially changed the closure and post-closure requirements of Subpart J (\$\$264.197 and 265.197 ) by requiring owners and operators who must leave contaminated soils in place at closure to install ground-water monitoring systems, close their tank systems as landfills, and conduct post-closure care, including ground-water monitoring. It also

28 "Small quantity generators" refer to generators of 100 to $1,000 \mathrm{~kg} /$ month of hazardous waste. 
added provisions requiring certain tank systems to prepare contingent closure and post-closure care plans. Finally, it also extended the revised design and operating standards for hazardous waste tanks to underground waste tanks that cannot be entered for inspection, which were exempted.from regulation under the previous standards.

Tank systems found to be leaking or unfit for use must be closed unless the owner or operator can demonstrate that the cause of the leak was a spill that has not damaged the integrity of the tank system, or that the tank system can be repaired to prevent additional leaks (\$\$ 264.196(e) and 265.196(e)). In the case of a tank system that requires repair, if the leak from the tank system occurred from a component that did not have secondary containment, then the owner or operator must provide that component with secondary containment, as required under \$264.193, before it is retumed to service. However, if the leall occurred from an aboveground portion of the tank system that can be inspected visually, the tank system can be returned to service without secondary containment if the repair is extensive. Additionally, any extensive repairs conducted on a tank system must be certified and any replacement equipment used in such repairs must satisfy the requirements for new equipment. If any of the preceding requirements cannot be met, the tank system must be closed.

\subsubsection{Clasure of Tasale Systems}

Closure requirements for tanks are found in 40 CFR \$\$264.197 and 265.197 and are equivalent for permitted and interim status facilities. Specifically, all waste residues, containment system components, liners, contaminated soils, and equipment and structures contaminated with waste must be decontaminated or removed. These components must then be managed as hazardous waste unless specifically exempted under 40 CFR 261.3(d) (i.e., unless it can be dernonstrated that they do not exhibit hazardous waste characteristics, or have been delisted). If the owner of operator finds that removal of all contaminated soils (i.e., unsaturated and saturated soils, including ground water) is not practicable, then the unit must be closed as a landinl.

The following is an overview of the required closure activities for owners or operators of tank systems:

- Prepare closure plan (Section 4.6.2.1);

- Prepare contingent closure and post-closure plans for units without secondary containment (Section 4.6.2.2)

- Conduct closure (Section 4.6.2.3); and

- Demonstrate clean closure (Section 4.6.2.4); or

- If clean closure is demonstrared to be impracticable, submit revised closure/post-closure plans, close as a landrill. (Section 4.6.2.5); and

- Conduct post-closure care and monitoring (Section 4.6.2.6)

The following sections provide more specific guidance on how to properly perform each of these activities. 


\subsubsection{Preparing a Tank Closure Plan}

All tank systems must have a written closure plan as described in Chapter 3 of this manual. The closure plan must identify the steps necessary to perform closure of the tank system at any time during its active life. Exhibit 4.6-2 presents a summary of the information requirements specific to the clean closure of tank systems that should be included in a closure plan.

\subsubsection{Preparing Contingent Plans for Facilities without Secondary Containment}

Owners and operators of permitted and interim status tank systems that do not have secondary containment and are not exempt from the secondary containment requirements (see \$264.190 and \$265.190, and \$264.193 and \$265.193) must prepare a contingent closure plan and a contingent post-closure plan, in addition to the closure plan for closing as a storage unit $\left(\$ 264.197(\mathrm{c})\right.$ and $\$ 265.197(\mathrm{c})$ ). ${ }^{29}$ The contingent closure and post-closure plans are required even if the owner or operator is planning to install secondary containment in the future. In such a case, the plans would be required until appropriate secondary containment is installed. Exhibits $4.6-3$ and $4.6-4$ present sample outlines for contingent closure and contingent post-closure care plans for owners or operators of tank systems. The contingent closure plan would supplement the clean closure plan and would be implemented if clean closure is not possible. $A$ key component of these plans includes the descriptions of a 40 CFR Part 264, Subpart F ground-water monitoring system as required for tank systems that close with contaminated soils in place.

\subsubsection{Implementing Closure of Storage aud Treatment Tank Systems}

The owner or operator must remove or decontaminate all waste residues, contaminated system components (i.e., secondary containment liner or vaults), contaminated soil, and structures contaminated with hazardous waste. The decontamination requirement also applies explicitly to all soils at a facility, including saturated soils and ground water. If the owner or operator demonstrates that not all contaminated soils can be practicably removed or decontaminated at closure, then the owner or operator must close the tank system and perform post-closure care in accordance with the requirements applying to landfills (see Sections 4.6 .2 .5 and 4.6.2.6).

All removed materials must be managed as hazardous waste unless the facility has received EPA approval to delist the wastes (specified in 40 CFR 261.3(d); also discussed in Section 2.1.2.5 of this manual). In addition, if these materials are mixed radioactive wastes, they must be managed in accordance with $D O E$ 5280.2A, Radioactive Waste Management, September 26, 1988. Finally, if these wastes are prohibited from land disposal under the land disposal restrictions (LDRs), they must be treated by a method that meets the treatment standards of $40 \mathrm{CFR} 268.40$ to 268.44. The LDR program is discussed in detail in Section 2.1.4.

29 For a description of tank technologies, operating practices, location characteristics, or combinations of environmental conditions and waste characteristics that may allow for a variance from the secondary containment requirements see: "Technical Resource Document for Obtaining Variances from Secondary Containment Requirements for Hazardous Waste Tank System: Volume I-Technology-Based Variance" or "Volume 2 - Risk-Based Variance" of the same title. 
Exhibit 4.6-2

TANK CLOSURE PLAN SAMPLE OUTLINE

Section

Wlements

\section{Freility Conditions}

Inventory Removal and Decontamination
- Facility location and size;

- List of other hazardous waste management units and wastes handled in each;

- Hydrogeological information;

- Tank system description (volume, size, type of liner system, etc.);

- Description of past releases and corrective measures taken;

- References to other environmental permits; and

- Anticipated waivers or exemptions.

- Estimates of inventory to be removed;

- Procedures for removing all waste inventory from the tank systems and procedures for removing or decontaminating all tank system components (e.g., steam cleaning);

- Procedures for removing or decontaminating all secondary containment structures and contaminated soils or additional equipment at the site (e.g., demolition of pad, dismantling tank);

- Procedures for decontamination/disposal of equipment and disposal of residuals and contaminated washwaters; and

- Major radionuclides and their concentrations.

- Listing of exposure limits for Appendix VIII constituents;

- Background levels at the site; and

- Description of the testing to determine if pad, piping, containment areas, etc. 
Exhibibir 4.6-2 (Contimued)

TANK CLOSURE PLAN SAMPLE OUTLINE

\begin{tabular}{ll}
\hline \multicolumn{1}{c|}{ Section } & \multicolumn{1}{c}{ Elements } \\
Security Systems & General description. \\
Closure Certification & $\begin{array}{l}\text { Activities, tests to be conducted; and } \\
\text { Documentation. }\end{array}$ \\
Schedule of Closure & $\begin{array}{l}\text { Expected year of facility closure (only for } \\
\text { interim status facilities without approved } \\
\text { closure plans; } \\
\text { Time required for waste treatment, } \\
\text { removal, decontamination, and final } \\
\text { closure; and } \\
\text { Support for deadline extensions, if } \\
\text { applicable. }\end{array}$ \\
\hline
\end{tabular}

Source: OSWER Policy Directive No. 9476.065, "RCRA Criteria Manual For Subpart G Closure and PostClosure Carte Standards and Subpart H Cost Estimating Requirements (Draft)" 
Exhibit 4.6-3

TANK CONTINGENT CLOSURE PLAN SAMPLE OUTLINE

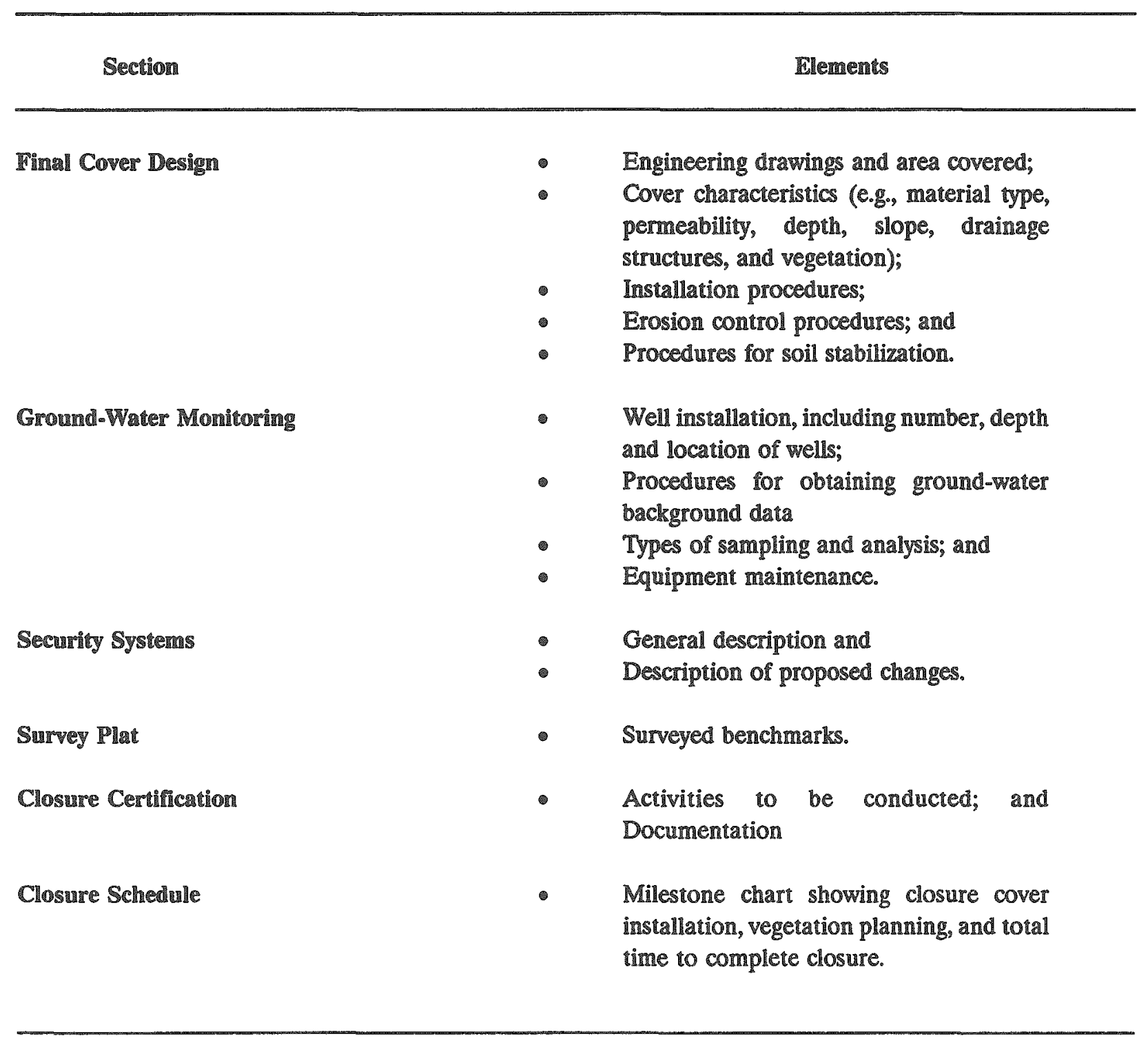

Source: OSWER Policy Directive No. 9476.00-5, "RCRA Guidance Manual for Subpart G Closure and PostClosure Care Standards and Subpart H Cost Estimating Requirements (Draft)". 
Exhibit 4.6-4

TANK CONTINGENT POST-CLOSURE PLAN SAMPLE OUTLINE

\begin{tabular}{|c|c|}
\hline Section & Elements \\
\hline Ground-Water Monitoringg & $\begin{array}{l}\text { Number, location, and depth of } \\
\text { wells; } \\
\text { Frequency of sampling; and } \\
\text { Types and procedures for } \\
\text { analyses. }\end{array}$ \\
\hline Soil Monitoring & $\begin{array}{l}\text { Number and frequency of samples; } \\
\text { Sampling procedures; and } \\
\text { Types of analyses conducted. }\end{array}$ \\
\hline Inspections & $\begin{array}{l}\text { Frequency and } \\
\text { Scope. }\end{array}$ \\
\hline Maintenance Activities & $\begin{array}{l}\text { Final cover; } \\
\text { Monitoring systems; and } \\
\text { Security systems. }\end{array}$ \\
\hline
\end{tabular}

Source: OSWER Policy Directive No. 9476.00-5, "RCRA Guidance Manual for Subpart G Closure and PostClosure Care Standards and Subpart $H$ Cost Estimating Requirements (Draft)" 
To implement closure of storage and treatment tank systems, the owner or operator must either remove the tank system, or decontaminate it and leave it in place. Regardless of which option is chosen, the facility must either remove contaminated soils, or demonsstrate to EPA that it is impracticable to do so. The following subsections describe the general activities required for removing tank systems, leaving tank systems in place, and excavating contaminated soils and ground water.

\subsection{Removing Tank Systems}

Tanks are usually removed under the following circumstances: 1) the secondary containment system is contaminated, 2) it is necessary to remove contaminated soils or subsoils, or 3) the tank area surrounding onground or aboveground tanks is closed as a landfill. Actions involved in removing tank systems at closure generally include liquid removal, containerization of bulk waste and removal of the containers, tank cleaning, tank removal, excavation of vault systems, base or pad removal, liner removal, soils removal, and excavation of contaminated soils and containments systems. A description of each is provided below.

Waste Removal The first step in closing tanks involves removing bulk wastes from the tank system. First, liquid wastes and sludges should be pumped from the tank into drums or trucks for transport to storage or to the site of actual treatment or disposal. Waste removal can only be undertaken after the characteristics of the waste have been fully determined. In particular, the hazards posed by radioactive mixed wastes stored in tanks may necessitate significantly more stringent worker safety precautions during closure. These precautions are not covered in this guidance document, but should be consulted before undertaking closure activities.

The type of pump chosen for the operation is dependent on the physical and chemical characteristics of the waste. For example, viscous or oily solvent wastes generally require the use of a rotary lobe pump made of cast iron; aqueous wastes require the use of a cast iron centrifugal pump; and siudges containing heavy metals and having solids content between 1 percent and 5 percent require the use of a stainless steel centrifugal pump. Pump size is primarily a function of the time allowed for closure and the quantity of material to be removed.

Waste Treatment or Disposal. After removing the bulk wastes from the tank system, they must be treated, stored further, or disposed. In particular, restricted wastes must be treated to BDAT levels as required by the LDR program. It will be critical to determine the waste characteristics and identities in order to ensure compliance with these treatment standards. Chapter 2 outlines the LDR requirements for hazardous and radioactive mixed wastes.

Decontamination. Decontamination is a critical task, especially when permanently closing a tank system. Decontamination involves removing all remaining wastes, sludges, and waste residues from the tank system. The following guidance is found in OSWER Policy Directive No. 9483.00-1, "Technical Resource Document for the Storage and Treatment of Hazardous Waste in Tank Systems, "December 1986, EPA/530-SW-86044. For further information on tank decontamination see: (API) Publication 2015, "Cleaning Petroleum Storage Tanks," (September 1985); API Publication 2015A, "A Guide for Controlling the Lead Hazard Associated with Tank Entry and Cleaning (Supplement to API RP 2015); and NFPA No. 327, "Standard Procedures for Cleaning or Safeguarding Small Tanks and Containers," (1982). 
- Cleaning operations should be performed under the supervision of those who understand the hazardous potential of the stored waste;

- Personnel must be sufficiently trained and equipped to perform decontamination safely;

- Testing should be done to ensure complete decontamination;

- Sludges and residues should be removed from the area near the tank using explosion-proof equipment (i.e., vacuum pumps and other respiratory and safety equipment);

- All hazardous wastes removed from the tank system must be managed in a Subtitle C hazardous waste treatment, storage, and disposal unit;

- Stubborn residues should be removed by pressure hosing with water, steam cleaning, or solvent washes; and

- Residues from cleanup chemicals such as mineral spirits and kerosene should be treated or disposed of properly.

Owners and operators should pursue options involving steam cleaning, high-pressure washing, or sandblasting to decontaminate tank interiors, the interstitial space between double-walled steel tanks, vault system interiors, sumps, troughs, or other collecting areas within the containment system, and underlying bases (concrete or asphalt slabs).

In general, facility structures and equipment must be repeatedly cleaned, washed, or rinsed, until monitoring samples of the last rinse water satisfy the closure performance standards set for a site. Residuals resulting from this activity are assumed to be treated as hazardous wastes. The regulations also require owners or operators to decontaminate all contaminated equipment, tools, clothing, supplies, etc., involved in operating, maintaining, and closing the unit. Thus, decontamination generally occurs throughout the entire cleanup process until final closure is approved by EPA. Guidance on procedures for equipment decontamination are provided in EPA/60012-85/028, "Guide for Decontaminating Buildings, Structures, and Equipment at Superfund Sites," 1985. If bases, liners, and other container system structures or equipment cannot be decontaminated, they must be demolished and disposed in a Subtitle $C$ disposal unit. Exhibit 4.6-5 summarizes decontamination methods for tanks and other facility structures. 


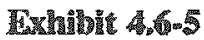

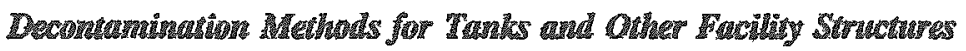

- Steamelemaing - An average of 50 square Teet of surface arez is cleaned per hour. Residual is generated at a rate of approximately ronsr gallons per sąure foot.

- High-1ressure Washing - An average of 10 square fee of surface

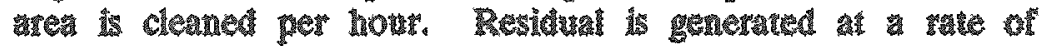
approximatety lour grathons per square look

- Sandblastha (dry system) - An average of 50 gąure foet of surface ares is cleaned per hour. Residuat is generated at at ate of appromately wounds per square font.

Tark Removel. After performing the steps above, general procedures to be followed in removing tanks include the following:

- Disconnect and cap all fill, gauge, and vent lines;

- Temporarily plug all tank openings, except for a 1/8-inch hole for venting;

- Free the tank of all flammable or toxic vapors;

- In the case of underground storage tanis, remove the tank from the ground;

- Thoroughly clean the outside of the tank;

- Render the tank unfit-for-further use by puncturing holes in the walls of the tank;

- Dismantle the tank (from the outside to limit worker exposure hazards) if necessary; and

- Transport the tank from the site.

Soil excavation equipment is required in the case of underground tanks covered with soil. In removing underground tanks, a crane is used and in some cases, the tank must be detached from its supports before lifing. If the underground tank is anchored 10 a "deadman" or concrete slab, the anchor should be tested to see if it is contaminated with wastes. If not contaminated, it may be left in place. If the anchor slab is contaminated, demolition and excavation equipment will be necessary for removal. Removed fiberglassreinforced plastic tanks may be reused provided that a thorough inspection is made by an approved agent of 
the tank manufacturer and the manufacturer certifies that the tank is acceptable for reuse. If a removed tank will not be reused, it must be rendered unfit for further use by puncturing holes in the walls of the tank and dismantling the tank if necessary.

Since inground tanks may be constructed of concrete, a jackhammer and/or a hydraulic hammer attached to a backhoe is needed to demolish the structure. A truck will also be necessary to remove the rubble. Large field erected steel tanks are loosened from concrete pads using a jackhammer or cut from steel supports using a cutting torch, and set aside with a crane. In the case of onground/aboveground tanks greater than 700 square feet in surface area, the tank may have to be cut into pieces using a cutting torch and placed aside using a crane. Other procedures and information on the removal and disposal of tanks can be found in the following references:

- API Publication 2015, "Cleaning Petroleum Storage Tanks," (September 1985):

- API Publication 2015A, "A Guide for Controlling the Lead Hazard Associated with Tank Entry and Cleaning (Supplement to API RP 2015);

- API Publication 2015B, "Cleaning Open-Top and covered Floating-Roof Tanks,"(1981);

- API Publication 1604, Recommended Practice for Abandonment or Removal of Used Underground Service Station Tanks," (1981);

- NFPA No. 30, "Flammable and Combustible Liquids Code," (1984);

- NFPA No. 327, "Standard Procedures for Cleaning or Safeguarding Small Tanks and Containers," (1982); and

- National Institute of Occupational Safety and Health (NIOSH) No. 80-106, "Working in Confined Spaces," (December 1979).

Base or Pad Removal. Demolition equipment that may be required includes a backhoe loader with a hydraulic hammer, or hand-held equipment such as a jack hammer. Other equipment that may be required includes a truck, and either a hydraulic backhoe, front shovel, or a dozer coupled with a front-end loader. A crane or backhoe should be used to remove plastic or semisolid sediments and a bulldozer can be used to break down any solidified materials prior to excavation. To prevent the generation of dust during waste removal, water sprays should be used. The selection of equipment is again dependent on the waste materials; however, further guidance on the selection of removal equipment is provided in Section 7.1 of EPA/625/685/006, "Handbook on Remedial Actions at Waste Disposal Sites," October 1985.

Voult System Removal. Vault systems used as secondary containment for underground storage tanks can be broken making use of a hydraulic hammer attached to a backhoe. Concrete which is demolished below grade can be loaded into a truck using a backhoe. A backhoe or front-end loader can be used to remove small vauli system covers. A crane may be necessary for larger covers. A jackhammer or other demolition equipment may be necessary to loosen covers or break up the cast-in-place covers of concrete tanks prior to tank removal. 
Removal of Secondary Contaimment. Secondary containment structures should be removed following waste removal and before removal of any subsoils to minimize the potential for additional contamination of the subsoil. Normal excavation methods can be used to remove liners made of clay and soil. However, concrete containment systems should first be broken up and then removed.

\subsection{Leaving Decontaminuted Tanks and Vandss in Place}

The abandonment of underground, inground, onground, and aboveground tanks may be a preferred option due to safety and economic reasons. However, some state laws may prohibit the abandonment of tanks. The existence of such requirements should be determined first. The abandonment of underground storage tanks may be done by two procedures: one is a general method, while the other involves sand-pumping. Abandonment procedures for underground storage tanks include the following: ${ }^{30}$

Method for Abandoning Underground Tanks - General

- Drain and flush the piping into the tank and remove all hazardous waste that can be pumped out;

- Dig down to the top of the tank, remove fill drop tube, and disconnect all fill, inlet, and gauge lines (leave vent line open until the tank is filled);

- Cap all the open ends of lines that will no longer be used and fill the tank with water until almost overflowing;

- Remove excess waste floating on top and empty into a container that is appropriate for disposal;

- After water has purged the tank, make several holes into the top of the tank and pump out the water (properly dispose of water);

- Completely fill the tank and any remaining stubs with sand, gravel, or other approved, inert, solid, non-shrinking material;

- Test for complete decontamination, and disconnect and cap the vent line.

Method for Abandoning Underground Tanks - Sand Pumping

- Remove all hazardous waste from the tank and all connecting lines, and test for complete decontamination;

- Cut off vent lines approximately three feet above grade to promote an increased head on sand being pumped into the tank and thus complete

30 OSWER Policy Directive No. 9483.00-1, "Technical Resource Document for the Storage and Treatment of Hazardous Waste in Tank Systems," December 1986. 
filling of the tank (Do mot use cutting torch if ignitable wastes are involved);

- Disconnect and cap extraction (suction) lines, and make the threaded connections between fill lines of the tank and the discharge line from the sand pump liquid-tight (on tanks equipped with fill pipes extending below the top of the tank, remove the extension piping within the tank);

- Attach a drain hose to the end of the vent line using a tight or threaded connection and direc it into a reservoir to hold any residual hazardous waste that might be left in the tank;

- Pump sand into the tank until a dense suspension of sand in water discharges from the vent lines (at this point, caps may be removed from extraction lines for observation and sand should be present here before the pumping is stopped); and

- Observe caution in the vent line area due to the possible emission of flammable or toxic vapors, if necessary conduct vapors to an area which will be more protective to human health and the environment.

A separate procedure is typically used for abandoning inground, onground, and aboveground tanks. It includes the following general steps:

- Remove as much waste as possible from the tank and piping system, disconnect and cap all fill, gauge and vent lines;

- Free the tank of all lammable or toxic vapors;

- Remove all sludge or other tank residves, and thoroughly clean the inside of the tank;

- Test for complete decontamination;

- Take security measures necessary to prevent casual or accidental entry into the tank; and

- Anchor tank to prevent flotation if located in a floodplain by filling if with sand, gravel, or other inert material.

\subsection{Excavation of Contaninated Soils}

After removing or decontaminating the tank system, the owner or operator of a tank facility must attempt to remove all contaminated soils (i.e., unsaturated and saturated) during closure, unless he can demonstrate that it is impracticable to do so. The most common method of excavating suriace soils (as well as other tank system components such as vaults, liners, elc.) is by mechanical means. Excavation of the wastes can be accomplished using a crane (with attachments such as a clam shell bucket), backhoe, or bulldozer. $A$ 
crane or backhoe should be used to remove plastic or semisolid sediments and a bulldozer can be used to break down any solidified materials prior to excavation. To prevent the generation of dust during waste removil, water sprays should be used. The selection of equipment is again dependent on the waste materials; however, detailed guidance on the selection of equipment for sludge removal is provided in Section 7.1 of EPA/625/6-85/006, "Handbook on Remedial Actions at Waste Disposal Sites," October 1985.

EPA has not provided guidance on how to determine the impracticability of excavating contaminated soils. However, helpful guidance may be contained in EPA's "Guidance Manual: Cost Estimates for Closure and Post-Closure Plans (Subparts $G \& H$ ), Volumes I through $N$. In general, EPA is unlikely to approve any request for landfill closure unless there is significant ground-water contamination which cannot be remedied in a timely fashion. In other words, if soils are contaminated and no significant ground-water contamination exists, the facility will probably be required to excavate soils to the cleanup levels described in the closure plan.

\subsubsection{Demonstrating Clems Closure}

Upon completion of closure, facilities must keep all data documenting closure on hand for three years and submit it to EPA upon request. This documentation should provide evidence that all environmental media were cleaned up to the levels established in the closure plan. The data should address soils, ground water, surface water, and air, as appropriate. Consult the discussion in Section 4.2 on demonstrating clean closure for surface impoundments, which will be largely applicable to tank demonstrations.

\subsubsection{Submit Revised Closure/Post-Closure Plans and Close as a Landfill}

If an owner or operator of a tank system demonstrates to the Regional Administrator that all contaminated soils cannot be practicably removed from the site of the tank system, or decontaminated at the time of closure, then the owner or operator must close the tank system in the same manner as a landfill (40 CFR \& $\$ 264.310$ and 265.310 ). In general, the facility should (1) demonstrate impracticability to EPA, (2) prepare landill closure and post-closure plan or revise the contingent plan as applicable, and then (3) get approval from the Agency.

Facilities without secondary containment should already have a contingent plan on file with EPA and will only need to revise it to address current site conditions when applying for Agency approval to close as a landfill. If it is not necessary to revise the plan, the facility will be able to begin landfill closure immediately after Agency approval. Facilities with secondary containment are not required to submit contingent plans, and are unlikely candidates for closing as a landfill unless significant ground-water contamination has occurred due to unusual leaks, overflows, or spills.

Once the determination to close as a landfill is made, all the closure and post-closure requirements that apply to landfills will then apply to the tank system. The facility must revise the unit's closure plan to reflect closure as a landfill and prepare a post-closure plan. If closure has not yet begun, the revised closure plan must be submitted within 30 days after the determination. The post-closure plan should be drafted and submitted for approval within 90 days after the determination that the site must be closed as a landfill (40 CFR \$\$2 264.118 and 265.118).

If a revised closure plan is necessary, it can build on previously submitted plans (sce Exhibit 4-6, Tank Contingent Closure Plan Sample Outline). During the revision of the closure plan, sections will need to be added describing cover design, stabilization, and monitoring. Since all of the wastes will have been previously 
removed or decontaminated, liquid waste removal will be unnecessary and only a cap will be required to cover the remaining contaminated soils, equipment, or tank system components. Further guidance on closing as a landfill is provided in Section 4.1 of this manual.

The most critical component of closure as a landfill concerns the design, installation and operation of a ground-water monitoring system, as required in $40 \mathrm{CFR}$ Part 264 , Subpart $F$, and a final cover. The process described in these regulations is complicated, requiring characterization of the hydrogeology and ground-water flow patterns. At a minimum, the detection monitoring wells must be capable of sampling specific conductance, total organic carbon, total organic halogen, and other applicable waste constituents. The frequency of monitoring and maintenance activities will be dependent on the specific site conditions, for example, climate, waste type, soil, and vegetation. For further information on how to install and operate a RCRA ground-water monitoring system, see EPA's "RCRA Ground-water Monitoring Enforcement Guidance, Part II: RCRA Ground-water Monitoring Technical Enforcement Document (TEGD), Draft, August 1985." For further information on ground-water monitoring within the context of corrective action, see OSWER Directive *9502.00-6D, "RCRA Facility Investigation Guidance Document," May 1989, and Section 4.2 of this manual. For further information on other RCRA requirements to consider for clean closure or landfill closure, also see Sections 4.1 and 4.2 of this manual.

Because the volume of waste remaining in place at closure will be less than in a typical landfill, it may not be necessary to design a full 3-part RCRA cap (as described in Section 4.1). The cap must be designed to minimize the release of contaminated leachate during the post-closure period and in the long-term. See Section 4.2 for a discussion of alternatives to the full RCRA cap.

\subsubsection{Conducting Post-Closure Care and Monitoring}

Owners or operators of tank systems that close as landfills must conduct post-closure care for 30 years after closure and comply with all post-closure procedural requirements contained in $40 \mathrm{CFR} \$ \$ 264.117$ through 264.120, including maintenance and monitoring throughout the post-closure care period. The EPA Regional Administrator has the authority to extend or reduce the period for post-closure care on a case-bycase basis.

Provisions for the kinds of monitoring and maintenance activities that can reasonably be expected during the post-closure care period must be specified in a post-closure plan. The plan should inciude the following information below:

- Frequency and scope of inspections;

- Procedures for making repairs to the cover;

- Procedure for leachate collection, removal, and treatment;

- Frequency of sampling and monitoring; and

- Maintenance of monitoring systems. 


\subsubsection{Additional RCRA Requirements to Consider}

In addition to the unit-specific closure requirements discussed in this section, the owner or operator should also be aware of the following additional RCRA requirements.

- Corrective Action. Corrective action at facilities handling mixed waste may be required as a part of, or concurrently with, closure activities. See Section 2.1.3.2 for a discussion of corrective action requirements.

- Land Disposal Restrictions (LDRs). LDRs prohibit the land disposal of RCRA hazardous wastes beyond certain statutory dates established by Congress in HSWA. Restricted hazardous wastes and contaminated soils removed at closure are subject to LDRs. See Section 2.1.4 for a discussion of the LDR program.

- Delisting. If the owner or operator of a facility is able to delist the hazardous component of a mixed waste at closure, the waste is no longer subject to the requirements under RCRA. The delisted material becomes a radioactive waste regulated solely by the DOE. However, delisting a waste does not necessarily exempt the facility that handled the waste from RCRA closure requirements. See Section 2.1.2.5 for a discussion of delisting petitions. 


\section{REFERENCES: SECTION 4.6}

API Publication 1604, "Recommended Practice for Abandonment or Removal of Used Underground Service Station Tanks," 1981.

API Publication 2015, "Cleaning Petroleum Storage Tanks," September 1985.

API Publication 2015A, "A Guide for Controlling the Lead Hazard Associated with Tank Entry and Cleaning (Supplement to API RP 2015)."

API Publication 2015B, "Cleaning Open-Top and Covered Floating-Roof Tanks," 1981.

DOE 5820.2A, "Radioactive Waste Management," September 26, 1988.

EPA/530-SW-86-044, "Technical Resource Document for the Storage and Treatment of Hazardous Waste in Tank Systems," December 1986 (OSWER Policy Directive No. 9483.00-1).

EPA/580-SW-87-010, "RCRA Guidance Manual for Subpart G Closure and Post-closure Care Standards and Subpart H Cost Estimating Requirements," January 1987.

EPA/600/2-85-028, "Guide for Decontaminating Buildings, Structures, and Equipment at Superfund Sites," 1985.

EPA/625/6-85-006, "Handbook: Remedial Actions at Waste Disposal Sites," October 1985.

EPA/SW-873, "Closure of Hazardous Waste Surface Impoundments," 1982.

EPA's "Guidance Manual: Cost Estimates for Closure and Posi-closure Plans (Subparts G and H), Volumes I through IV.

EPA's "RCRA Ground-water Monitoring Enforcement Guidance, Part II: RCRA Ground-water Monitoring Technical Enforcement Document (TEGD) (Draft)," August 1985.

National Institute of Occupational Safety and Health (NIOSH) No. 80-106, "Working in Confined Spaces," December 1979.

NFPA No. 30, "Flammable and Combustible Liquids Code," 1984.

NFPA No. 327, "Standard Procedures for Cleaning or Safeguarding Small Tanks and Containers," 1982.

OSWER Policy Directive \#9476.00-5, "Draft RCRA Guidance Manual for Subpart G Closure and Post-closure Care Standards and Subpart H Cost Estimating Requirements, ${ }^{,}$U.S. EPA, January 1987.

OSWER Policy Directive \#9476.00-6, "Final Report/Guidance Manual: Cost Estimates for Closure and Postclosure Plans (Subparts G and H) Volume III - Unit Costs," November 1987. 
OSWER Policy Directive \#9483.00-1, "Technical Resource Document for the Storage and Treatment of Hazardous Waste in Tank Systems," December 1986 (EPA/530-SW-86-044).

OSWER Policy Directive \#9483.00-3, "Questions and Answers Regarding the July 14, 1986 Hazardous Waste Tank System Regulatory Amendments."

OSWER Policy Directive \#9502.00-6D, "RCRA Facility Investigation Guidance Document," May 1989.

"Technical Resource Document for Obtaining Variances from Secondary Containment Requirements for Hazardous Waste Tank System: Volume I - Technology-Based Variance" or "Volume 2 - Risk-Based Variance." 



\section{INCINERATORS}

This section presents the requirements for closure of incinerators containing hazardous and mixed wastes located at DOE facilities. Because incineration is a treatment rather than a disposal practice, closure requires that all wastes from incineration be removed from the facility, and post-closure care is not required.

An incinerator is defined in $40 \mathrm{CFR} \$ 260.10$ as any enclosed device using controlled flame combustion that neither meets the criteria for classification as a boiler nor is listed as an industrial furnace.

A boiler, as defined in $40 \mathrm{CFR} \$ 260.10$, is an enclosed device using controlled flame combustion and having the following characteristics:

(1) (i) The unit must have physical provisions for recovering and exporting thermal energy in the form of steam, heated fluids, or heated gases; and

(ii) The unit's combustion chamber and primary energy recovery section(s) must be of integral design. To be of integral design, the combustion chamber and the primary energy recovery section(s) (such as waterwalls and superheaters) must be physically formed into one manufactured or assembled unit. A unit in which the combustion chamber and the primary energy recovery section(s) are joined only by ducts or connections carrying flue gas is not integrally designed; however, secondary energy recovery equipment (such as economizers or air preheaters) need not be physically formed into the same unit as the combustion chamber and the primary energy recovery section. The following units are not precluded from being boilers solely because they are not of integral design: process heaters (units that transfer energy directly to a process stream), and fluidized bed combustion units; and

(iii) While in operation, the unit must maintain a thermal energy recovery efficiency of at least 60 percent, calculated in terms of the recovered energy compared with the thermal value of the fuel; and

(iv) The unit must export and utilize at least 75 percent of the recovered energy, calculated on an annual basis. In this calculation, no credit shall be given for recovered heat used internally in the same unit. (Examples of internal use are the preheating of fuel or combustion air, and the driving of induced or forced draft fans or feedwater pumps); or

The unit is one which the Regional Administrator has determined, on a case-by-case basis, to be a boiler, after considering the standards in $\$ 260.32$ (Variance to be classified as a boiler). 
An ind ustrial furnace, is defined in $40 \mathrm{CFR} \$ 260.10$ as any of the following enclosed devices that are integral components of manufacturing processes and that use controlled flame devices to accomplish recovery of materials or energy: :

(1) Cement kilns;

(2) Lime kilns;

(3) Aggregate kilns;

(4) Phosphate kilns;

(5) Coke ovens;

(6) Blast furnaces;

(7) Smelting, meling and refining furnaces (including pyrometallurgical devices such as cupolas, reverberator furnaces, sintering machine, roasters, and foundry furnaces);

(8) Titanium dioxide chloride process oxidation reactors;

(9) Methane reforming furnaces;

(10) Pulping liquor recovery furnaces;

(11) Combustion devices used in the recovery of sulfur values from spent sulfuric acid;

(12) Such other devices as the [EPA] Administrator may, after notice and comment, add to this list on the basis of one or more of the following factors:

(i) The design and use of the device primarily to accomplish recovery of material products;

(ii) The use of the device to bum or reduce raw materials to make a material product;

(iii) The use of the device to burn or reduce secondary materials as effective substitutes for raw materials, in processes using raw materials as principal feedstocks;

(iv) The use of the device to burn or reduce secondary materials as ingredients in an industrial process to make a material product;

(v) The use of the device in common industrial practice to produce a material product; and

(vi) Other factors, as appropriate.

The following types of boilers or industrial furnaces are considered to incinerate hazardous waste, as per 40 CFR \$264.340:

- Boilers or industrial furnaces burning hazardous wastes in order to destroy them; or

- Boilers or industrial furnaces burning hazardous wastes for any recycling purpose that the owner or operator has elected to have regulated under Subpar $O$.

Examples of incinerators include liquid injection incinerators, controlled air incinerators, rotary kiln incinerators, fuid bed incinerators, and multiple hearth incinerators.

\subsubsection{What are the Closure Requirements for Incinerators?}

Exhibit 4.7-1 an overview of the key closure requirements for incinerators and references to where in this section more detailed information is provided. 


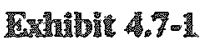 \\ Ovenview of Amplicable statutory and Regulatory Requirements}

The awner or operator must remove and or decontaminate all hazardous waste and hazardous waste residues (including but not limited to ash, scrubber waters, and scrubber sludges) from the incinerator site. Post-elosure care is not required.

Section 4.7 .2

If the owner or operator of an incinerator lails to demonstrate, in accordance with \$261.3(d), that the residue removed from the incinerator is not a hazardous waste, he is considered a generator of hazardous waste and must manage the waste accordingly.

Section 4.7 .2

\subsubsection{Statutory Requirements}

There are no relevant statutory requirements that relate specifically to the closure of hazardous waste incinerators.

\subsubsection{Reguldatory Requirements}

The current regulatory requirements for interim status and permitted facilities are identical. The technical requirements pertaining to closure of incinerators are found in 40 CFR Parts 264 and 265, Subpart O, for permitted (\$264.351) and interim status (\$265.351) facilities, respectively. These requirements are in addition to the procedural requirements found in Subpart $G$, which are discussed in Chapter 3 of this manual.

\subsubsection{Closure of Incinerator Facilities}

In order to close an incinerator, the owner or operator must remove and or decontaminate all hazardous waste and hazardous waste residues (including, but not limited to, ash, scrubber waters, and scrubber sludges) from the incinerator. These wastes and residues must then be managed as hazardous waste unless specifically exempted under $40 \mathrm{CFR} \$ 261.3$. Incinerator ash is generally disposed of in a hazardous waste landfill. There are no post-closure care requirements for owners or operators of hazardous waste incineration facilities as long as they can demonstrate that all hazardous waste and waste residues has been successfully removed or decontaminated. 
The following is an overview of the required closure activities for owners or operators of incinerators:

- Prepare closure plan (Section 4.7.2.1) and

- Conduct closure (Section 4.7.2.2).

The following sections provide guidance on how to properly perform the activities listed above.

\subsubsection{Incinerutor Closure Plau Requirements}

A written closure plan for a incinerators must contain the general information required by $40 \mathrm{CFR}$ Part 264 Subpart $G$, in addition to the technical information found in Subpart $O$. An outline for a sample closure plan for an incinerator is presented in Exhibit $4.7-2$.

\subsubsection{Conduct and Certify Closure}

Removal of wastes and waste residues. In order to properly close an incinerator all wastes, waste residues, contaminated system components, soils, structures and equipment must be either removed or decontaminated. If the owner or operator cannot demonstrate in accordance with the requirements of $40 \mathrm{CFR}$ $\$ 261.3$ (d) that all wastes and residues removed from the facility are not hazardous, the owner or operator becomes a generator of hazardous waste and must manage it in accordance with 40 CFR Part 262 through Part 266. Wastes that are prohibited from land disposal under the land disposal restrictions (LDRs) must be treated by a method that meets the treatment standards of 40 CFR $\$ \$ 268.40$ to 268.44 .

Soils removal. Soils underlying the incinerable waste containment systems should be tested to determine if there has been any contamination. Any soils which have been determined to be contaminated must be removed. The soil should be removed in layers and sampling conducted following removal of each layer. This procedure will help minimize the amount of soil removed. Excavation should be completed as quickly as possible.

Equipment decontamination. The regulations require owners or operators of incinerators to decontaminate all contaminated equipment, tools, and supplies, etc., involved in operating, maintaining, and closing the unit. Guidance on procedures for equipment decontamination is provided in $E P A / 600 / 2-85 / 028$, "Guide for Decontaminating Buildings, Structures, and Equipment at Superfund Sites," 1985.

Closure certification. An independent registered professional engineer and the owner or operator of the incinerator must certify that closure has been conducted in accordance with the approved closure plan. Supporting documentation of the certification must be made available to the Regional Administrator upon request. 
Exhibie 4.7-2

INCINERATOR CLOSURE PLAN SAMPLE OUTLINE

Section

Elements

Facility Description

Incineration System Description

Removal of Inventory

Facility Decontamination

Security Systems

Closure Certification
- General Description

- Topographic map;

- List of other hazardous waste management units and wastes handled in each;

- Hydrogeological information;

- References to other environmental permits; and

- Anticipated waivers or exemptions.

- Overall description;

- Wastes managed and characteristics of feed blends;

- Combustion unit design and capacity;

- Waste handling system design;

- Emission control system; and

- Residuals handling system.

- Estimates of maximum quantity of inventory to be removed;

- Procedures for handling incinerable waste; and

- Procedures for handing wastes not incinerated (e.g., ash and effluents).

- Procedures for decontamination or disposal of equipment, cleaning agents, and contaminated soil.

- General description.

- Activities to be conducted and

- Documentation. 
Schedule of Closure
- Expected year of closure conly for interim status facilities without approved closure plans;
- Time required to decontaminate and/or remove waste, and for final closure; and
- Support for deadline extensions.

Source: OSWER Policy Directive No. 9476.00-5, "RCRA Guidance Manual for Subpart G Closure and PostClosure Care Standards and Subpart H Cost Estimating Requirements (Draft)".

\subsubsection{Adduional RCRA Requirements to Consider}

In addition to the unit-specific closure requirements discussed in this section, the owner or operator should also be aware of the following additional RCRA requirements.

- Corrective Action. Corrective action at facilities handling mixed waste may be required as a part of, or concurrently with, closure activities. See Section 2.1.3.2 for a discussion of corrective action requirements.

- Land Disposal Restrictions (LDRs). LDRs prohibit the land disposal of RCRA hazardous wastes beyond certain statutory dates established by Congress in HSWA. Restricted hazardous wastes and contaminated soils removed at closure are subject to LDRs. See Section 2.1.4 for a discussion of the LDR program.

- Delisting. If the owner or operator of a facility is able to delist the hazardous component of a mixed waste at closure, the waste is no longer subject to the requirements under RCRA. The delisted material becomes a radioactive waste regulated solely by the DOE. However, delisting a waste does not necessarily exempt the facility that handled the waste from RCRA closure requirements. See Section 2.1.2.5 for a discussion of delisting petitions. 


\section{REFERENCES: SECTION 4.7}

EPA/530-SW-88-018, "Hazardous Waste Incineration: Questions and Answers," April 1988.

EPA/600/2-85-028, "Guide for Decontaminating Buildings, Structures, and Equipment at Superfund Sites," 1985.

OSWER Policy Directive \#9476.00-5, "Draft RCRA Guidance Manual for Subpart G Closure and Post-closure Care Standards and Subpart H Cost Estimating Requirements," U.S. EPA, January 1987.

OSWER Policy Directive $9502.00-6 D$, "RCRA Facility Investigation Guidance Document," May 1989. 



\section{MISCELLANEOUS UNITS}

This section presents the requirements for closure and post-closure care of miscellaneous units containing hazardous and radioactive mixed wastes located at DOE facilities. The standards for miscellaneous units (found in Part 264, Subpart $X$ ) are designed to provide generic standards for hazardous waste management units not specifically addressed under the other unit-specific RCRA regulations.

A miscellaneous unit is defined in $40 \mathrm{CFR} \$ 260.10$ as a hazardous waste management unit where hazardous waste is treated, stored, or disposed of and that is not a container, tank, surface impoundment, pile, land treatment unit, landfill, incinerator, boiler, industrial furnace, underground injection well with appropriate technical standards under 40 CFR Part 146, or unit eligible for a research, development, and demonstration permit under $\$ 270.65$. Exhibit 4.8-1 below provides examples of units EPA has identified that can be considered miscellaneous units and some that do not meet the definition.

Exhibint 4.81

Examples of Units that are Inchuded or Excluded from the Defintition of Miscellanedus Inat

Examples of Units Included

- Placement of Hazardous Waste in Geological Repositories

- Placement of Hazardous Waste in Deactivated Missile Silos

- Thermal Treatmem Units Other Than Incinerators

- Open Burning/Open Detonation of Explosive Wastes

- Certain Chemical, Physical, and Biological Treatment Units
Dxamples of Units Exeluded

- Treatment, Storage, and Disposal in Unitu Currendy Regulated Under Part 264

- Open Burning of Nonexplosive Hazardous Waste

- Units Excluded From Permituing Under Part 264 and 270

Mobile Treatment Units

- Placement of Hazardous Waste Underground that is Currently Regulated Under Part 146

- Enclosed Bupldings Used for Treatment, Storage, or Disposal

- Research, Development, and Demonstration Units Covered Under $\$ 270.65$ 
Prior to promulgation of Part 264, Subpart X, EPA developed interim status regulations for three types of units not currently addressed under Part 264: thermal treatment units (Part 265, Subpart P); chemical, physical, and biological treatment units (Part 265, Subpart Q), and underground injection wells (Part 265, Subpart R). In developing standards for permitted units in 1982, EPA decided to promulgate general standards for miscellaneous units, including those covered under Part 265, Subparts $P$ and $Q$, rather than unitspecific standards for a broader number of units. Underground injection wells are not considered miscellaneous units, but are subject to permits-by-rule under the underground injection control (UIC) program of the Safe Drinking Water Act (SDWA) (see Section 4.9).

\subsubsection{What wre the Closure Requirements for Miscellaneous Units?}

Exhibit 4.8-2 provides an overview of the key closure requirements for miscellaneous units and references to where in this section more detailed information is provided.

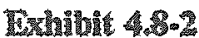

\section{Onerview of Applicable Stuturory and Regulatory Rementrements}

Closure plans must describe the procedures and schedules for closing all miscelnaneous undists.

Section $4,8.2$

Postctosure plans are required for miscellaneous units that leave wastes-in-place.

Section 4.82

Miscellaneous units must be closed in a manner hat ensures protection of human healuh and the covirominent.

Section 4.8 .1

\subsubsection{Stoutory Requirements}

There are no relevant statutory requirements specific to the closure of miscellaneous units.

\subsubsection{Regullatory Requirements}

The regulations governing miscellaneous units are found in 40 CFR Part 264, Subpart X (\$264.600264.603). $40 \mathrm{CFR} \$ 264.601$ addresses standards for protecting the subsurface (including ground water), surface water, wetlands, soils, and air. The regulations provide a number of factors to consider to ensure that these environmental media are protected during the operation, closure, and post-closure care period of miscellaneous units. Factors in the prevention of any releases that may endanger human health or the 
environment due to migration of waste constituents in or on the subsurface, surface, groundwater, or air include:

- The existing quality of the medium;

- The proximity of the unit to surface and ground-water sources; and

- The volume, and physical and chemical characteristics of the waste, including its potential for migration or for the emission of hazardous constituents into the air.

Post-closure care requirements for miscellaneous units are located in 40 CER \$264.603. These provisions require that miscellaneous units in which all wastes cannot be removed at closure, must be maintained in a manner that complies with the general performance standards of $\$ 264.601$. The procedures for completing these activities must be specified in the post-closure plan.

Subpart $\mathrm{X}$ will not supersede or replace any requirements pertaining to specific hazardous waste management units addressed in other subparts of Part 264. For example, 40 CFR \$264.175 stipulates that container storage areas must have a secondary containment system to drain and remove leakage. This requirement may not be evaded by seeking a permit under Subpart $\mathrm{X}$.

Miscellaneous units permitted under Subpart $\mathrm{X}$ that meet the RCRA definition of "land disposal" unit may not avoid the Part 268 restrictions on land disposal of untreated or improperly treated hazardous waste. Any hazardous waste subject to land disposal restrictions that is placed into a miscellaneous "land disposal" unit must be treated prior to land disposal in compliance with a treatment standard promulgated under Part 268 , unless the owner or operator submits a no migration petition that demonstrates, to a reasonable degree of certainty, that there will be no migration of hazardous constituents from the unit for as long as the waste remains hazardous.

\subsubsection{Closure of Miscellaneous Units}

The following is an overview of the required closure activities for miscellaneous units:

- Prepare a closure plan;

- Prepare a post-closure plan if applicable;

- Conduct closure; and

- Conduct post-closure care if applicable.

Because there are no specific requirements for these activities at miscellaneous units, the closure activities required at such a unit will depend on its design and waste management approach. The activities will mirror closely the required activities for the most similar hazardous waste management unit addressed specifically in 40 CFR Parts 264 and 265. Thus, the closure requirements for certain chemical treatment units may be similar to those for surface impoundments and/or tanks (e.g., clean closure may be preferred). The closure and post-closure care activities for wastes placed in a geologic repository may be more similar to those applicable to landfills (e.g., ground-water monitoring may be required). 
In most cases, therefore, guidance on closure and post-closure requirements for miscellaneous units can be obtained from the discussions of general closure requirements in Chapter 3 and unit-specific requirements contained in Chapter 4.

\subsubsection{Closure and Post-Closure Care of Interim Status Miscellaneous Units}

40 CFR Part 265 contains specific standards for interim status thermal treatment and chemical, physical, and biological treatment units in Part 265 Subparts $P$ and $Q$ respectively. In addition, Part 265 Subpart $R$ was reserved for regulations governing underground injection wells, which are now regulated by the Underground Injection Control (UIC) program of the Safe Drinking Water Act (SDWA).

\subsubsection{Thermal Treatment Units}

Subpart $P$ of Part 265 regulates interim status thermal treatment units. These regulations apply to hazardous waste thermally treated in devices other than enclosed devices using controlled flame combustion, except as $\$ 265.1$ specifies otherwise. At closure, the owner or operator of an interim status thermal treatment unit must remove all hazardous waste residues from the treatment process (40 CFR $\$ 265.381$ ). Thus, the closure requirements for such thermal treatment units are "clean closure" requirements.

Open burning of hazardous waste is prohibited except for the open burning and detonation of waste explosives, which is regulated for interim status facilities under Part 265 Subpart $P$. These regulations do not provide additional requirements for closure of open burning and detonation units.

\subsubsection{Chemical, Physical, and Biological Treatment}

Part 265, Subpart $Q$ contains standards for owners and operators of facilities that treat hazardous wastes by chemical, physical, or biological methods in other than tanks, surface impoundments, and land treatment facilities, except as \$265.1 provides otherwise.

At closure, all hazardous waste and hazardous waste residues must be removed from the treatment processes or equipment, discharge control equipment, and discharge confinement structures. Unless the owner or operator can demonstrate in accordance with $\$ 261.3$ (c) or (d) that any materials removed are not hazardous, he becomes a generator and must comply with all standards applicable to generators as specified in Parts 262, 263, and 265.

\subsubsection{Additional RCRA Requirements to Consider}

In addition to the unit-specific closure requirements discussed in this section, the owner or operator should also be aware of the following additional RCRA requirements.

- Corrective Action. Corrective action at facilities handling mixed waste may be required as a part of, or concurrently with, closure activities. See Section 2.1.3.2 for a discussion of corrective action requirements.

- Land Disposal Restrictions (LDRs). LDRs prohibit the land disposal of RCRA hazardous wastes beyond certain statutory dates established by Congress in HSWA. Restricted hazardous wastes and contaminated soils removed at closure are subject to LDRs. See Section 2.1.4 for a discussion of the LDR program. 
- Delisting. If the owner or operator of a facility is able to delist the hazardous component of a mixed waste at closure, the waste is no longer subject to the requirements under RCRA. The delisted material becomes a radioactive waste regulated solely by the DOE. However, delisting a waste does not necessarily exempt the facility that handled the waste from RCRA closure requirements. See Section 2.1.2.5 for a discussion of delisting petitions. 



\section{UNDERGROUND INJECTION WELLS}

This section presents the requirements for closure and post-closure care of underground injection wells disposing of hazardous and mixed wastes at DOE facilities. 40 CFR \$260.10 states that, underground injection is the subsurface emplacement of fluids through a bored, drilled, or driven well, or through a dug well where the depth of the well is greater than the largest surface dimension. Facilities that inject hazardous wastes are regulated under RCRA and under regulations promulgated pursuant to the Underground Injection Control (UIC) program of the Safe Drinking Water Act (SDWA), found at 40 CFR Parts 144 through 146.

Owners or operators of hazardous waste injection wells must obtain a RCRA permit by rule. In order to receive such a permit, the owner or operator must first obtain a UIC permit. Certain additional requirements must also be adhered to, depending upon when the UIC permit is obtained. Closure activities (e.g., preparation and submittal of closure and post-closure plans, capping and abandonment, and closure certification) are conducted through the UIC program and do not involve RCRA permit writers.

Like RCRA, the UIC program requirements are implemented by States with approved UIC programs. Section 1421 of the SDWA requires that Federal minimum guidelines be established with which the State UIC programs must comply. State programs are subject to EPA approval and may be considerably more stringent than the Federal guidelines. A State in which an approved UIC program exists is said to have primacy. Underground injection wells located in States without primacy are only subject to Federal UIC standards. Presently, 27 States have primacy for Class I underground injection wells. A list of these States can be found in 40 CFR Part 147.

\subsubsection{What are the Closure Requirements for Underground Injection Wells?}

Exhibit 4.9 .1 is an overview of the key closure requirements for underground injection wells and references to where in this section more detailed information is provided.

\subsubsection{Statutory Requirements}

Section 3005 (a) of the Hazardous and Solid Waste Amendments of 1984 states that each person owning or operating an underground injection well or planning to construct a new well for the disposal of hazardous waste must have a permit. However, instead of establishing its own specific requirements for the permitting of injection wells, RCRA allows UIC-permitted wells to receive a RCRA permit as long as the wells in question meet certain additional requirements.

Underground injection wells receiving UIC permits before November 8,1984 , must only comply with the general provisions for any injection well that manages hazardous waste in order to receive a RCRA permit by rule. These provisions are found in $40 \mathrm{CFR} 144.14$ and include notification, identification, manifesting, recording and reporting, and personnel training requirements. 


\section{Cxhibur 4.9-1 \\ Overview of Applicable Stanutory and Regultory Requirements}

At closure, owners or operators of underground injection wells must plug and abandon the wells.

Section 4.9 .2

RCRA permits can be granted to approved UIC wells on permit by nule basis provided the wells have a UIC permit and meet certain RCRA requirements.

Section 4.9.1.1

Underground injection wells receiving UIC permits after November 8,1984 mussis comply with the RCRA corretive action requirements of 40 CFR $\$ 264.101$.

Section 4.9.1.1

Underground injection wells are subject to the Land Disposal Restrictions (LDRs) contasned in $40 \mathrm{CFR}$ Part 268.

Section 4.9 .3 .1

Injection wells receiving UIC permits after November 8,1984 must comply with the RCRA corrective action requirements for solid waste management units of $40 \mathrm{CFR} \$ 264.101$; and, for facilities where the UIC well is the only unit that requires a RCRA permit, they must comply with the RCRA Part $B$ information requirements for solid waste management units located in 40 CFR $\$ 270.14(d)$.

In meeting the corrective action requirements, underground injection wells must meet these conditions:

- Corrective action is required regardless of when the hazardous waste was injected;

- The form and schedule of corrective action will be specified in the permit;

- Corrective action may be required beyond the boundaries of the underground injection facility, if necessary to protect human health and the environment.

RCRA Section $3004(f)$ stipulates that underground injection wells are subject to LDRs. More information LDRs can be found in Section 2.1.4 of this manual. 


\subsubsection{Regulatory Requirements}

EPA promulgated UIC regulations in 40 CFR Parts 144 through 146 for five types of underground injection wells, including hazardous waste injection wells. 40 CFR 144.6 classifies injection wells according to the fluids that are injected and the subsurface formation into which the injection occurs as follows:

- Class I: Hazardous waste, industrial, or municipal wells that inject fluids beneath the lowermost formation containing an underground source of drinking water within $1 / 4$ mile of the well bore.

- Class II: Wells used to inject fluids for enhanced recovery of oil and gas, including fluids brought to the surface by oil and gas production.

- Class III: Wells used to inject fluids for the extraction of minerals.

- Class IV: Hazardous or radioactive waste wells that inject fluids into or above a formation containing an underground source of drinking water within $1 / 4$ mile of the well bore.

- Class V: All other injection wells.

Only Class I and Class IV wells contain hazardous and mixed wastes. However, 40 CFR 144.14 forbids the construction of any new Class IV injection wells and also required that any Class IV wells already in operation close within six months after the effective date of an approved UIC program. Because these provisions essentially eliminate the possibility of currently operating a Class IV injection well, only Class I wells are discussed in this section. Note that wells used to inject contaminated ground water that has been treated and is being reinjected into the same formation from which it was withdrawn are not prohibited from operating if such injection is approved by EPA in accordance with CERCLA or RCRA corrective action provisions. (See Appendix E, EPA Memorandum, "Applicability of Land Disposal Restrictions to RCRA and CERCLA Ground-Water Treatment Reinjection Superfund Management Review,"12/27/90 and DOE Memorandum, "Applicability of Land Disposal Restrictions to RCRA and CERCLA Ground-Water Treatment Reinjections," $3 / 28 / 90)$.

\subsubsection{Closure of Underground Injection Wells}

The technical requirements for the closure and post-closure care of Class I hazardous waste injection wells are located in $40 \mathrm{CFR} \$ \$ 144.71-73$. Exhibit 4.9-2 outlines closure procedures for underground injection wells.

The following is an overview of required closure activities of underground injection wells.

- Prepare closure plan (4.9.2.1)

- Prepare post-closure plan (4.9.2.2)

- Prepare and plug wells (4.9.2.3) 
- $\quad$ Conduct post-closure activities (4.9.2.4)

Exhinitic 49.92

Underground Injection Well Closuse Prowdures (4O CF R S146.71-73)

Closure

- Conduct hackground injection ane pressure and mechanical integrity tests prior to closing wells

Plug wells

Posta-Closure

- Subruil closure report

- Conatuct injection zone pressure and ground-water nonitoring

- Provide information and maintain records regarding well operations

- Post-closure care continues unith the pressure in the injection zone declines to the point where the well's cone of infuence does not intersect with the lowermost

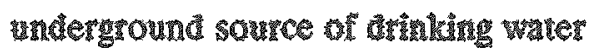

\subsubsection{Closure Plan Requirements}

A written closure plan is required for all closures of underground injection wells. The specific requirements for closure of an underground injection well are found in $40 \mathrm{CFR} \$ 146.71$ (a). The plan should be submitted as a part of the UIC permit application process and must be resubmitted if any significant changes are made to the method of closure. The regulations state that at a minimum, the closure plan should include the following:

- The number and types of plugs used;

- A description of the material used in plugging;

- The location and top and bottom elevation of each plug;

- The method of placement of each plug;

- The amount, size and location (by depth) of casing and any other materials left in the well;

- The method and location where casing is to be parted, if applicable; and 
- Any proposed test or measure to be made on the well.

A Class I injection well that temporarily ceases operations can remain open provided that the owner or operator receives authorization from the Director of the applicable UIC program. If such a well remains open and in disuse for more than two years, the owner or operator must notify the director at least 30 days prior to continuing injection activities. Also, the owner or operator must notify the Director at least 60 days prior to closing the well. Within 60 days after closing a well, or if it is earlier, at the time of the next scheduled quarterly report to the Director, a closure report must be also submitted to the Director. The purpose of the closure report is to detail any differences between the actual methods used during closure and those contained in the closure plan.

\subsubsection{Post-Closure Plan Requirements}

A written post-closure plan must also be submitted along with the UIC permit application and must be resubmitted if any significant alterations are made to the post-closure process. The regulations (40 CFR \$146.72) state that at a minimum, the post-closure plan should include the following:

- Pressure of the injection zone before the well began operations;

- The anticipated pressure in the injection zone at the time of closure;

- The predicted time until pressure in the injection zone decays to the point that the well's cone of influence does not intersect with the base of the lowermost underground source of drinking water;

- The predicted position of waste front at closure; and

- The status of any required corrective action.

\subsubsection{Preparing and Plugging Wells}

The closure procedure for underground injection wells is designed to protect underground sources of drinking water from contamination from either injected fluids or fluids displaced by injection. The closure procedure involves two steps -- well preparation and well plugging.

Well preparation involves activities necessary to ensure the proper environment for setting the plug and the general integrity of the well prior to plugging. ${ }^{31}$ Well preparation involves the following steps:

- Collecting available hydrogeological and well construction data;

- Removing tubing and packer;

- Inspecting well;

31 "Final Technical Manual: Injection Well Abandonment," prepared for U.S. EPA/Office of Drinking Water by Geraghty \& Miller, Inc. 
- Cleaning out well;

- Selecting plugging fluid;

- Establishing plugging fluid;

- Selecting cement slurry; and

- Submitting certified closure report.

Collecting available data. Knowledge of the location and characteristics of underground sources of drinking water, the injection zone and confining beds, and any intervening geologic formations is essential to plan a well plugging strategy. Information on well construction is also necessary because it influences the design and location of plugs and the long-term structural integrity of the well. Knowledge of injection zone pressure is necessary to ensure that it is properly controlled during plugging.

Removing tubing and packer. Injection well tubing must be removed first to make room for the plug. The packer is a device attached to the bottom of the tubing to prevent liquids from moving back up through the tube. The packer can be pulled out with the tubing or, if this is not possible, it may be ground-up with a drill and the debris removed via fluid circulation.

Inspecting well. The objective of well inspection is to determine the mechanical integrity of the well. The types of tests which may be used to determine mechanical integrity include:

- Liquid or gas pressure tests;

- Radioactive tracer surveys;

- Noise, temperature, pipe evaluation, or cement bond logs; and

- Any other test the Director deems appropriate.

Cleaning out well. The purpose of well cleanout is to ensure that effective plugging can take place. Surface debris, formation material, old casing and downhole equipment must be removed.

Selecting plugging fluid. The fluid in the well must provide a suitable environment for placement of plugs. Desirable qualities in a plugging fluid include:

- Ability to provide sufficient hydrostatic head (weight);

- Ability to remain in place for an extended period; and

- Physical and chemical stability.

Establishing plugging fluid system. The plugging fluid is established in the well with a drill pipe or other tubing, thus the plugging fluid will be diluted with the original fluid. Several circulations of the plugging fluid will be necessary to ensure the desired properties are maintained throughout the fluid. 
Selecting cement slumy. The slurry must provide a durable and impermeable barrier to the flow of liquid through the borehole. The slurry must bond with the casing or underlying rock formation and be designed to withstand any special pressure, temperature, or compatibility problems.

Closure Report. No later than 60 days after closure of the well, the owner or operator must submit a closure report to the Director, certified by the person who performed closure (and the owner or operator if the two are not the same). The closure report must state that the well was closed in accordance with the approved closure plan.

Well plugging is the final stage of the closure procedure for underground injection facilities. The purpose of a cement plug is to prevent the migration of fluids containing hazardous constituents into or between underground sources of drinking water. The cement plugs may be placed using one of four techniques:

- The Balance Method involves displacing the plugging fluid with a cement slurry that is placed through drillpipe or tubing into the borehole. The amount of cement placed must match the level of cement in the drillpipe or tubing to the level of cement required in the borehole. The tubing is then slowly pulled back out of the top of the cement, leaving behind a solid plug of cement with minimal contamination by the plugging fluid.

- The Dump Bailer Method utilizes a bailer lowered into the well on a wireline. A measured amount of cement is then released at a desired depth. Generally, a bridge plug or cement basket is previously placed at the specified depth.

- The Two Plug Method involves a top plug, bottom plug, and a latch-down type of plug catcher. The procedure begins by running the placement tubing with the attached plug catcher into the hole to the depth desired for the bottom of the cement plug. The bottom plug, followed by the desired volume of cement slurry, is pumped into the pipe. The top plug is placed on top of the cement slurry and followed by a plugging fluid. When the bottom plug reaches the catcher, it passes through and out into the well. The cement slurry is then displaced into the well; when the top plug reaches the plug catcher, it is unable to pass through preventing any further displacement of fluid.

- An alternate method may be approved by the Director.

For more information on the technical aspects of underground injection well plugging and abandonment techniques, see U.S. EPA, "Final Technical Manual: Injection Well Abandonment," prepared for the Office of Drinking Water by Geraghty \& Miller, Inc.

\subsubsection{Post-Closure Activities}

Post-closure care at UIC facilities generally involves monitoring of the water chemistry and the injection zone pressure. The primary goal of monitoring at UIC facilities is to ensure that plugging activities were conducted properly so as to prevent displaced fluids or hazardous constituents from the injected fluids from contaminating underground sources of drinking water. Drastic changes in water chemistry (i.e., the level of certain chemicals present) are indications of hazardous constituent migration from the injection well. Injection 
zone pressure is important because the higher the pressure in the injection zone, the greater the potential for hazardous constituent migration.

The regulations do not include a standard period for post-closure care at UIC facilities; instead, monitoring must continue until the pressure in the injection zone declines to the point where the well's cone of influence does not intersect with the base of the lowermost underground source of drinking water.

The type of monitoring required is specified by the Director in the permit. In making a determination of monitoring requirements, the Director shall consider site specific factors (i.e., geohydrology, etc.) as well as the ability of particular types of monitoring wells to detect migration of hazardous constituents. Four types of monitoring may be applicable to UIC facilities:

- Shallow ground-water monitoring;

- Monitoring of the injection wellbore itself;

- Monitoring outside the well, above the injection zone; and

- Monitoring outside the well, within the injection zone.

The shallow ground-water monitoring requirements are the same as those for RCRA hazardous waste treatment and disposal facilities. These requirements are discussed in greater detail in Chapter 2 of this manual. Water chemistry is the parameter being measured by this type of monitoring.

The most effective means of measuring the injection zone pressure parameter is through the well borehole itself. Such a monitoring system can be readily achieved by replacing the wellhead assembly with a single master valve suitable for wireline access.

Monitoring wells above and within the injection zone are most appropriately suited for monitoring the water chemistry parameter. The objective of monitoring wells above the injection zone is to detect migration plumes of hazardous constituents. Monitoring wells within the injection zone are most appropriate for measuring the changes in the waste composition during the post closure period.

The owner or operator of a UIC facility must provide information (eg. survey plats and well locations) and retain for three years following closure, records reflecting the nature, position, and volume of the hazardous waste injected. In addition, the owner or operator of the well, and the owner of the property on which is is located, must record a notation on the deed that will provide any future buyer of the property with information on the nature of injection activity and the name of the appropriate UIC regulatory authority. Guidance on preparing a Notice in Deed is located in Chapter 3.

More technical information on the post-closure monitoring requirements for underground injection wells can be found in, "Monitoring Class I Hazardous Waste Injection Well Facilities During the Post-Closure Period: A Discussion of Technical Implications, Options, and Estimated Costs, prepared by Larry Browning Geological Engineering Specialties, December, 1986. 


\subsubsection{Additional RCRA Requirements to Consider}

In addition to the unit-specific closure requirements discussed in this section, the owner or operator should also be aware of the following additional RCRA requirements.

- Corrective Action. Corrective action at facilities handling mixed waste may be required as a part of, or concurrently with, closure activities. See Section 2.1.3.2 for a discussion of corrective action requirements.

- Land Disposal Restrictions (LDRs). LDRs prohibit the land disposal of RCRA hazardous wastes beyond certain statutory dates established by Congress in HSWA. Restricted hazardous wastes and contaminated soils removed at closure are subject to LDRs. See Section 2.1 .4 for a discussion of the LDR program.

- Delistivg. If the owner or operator of a facility is able to delist the hazardous component of a mixed waste at closure, the waste is no longer subject to the requirements under RCRA. The delisted material becomes a radioactive waste regulated solely by the DOE. However, delisting a waste does not necessarily exempt the facility that handled the waste from RCRA closure requirements. See Section 2.1.2.5 for a discussion of delisting petitions. 
DOE Memorandum, "Applicability of Land Disposal Restrictions to RCRA and CERCLA Ground-Water Treatment Reinjections," 3/28/90.

EPA Memorandum, "Applicability of Land Disposal Restrictions to RCRA and CERCLA Ground-Water Treatment Reinjection Superfund Management Review," 12/27/90.

Geraghty \& Miller, Inc., "Final Technical Manual: Injection Well Abandonment," prepared for EPA Office of Drinking Water.

Larry Browning Geological Engineering Specialties, "Monitoring Class I Hazardous Waste Injection Well Facilities During the Post-closure Period: A Discussion of Technical Implications, Options, and Estimated Costs," December 1986. 
APPENDIX A

EPA's "Contained-in" Policy 


\section{UNITED STATES ENVIRONMENTAL PROTECTION AGENCY}

WASHINGTON. O.C. 20460

NOV 131986

OFIC: 0

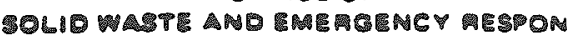

MEMORANDUM

SUBJECT RCRA Regulatory Status of Contaninated Ground Water

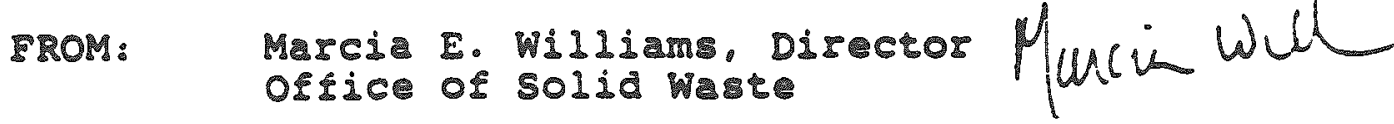

TO: Patrick Tobia. Director

Wate Managemant Division. Region IV

This is in response to your memorandun of September 18. 1986. Iegarding the regulatory trus of ground water contaminated with hazardou wate leachate. To answer this question. one iste hre to determine the ctatur of ground water. under the regulations. ground water contained in the aguifer is not considered solid waste, ince it is not "discerded" in the sense of being abandoned. recycled. or inherenty wate-like ar those trims are defined in the

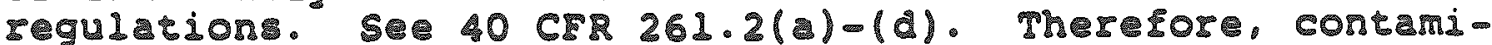
neted ground weter cannot be considered hazardous waste via the mixture rule (i.e.. to have a hazardous waste misture, hazardous weste must bo mixed with a solid waste: se $40 \mathrm{CFR} 261.3(\mathrm{~s})(\mathrm{z})(\mathrm{iv}))$. Nevertheless. ground wates contamineted with hazardous west lechate is still subject to regulation ince it contains a hazdous wate. Therefore.

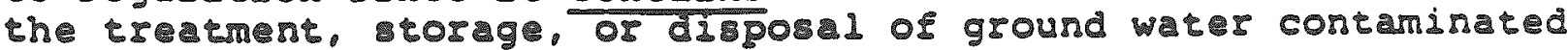
with hamardou wast leachere must be handied as if the ground weter itsel leachet is subject to regulation under subtitle $C$ of RCRA. Mowever, if the ground water is treated such that it no longer contains hazardou wate. the ground water would no longer be ubject to jegulation under subtitle C Of RCRA.

If Mis memo more precilely explain the porition on ground water contamination oresented in John Skinner's memo dated December 26. 1984. 
Taking this 1nterpretation and oply1ng 1t to the example in your menorandum, the ground weter conta1ning a 11sted hamadous wate, once collected. 13 subject to regulation under the hazardous waste regulations. However, 15 as result of treatment, the ground weter no longer contalns the hazardous wate leachet, the ground water would no Ionger be subject to the hazardous waste rules.

Your letter also rasses the question of treatment of ground water within the context of corrective action. Is the corrective action is taken at an Interim status fac1lity $1 n$ compliance wlth $\$ 3008(\mathrm{~h})$ order, treatment can take place. We are considering the possibl11ty of amending the regulations to clarisy the relationship between corrective action and the reconstruction ban $(\$ 270.72(\mathrm{e}))$. More broady. the Afency is currently exanining the 13 sue of whether permits should be required for any corrective actlons. We re also developing rules Ior corrective action under RCRA \$3004(U). Unt11 this analysis is coupleted, 1 the correctlve action takes place t permitted pac1lity. 1 t can be handled as a permit nodileation.

Please reel free to call Mtt straus, of my starf, 1 f you have any surther questlons; h1s telephone number 15475 . 8551 (FTs).

cc: Hazarous Waste D1v1sion D1rectors,

Reflons I-III and $V-X$

Gene Lucero, OWPE

Lloyd Gueres, OWPE

Mark Grenwood, OGC

Steve SIIverman, OGC 


\section{MAN 241089}

\section{MEMOMAMUR}

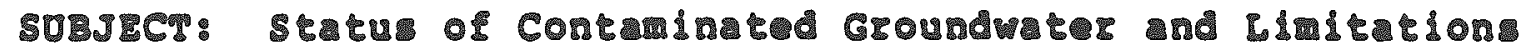
on Dispora 1 and Reuse

EROM:

Sylvia I. Lowrance oimecoz<smiles>CC(C)(C)C</smiles><smiles>CCCCC(=O)C(C)(C)C</smiles>

TO:

JeIf ziston, Disector

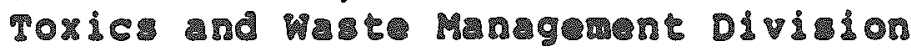

Region IX

In your weno of December 16.198 . 16 the atcrehed

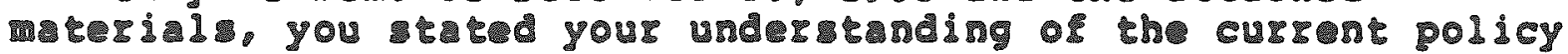
on the clasisicetion of contaninated groundwet and decribed issuer which heve risan in Californi regarding reuse of contrintted groundwater son suparund alte.

You have accurately gtated the effectr of the "contajnec in policy which govern situations such as the one you have decribed. Bitely, a contaninted groundwater which has been treated such thet it no longer contain hasardous constituents. need not bo considerd to be hararous wate and barejcil reuse of the mate is permicible. We have not yet jssued definitive guidance on Levels below uhich the groundwer is no longer considered to contain hazardous weres. until such definitive guidace is irsued, the Region

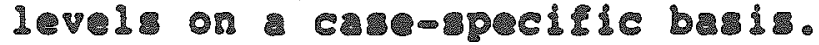

It a level of haserdou warter which ma rena 1.vel in the De mind by OSN. I lnow that teglon Ix ha ben participaing in the

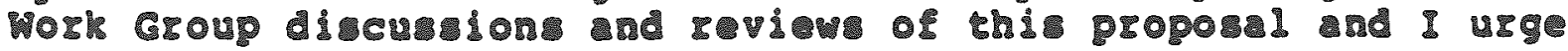
you to contrue thi involvement.

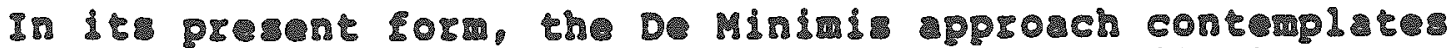

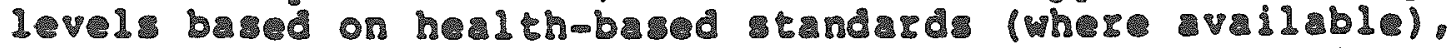
asuming discet erporure. With respet to the contiturnts

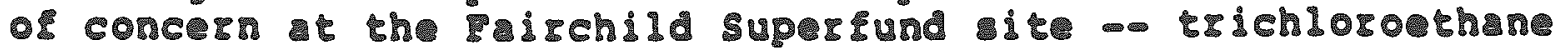




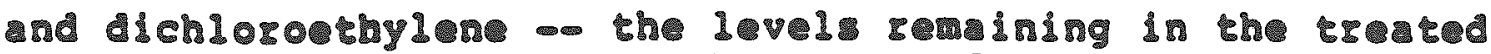
groundwater me mel bew the MCLs ad would therefore be consistert

I5 you have aditiond guetione pleare contact David ragan

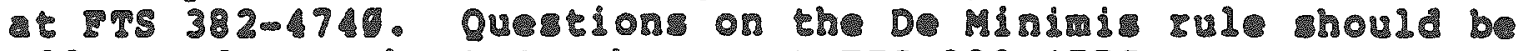
adrersed to Robert Scrbery at TS $382-477$.

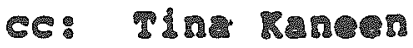

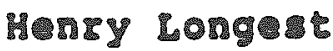


APPENDIX B

DOE Guidance Memorandum on RCRA Corrective Action Requirements 


\section{memorandum}

DATE January 2, 1990

AEPLY TO

ATTN OF EH- 231

sunec Corrective Action PIan, Interim Maasures Guidance, Nat1onal Strategy, and Model Consent order.

TO

Distr1bution

The purpose of this memorandun is to provide DOE and DOE contractor personnel with information and guldance on the Corrective Action requirements under the Resource Conservation and Recovery ACt (RCRA).

The Hazardous and Sol1d Waste Amendments (MSWA) or 1984 greatly expanded the authority under RCRA fOr rogulring corrective action for releases or hazardous wates and constluents, as well as hazardous substances identified in Section 101(14) of the Comprehensive Environmental Response, Compensaton, and Liab111ty Act (CERCLA) at RCRA permitted and 1nterim status facilities that manege hazardous wastes.

EPA 1: authorized to address corrective acton through the permit

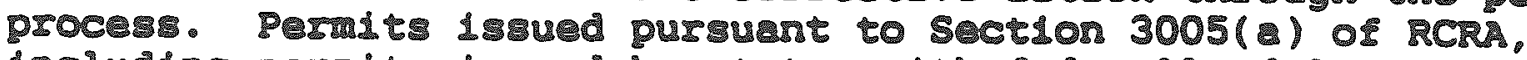
Including permits issued by trtes with êderally delegated authority to imolement HSWA provisions or RCRA program, are reguired to contaln corrective ation regulrenents.

AddItIonally. EPA, pursuant to Section 3008(b) of RCRA, meY regulre corrective ection at unpernitted faclilties subject to Inter1m atatus regulisments.

Section $3004(u)$ of RCRA regulres "Corrective action for II releases of hazardous wastes or constlturnte fron any solld waste managenent unit at treatment, storage, and disposal facilities

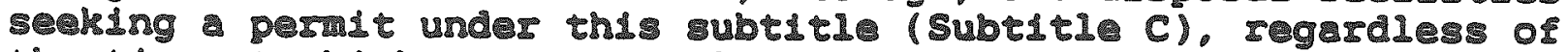

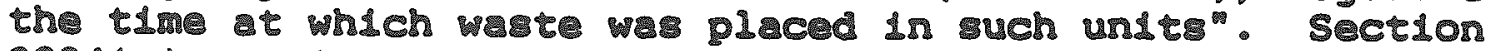
3004(v) requires corrective action bo takn beyond the faclidty property boundary where necessary to protect hum health and the environment unless the owner or operator of the facility can demonstrate thet, desplte the omber or operator's best efforts. the owner or operator was unable to obtain permission to undertake such action".

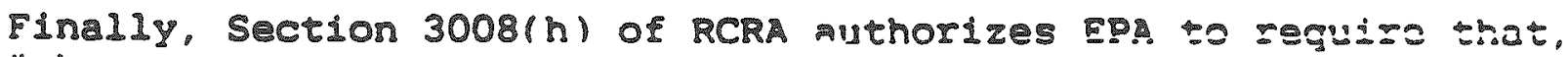
"Whenever, on the basis of any information, the Administrator determines there has been release of hazardous waste into the environment from a facility authorized to operate under Section $3005($ e) of Subt1tle $C$. the Administrator may 1ssue an order requiring corrective action, or other such response measure as demed necessary to protect human health of the enviromnent". 
It should be noted that federal iacilities, Including those operated by DOF and DOE contractors, are subject to the same basic corrective acton requirements which apoly to any iccility omed or operated by private parties.

The RCRA correctlve action process conslets of four stages (\$1gure 1): RCRA Facility Asersment (RTA), RCRA Facility Invertigation (RI). Correctlve Maesres Study (CMS), and Corrective Measures Implementation (CMI).

An RF I performed to determine areas of potent1al release of hemardous westes or hazardous substances at RCR facllitles and to 1dant1fy release or mupected rolerses of hazerdour wates or substances ned1ng further Investlgatlon. In most cases the RFA asessment and report w11 be prepared by the DOE Eac1lity: however. EPA parsonnel may elect to prepare IFA reoort themselves using informeton supplied to the agency by the saclity in conjunction with on-s1te ingpertons.

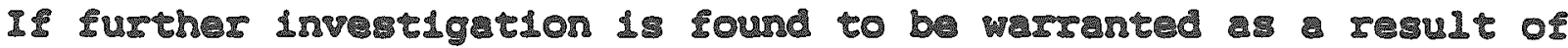
the REA, the faclilty w11 conduct an RFI to oveluete the reture and artent of ths releese of harerdous werte and constitunte. and to gathar usflelent lniorution to rupport Chs. If tho

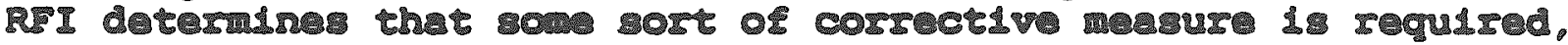
then CMS is conducted.

The purporo of as 15 to devalog and ovaluate correctre mesures ltarnetive and to reconnan a ind cosrect mesure or

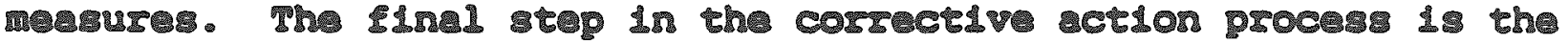
CI. The objectiv of tho CMI Is to design, construct, oprets. malntaln, and monltor the posformance of the corrective neasure or nearures clected in the cus.

Attrched to this achorandu aro four docunerts davaloped by the offlce of Solld Heste and Emergency hoponse (OSWER) of the

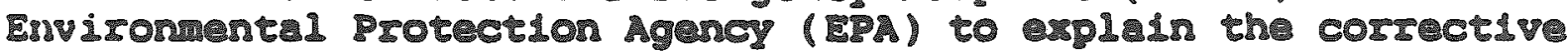
action program, and to asist FeA Reglonel officer and State regulatory ggenc1es with the developmant and implementation of corrective action orders under Saction $3008(\mathrm{~b})$. and perwt corrective action reguirenants under Sections $300 \mathrm{~A}(\mathrm{u})$ and (v) of RCRA.

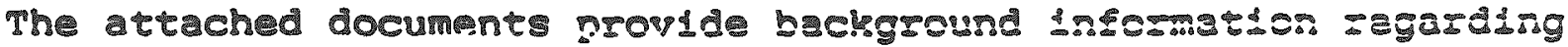
the FPA pollcies and gools pertaining to corrective action: specisy "model" reguirements for corrective action plans and consent orders: and provide guldance, a well as modol longuge, sor Interim mesures correctiv action orders. 
It is important to note that the "model language in all of the attached guldance materlals is generic and is intended only as a guide for preparing required documants. In "ral-world" situations, corrective action documents w11 be prepared on a ste-specific basis, taking into account special conditions or clrcunstances at the location for which corrective action is reguired.

These guldance material are bolng provided to you in order to assist you In more fully understanding the regulrements of the ERA correctlve acton program, a wall to provido IOu wh Insormation which way ald you in the cifectvo punning and implementation of the elements of corrective ation plans at your Ispectlve fac1l1t1es should they be regulred. The objectlve of corrective action plans. uhen they are Irgulied at DOE

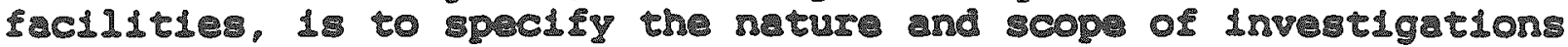
and corrective measures to bo aplied to tho cleanup of raleases of hazardous wates or hazardous constituents at treatent. storage, or disposal units rubject to Subpart C Of RCR following the steps outlined In the FPA corrective acton grogran.

In the Fall or Whater of 1989. FPA I expocted to propore the adition of now Subpart S. "Corrective Mction for Solld Werte

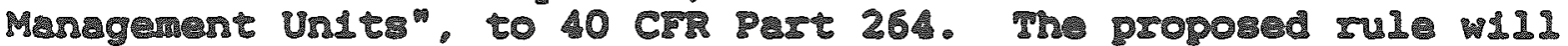

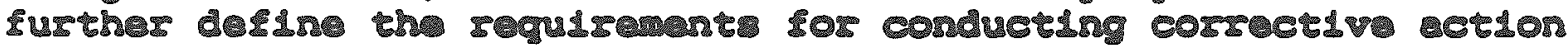

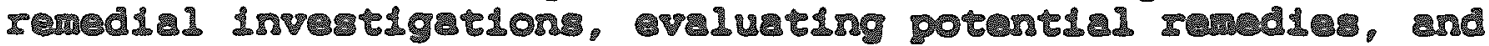

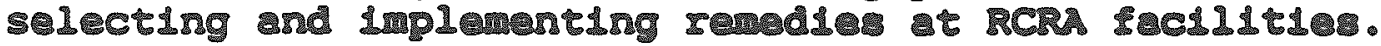

Even though esieting corroctive oction rogulrenats w11 bo anendod by the nev Subpart $S$ uhan It 18 prowigeted as a slnal Iule, the infornation contalned in the ttached guldance materials should continue to bo generally vald a guldance

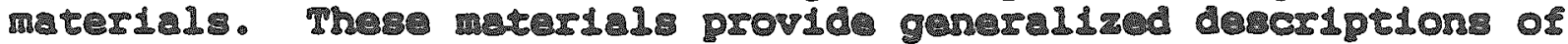

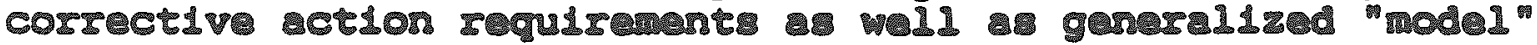
tochnical language which can bo uded gonoral guldance for the preparation of documents required as part of a correctiv acton plan.

Please note that once the new Subpart 5 regulremants are promulgated, Fi-231 w11 provide You with an update, if It 10 necessary of Insormeton regarding new or modisled regulraments

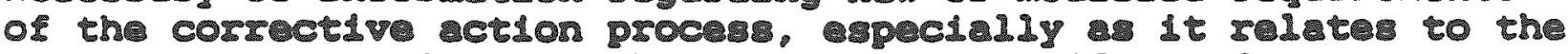
information contalned in the attached ERA guidance documents iescribed beiow.

ATtaChment 1 . RCR CORRECTIV ACTION PLAN: INFERIM FINAL. OSWER DIrect1ve 9902.3. The purpose of correct1ve acton plan (CAP) Is to assist regulatory authorlties in tho detarnination of the nature and estent of work that an onmes or oparator must persorm as part or a corrective action progran. 
Speciflcally, the CAP is used by the EPA and States In the developrent of corrective action osders under Section $3008(\mathrm{~h})$. and for defining corrective action requirements for permitted facildtier, Sections $3004(u)$ and $(v)$.

The CAP guldance document provldes "model langugge" which can be used to formulate jac1l1ty-speciflc scopes of work for the three most intensive phases (se igure 2) of corrective acton under RCRA. Thes oheres re (1): the RCRA Facdill Invertigation (RII). (2) Correctve Measures Study (CMS), and (3) the Corrective Meeures Implementetion (CMI). Rctul scoper of work for corrective ation activities ant bo tallored to mitespeciflc conditions.

It should bo noted that dIfferent typa na 1 ivels of corroctive

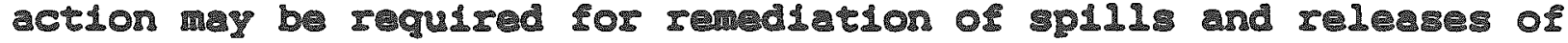

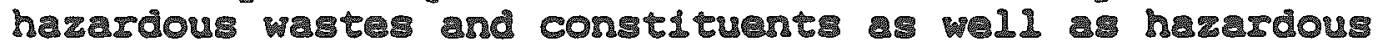

substances. Accordingly, the Informatlon provided In the CAP, as well as provided In the other guldance metridis described below. should be used for genersl guldance purposer only. Actul

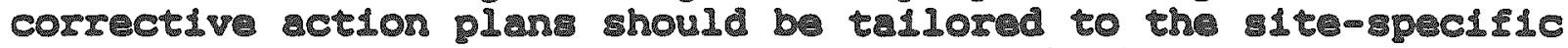

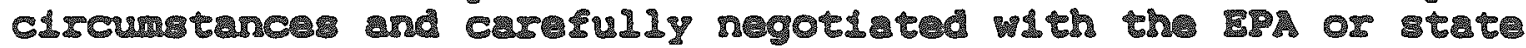
rogulatory authority when it hes corrective atlon authorlzatlon.

Attachant 2 . RCR CORECTIV ACHION INTERIM MERSURES GUIDANCE, OSWER DLIOCth 9902.4. Thl document prov1der a review of Interim mosures which na be lnolenented undar Section 3008(k), ar wl in and through RCN paralte. to gulckly addres enviromantal problem at 1 te uhd lo other detalled Investlgation are bing conducted.

The interlm mesures guldance inciuds an Interin nearure

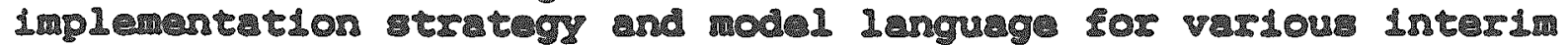
mearuse cton. Tha guldence liso contrin aodal languge for

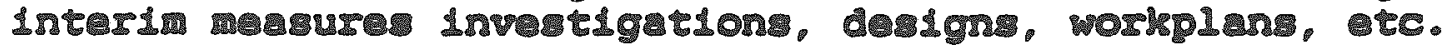

Attachment 3. INTERIM FINA RCRA SECTION 3008(h) MODEL CONSENT ORDER. The model consent order contelns generallzed language which mey be found in $3008(\mathrm{~h})$ conent osdars. Section $3008(\mathrm{~h})$ of

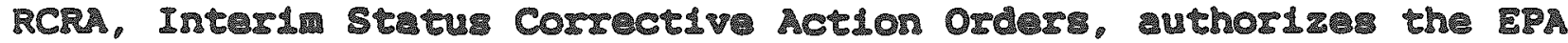
to Issue orders requiring corrective action. or take other appropriate response wasure to protect human helth and the enviroment, based on any information that there is or has been a

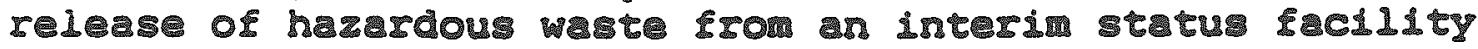
authordzed to operate under RCRA. 
In the case of tederal facilities. 3008(h) Orders for corrective action are issued by the EPA upon consent of the federal fac1lity involved. - Federal iacilities are given an opportunity to review and coment on, as well as negotiate with the EPA, the requiramests of the "Iinalized" order.

It should be noted If an agreement cannot be rached by EPA Regionel offlce and the DOE Facllity regarding the terms, condition, or schedules on an order, then dispute resolution orocess wil be Initiated and the dispute w1I be escalated to EPA Headquarters. The Office of Federal Activities (EPA), and/or the Leed EPA Headquarters progran ofslce, and the Dor

Headguarters w111 attempt to negotlate an ccoptable solution to the d1spute wIthin 90 days of the rafriral to rPA Hedguarters. If at the end of the 90 days, negotiations are t11 unsuccessful, then the dispute Is raferrad to the Administrator for resolution. If the dispute resolution proces is evoked, the proposed order will be stayed pending escalation and resolution of the dspute.

If federal facilities fall to rempond to proposed order within - specisied timerrame (usually 30 days), the order becomes a flnal administratlve order, efsectve at the tine establised in the proposed order.

Attachment 4 . NATIONAL RCRA CORRECTIV ACTION STRATEGY. The Strategy documint presents general overvin of the major statutory uthorlties for correctlv action. technlcal aspects of the corsectivo acton process. axd state-federal soles In implementing the national corrective actlon progran.

Quastons pertalning to the inforration provided herain or to RCR cosrective ction in grneral may be directod to Jersy Colgate of my stafs at Fis 586-6075.

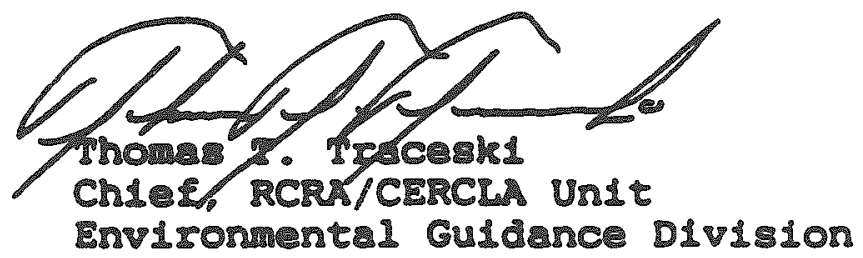

Attachments (4)

Figures (2) 


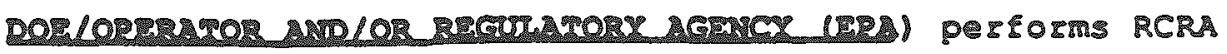

Eacility Assessmere (REA) TO:

RF

- Identify solid waste managenent units (SMMU) and collect misting information on contaminant releases.

- Identify relemses or suspected releases needing further investigation.

RTI

BEFTARO AGNCX specifies permi conditions or issues

enforcenar order to facility owner/operator to:

- Perform investigarions on releases of concern: and/or

- Implenent interin corrective measures.

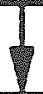

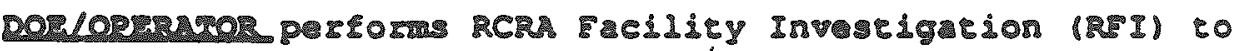
verify the release(s), if necessiry, no to characterize the rature, extent and rate of migration for zoleases of concern. Owner or operator reports resules and contacts the regularogy agency

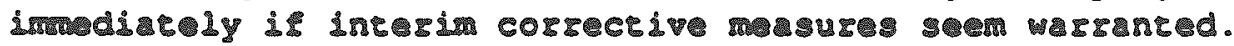

DONLOPERAR conducts Corrective Measures study (CMS) is directed by regulatory agency and proposes appropriate corrective measures.

RHCMn

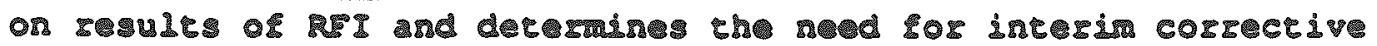
masuros, and/or coszoctive Measures study.

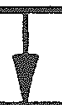

(n)

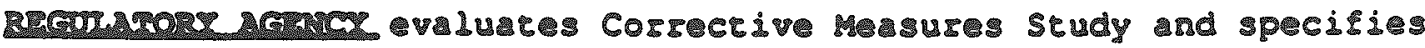
appropriare corrective measures.

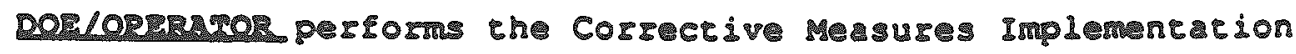

(CMI). This includes designing, constructing, operating.

maineaning and monitoring the cosrective measures.

Note: Although certin aspects of che Corrective Acrion Process are the responsibility of either the regulatory agency or Dorloperaror. closo coordination berwen the regulatory agency and Dor/Operator is essential throughour the process. 
APPENDIX C

Placement and Disposal

(Source: EPA CERCLA Orientation Course) 


\section{When Placement Does Occur}
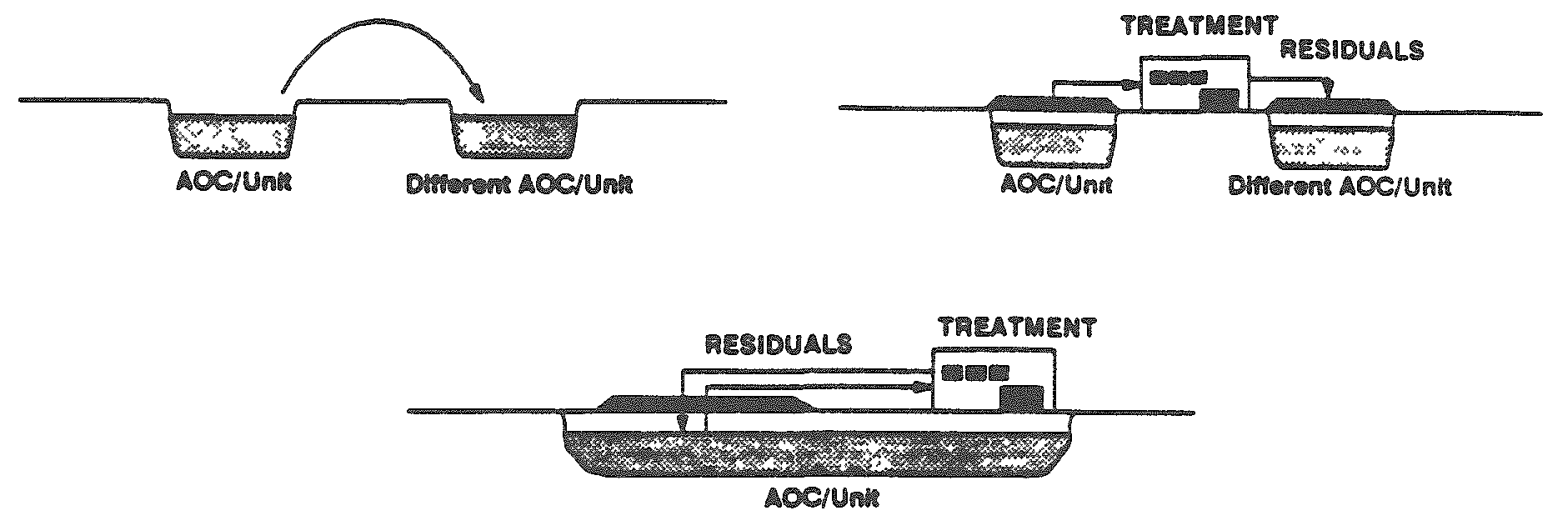

\section{When Placement Does Not Occur}
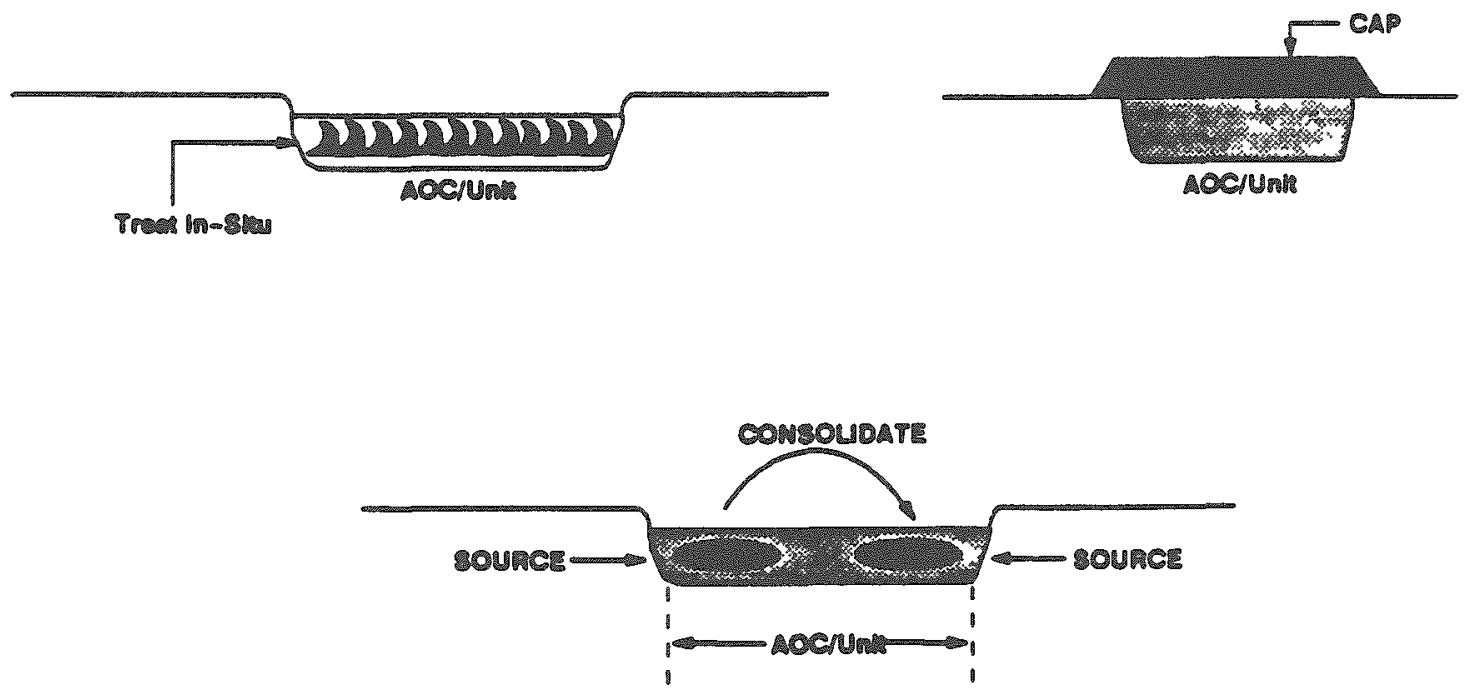

$C=1$ 


\begin{abstract}
APPENDIX D
Joint NRC-EPA Guidance on Conceptual Design of Radioactive Mixed Waste Management Unit Closures

Conceptual Design Exhibits
\end{abstract}

(Source: EPA Mixed Waste Training Course) 


\section{ALG $3 \quad 1987$}

TO THE STATES, COMPACT REGiONS. ANO ALL MRC LICENSEES

SUBJECT: JOINT MRC-EPA GUIDANCE ON A CONCEPTUAL OESIGN APPROACH FOR COMAMRCIAL MIXED LOW-LEVEL RADOAACTIVE AMO HAZARDOUS MASTE OISPOSAL PACILITIES

Under the Resource Conservation and Recovery Act (RCR), the U.S. Environmental Protection Agency (EPA) has jurisdletion over the mangement of solid wastas

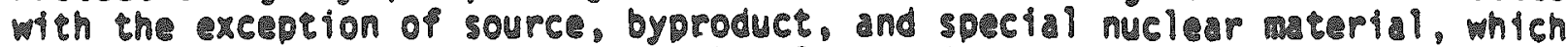
are regulated oy the U.S. Muclear Regulatory Contssion (MAC) under the Atomic Energy Ace (ACA). Low-bevel Radioactive Hastes (LLW) contain source. byproduct. or special nuciear meterials. but they ma also contain chemical constltuents wich are hazardous under EPA regulations promigated under Subtitle $C$ of ICRA. Such wastes are comonly referred to as Mixed Lom-level Radioactive and Hazardous Haste (MIxed LbH).

Applicable MhC regulatlons control the byproduct, source, and special nuclear matertal components of the Mixed LLW (10 CPR Parts 30, 40,61, and 70): EPA regulations conerol the hazardous comonent of the Mixed LLY 140 CPV Papts 260-266. 268 and 270). Thus. II of the individual constituents of Mixed LLW are subject to either MRC or EPA regulations. However. when the components are contined to become Mixed LLH. nelther agency has exclusive jurisdiction under current Federal Iaw. This hes resulted in dual ragulation of Hixed LLH where MRC regulates the radioactive component and EPA regulates the hazardous component of the same waste.

The atcached guidance document provides concepcul design approach for Mixcd LLW disposal facilities. It has been developed jointy by the MRC and EPA to assist comereial LLH disposal sice operators and State and Regional Compact regulatory agencies in designing disposal Pacllities that satisfy both cPA and NRC regulations for mixed LLW Facilities. Although BPA is currently in the process of promigating regulations that further define the technical parameters for the leak detection. leachate collection. and double liner systems. affected parties my proceed to develop designs for disposal units that will acceos Mixed LbH in accordance with existing requlacory requirements. Owners and operacops should, however, keep abreast of developing EPA regulations in this area. The atcrehed guidance is based on NRC and EPA regulations in epfect on August 1.1987.

The recached guidance presents conceptul design approach that meers EPA's regulations covering minimum technology requirements for liners and leachate collection systews. and MRC's pequirenents for minimization of contact of waste with water. While iso assuping long-tem stablitiy and avoidance of long-cem maincenance wich are required by both agencies. The concepts proposed in this documence are presented as general guidance: specific design deceils are expected to be complementary to particular site conditions. so that licerse application will have to adpess site characteristics and their relacionship to a poposed design as whll as the detcils of any engineered portion of the pactity. The apolication of this guidance will not affect the reauipenents for wase disposal fachilites to comply with 11 coplicable MRC and EPA regulaton.

D. 1 
The attached guldane should pemit licensees to develop safe and effective designs for disposal of Mixed blW that fully meet the regulatory requirements of both genctes. Depending on the particular type of conceptual design selected by licensee. EPA may permit variances to the pequirments for double iners and leachate coliection systems.

sincerely.
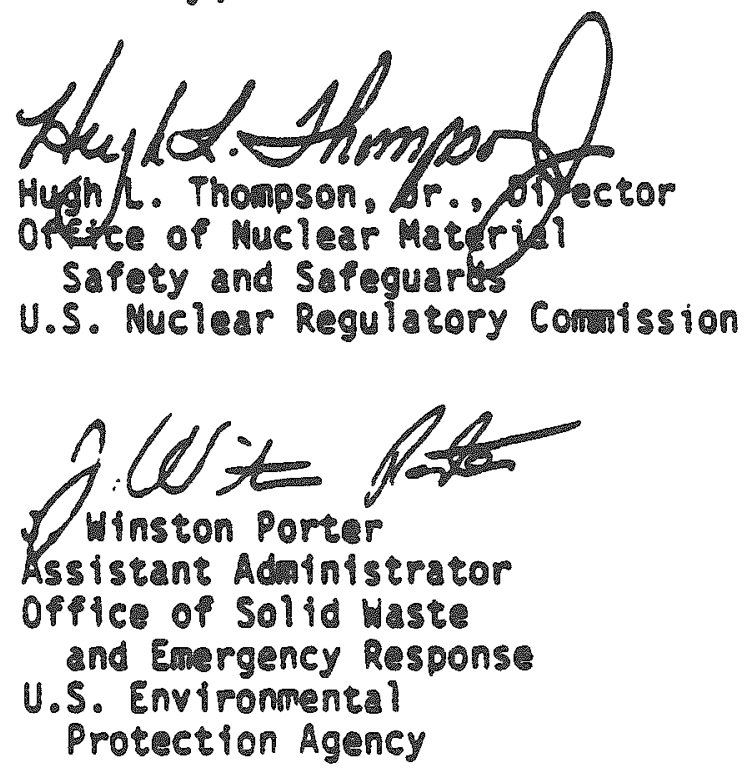

Enclosure:

As stated 


\begin{abstract}
JOINT MRC-EPA GUIOANCE OM A CONCEPTUAL DESIGN APPROACH FOR COMAERCIAL MIXED LOW -LEVEL RADIOACTIVE AND HAZARDOUS WASTE DISPOSAL FACILITIES
\end{abstract}

\title{
introduction
}

The Lom-Level Radorctiv Haste Pollcy Amendement Act of 1905 (LLRHPAA)

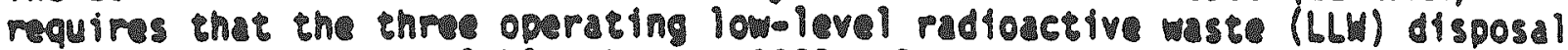

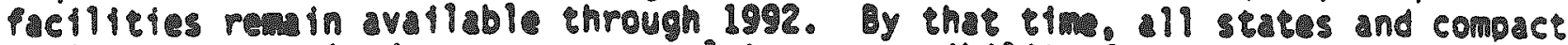
regions are peoulred to asume complete responslbility for bu disposil. Both

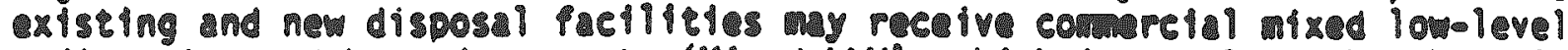
radioactive and hazardous wate (MIned LLV). wich Is regulated by the U.S. Muclear Regulatory Comatssion (MRC) under the Acomte Rnorgy ACt (ACA). and by the U.S. Fnvironatel Protection Agency (EPA) under th Rescupce Conservation

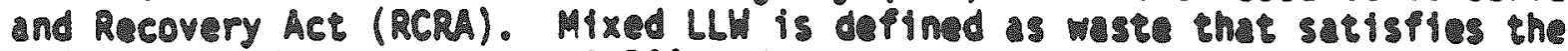

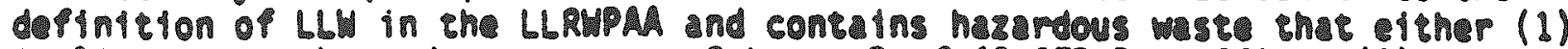
is listed as hazardous waste in Subpart 0 of 40 CPR Part 261 or (2) causes the LLW $c 0$ exhibit any of the hazardous wase charactartstics idantfied in

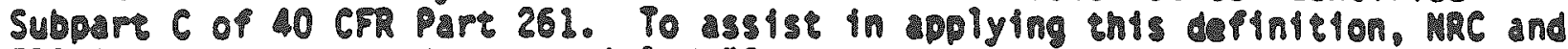
EPA Issued Jolnt guldance eneltled Guldance on the Da inicion and Identification of Comerelal Mined Low-Levl Radonctiv Haste and Answers co Antrelpated Questions" on Januery 8.1987.

This jointly developed MRC-EPh guidmen documen presents conceptul design approach that neets the regulatory requirements of both geneies for the safe disposal of Mix LLW. Other designs. or variteion of th proposed design concept my 150 be acceptable under the requirements or both ageneies and wili be reviewed on case-by-case basis as pecrived.

EPA regulations in 40 CFM Part 264, Standards for Owners and Operacors of Hacardous Waste Treatnent. Storage and 0isposal Facllities. identify the design and opereting requircments for cuners and operators thas dispcse of hazapdous ste in land 111 Is [264.300 40 264.317]. These regulations involve requiraments for the installation of two or more liners and leachate collection and removal system (LCRS) bove and between the liners to protect human health and the covironment. Exceplons co the couble liner and leachate

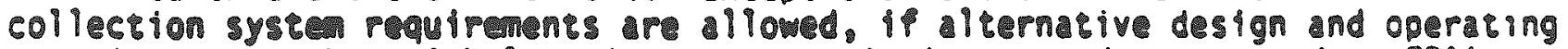
practices. togeher wh location charecterlstics. are demonstrated to EPA's Regional Adalnistracor to be caully ifective in preventh the migration of any hazardous constituent into the grounc ter or surpace water.

NRC regulations in 10 CPR Part 1 . blcensing Requirements for Land Disposal of Radioctive Haste. Indicate that long-term stablity of the waste and the disposil sle pequipe minimizction of access of ter to the waste [6l.7(b)(2)? and that the disposal site mus be designed to minimize to the extent prectlcabis. the contse of water with waste duping storage. the contact of standing water with whe duping disposal. and the contact of picolating op standing water th wastes frer disposel [61.51(3)(6)j. The orimary cbjective of the above MRC regulations ts to preclude the Dosslolitiy of che development of "bath-cub" efpet in which the waste could becone imarsed in liouid 
(..9. Prom inflitretion of surface water runoff) within a disposal unit below grade with low-pentability botcon surface.

The guidence on conceptual design approseh that is opfered in the subsequent paragraphs is intended to present basic design concepts that are acceptable in addressing the regulations of both the MRC and EPA with respect to requirenents for liners, leachace collection syseems and efforts to miniwize the contact of liquid with the maste. It should be recogniged that the guidance is bing provided at the conceptual level and that the design and detalls that are complementary to spectfic site conditions ned to be engineered by potential waste Pactility owneps. and operators. The application of the guidance in this document will not affect the reguipentent for licensees of waste disposil factitites to comply th all applicable MRC and EPA regulations.

\section{Conceptual Deston}

Sketches and brief discussion of the destgn considerabtons for an above orade disposal unit are provided. This design coneept has been developed prfanily to demonstrate the integration of EPA's regulatory regulreants for two or more iners and leachete colliction system above and between limers and the regulations of the MRC that require the centact of weter with the weste be minimized. In addition. the design concept Pulfill's the need under borh agencies" regulations to assure long-term stabiligy and winifalce active mintenance after slte closure.

In this approach. the Mixed LLW would be placed above the original ground surface in a cumulus that would be blended into the disposal sits topography. Schemetic detalls of some of the principal design pertures of an above grade Mixed LLbi tisposal unit are provided in the sketches accompanying this guidance document. Figure I depicts the three dimensional overall view of a conceptual Mixed LLW disposal unit: Figure 2 provides detalls of the peringter berw. liners, and leschate collection system: Figure 3 presents a cross-sectional view of the covered portion of the disposal unit: and Figure 4 describes the final cover system.

In the overall view of the Mixed LW disposal facility. the double liners and leachate collection and removal systen are installed before the emplacement of the Mixed LLW: and the cover systew is added closure. The leak detection tank and leachate collection tank are eneipcled by berm that controls surface water runof pro preclaitatton that would fall difectly on the waste facility site. The drainage plpes in the upper primary collection system would collect any leachate that could possibly develoo bove the cop piexible memorane liner and below the enplaced waste. Any leachate collected would dratn through the pipes to the primary leachate coliection eank where the leachate would be tested and treated, if required. Any leachate collected by the lower leachate collection and removal system would drain to the leat decection tant. The development of signtfleant amounts of leachate prom the solidipied waste after closure is not anticipated. This is because the clesure requirenants provide that the cover must be designed and constructed 1) to provide long-term minimization of watep infiltration into the closed disposal pacility. 2) to Puncetion with minimum mineenance, 3) to promote dranage and minimize erosion, 
and 4) to have a permebllity less than op cquil to the pemeability of any betcon liner system. It is anticipaced that the area shown on figure 3 between the slope of the find cover and the run-on control berin, where the canks are locased. would be regraded and the canks renoved at the and of the post-closure care period (nomally 30 years) when leachate developmen and collection is no longer a problem.

Figure 2 provides the general detalls required by EPh regulations for the double liner and leachate collection and removal system. The perimeter benm for leachate runoft control would assure that 11 leachere is collected below che wste and salely contrined and transported through the drainage layers and pipes to the tanks located outside the final covar slope. Me's regulations requiring minimizing contact of the waste with water are pulfllied by requiring the waste to be placed above the level of the highest water table pluetur and above the dranage layers were lechase would collect. The botco - levetion of the solidified Mixed HLW would be required in all instances bo be at levetions above the top of the perfinter berw.

In Figures 3 and 4 , the design concepts for the find cover over the solidifted waste zone and the perimeter berm are presented. The netull 20 ne for placement of solidified Mixed LLH may consist of difrerent options. depending on the 'icensee's selection. Options that would be accenteble include use of stable hioh integrity wasce contalners (HICs) thas have the spaces betwen containers filled with a cohesioniess. low compressible flll waterlal or placenene of the waste in an enginsered structure. such as reinforced conerate vault. A cover system over the waste that would be acceptable to the EPA and NhC is shown in Figure 4 . The cover systen would consist of (1) an outer rock op vegetative layer to minimize erosion and provide for long-tem stability. (2) a filter and drainage layer that transmits imflitrating water off of the underiying low perimability layers. (3) an impervious flextble membrane ilner overlying compacted low permeablity clay layer. ind (4) fllter and drainage iayer beneath the compacted clay layer. If ne solidified waste zone does not consist of an engineered vaule structure with top roor. an additional compacted clay layer should be placed imediately above the molaced waste to direct any water inilitration away frow the waste zone Mixed LLW that concains Class C waste as designated by MRC'S regulations would need to provide supficien thichness of cover materlals or an engineered intruder barrier to ensure the required procecticn gatnst induertent intrusion.

Variations on the above descrtbed design approach may include placenent of the Mixed bLH in an englneered reinforced concrare vaule. stel flber polymeroimpregnaced conerece vaule, or double-lined high incegrity concainers that are hemetically sealed. If proposed by license applicants. these variacions would be reviewed by both the EPA and MRC on a cascoby-case basis co evaluate their acceptability and conformence with established Pederal

regulacions. 
For questions related to NRC regulations and design requirements, contact:

Or. Sher Bahadur, Project Manager

Olviston of Low-Level Wast Management and Decomissioning

Mail Stop 623-5s

U.S. Nuclear Regulatory Comission

Weshington. DC 20555

Facility specific questions, permitting requirements, variances and other related concerns should be addressed to lither the EPA Reglonal office or State ageney authorlied to administer the mixed wasto progrem as appropriate. For general questions related to EPA regulations and design requireaents. contact:

Mr. Kenneth Skathn, Senfor Engineer

Waste Managenent Oivision

Mall Stop WH-565E

U.S. Environmental Protection Agency

401 M Street. SW

Weshington. OC 20460 


\section{TECHNICAL PROCESS REQUIREMENTS:}

\section{DISPOSAL}


PERMTTTNG MLED WASTE FACUUTES - DISPOSAL

\section{NRC Licenses for Disposal}

- Source, by-product, and special nuclear mateplal licenses may allow for disposal:

- On-site, if disposal process is approved by NRC, or

- Into sanitary sewerage system, if the waste meete cortain criteria

- Waste thet meets certain quantity and type specifications may be disposed of without regard to its radioactivity

- Disposal of low-level redioactive waste recoived from other persons (i.e.s commercial disposal) requires a separate disposal license

- On-site disposal is allowed if disposal process is approved by NRC. [10 CFR 20.302]

- Licensee or applicant must submit an application for approval of the proposed disposal. The applicetion must include description of the licensed material, any other radioactive material involved, the proposed manner and condizions of disposal, an analysis and evaluation of pertinent information as to the environment, usage of ground and surface waters in the general area, the nature of othor potentially affected frelltiles, and the procedures to be observed to minimize the risk of unexpected or hazardous exposures.

- Disposal into a cantary sewerage system is allowed, it the waste is readily soluble or dispersible in water and meets specific quantity limitations. [10 CFR 20.303] 
PERMTTNG MIXED WASTE FACIUTUES - DISPOSAL

\section{Irpical NRC Disposel Practice}

- Near surface disposal involves disposal into the upparmost portion of the earth (i.es, within approximately 30 meters of the surface)

- High-integrty containers can be used

- Design and operating requirements minimize migration of rediological contamination 
PERMMTTNG MLXED WASTE FACILTIES - DISPOSAL

\section{Obiectives}

- NRC - Water contact with radionctive waste should be minimized

- EPA. Contaminants should not leach from the unit

- NRC emphasizes the prevention of enterance of liquids into the unit.

- EPA emphasizes the prevention of release of hazardous constituents from the unit. 


\section{CONCEPTUAL DESIGN OF A MIXED WASTE DISPOSAL FACILITY}

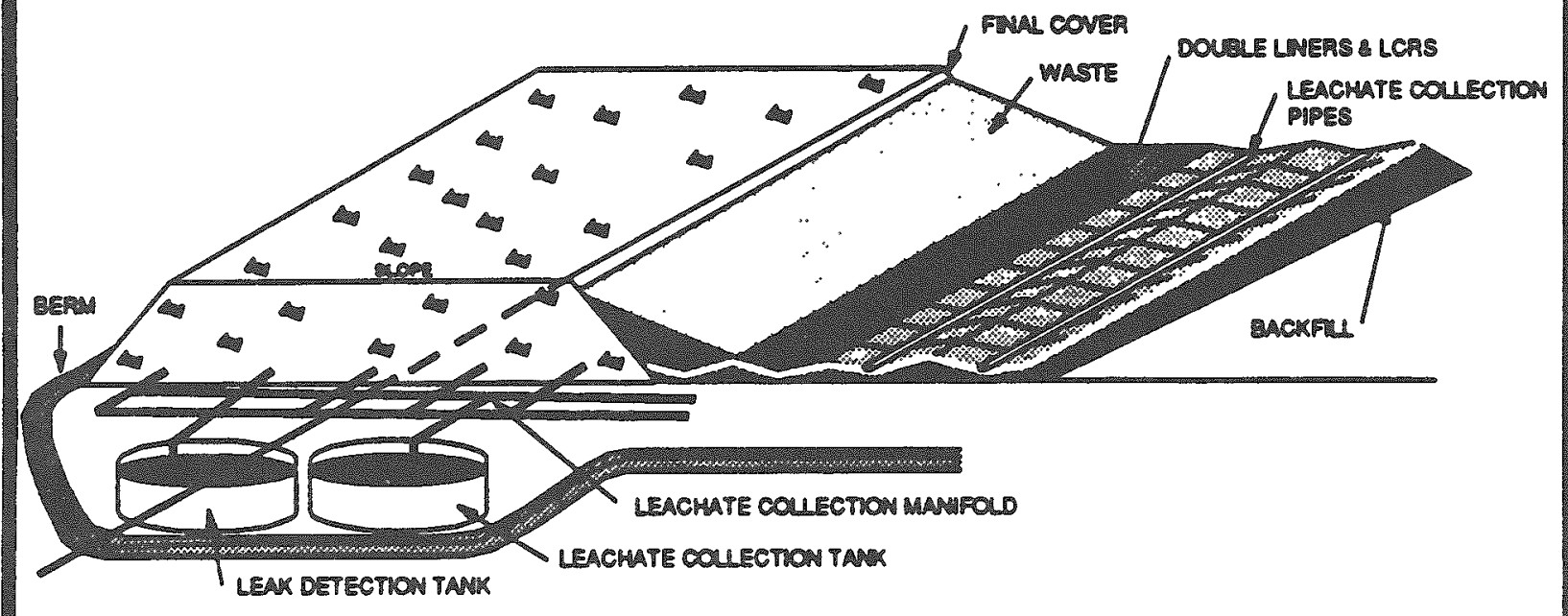

Slide No. 195

- The conceptual design of mixed waste disposal facilly requires that mixed lowlevel waste be placed above the original ground surface in tumulus and blended Into topography. The conceptual design integrates two liners and leachate collection system and minimizes contact between waste and water. The design also assures long-term stability while minimizing the need for active maintenance after site closure. 
PERIITTNG MTEO WASTE FACIITES - DASPOSAL

\section{Liners}

- NPC regulations do not specily liner roguiroments

- NRC regulations do not spocty leachete collection and renoval requiroments

- Emphasis 18 on Aliminating infltretion of lquide into the unit

- Caution must be taken to prevent abathtub efrect" Prom the use of RCRA liners in mixed waste units whereby the waste could become immersed in water within the disposal unit due to low parmeablity bottom surfice.

- RCRA systems for leachete collection and romoval must be installed above and between double liners.

- MFC emphasizes alminating the Infittration of liquids into the unit to create a passively protective system where the need for active maintenance is minimized. 
PERMTTING MDED WASTE FACIUTEES - DISPOSAL

Consideration:

- EPA and NRC design and operating requiremente are based on different objectives

- Incorporating both sets of objectives into one racilty may be difficult 
Options to resolve difterences:

- Excoptions to EPA's double linor and locchete collection aystem requirements allowed

- Aternate design and operating piactices, and

- Location characteristice are demonstrated to the Regional

Administretor's setistertaction

- Altemetves are to be demonstrated to the Regional Administrator to be equally effective in proventing the migration of any hazardous consthuents into the

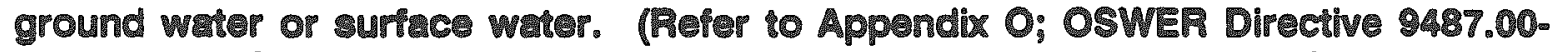
8: Joint NRC.EPA Guidance on Conceptul Desion Aporosch for Commercial Mixed Low-Level Radioactive and Hazerdous Waste Disposal Facilitios, August 3 , 1987.)

- Also see Appondx P; OSWER Directwe 9480.00-14: Combined NAC/EPA Suing Cuidelnes for Disposal of Commercial Mired Low-Lovel Radioactivo and Hazardous Waste, June, 1987. 


\section{CONCEPTUAL DESIGN OF DOUBLE LINER AND LEACHATE COLLECTION SYSTEM AT A MIXED WASTE DISPOSAL FACILITY}

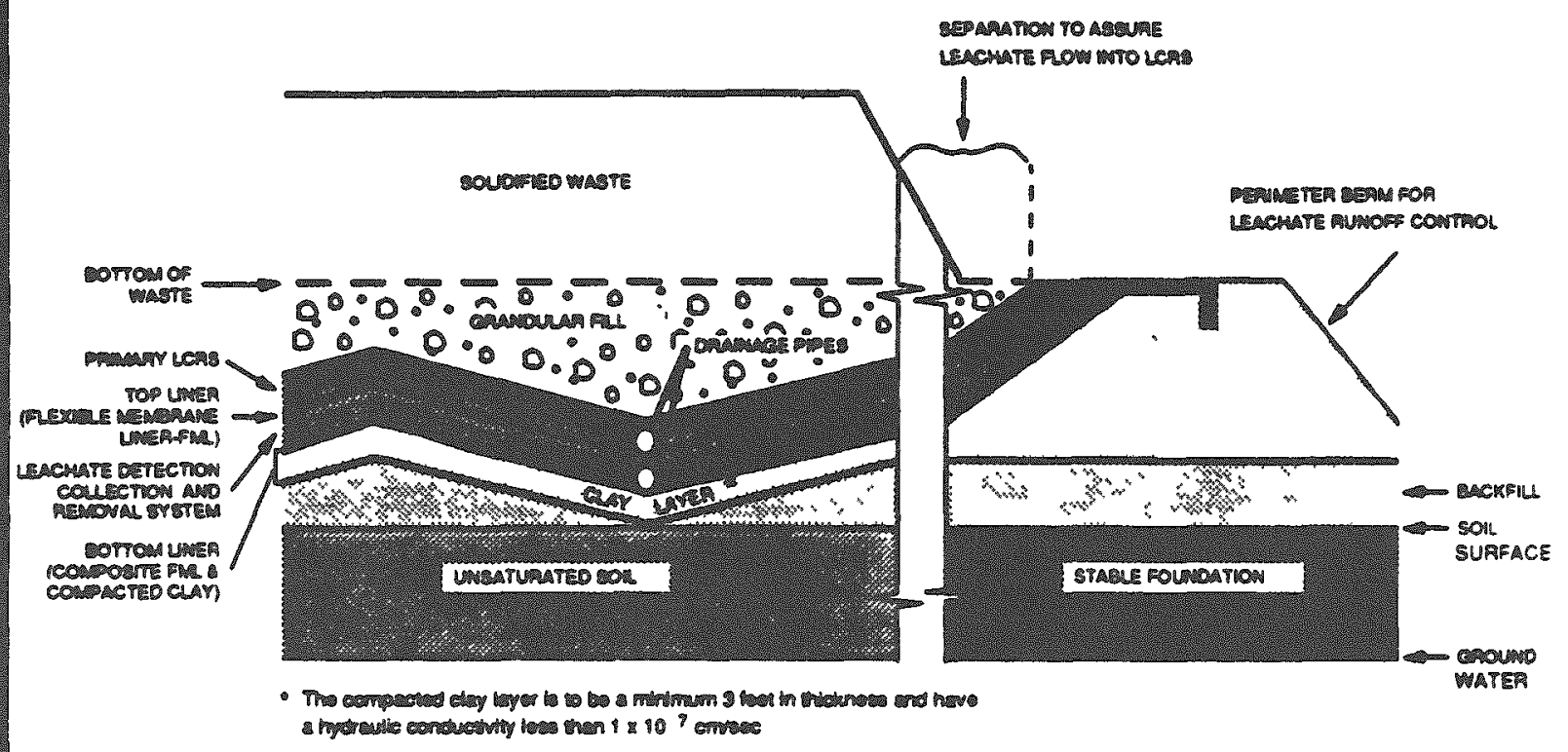

Slide No. 199

- Perimeter berm for leachate runofi control asures that leachate is collected below waste. In addtion, the botom devation of solidified waste is required to be above top of perineter berm.

- Using this design for double liner and leachate collection system will satisty the NRC requirement to minimize contect of weste with water is Iulfilled. 
PERMTTING MMED MASTE FACLTIES - DSPOSAL

\section{Covers}

- MRC covers must limit the radiation dose rate ex the surfece of the cover

- Mued waste containing Class C waste must bo under cover of sufficient thickness to protect gainst inedvertent intrusion

Slide Mo. 200

- NRC regulations (10 CFR 61.52) specty that waste must be pleced and covered in manner thet linte the redlution dose rate the the threce of the cover to levols that at minimum will pormis the licensec to comply whth the provisions of 10 CFR 20.105.

- 10 CRR 20.105 spectries the permissible levels of redietion in unrestricted areas.

- Both NRC and EPA covers are dosigned to:

- Minimize intrttretion.

- Promote dranage,

- Minimizerosion, and

- Require minimum maintonance. D. 16 


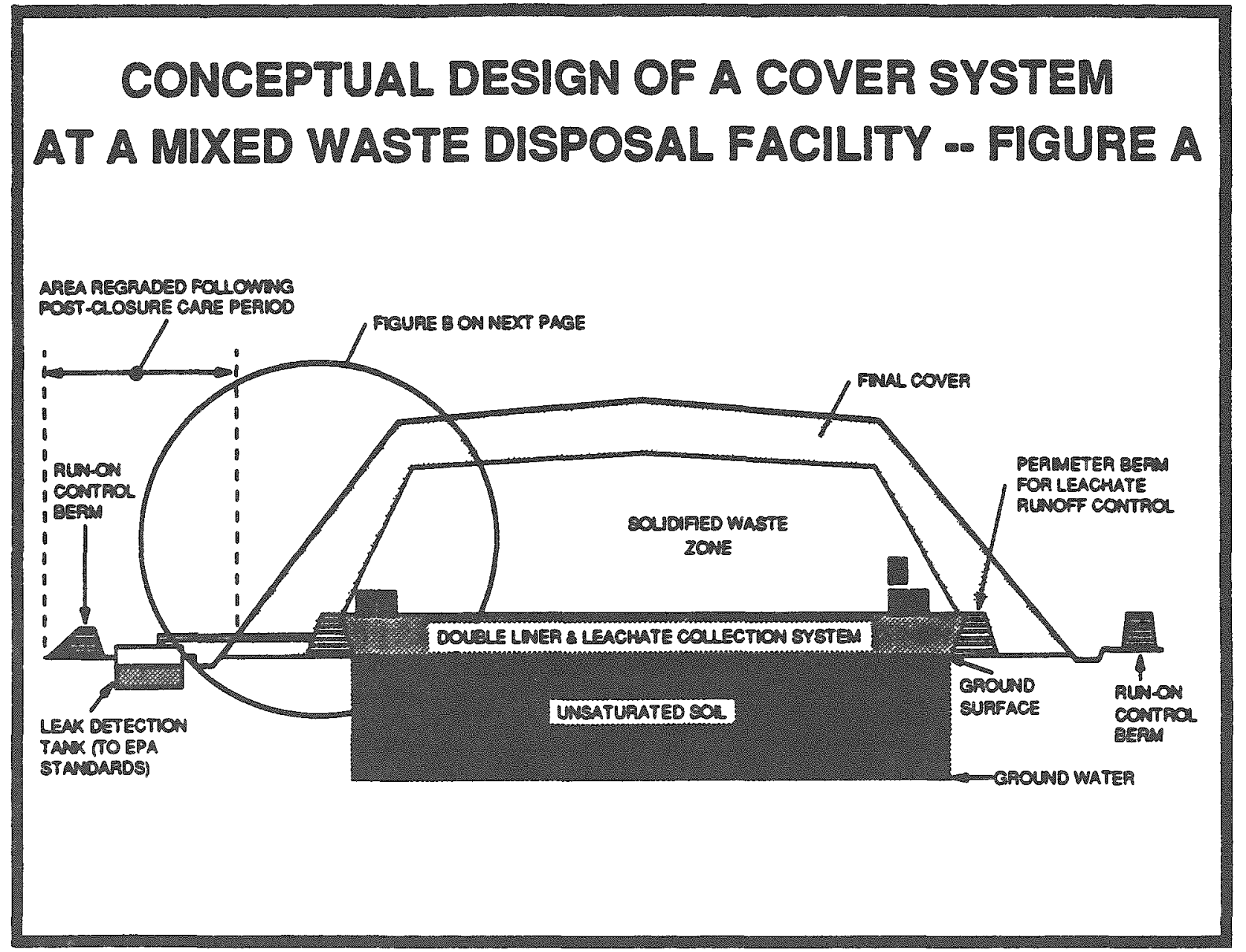

Slide No. 201

- Additional compacted clay liner should be placed immediately above emplaced waste if solidified waste zone does not consist of engineered vaut structure with a top roof. 


\section{CONCEPTUAL DESIGN OF A COVER SYSTEM AT A MIXED WASTE DISPOSAL FACILITY - FIGURE B}

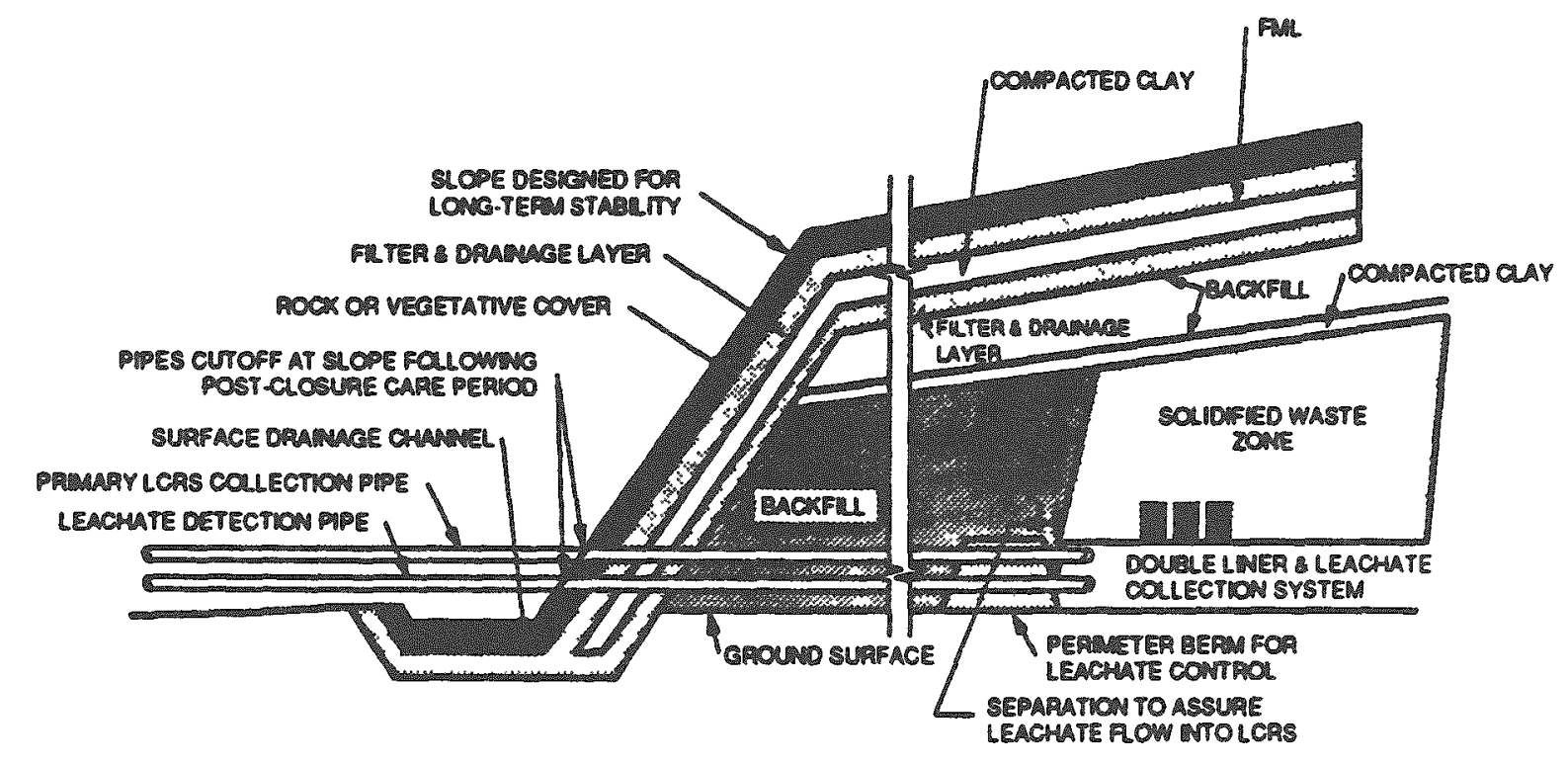

Slide Mo. 202

- Conceptual design of cover aymtem a mixed waste disposal facilty consists ำ:

- An outer rock or vegetative layor,

- A fiter and drainage layer to transmin infiltreting water.

- An impervious llexible membrane liner (FML) overlying clay liner, and

- A filter and drainage layer boneath the clay liner. 


\section{APPENDIX E}

DOE and EPA Memoranda on LDRs and Ground-Water Treatment Reinjections 


\section{memorandum}

DATE MAR 281990

REPLY TO

ATN OF EH- 231

SURJECT

Applicability of Land Disposal Restrictions to RCRA and CERCLA Ground Water Treatment Reinjections

Distribution

\section{Background}

The purpose of this memorandum is to provide Field Organizations with information and guidance on the applicablitty of Land Disposal Restrictions (LDR) to the reinjection of treated ground water into aquifers during "pump and treat" operations at Department of Energy (DOE) environmental restoration sites.

On December 15, 1989, the Environmental Guidance Division (EH231) issued a memorandum to all Program and operations offices entitled "Fact Sheets: Natural Resource Trusteeship Under CERCLA and Management of Contaminated Ground Water as Hazardous Waste". The fact sheet on ground water as hazardous waste described pertinent definitions and facts about the U.S. Environmental Protection Agency's (EPA) approach to managing contaminated ground water under the Resource Conservation and Recovery Act (RCRA). It also alerted readers that EPA's Office of Solid Waste and Emergency Response (OSWER) planned to issue an interpretive memorandum whlch would describe whether LDR applies to ground water that is reinjected during environmental restoration "pump and treat" operations. RCRA LDR may be applicable or relevant and appropriate requirements (ARARs) for certain response actions taken under the Comprehensive Environmental Response, Compensation and Liability ACt (CERCLA)".

The LDR Interpretation for reinjected ground water has been announced by EPA and is provided for your information at attachnent 1 (OSWER Directive 9234.1-06). Briefly stated, the EPA has determined that under certain circumstances, the LDR do not apply to reinjections of ground water during pump and treat operations. The driving force behind this action was a Department of Justice letter to the EPA asking for clarification of the applicability of the LDR to the injection of treated

\footnotetext{
The National Oil and Hazardous Substances Pollution Contingency Plan (NCP) reguires that CERCLA lead agencies comply with all applicable or relevant and appropriate requirements pertinent to the remedial action during the course of the action as well as upon its completion (55 ER 8666. March 8, 1990: to be codified at $40 \mathrm{CFR} 300.435(\mathrm{~b})(2)$. 
ground water back into the aguifer from which it was withdrawn at a Federal fac1lity. The EPA's LDR Interpretation for reinjected ground water is also consistent with a speciflc recommendation of a major EPA report. "A Management Review of the Superfund Program" (EH-231 distributed a synopsis for management on this report in a september 20, 1989, memorandum entitled "Fact Sheet: A Managenent Review of the Superfund Program: The 90-Day Report").

\section{Need for Interpretation}

In its management review of the superfund Program, EPA identified the misapplication of RCRA LDR (which are proscriptive regulations designed to prevent contamination before it happens). as contribut1ng to the inefficient implementation of CERCLA (a response program for respording to uncontrolled releases which have already resulted in contamination). There is recognition on the part of EPA that the problem of cleaning up large-scale contamination (under CERCLA) is quite different from the problem of how hazardous wastes should be properly managed by an ongoing operation (the focus of RCRA). EPA has Iacognized that in some cases, using RCRA standards as ARARs for CERCLA IEsponse actions confuses prevention for cure.

In genera1. RCRA IDR prohibit the land disposal of restricted wastes (after the effective date of the restriction), unless such waste meets promulgated treatment standards based on best demonstrated available technology (BDAT) Identified by EPA for that partlcular type of waste. Requiring compliance with these sundamentally "preventative" provisions of RCRA, could place unnecessary constraints on CERCLA response actions. The BDAT Iegimes can be difficult to apply at CERCLA sites because the wastes that are encountered are usually a mixture of different types of restricted wastes, non-restricted hazardous substances and debris, which may be dispersed throughout different environmental media. Each of the restricted wastes in a CERCLA mixture may require a different BDAT treatment. Since restricted wastes subject to LDR may be mised together with other restricted wastes, it can be dificult to determine the appropriate BDAT(s) for all of the restricted wastes in a CERCLA mixture 2 . These difficulties can be expected to be magnified at DOE's enviromental restoration sites, because there can be additional technical problems associated with DoE's soil and debris mixed wates, containing restrlcted hazardous wastes and radioactve wastes.

${ }^{2}$ In a September, 25, 1989, memorandum to Program and operations offices ent1tled "RCRA Land Disposal Restriction Guides for CERCIA Cleanup Actions". EH-231 provided a synopsis and copies of Sił ERA publications on the application of the RCRA LDR to CERCLA response actions. 
Because injection of ground water containing restricted wastes constitutes "Iand disposal" under RCRA section $3004(\mathrm{k})$, the guestion of whether the LDR are applicable to reinjected ground water during CERCLA "pump and treat" operations has been raised. If LDR are applicable, ground water containing restricted wastes would require treatment to attain standards based on BDAT prior to each reinjection. Since "pump and treat" remedies may have to operate for many years, the clean up action could become overly burdensome, technically impractical and/or prohibitively expensive.

The Applicability of LDR To Ground water Treatment Reinjection Interpretation at attachment 1 is one way EPA is attempting to correct the misapplicetion of the LDR to RCRA corrective and CERCLA response actions.

\section{Basis for the LDR Interpretation}

RCRA Section $3020(b)$ prohibits the injection of hazardous waste into or above an underground source of drinking water, with the following exception: the prohibition does not apply to "the injection of contaminated ground water into the aquifer from which it was withdrawn," if the injection is a CERCLA response action (Or a RCRA corrective action). the ground water has been treated to "substantially reduce hazardous constituents, "and the action will protect human health and the environment. The EPA Interpretation that LDR are not applicable to reinjection of treated ground water during RCRA Corrective and CERCLA response actions is based on the "traditional principle" that the more specific of two overlapping statutory provisions should control. In thls case, the language of the LDR, which refers generally to the land disposal of wastes, was found to be less specific than another RCRA provision [Section $3020(\mathrm{~b})$ ] that directly focuses on the injection of treated contaminated ground water into Class IV injection weIls (40 CFR $146.5(d))$.

In detemining whether RCRA LDR may be "relevant and appropriate" (for CERCLA response actions). EPA indicates that the requirement must address problems or situations similar to the circumstances of the response action contemplated, and be well-suited to the (CERCLA) site. Comparing the CERCLA response objectives with the purpose and objective of the LDR requirement is the key to EPA's interpretation of the potential relevance and appropriateness of the LDR to pump and treat operations conducted under a CERCLA response action. Treating and reinjecting ground water into Class IV injection wells is ultimately periormed to restore the ground water (aquiser) to drinkng water qualty. EPA believes that standards that have been specifically developed to establish. drinking water guality levels, such as Masimun Contaminant Levels (MCLS), are well-suited to the accomplishment of the CERCLA response action (i.e., pump and treat) objective. Thus, the EBA

$$
\mathbf{E}=3
$$


Interpretation provides that where drinking water standards are avallable (e.g., MCLs), those standards, and not the standards set by the LDR, will generally be the relevant and appropriate requirements to use in setting treatment standards for CERCLA response actions involving the clean up of drinking water aquifers.

\section{Necessary Conditions}

In order to reinject treated ground water during pump and treat operations at DOE's envirommental restoration sites without triggering the RCRA LDR, three conditions must be met:

1. the reinjection must be part of a CERCLA section 104 or 106 response action, or be a RCRA correctlve action.

2. the contaminated ground water must be treated to substantially reduce hazardous constituents prior to such injection, and

3. the response action or corrective action must be sufficient to protect human health and the environment upon completion.

Wh1le the language of RCRA section 3020 (b) is straightforward in its application to RCRA corrective actions, it is not expllcit with respect to CERCLA response actions conducted at Federal facilities. The Federal goverment is directed by Section 120 of the Superfund Amendments and Reauthorization Act (SARA) to comply with CERCLA to the same extent as private parties, so that a question arises as to the which statutory authority Federal facilitles employ for CERCLA response actions. DOE does employ CERCLA sect1on 104 authority consistent with the mandate of SARA section 120, consequentIy. DOE's CERCLA response actions satisfy the first condition. ${ }^{3}$

The second requirement of RCRA section $3020(\mathrm{~b})$ is that the reinjection must be treated to "substantially reduce hazardous constituents prior to such injection." There is no quantitative guidance available at this time which will provide environmental restoration managers with the certain knowledge that they have met this requirement. ERA suggests that the steps necessary to

'The basis fOI DOE's use of CERCLA section 104 is found in Esecut1ve Order 12580, "Superfund Implementation", Jan. 23, 1987, Sec. 2(d). by which the President delegated the President's removal and remedlal response authorlty under CERCLA $104(\mathrm{a})$ and remedy selection authority under 104(c)(4) to the secretaries of Defense and Energy with respect to releases or threats of releases from any vessel or faclilty under their control. provided that this authority is exercised ".. consistent with the requirements of Section 120 of the Act" (1.e. SARA Section 120). 
"substantially reduce" hazardous const1tuents during a RCRA correctlve action or CERCLA response action should be decided on a case-by-case basis until speciflc guidance is prepared on the issue. EM-231 will disseminate the EPA guidance to all Field Organizations once it becomes avallable.

As a final condition, the corrective action or response action must be sufflcient to protect human health and the environment upon completion. EPA's guidance on meeting this requirement is to consult RCRA and CERCLA statutes, Iegulations and policies. Pursuant to DOE Orders, RCRA correct1ve act1ons and CERCLA response actions undertaken by the Department are required to be protective of human health and the environment. When these actions are performed in compliance with the appropriate governing statute, regulation or pertinent guidance document. they may be presumed to be protective of human health and the environment upon completion because of the stringent protectiveness requirements and the regulatory oversight imposed by these procedures. The pertinent governing regulations which, if properly implemented. will confer the appropriate degree of protectiveness for human health and the environment such that this Ilnal condition will be satisfied, include: 1) the National Oll and Hezardous Substances Pollution Contingency Plan (for CERCLA actlons): 2) Standards for Owners and Operators of Hazardous Waste Treatment, Storage and Disposal Facilities ( 40 CFR 264. Subpart F): and 3) RCRA Corrective Action requirements, 40 CFR 264. Subpart S (when promulgated).

Field Organizatons are encouraged to consult with their Regional EPA Office on the proper application of the LDR interpretation for the reinjection of treated ground water into or above underground sources of drinking water (1.e.. into Class IV injection wells) at their facilities. If you have any questions about the attached Interpretation, please contact John Bascletto of my stat at FTS $896-7917$.

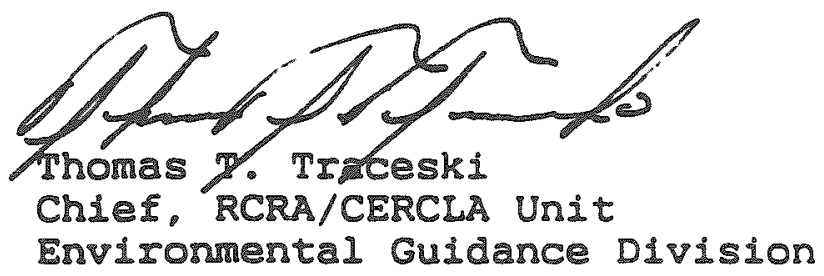

Attachment 


\section{DER 271090 \\ ofmes or \\ SOHO MASTE ANO BMEMGENCY MESPONSE \\ OSWER Directive $9234.1-06$}

MEMORANDUM

SIBJECT: ApPlicability of Land Disposal Restrictions to RCRA and CERCLA Ground Water Treatnent Reinjection Superfund Management Review: Recommendation No. 26

FROM: Don R. Clay. Assistant Administrator 0

TO: Waste Management Division Directors Regions $I-X$

Regional Counse 1

Regions I - X

\section{Purpose}

There has been some question as to whether ground watep contaminated with restricted RCRA hazardous wastes, which is extracted during a RCRA corrective actjon or CERCLA response action. must meet the best demonstrated arai laule techmolog: (BDAI' identified for that waste under thr RCKA land disposil restrictions (LDRs) prior to each reinjection, in a pump-ancl-tr.l reinjection remediation system. (See RCRR sections 3004 (1), (i) and (m), and 10 C.F.R. Parts 148 and 268.) THis memorandum explains EPA's interpretation of whether the LDRs are apnlicaulf or (under CERCLA response actions only) relevant and appropriat: to such reinjections or to the remediation as a whole.

\section{Backaround}

RCRA LDRs prohibit land disposal of restricted RCRA hararcou. waster that do not meet treatment standards after the effective date of the restrictions. Treatment. standards for RCRA hazarcucu wastes are based upon the best demonstrated available technolngy" (BDAT) identified for that waste. See 40 C.R.R. 268. Because placement of hazardous waste into underground injection wells constitutes land disposal under LDR (see RCRA section $3004(k)$ ). and the ground water undergoing reinjection may contain a restricted waste. the issue has been rajsed as to whether earh reinjection of contaminated ground water should meet BDAT durju: response or corsective actions.

$$
\mathrm{E}=6
$$




\section{RATIONAIE}

Ground Water restoration under RCRA corrective actions and CERCLA response actions often involves withdrawal, treatment or the contaninated water, and reinjection of the treated water into the ground. The land disposal restrictions (LDR) of the Resource Conservation and Recovery ACt (RCRA) prohibit land disposal of restricted RCRA hazardous wastes that do not meet treatment standards ater the effective date of the restrictions. Treatment standards for RCRA hazardous wastes are based upon the best denonstrated aval lable technology (BDAT) identiled for that waste. See 40 C.I.R. 268. Because placement of nazardous waste into underground injection wells constjtutes land disposal under IDR (see RCRA section $3004(\mathrm{k})$ ), and the ground water undergoing reinjection may contain a restricted waste. the issue has been raised as to whether each reinjection of contaminated ground water should meet BDAT during response or corrective actions.

Section 3020 Of RCRA [Previously section 7010² J specifically adoresses waste injection in the context of CERCLA and RCRA Cleanups. RCRA section $3020(a)$ bans hazardous waste disposal by underground injection into or above an underground source of arinking water (witnin one-guarter mile of the well). However. RCRA section 3020 (b) exempts from the ban all rejijections of treated contaminated ground water into such formations undertaken as part of a CERCLA section 104 or 106 response action, or a R'RA corrective action. To gualiy for the exemption, the collowing three conditions must be met: (1) the injection is a CERCLA response action or a RCRA corrective action. (2) the contaminated ground water must be treated to substantially reduce hazardous constituents prior to such injection, and (3) the response action or corrective action must be sufficient to protect human health and the environment upon completion.

Although RCRA section 3020 and the LDR provisions at RCRA sections $3004(f):(g)$ and $(\mathrm{m})$ arguably can address the same activity, RCRA section 3020 specíl一ady applies to all CERCLA and

1 CERCLA remedial actions are required to neet Federal requirements and standards at completion of the remedial action if the Federal standards are applicable or relevant and appropriate requirements (ARARs). absent invocarion of a statutory waiver. See CERCLA section 121(d). Agency policy and the proposed National Contingency Plan (NCP) require the Agency to comply with all ARARs pertinent to the action during the course of remedial action, as well as upon its completion. See the proposed NCP (published at 53 Fed. Reg. 51.394 (Dec. 21, 1988 ) (to be codified at 40 C.F.R. $300.435(b)(2))$, and CERch conoliance with other Laus Manual: Part I. I-8 lOSweR Directive number 9234.1-01. August 8. 19881.

2 RCRA section 3020 was section 7010 in the Hazardous and Solid Waste Amendments of 1984 , but was renumbered in 1986. 
RCRA gFound water treatment reinjections into Class IV injection we115. Consistent with traditional princigles of stetutory construction. RCR section 3020 - which is directly focused on injections of treated contaminated ground uater into cIass IV wells during cleanups - should be controlding for such injections: a contrary reading would render section $3020(\mathrm{~b})$ meaningless. Where congress has provided two potentially applicable statutory provisions. choice between then is both necessary and appropiate. and within the discretion of the expert agency. Accordingly. EPA construes the provisions of RCRA section 3020 to be applicable instead of LDR provisions at RCRA sections $3004(\xi),(g)$, and $(\pi)$, to reinjections of contaminated ground water into an underground source of drinking water (USDW), which are part of a CERCIA response action or RCRA corrective action.

As a result, the three conditions of RCRA section 3020 (b) must be net during response or corrective actions involving ground water treatment reinjection into or above underground sources of drinking water. Failure to meet these conditions bans. the activity under RCRA section 3020 (a). First, the injections must be part of a CERCLA response action or a RCRA Corrective action. Second. each reinjection has to be treated to substantially reduce hazardous constituents prior to such injection... (RCRA section $3020(b)$ ). Until guidance is prepared addressing the issue. steps necessary to "substantid Iy reduce" hazardous constituents during a RCRA corrective action or a CERCLA sesponse action should be decided on a case-by-case basis. Third. the response or corrective action upon completion must be suficient to protect human health and the environment" (RCRA section $3020(\mathrm{~b})$. RCRA and CERCLA statutes, regulations and policies should be reviewed to determine protectiveness.

The issue may also arise under CERCLA as to whether LDRs are relevant and appopriate reguirements when treated ground water is reinjected into Class IV wells as part of a CERCLA response action. In order to be considered to be both relevant and "appropriat" a reguirement must address problems or situations similar to the circumstances of the release or remedial action contemplated, and be weli-suited to the site. A key factor in determining the potential relevance and appropiateness of a

3 class IV injection wells are used to inject contaminated ground water into or above an underground source of drinking water. See 40 C.F.R. 146.5(d). In most situations, ground water treatment reinjection involves ondy Class IV injection weIIs because treated ground water is recharged back into an underground source of drinking water (USDW) during pump-and-trent activities, not beneath it. otner classes of wells are not subject to section $3020^{\circ} \mathrm{s}$ special provisions.

4 Note, however, that an ARARs waiver may be appropiare in certain cases for actions taren under CERCLA. 
requirement is to compare the CERCLA response objective with the purpose and objective of the reguirement. See crect Compliance with other Laws Manual at P. 1-65 (EPA. August 8, 1988): Proposed NCP, 53 IR at 51436 (DeC. 21, 1988) (proposed secrion $300.00(\mathrm{~g})(2))$.

The ultimate puspose of treating and reinjecting ground water into class IV wells is to restore the formation to drinking water guality. EPA believes that standards that have been specifically developed to establish drinking water quality levels Isuch as MCLs') are particularly weld-suited to the accomplishment of that purpose. Although LDRs aso prescribe treatment levels, those ievels were not specifically developed to achieve drinking water guality (although they may often have that result). Thus, where drinking water standards are available, the Agency believes that they will generally be the relevant and appropriate reguirement to use in setting treatment standards for CERCLA cleanups of drinking water formations.

In situations where no drinking water standard has been promulgated for the contaminants to be treated. the Region should consider potentially relevant and appopriate renuirements (including any available health-based standards. Lon treatnent standards, ttc.l and attain the standard, if any, that the Agency sinds is "relevant and appropriate under the circumstances of the. release (or justify a wiver).6 ERA guidance sets out a number of factors for deciding is a requirement is relevant and appropriate under the circumstances of the release. See CERCLA Compliance with other Laws Manual, at p. $1-67$.

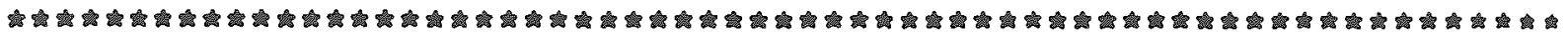

NOTICE: The policies set out in this nemorandum are intended

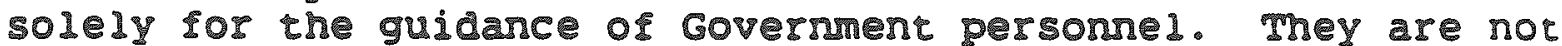
incended, nor can they be relied upon. co create any rights entaceble by any paty in ditigation with the united states.

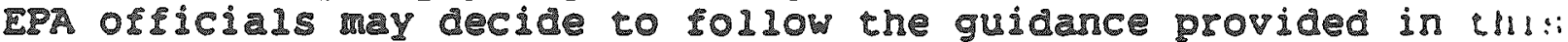
memosandum, os to act at variane uth che guidance, based on ni

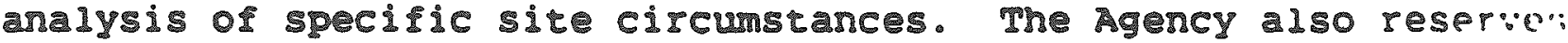
the ight 10 change knis guidance at any time uithout public ab1두.

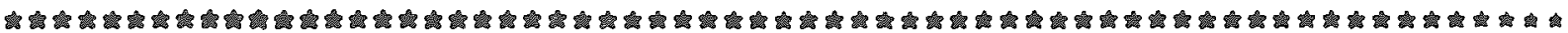

5 See the discussion of MCLs and MCLGS in the proposed an: 1.กล 1 NCP.

6 Is no such standards are relevant and appropiate. TBC:: mi; be used as cleanup levels; use of a TBC should be explained an! justiried for each specícic case. 
separate from the restrictions found in RCRA LDRs, an independent provision of the statute, RCRA section 3020 . bans nazardous waste injection into drinking water sormations (CIass IV injection ue11s), unless the conditions in subpart (b) are met. Subpart (b) permits reinjection of contaminated ground water that has been treated if: (I) the injection is a CERCLA response action or a RCRA corrective action. (2) the contaminated ground water is treated to substantially reafuce hazarous constituents prior to cach injection, and (3) the response action or corrective action is suricient to protect human health and the environment upon completion. (See RCRA section $3020(\mathrm{~b})$.)

\section{Resolution}

For the reasons specified in the attachment to this memorandum, LDR is not applicable to these activities. Instead of LDR, RCRA section 3020 applies to reinjection of treared contaminated ground water into Class IV injection wells during CERCLA response actions or RCRA corrective actions. Moreover. for CERCLA response actions where the goal is to clean up ground water to drinking water levels, the Agency believes that health-based drinking water standards (e.g. MCLs) - rather than IDRs - - will generally be the relevant and appropriate cleanup standard. See the attachment.

Until guidance addresses the issue, what is required to "substantially reduce" hazardous constituents prior to each injection in a CERCLA response action or RCRA corrective action should be determined on a case-by-case basis. RCRA and CERCLA progran policies and guidance should be reviewed to determine protectiveness upon completion of the action.

\section{Attachment}

CC: CERCLA and RCRA Branch Chiess

office of Drinking Water 


\section{APPENDIX F}

DOE Memorandum on Proposed RCRA Siting Restrictions 
DATE. MAR I 1989

คEด Y Y Y

ATTN OF $\mathrm{EH}-231$

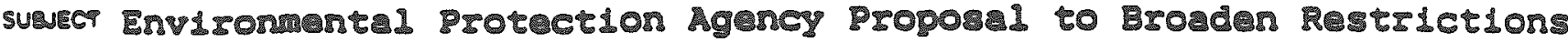

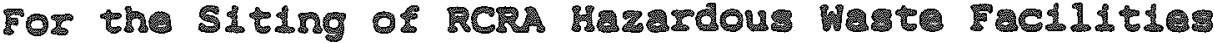

\section{1:tedbution}

Thlo 1 to 1nsorn you that the Fnvisonental Protecton Agency. op Out11ne of Porelble Subtltie C Location Standards). which could require the closure of esisting hezardous waste treatment, storage, and disposal unlts loceted in unatable terman. near certaln netured resource areas, or loceted abovo important aqu14ers.

Under thes now regulatlone, the conerructon or new hazardous

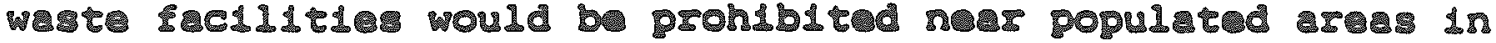
ordor to seduco human aspouro to hazardou wores, and new land-

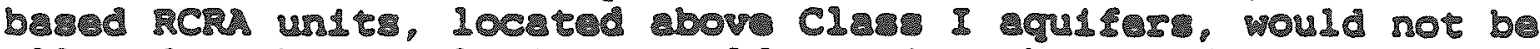
110wed. The regulation woule regulro the lnivilate clozure os aststng land-based unitr located above thase agulers.

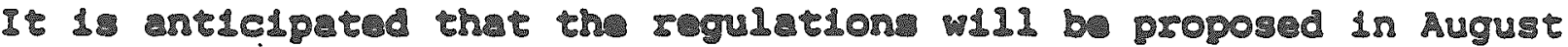
os September of 1989. uth Flnel rulo ant1cipatod by February.

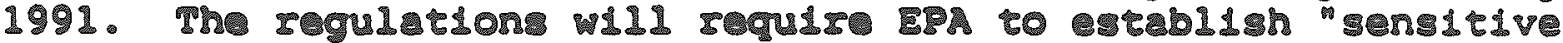
locetsone mhore:

* Now or arpanding 1and-band undte would be banned when the ground water cannt bo rcuratry charactrilzod or mondtored, or whare corroctive acton L "Inteasible

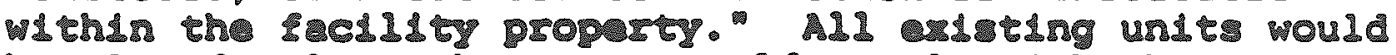
bo closed unlese the ourser could comply whth the standard tor na unt?. Land-bered undt includ

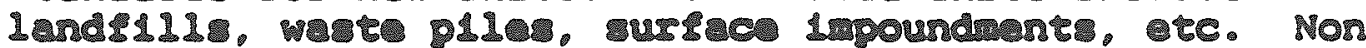
land-bared unt tould Inelude tants and concalners and ancildary ogulpiant.

* Tho contruction of no. or tho axparson of cristing land-baed untte 1 thin the 100-year floodpladn. or other area prone to ilooding. or whin sorner lake bedr.

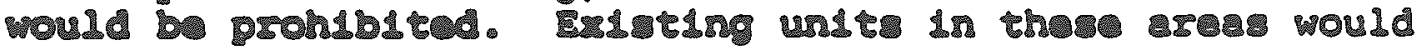
be required to clove. Onnore or other. mon-1and-baed

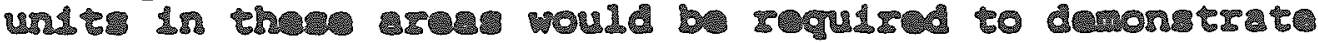
that they could prevent werhout. Unit rallisg tho cmonetritson would bo banned or clond. 
- Now or expanded units would be prohlbited In Karst

terralns or areas with soluble carbonate rock, unless the omer is ble to character120 the s1t''s hyarogoology and prove that there w11 be no subsuricee collopse and: demonstrate the ablity to mondtor ground water flow accurately at land-based units. Eisisting undts must meet the requirements for now units or close.

* Now hamardous waste un1ts, located within 200 seet of a sault at which there has bean an arthguak within the pert 10,000 years. would bo banned throughout the United states. The current ban on the stelng of nen undts in actve earthquke area aplie only to parts of Alaska. AILona, Colorado, Mawa11, Idaho. Montana, New Mex1Co. Utah, Washington, and Wyoming, as well as to all of Callfornil and Nevade. The ban on new undts nes active faults would be walved is the ownor could demonstrate that the units could withstand maximu horizontal acceleration and maxlmum velocity according to tho ofsice of Soldd Waste.

* Now unter in or ajacent to wotands would bo banned. Unter lready adjecont to wetand could not empand unless the omner obtaln armit undar Section 404 of tho clean Weter Act fron the U. S. Mruy Compo of inglness and demonetrates the tho und has susplc1ent "long-tarm integrit" to protact the norby resource. Finting undts that sal to demonstrete long-tarm Integrity and the cbllity to protect the celogr of the adjacent wetand would be closed.

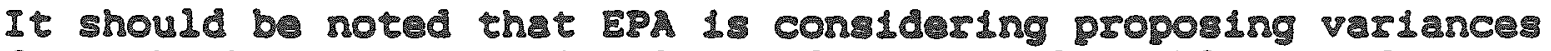
ז50n tho ban on now undts located above vunerablo aquifers and near human population conters. For Clase I agulier: the orice or Solld Wast would walve the ban on now land-based units and the closure of exdeting one 15 tho owner domonstretes that he W11 prov1de care byond the normal 30-yer post-closure care

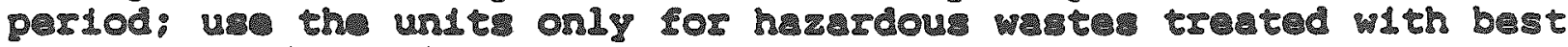
demonstrated avallable technology (BDAF): and onsure thet there 1s no threat to tho ground wer.

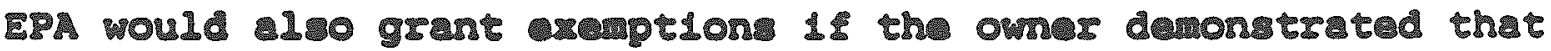
"corroctive actor could bo lmplamented csectivi"."

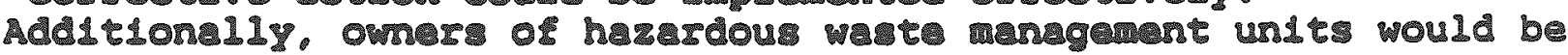
ablo to seok walver of tho ban on now undte near human

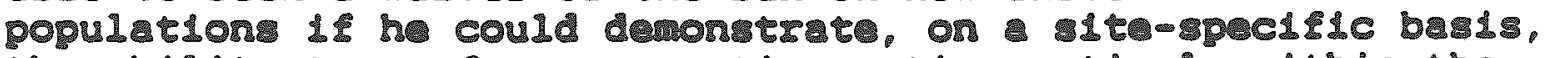
the blilty to perform corroctive acton antlroly within the

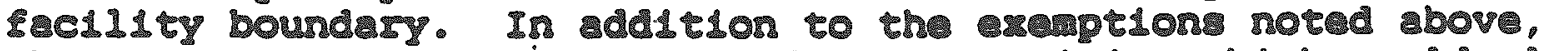
the Agency 1 considering including proviston whlch would allow

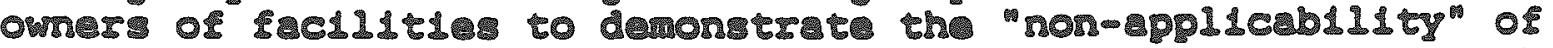
the Location standards by mean of a cortification stateuent by the owner. F. 2 
The rule would 150 require parmit mister to estabish sitespecille distancos between two units and the facility boundary to allow corrective action at each unit. ommers of existing facliltis thet sall to make the on-site cleanup demonstration would bo regulied to install additional protective measures to prevent releser of hazardour wastes from leaving the faclisty.

In add1tion, under this rule, ownes would heve to upgrade the15 contingency plans and emergency proceduras to control catestrophic raleases of hazardous substancos into the air.

If It 18 dotesmined that the rule dos apply to facllity. the owner wil have to decide whether to relocate a unt. or ensure that an existing unit, located in a sensitive environment, meets the required demonstrations. If the owner decides to close the un1t. he would be required to choose among the closure optsons based upon technical factors specill to the sensitive area.

Two closure options are belng considared by the EPA. The Agency may anend the cursent closure and postclosure rules in Subpart $G$ or Part 264 to add perormance standard por cloned unlts in

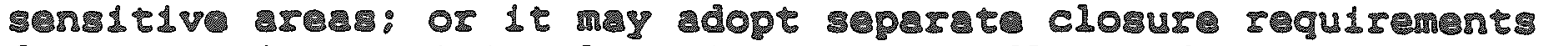
for units in senstelve locations. Regardlase of the option chosen. the Agency w11 cstabl1sh spec111c techndcal closure

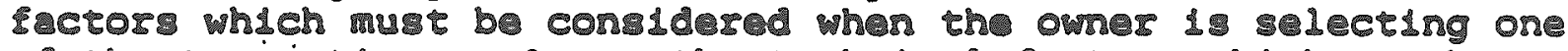
of tho two optlone. Among the cochnical Pactors which may bo cons1dered by ERA would bo str-specisle hazards. Including

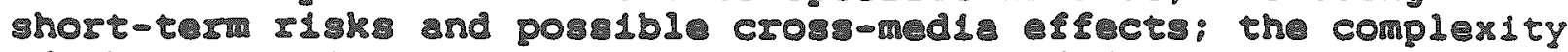
of tho waste in the unit: the probab1lity of ruture releases:

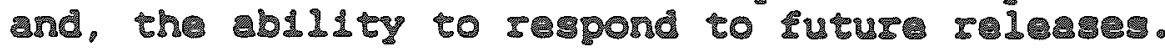

The proposed regulation would apply to all nev undts sis months

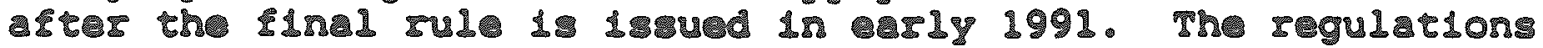
would apply to activ RCR undts at the the Pert permit is

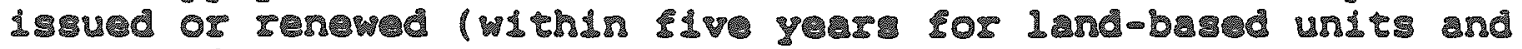
w1thin 10 years for all othar units). The rogulations would apply to 1nterin-stru undte when closure plan is appoved or a postclosure print 1sued.

These rogulatone. when promulgated, could havo igniflcant Impact on Do: oporatis throughout the United States. They could result in the cloruro of critrleal hazardous warte manegenan unter andor the provention of the construction of

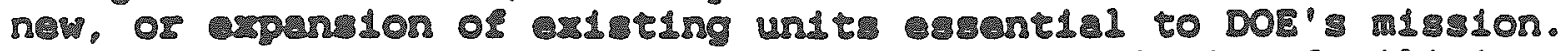

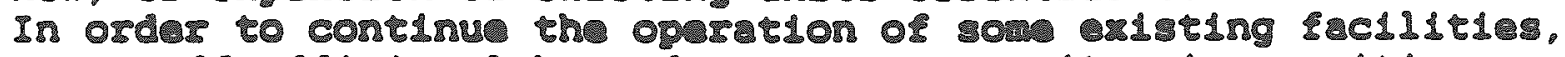

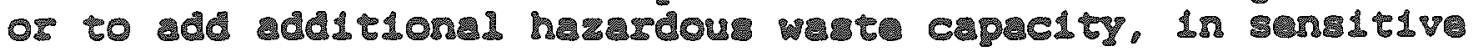
ares. Dor may have to provide Ignilicantly groater onvironmantal control and nondtoring reature in tho design of

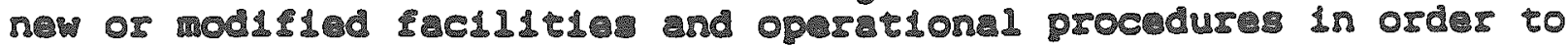
continue oporation in these areas. 
Because of the potential for severe discuptions in DOE operations, we are alerting you of these forthcoming drat regudations. In order to properly raspond to and comment on the regulations when they are published, wi: need to have g good understanding of whet the impacts on the various Dor raclidties and operetsons may be.

Therefore, we are requesting that you begin to asass, based on the 11mited 1nformetion glven above, the lmpacts these ragulatlons may have on your perticular feclditlos. When the proposed regulations are published in the Federal Reglster. we wli provide you with complete copy for surther analysis and submission of comments to Headqurters for preparation of a consolidated DOE response to EPA.

If you have any guestions pertaining to the above please contact Jerty Colgate of my stafs at FTS 896-6075 or (202) 586-6075.

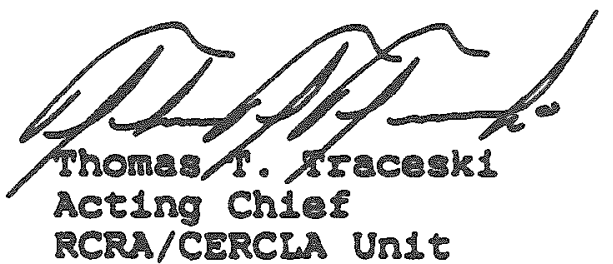

RCRA/CERCLA URLt

Rnironantel Guldance Division

Attachment 


\section{OUTLINE OF SUBTITLE C LOCATION STANDARDS}

\section{LOCATION CATEGOPUES AND CONDITUONS}

TO BE ADDRESSED

(1) ADVEVSE GEOLOGIC SETTUNGS -SEISMIC IMPACT ZONES

-FLOOOPLAINS

[NOLCANIC IMPACT ZONES]

[COASTAL APEAS']

(2) UNSTABLE AREAS

-POOA FOUNDATION CONDITIONS

- LANDSLIDE SUSCEPTIBLE AREAS

- KARST TERAAINS

(3) ECOLOGICAL AESOURCES

in -WETLANDS

(4) POPULATION PROXHIITY -BUFFER ZONES

- CATASTROPHC AIR RELEASES

(5) COMPLEX MYOPOGEOLOGY -GROUND-WATER CHAAACTERIZATION* -GROUND-WATER MONITORABILUTY

(6) PESOURCE PROTECTION GROUND WATER -SUAFACE WATER

\section{MKELY OPTIONS FOR PROPOSED STAMDAROS}

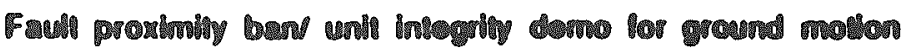

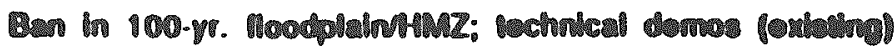

Solicil comments th Promber

sollch contrinents in Preanblo

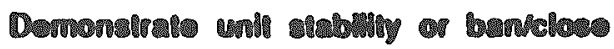

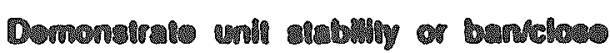

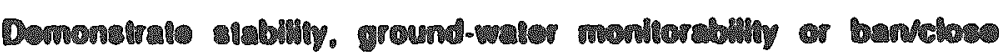

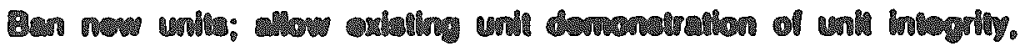

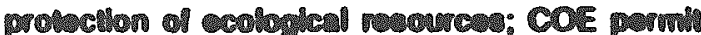

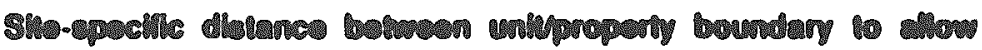
correcture aclon reapaneo

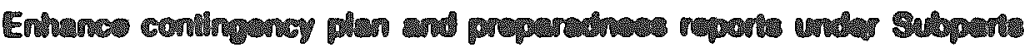
C and D

Rogutre ground

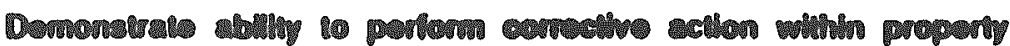

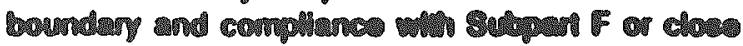

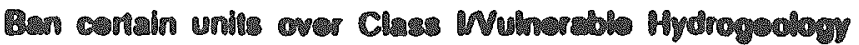

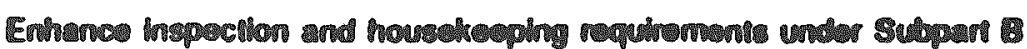

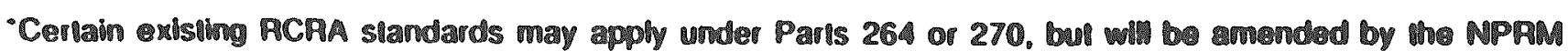




\section{APPENDIX G}

EPA Memorandum on Equivalency Demonstrations 


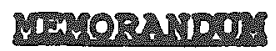

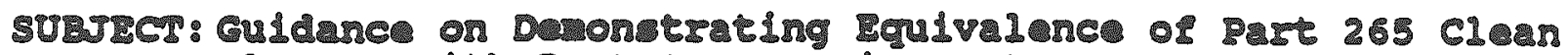

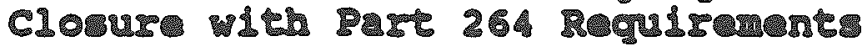

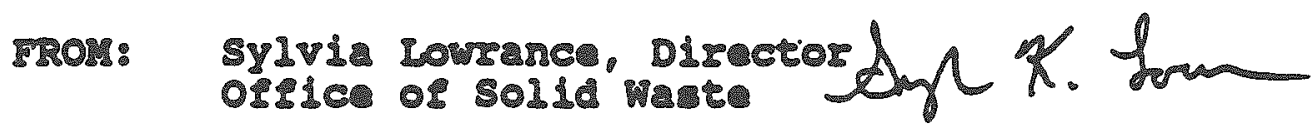

TO: $\quad$ Regione $I-X$

1. PURPOS笉

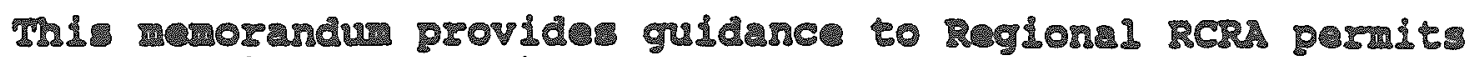

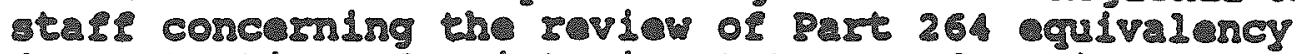

damontretone

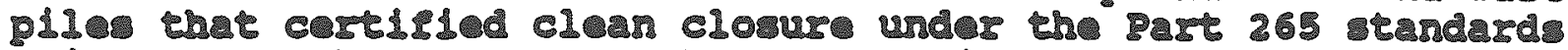

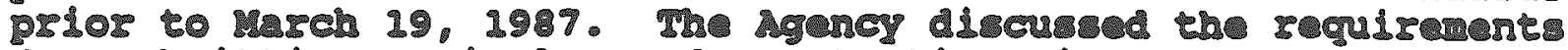

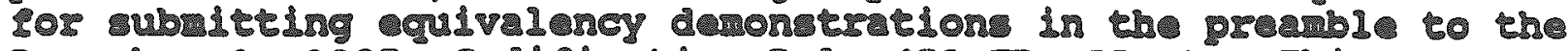

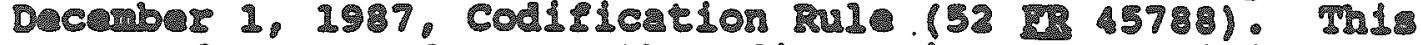
ranorandu aspands upon that discuston by provlding surther

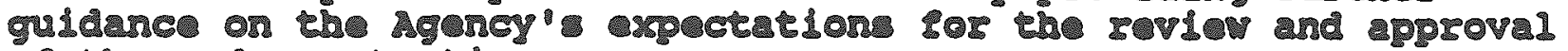
or chese darorestion.

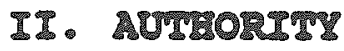

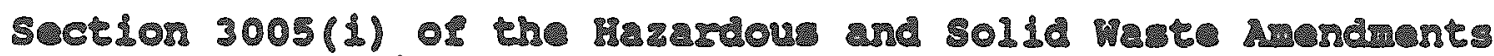

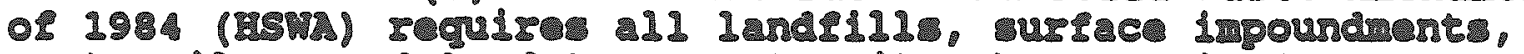

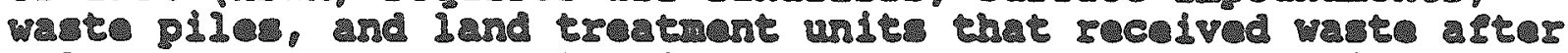

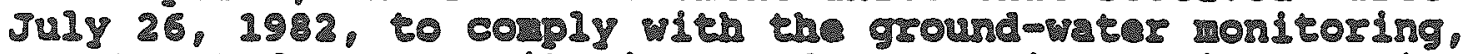

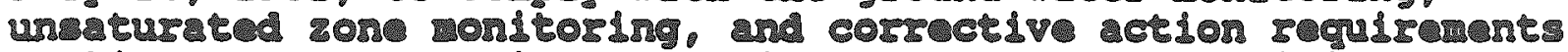

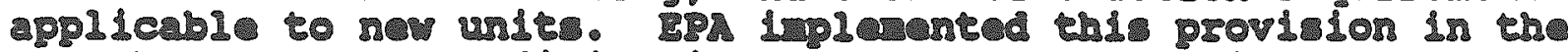

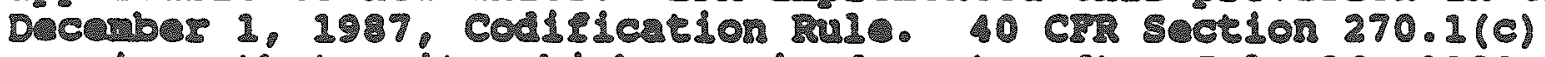

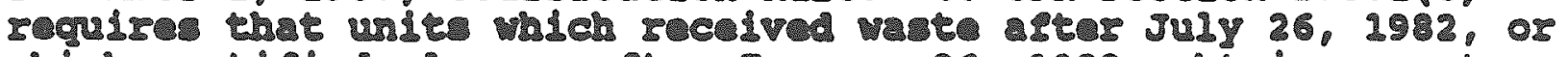

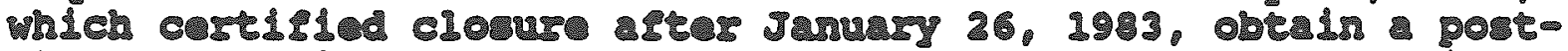

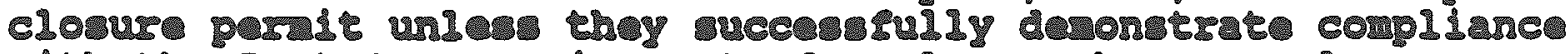

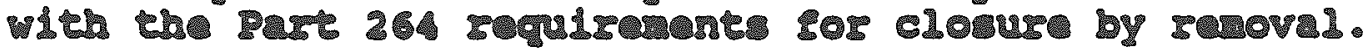

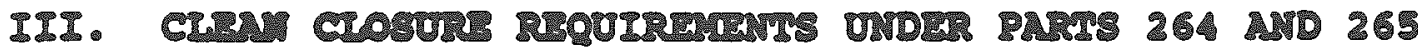

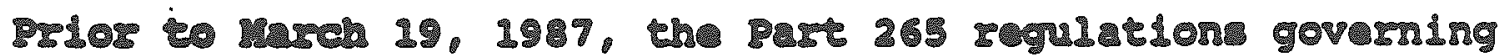

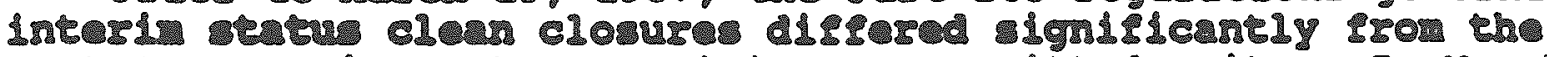

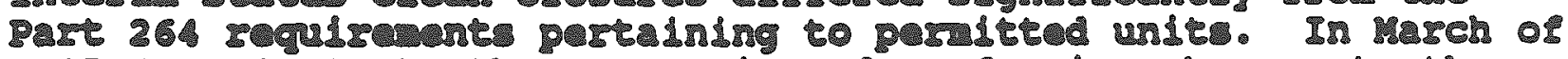

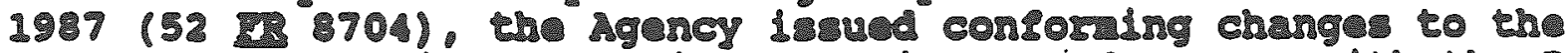
Part 265 regulation to bring tha dito consomanco vith the Part 26 regulsanter.

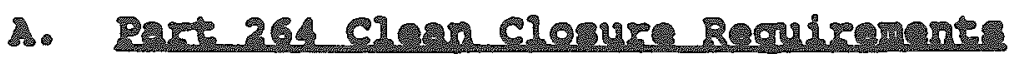

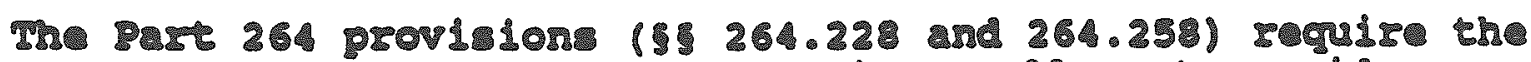

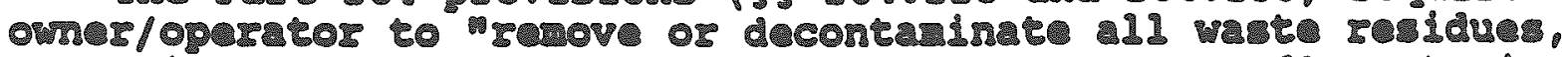

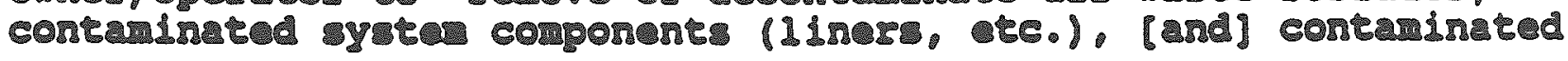




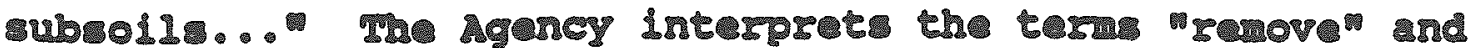

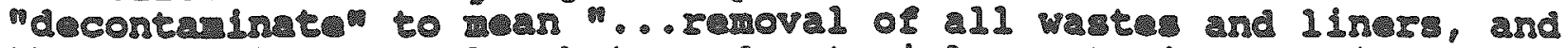
the removal of 11 leachate and materials contamisated with the wet or leachate (Including ground water) that pose a substantlal present or potontial threat to bunan health or the

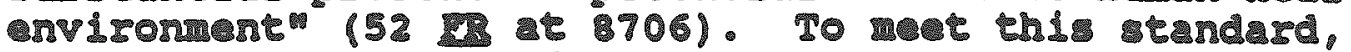
owner/operators must demonstrate that no Part 261 Appendir. VIII constitunte remin in the solis, vadose zone, or groundwater abve Agency-recomended limite botore certliying clean closure.

Trese Agency-aproved Iimits or sactor include water quality standard and criteria, health-based limit based on verifled reforence doses (RID) and Carcinogunic Potency Factors (CPF), or Ite-bpecilic Agency-approved belth advisories (52 IR at 8706$)$.

When asseseing potential exposures to conetruente released srom the unit, the owner/oparator mut ostablish the points of compliance directly at or within the unit boundary for all zoutes of exposure (surlace water contact, ground-weter ingestion, innalation, difret contact, and soli ingestion). In setting these point of compliance, consideration of contaninant

attenuation batwen the unit and potentlal exponure polnts is not allowed.

Further difcuesion of these zeguirenents is provided in the preamble to tho March 19, 1987, conforming change regulation (52 [R 8704), and in abseguent Notice or clarification lisued on March 28, 1988 (53 FR 9944). Pending the up-coming ismunce of the clean clomr gridance mentloned in the Marcb 19, 1987. preamil, these two ource provide the IuIlest interpretation of Afgoncy pollcy concening the zecuirements aplicable to units undergoing clean closure.

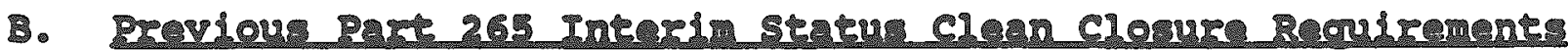

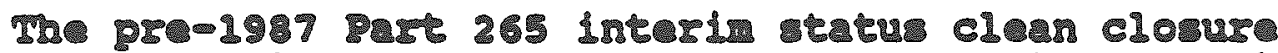
roguiromente discered fro the Bart 264 requirenonte in several signiflcant way. Firut. the standard allowed omer/operators to difcontine renovid actlvitie and cortily clomure if they war ablo to deronntrate that residual associated with the undt were no longer busmerous. This provision allowed owner/ jourators of surlace impoundmente containing solely characteristle wastes to met tho clean clowure standayd by dewonetrating that wastos no longer axhiblt the charactoristic that first brought the inpoundinent under regulatory control. In this stuation, owner/operatore could hav clean closed without evaluating the presence of addtiona Appendix VIII constituents that could pose - threat to bunan bealts or tho environnent.

SccondIy, the interin status ground-watar monitoring requiremente applicable to these unite only roquired 


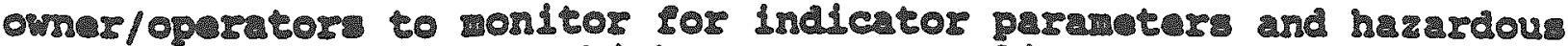

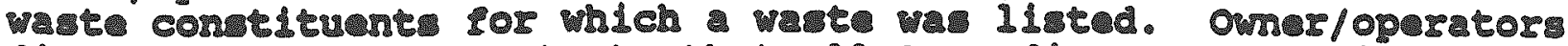
ald not bro to deonstre the 11 Appondix VIII constituents that could pos a thret to human bell or the onvisonnent had ban zonovad In ordar to cortify clan clomur.

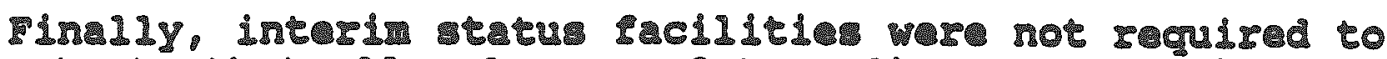

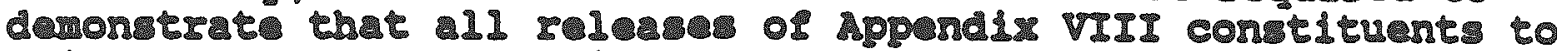

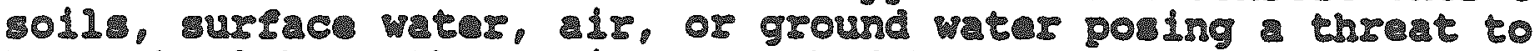
buman hedth or the onvironmant had boen removed at closure.

\section{EOUIVAIENCY DEMONSTRATON IMPORMATON REOUIREMNTS}

\section{A. Goner In ronation Requirements Ror Rouivalency Demonetration}

40 CR Scction 270.1 (c) not allord omer/operator ubo

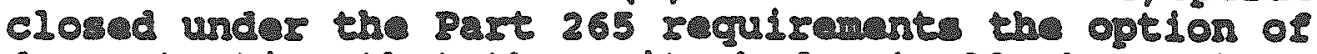
danonetring that the unIt had actualy ben closed in

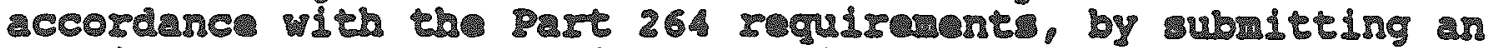

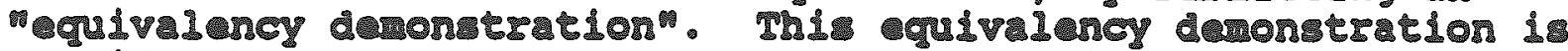

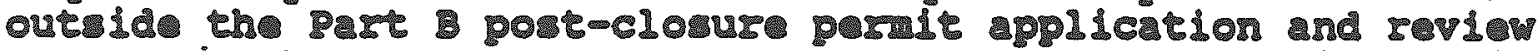

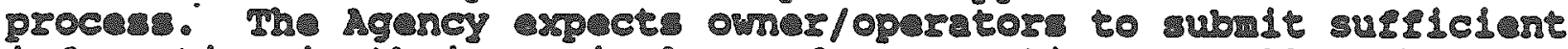

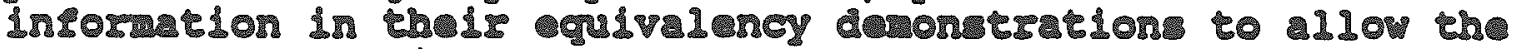
Agency to dotrine mathor tho clan clowre buly conoly wlth

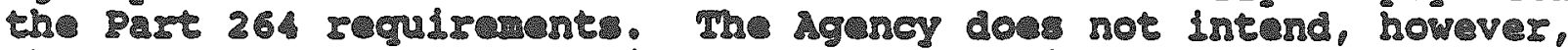

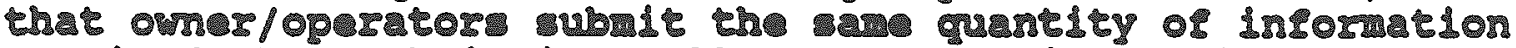
regulrea uhen :ubitting

The danonetretor subritted by the orner/opartor nust

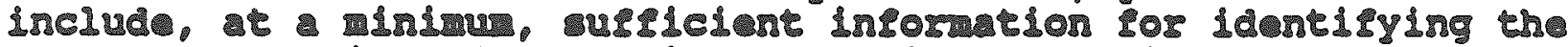

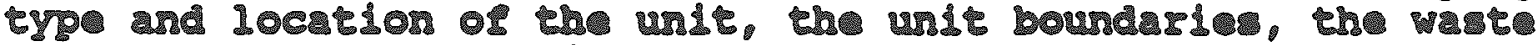
that bed boon anned in tho unit, and the oxtent ol wester and

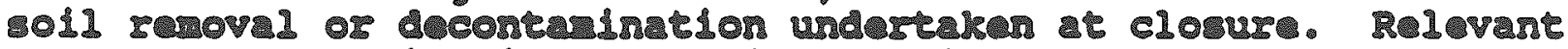

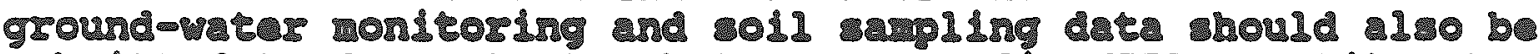

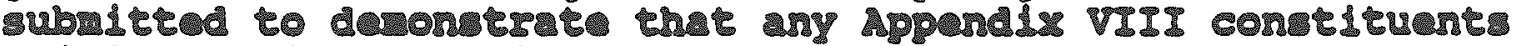

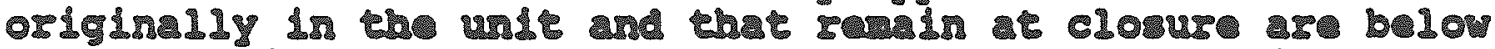

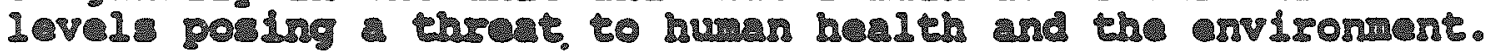

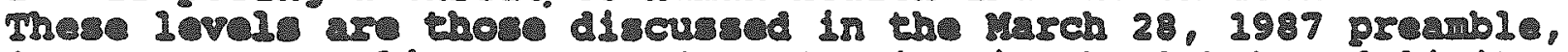

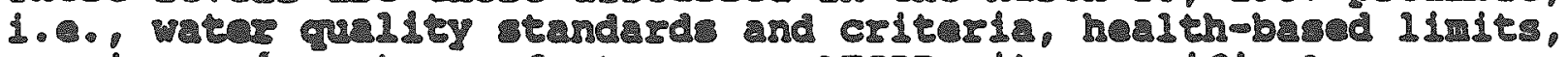

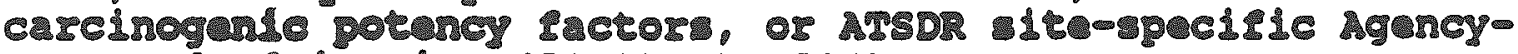

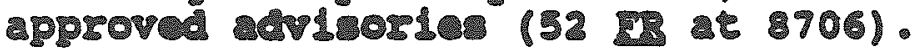

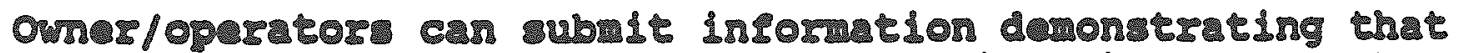

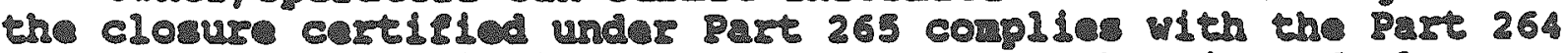

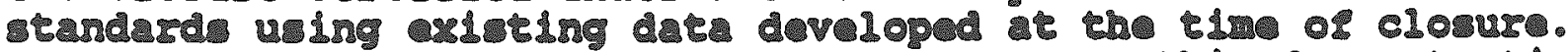

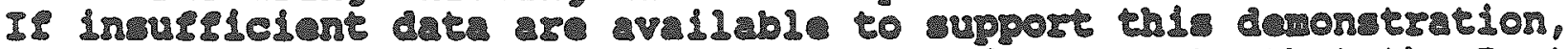

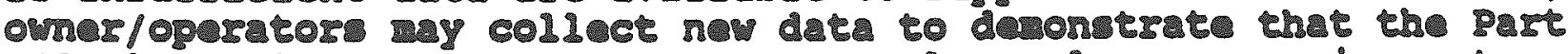

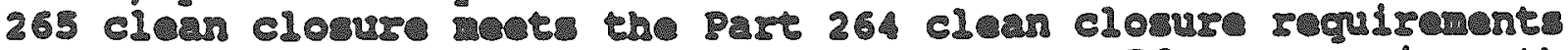

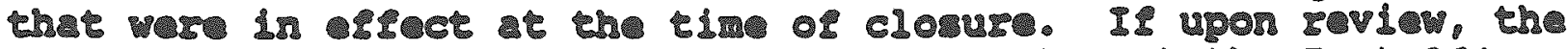

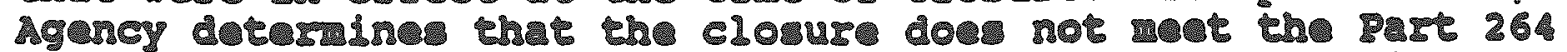

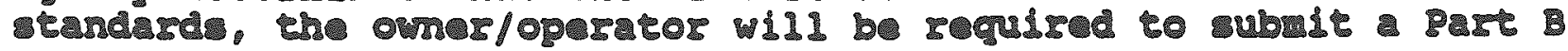


pernte application containing il the applicable information required in Pagt 270, ineluding ground-water monitoring incormatsos.

B. Acceptability of Speciple In Lormation Supporting Eoulvalency Demonstration

FIv potential iscues concerning the acceptablity of specifle kind of data used in an equivalency devonetzation have boen 1dentilled. Thes issues are discureed bolow.

\section{Accentability of Previously collected Data}

Many Iacility owner/operator will bave generated considerabl anount of data during tbeir original closur activitios. To the axtent that these data represent the conditions closure and provide unflelont inioration to

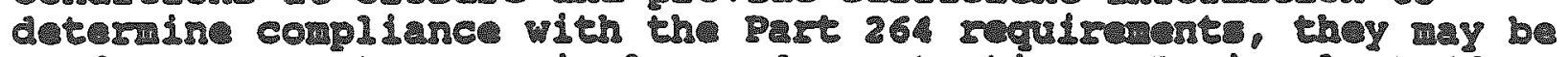
used to mpport an guivalency demontratlon. Roglonal mer should evaluate the insorwation 105 the artent to which it fulfild the reguiraments of Part 264, and Por Ite overall grulity, rellability, and accuracy.

mill previously collected data bay bed, in any cases omer/operator wil need to collect som additional information on hamardous constltuents that ray renaln in the molis, vadose zone, or ground water to demonstrate equivalency.

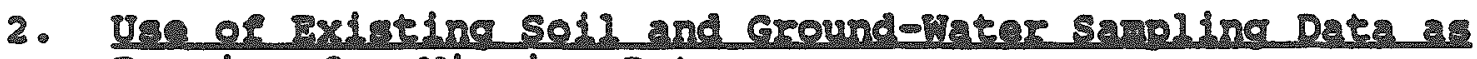 Proxia for uleing Date}

The Agency bolieve that in IImited case omer/opmators may us oxisting soll and ground-weter samping data as proxios

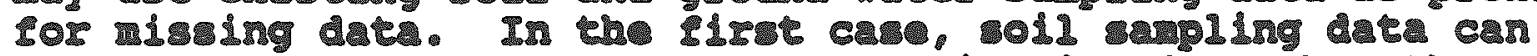
serve as a proxy cor ground-water monitoring dete when thece are not avilable. In the second care, ground-water monitoring data can be used to demonatrate the accoptabllity ol soll or vadose

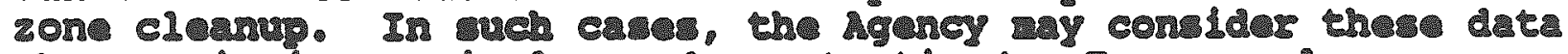
when revleulng egulvaleney denonatrationt. For exaple, som omner/opesetor ina will to ur previouly collected coil sampling det a a surrogate por actual ground-water sampling data in ortes to dononetrate complance with the part 264 ground-

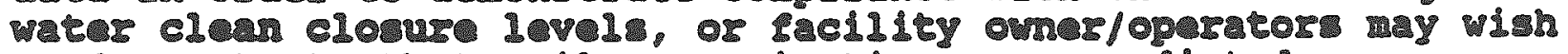
to demonetrate that soll contamination was remediated surelcienty by eubitting ground-water wonitoring data demonetreting no ilgration of contaninante jron the soll. It is

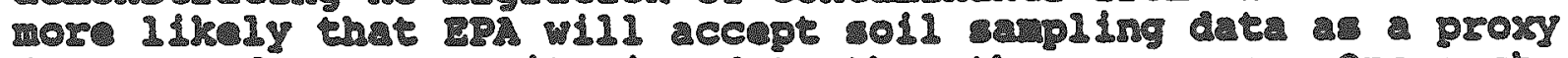
tor ground-water monitoring data than the converse. One such example of wher soll saping and vadose $20 n$ date night bo used as surrogate for ground-water samplng data is in hydrogeologic steing where the water thic is located at 


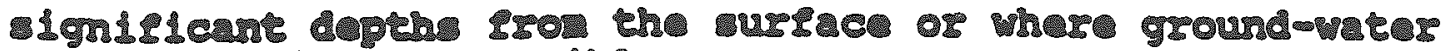

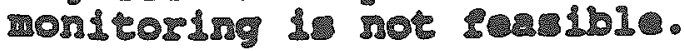

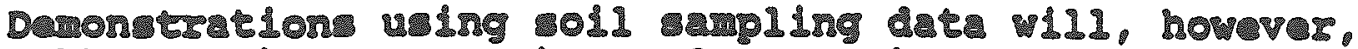

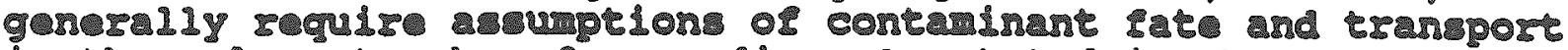

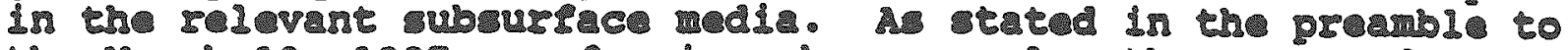

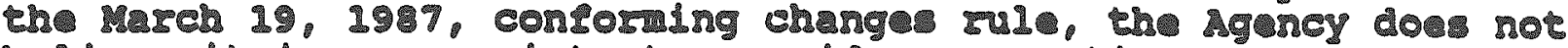

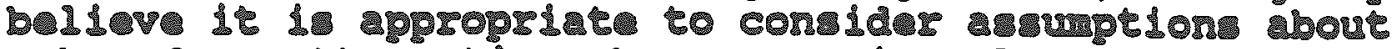

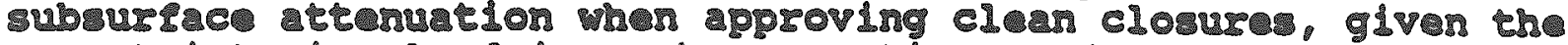
uncetrinty Involved In such asumptons and the pact that all 1urther regulatory control ends upon cortiplcation of the closuse.

\section{Rouirement for Full Aopendix VII samoling}

The Part 264 clan clovure standarde regulro domontration thet 11 IPFandx VII constituent originaly in tho unit bav

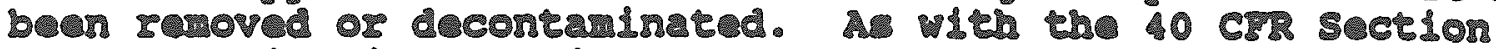

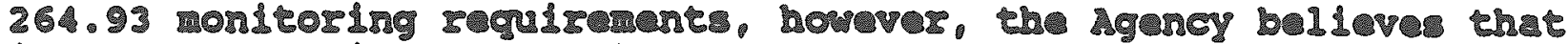

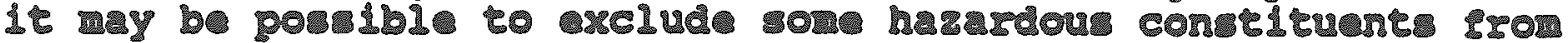

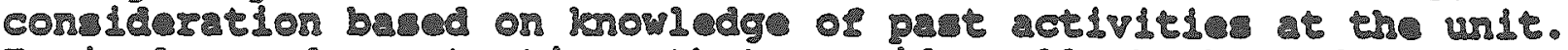

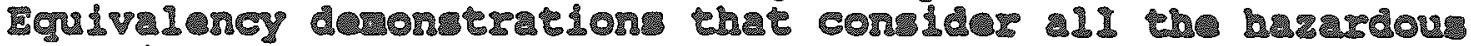

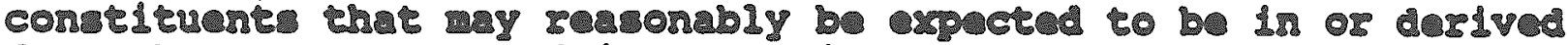

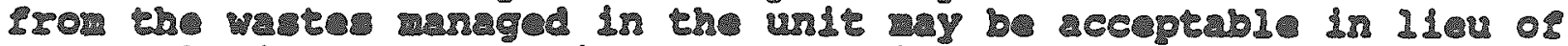

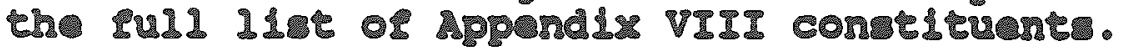

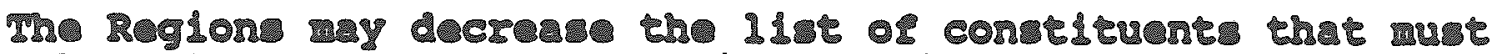
bo ovalueted to the artent the Inforraton subritced by the

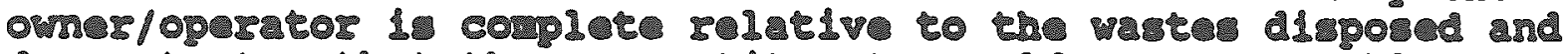

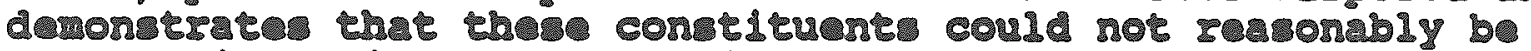

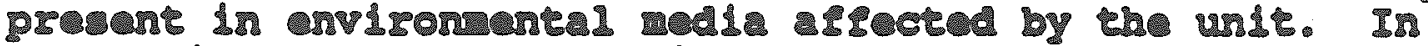

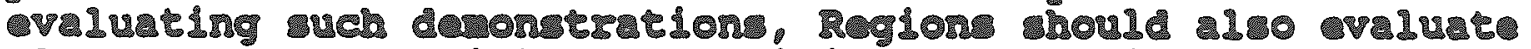

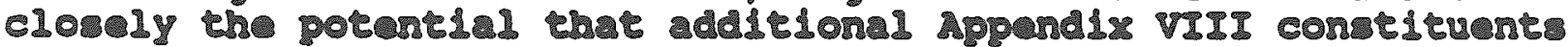
nay bo provant is the olla or ground wator baneth the unit.

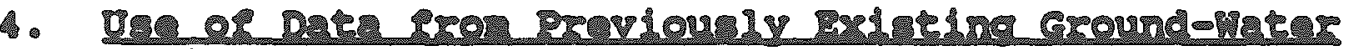 Monitoring Burten}

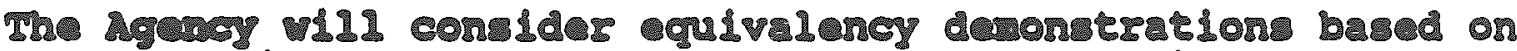

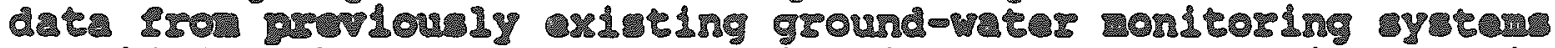

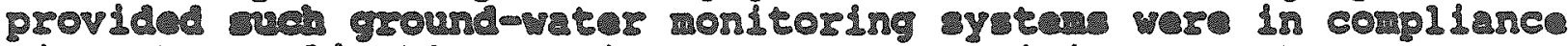

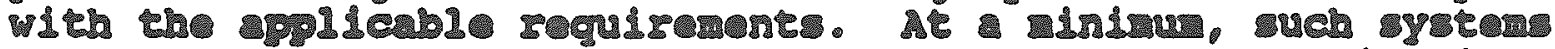

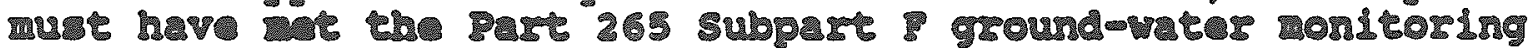

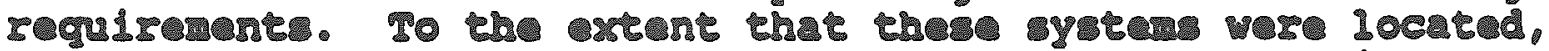

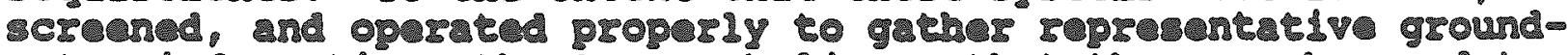

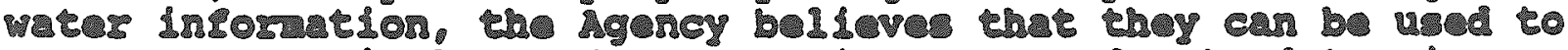

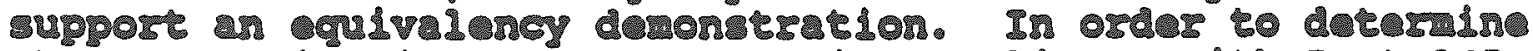
whethar nonltoring y

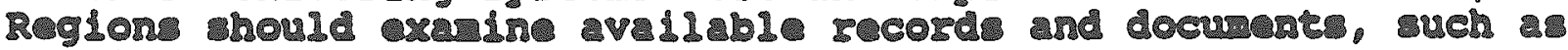

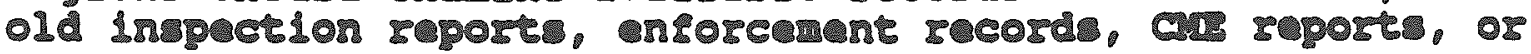
Ground-Pleter Takk Forco reports. 


\section{Practerbility of Obtalning Nar Date}

Sor facliftie will bave certilled clean closure several year ago, and mbecusuty ma heve constructed atructures on top of clean closed undte, raking it dillicult to obtain nov data For the grivalency denontration. For axample bullding with a concret bloor or matowter treatent unit contructed on top of cleas closed hazardous vaste management undt could obstruct the collectios of now maling data. Collecting new soll or ground-Wret date st such site night reguire ithar drilling through the concrete floor of the building or using angled dr111ing techndgues.

The Agency recognimes the dilifulties aneociated with data collection in the cases. In reviowing the guantlty of such date submitted, the Rogions may consider the technical diflicultie involved in collecting such data. The standard of protection aginst which eguivalency demonttation will bo -valuated wil not, bowever, be dilferent depending on the technical difficulties of date collection. Mccordingly, the Agency will reguire ouner/operators to subnit representeatve existing.data and/or to collect thos data necessary to demonetrate compliance wib the Part 264 reguirenente.

\section{APPLICABIITY TO LAMDILIS}

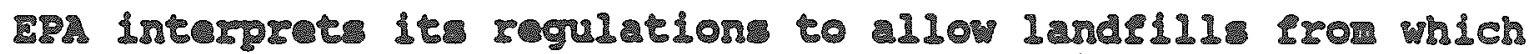
water have beon renoved at closur to cecomplish "clean closur" and, 11 closed under $40 \mathrm{CFR}$ Part 265 tandards, to dLow -grivalmey denonetration to be nade under 40 cFr section $270.1(c)(5)$ and $(6)$. through raderinition of the landilil as as waste pile, suriace igoound ent, or land trestment unit. It is most likely that the redecinition, or change in procese. wild be to wate pile, pureuant to $40 \mathrm{Cr}$ section $270.72(\mathrm{c})$. Clean cloure or demontreten of chiviency with clean closure. are governed by the applicable part 254 clowure raguiranents (1.9.. $40 \mathrm{CR}$ Section 264.25 cor waste piles).

Is an ltesultre to making an equiviency demonetration pursuant to 10 Cre section 270.1(c)(5). the owner/operator of a

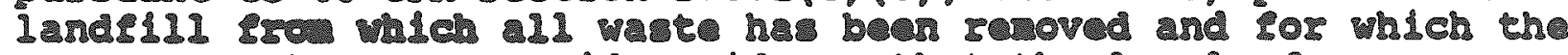
owrser/operator ea provide ovidence that the level or containation is web that it no longer poses a throat to human health and the cnvironent, way request that the Reglonal Adninietrator chorten the poet-clowure care porlod iso CrR Section 264.117(1)(2)(1) ). The ter of the post-closure perait should then be wodifled to minimal pariod in accordance with 40 CrR sect Ior 270.42 . 


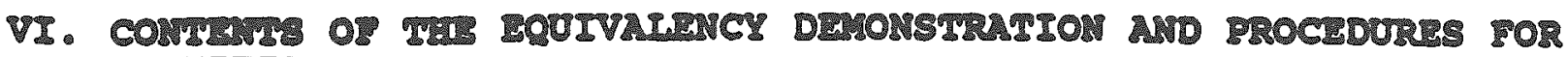
SUERT 2I:

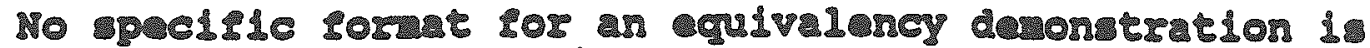

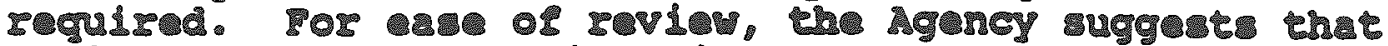

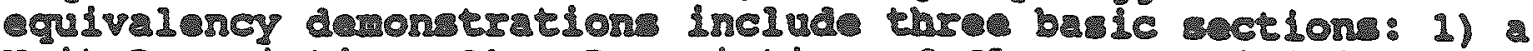

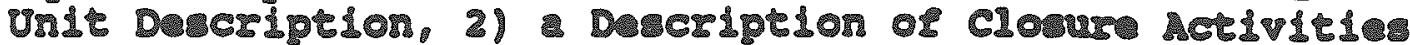
conducted and 3) Danontration of Complance Closure Lavele.

The Iret action, Unit Description, should provide

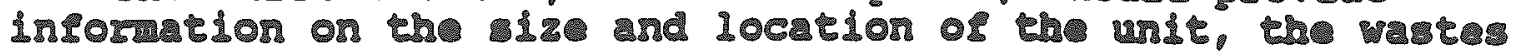

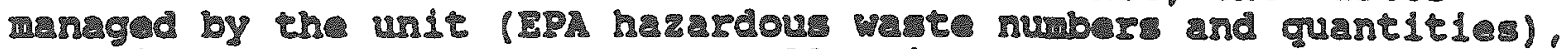

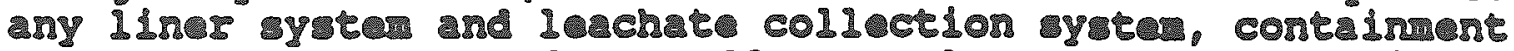

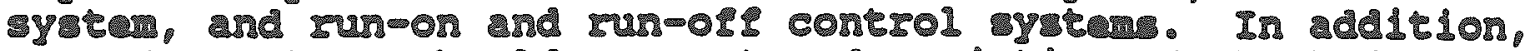
owner/operetore bould present doscripton of the hydrogeology of tho inmedite ares. Including descripton or ground-ber and

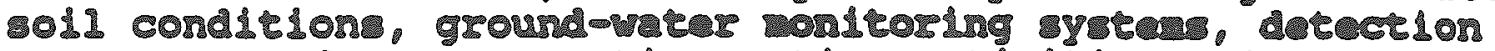
progran, and any corrective acton activitio undertakn.

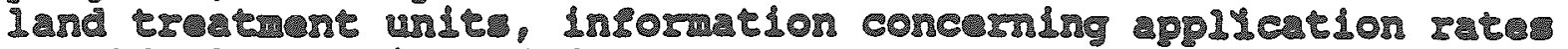
Should 1 bo be included.

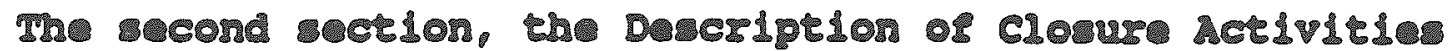

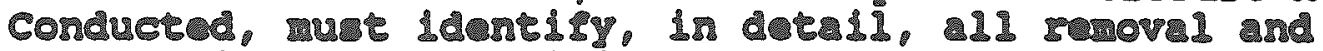

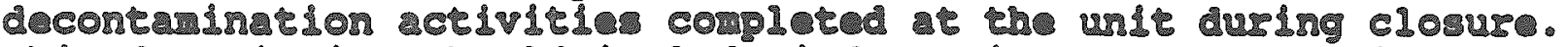

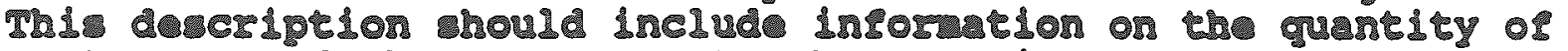

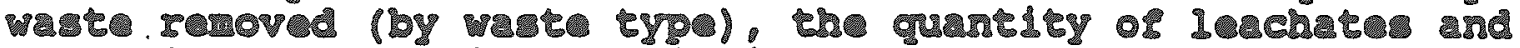

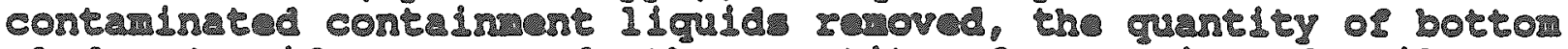

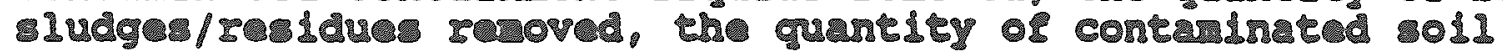

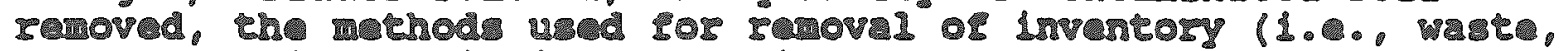

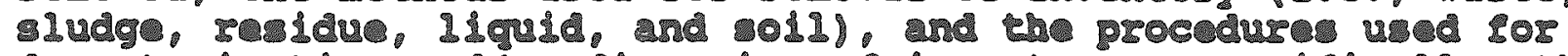

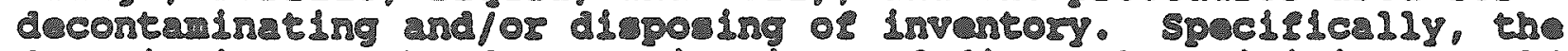

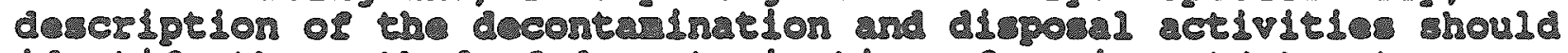

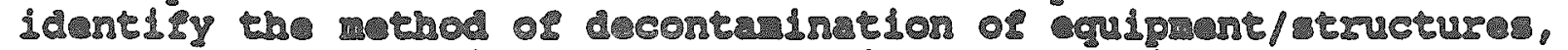

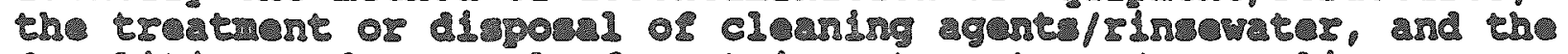

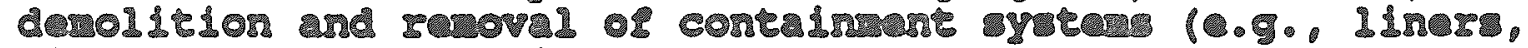

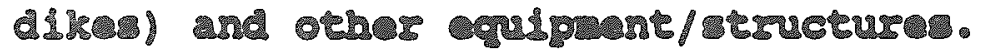

ma provlounly poroved clovura plan bould provide the

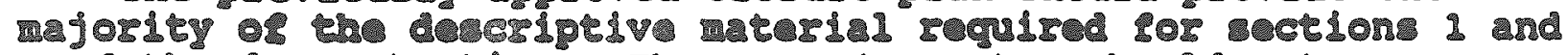

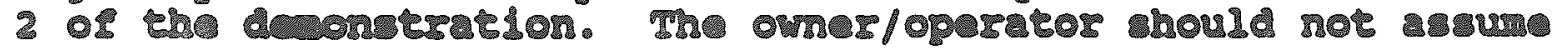

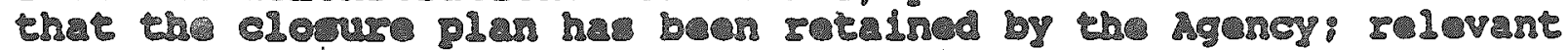
portlons os be plan hould be zerublted. 2 cory os the

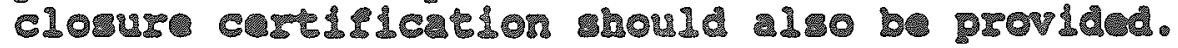

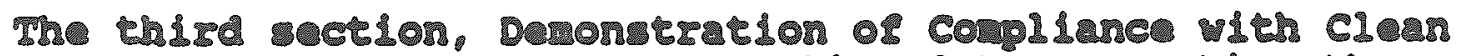

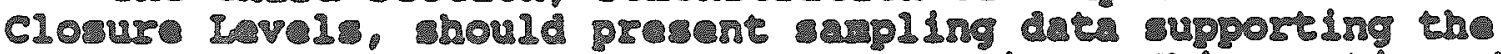

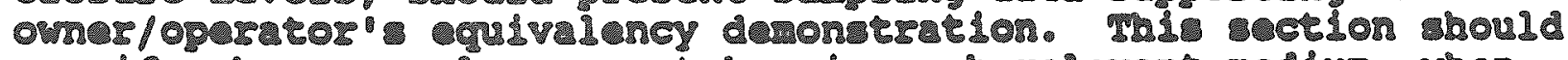

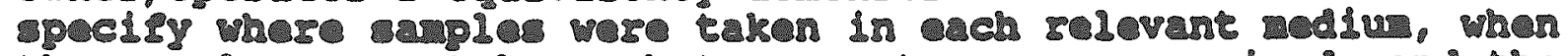

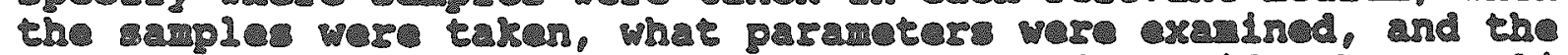

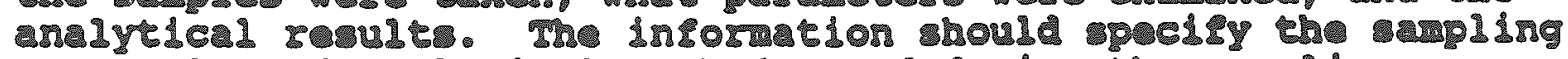
protocols and andyrical athods used during the ranglng 


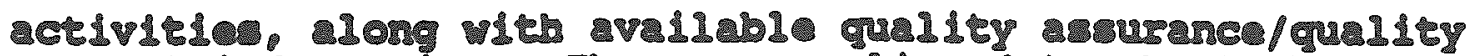

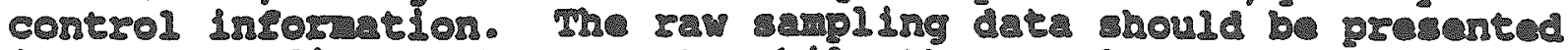
Is an appands to the roport, whi the results ubould bo

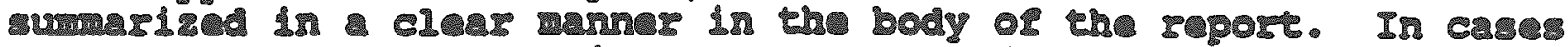

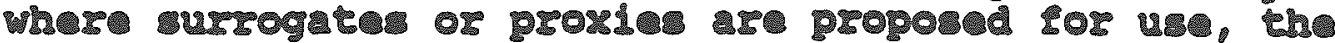

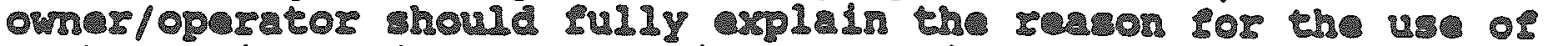

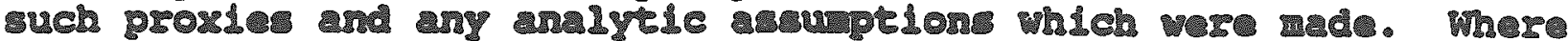

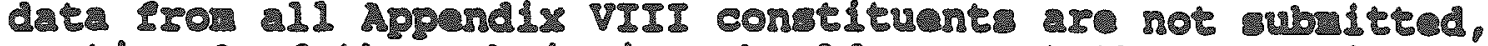

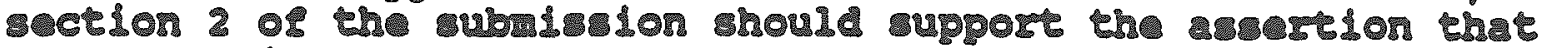

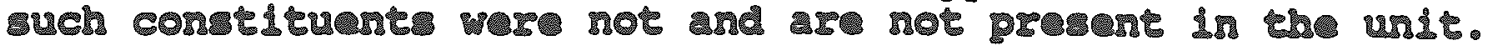

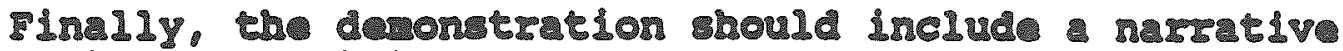

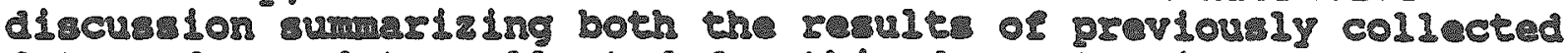

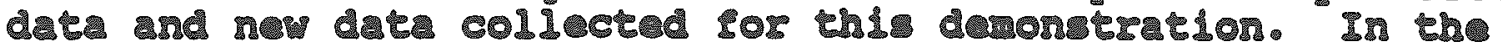

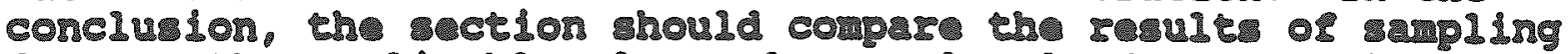

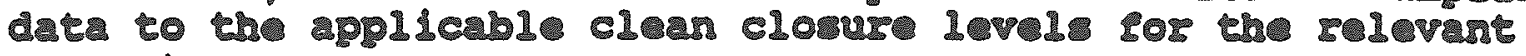
paranotere.

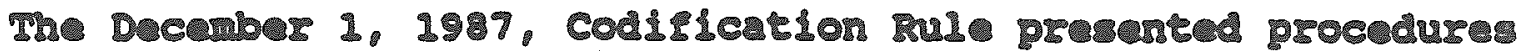

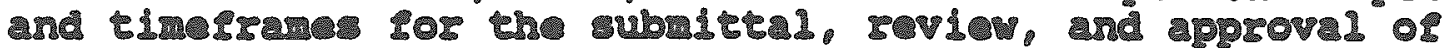

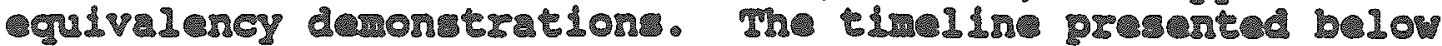

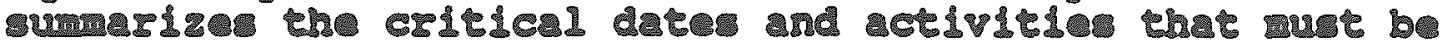

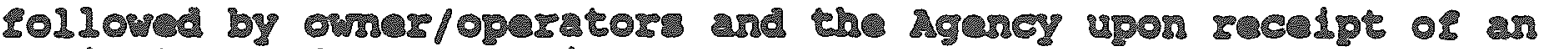
cgulvalescy denonstrater.

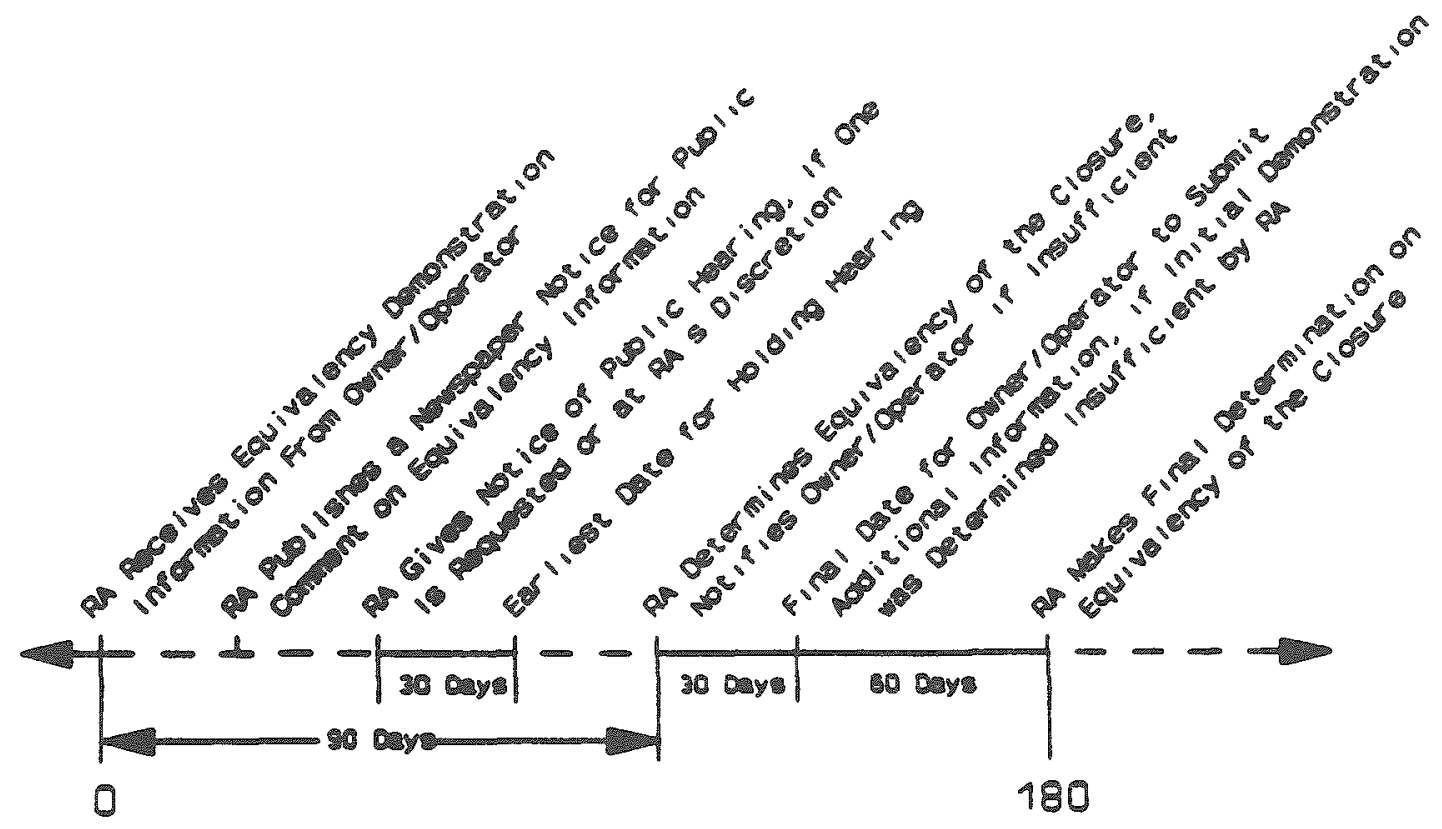




\section{APPENDIX H}

Joint NRC-EPA Guidance on Siting of Mixed Low-Level Radioactive and Hazardous Waste Units

(Source: EPA Mixed Waste Traiming Course) 


\section{MaP 13169}

TO THE STATES AND COMPACT REGIONS:

SUBJECT: COMBIMED RRC-EPA SITING GUIDELINES FOR OISPOSAL OF RIXED LOH-LEVEL RADIOACTIVE AMO HAZARDOUS WASTE

As you are wre the Low-level Radioactive waste Polley Amenduents Act of 1985 (LLRUPA) established milestones (and pendieles for not neting these mllestones) to ensure adenuat development of puture disposel capactey for

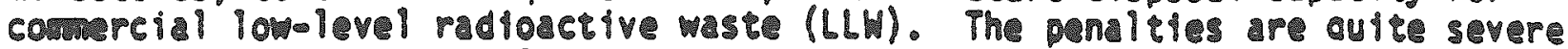
and the deadines not leave mech room for slippage.

We would itke to cell to your attention the january 1. 1988 milestone (Section

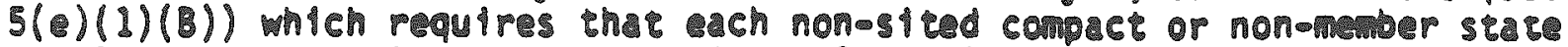
develop siting plan for LLW disposel peflity. These siting pins mist inciude decelled procedures and schedule for establishing disposal factllty location and preparing license applickion. Among other things. Section $5(\mathrm{e})(1)(\mathrm{B})(\mathrm{ifl})$ provides the the sleing plan shall:

m... idently. to the exten practledble the process for (I) sereening fop broad sting res: (2) identifying and viluating spectitic candidate sites: and (3) charactertzing the preferred stee(s)...."

This letter serves poup purposes:

(1) to Inform states and compacts that, under current Federal Iam, the U.S. Muclear Reguiatory Comission (IRC) and the U.S. Environgental Protection Agency (EPA) have dual jurtsdlebton over mined low-level radiocetive and hazardous waste (Mined LLW): (2) to state tha both NRC and PPM do not consider the absence of EPA's flmell comprehensive location standards to b justification for states and compacts to not mere their obligetions under the LLRWMA: (3) to convey thet both NRC and EPA are comithed to providing guidance to states and compacts tho request help in cheir epforts to meet the january 1988 LLRWPA milestone Pop sising lans: and (4) to jolntly transmls the NRC-EPA conbined siting guldelfines Por Mined LLW (enclosed).

Dual statucory authority extsts for Mixed HWH. Which is regulated by the NRC under the Accic Energy Acs (AEA). as amsnded, and by PPA under the Resource Conservetion and Recovery Act (RCRA). as mended. Mixed bbl is defined as waste that satisfies the definttion of LLW in the LLRWPA and contains hazardous wete that either is iIsted in 40 CFR Part 261 Subpart D op causes the blt to exhlbit any of the hasardous waste characteristics ldentified in 40 CFR Part 261 SUbpart C. Both the MhC and EPA stapts consider chat MIned LLH 
can be dispesed of in accordance with the bove statutes and NRC and EPA regulations.

in 1982. the NRC promulgated regulathons containing winlmum slte suitability requiramencs for LLW land disposal facllieles under 10 CFR Part 6l. In 1981. EPA promuigated minimun location standards for hazardous waste treatment. storgye. and disposal Pacilities in 40 CFR Part 264 . Secton 3004(0)(7) of RCRA. which ws added by the Hazardous and Solid Waste Amendments of 1984 (HSWA). Pequires EPA to publish guidance fdentriying areas of vulnereble hydrogeology: this guidance was completed and issued in July 1986. Section 3004(0)(7) of RCRA I Iso requires EPA ro specify criterie for the accepable locetion of new and existing hazardous waste treatuent. storage, and disposal pacilities as necessary to protect human health and the environment. PBA anticipates proposing these location standards in Septenber 1987 and promylgating then by september 1888. This schedule provides aprected scates and compacts with preview of the final standards and an opportunt ty coment on the standards before promigrtion.

Because of uncerteinty about the precise consent of PPA's future location standards. states and compacts may have questons regarding the slte selection process. Both NRC and EPA are comintect to providing guidance to states and compaces who request help in developing their siting plans by the January b. 1988 deadline. Technical questions pertaining to siting disposal faciliby for MIxed LLW should be submitced in witing to elther the MRG or EA contacts listed below. as approprite.

For questions about the LLRUPAA siting deadine or MRC's sile suitability requirements, contact:

Dr. Sher Bahadur

Division of Waste Minagenent

Mail Stop 623-5s

U.S. Nuclear Regulatory Commission Washington. D.C. 20555
For questions relating to

EPA's location standards contact:

Mr. Eurnell Vincent

Wast Mangement Oivision

Mail Code WH-565

U.S. Environmental Protection Agency

Washington, D.C. 20460 
In sumery. if states and compacts observe the enclosed NRC-RPA combined siting guidelines and keep abreas of the developing PPA location standards. the absence of PInal RCRA locarion standards snould not prevent steres ane compacts from meeting their obligations under the LLRWPAA.

Sincerely.

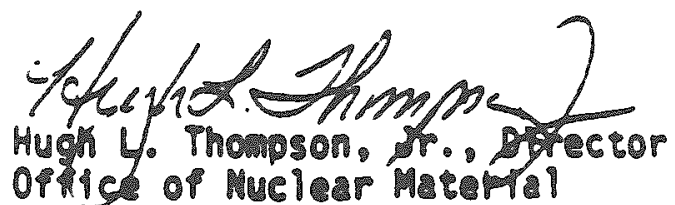

Sâtery anc satreguards

U.S. Nuclear Regulacory Comission

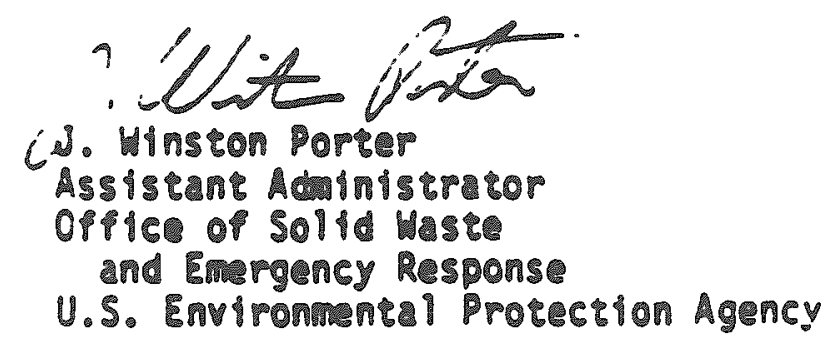

Enclosure:

As stated 


\section{COMEINED NRC-EPA SITING GUIDELINES FOR DISPOSAL OF COMIERCIAL} MIXEO LOW-LEVEL RADIOACTIVE AMO HAZARDOUS WASTES

\section{introduction}

The Low-Level Radtoactive Haste Policy Amendinents Act of 1985 (LLRMPMA) requires states and compacts to develop siting plans for lowelevel radiactive waste (LLW) disposal factlittes by January 1. 1983. These dIsposal pacilities may receive comarcial mixed low-ievel radioactive and hazardous waste (Mixed UWW. Which is regulated by the U.S. Nuelear Regulatory Connission (MRC) under the ÁcontC Energy Act (AEA), as amended, and by the U.S. Envi ronmental Protection Agency (EPA) under the Resource Conservation and Recovery Act (RCRA). as amended. Mixed LLW is defined as waste that satisfles the definition of LLW in the LLRWPAA and containg hazardous waste that either is listed in Subpart $D$ of 40 CFR Part 261 or causes the LLW to exhibit any of the hazardous waste characterlstics identfied in Subpapt $C$ of 40 CPR Part 261. To assist in applying that derinition. HRC and EPA recenty developed joint guidance entitled "Guidance on the Definttion and Identification of Comerefal MIxed Low-bevel Radioactive and Hazardous Maste and Answers to Anticlpeted Questions" (Jan. 8, 1987). ARC has promilgated LLU regulations and EPA has promulgated hazardous waste regulatons that partain to the siting requirenents for disposal Pacilities fur Mixed LLH. Because of uncertainty bout the precise content of EPA's future location standards, states and compacts may have questions regarding the site selection process. This document provides combined MRC-EPA siting guidelines, to be used before EPA's new locarien seandards are promulgated. to facfiltate development of siting pians for disposa? facilities that may recelve Hixed LL.

Section $5(C)(1)(8)$ of the LLRMPAA requires staces and compacts to develop sting plans for LLW disposal facilities by January d. 1988. In addition to other information. these slting plans must identfy, to the extent practcable. the process for (1) screening for brod siting areas. (2) identifying and eviluating specific candidate sites. and (3) characterizing the preferped site(s). It is anticlpated that this process will be based primarly on the site sutrabllity requirenents that apply to blW disposel. If factlities also receive MIxed LLH. their slting requirements will Peflect aditional requireants that apply to disposal of hazardous waste as defined by RCRA.

In 1982. MRC promigated regulations which contaln minimum ste suitebility requirements for LLH land disposal pacilities in 10 CFR 61.50. EPA has also promigated minfmu location standards for hazardous maste treatment. storage. and disposal factlittes in 40 CFR 264.18. Conslderations affecting siting are a iso found in 40 CFR 270.3. 270.14(b) and (c). Although both MRC and EPA have incorporaced siting requirements in existing regulations for LLt and hazardous weste disposal. respoctively, the 1984 Hazardous and Solld Waste Amenements (HSUA) TO RCRA require EPA to pubiish guidance identifying areas of vulnerabie 
hydrogeology.- in July 1986. EPA published this oufdance in "Criteria for Identifying Areas of Vuinerabie Hydrogeology under the Resource Conservation and Recovery Act-oStatutory Interpretative Guidance, july 1986, Interim Find (PB-86-224953)." The 1984 HSHA iso requires (in Section 3004(0)(7)) that EPA spectify eriteria for the acceptable location of new and existing hazarcous waste treatment. Storage, and disposal Pactilities. BPA anticlpates proposing these location standards in September 1987 and promigating them in pinal porm by Seprember 1988.

EPA's scheduled date for promulgating its final location standards is nine months apter the LLRMPM January 1. 1988, milestone for non-sited states and compacts to develop string plans. Therefore, states and compacts may require some assistance in their efforts to develop stting plans for LLW dIsposal facilities that my receive Mixed LbW. The two agenctes ape issuing these combined guidelines to promote the development of siting plans by states and compacts. Both NRC and EPA consIder that the absence of EPA's Pinal comprehensive location standards for hazapdous waste disposal pacilities is not an adequate basts for states and compacts to diby development of siting plans for LLW dISposal.

States and compacts should proceed at this time co develop siting plans in accopdence with the existing MRC and EPA requirements. The following combined NRC-EPA guidelines are provided for use by the states and compacts. and are based on existing NRC regulations in $10 \mathrm{CF}$ Part 61 and EPA regulations in 40 CFR Parts 264 and 270. As EPA continues 1ts development of location standards. both agencles will strive to kep states and compacts infomed about the status of the developing siting requirenents.

Conbined MRC-EPA Sith Guidelines

Site sultability requirements for land disposal of $\mathrm{LLW}$ are provided in 10 CFR Section 61.50. These requirements constitute ninimu techntcal requt renents for geologic. hydrologic, and demographic characteristics of LLW disposal sites. Severs l of these requirenents identify favorable site characteristics for near-surface disposal facillities for LLU. The majority of the slte suitablity roguirements. homever. Identify potentialiy adverse slte characteriseles thet must not be present at LLW disposal sites. The site suitabilicy requirements in $10 \mathrm{GF}$ PaPt 61 are intended to function collectively wh the pequirewants for factlity design and operation. site closure, waste classification and segregation, waste fom and packaging. and inetrutional controls to assure isolation of LLW for the dupetion of the radfological hazard. Phe NaC Technical Position entitled "Site Suitabllity. Selection, and Characterization" (NuREG-0902) provides detalled guidance on implementing the site suitablitty requirements in 10 CPR Part 62.

EHA has disa fromulgated ceptain minimum location standards for hazardous waste treatment, storage, and disposal factivties. These standards are provided in H. 5 
40 GRR Section 264.12. As prevlously roted, the hazerdous waste regulations lso include other locetion consfderetions es wll as afplicable provisions of other Federel statuces. For example. Subpare P of 40 CFR Papt 264 requires establisment of ground-mater monthoring prograns capale or detecting contarinetion prow land disposal units. Whil not siting crlterton per se. this requircment can preciude sleing in locations the cannot be acquately monitored or characterlace. A fupther deserlption of location-related standards and applicale provisions of other Federal statutes can be found in the "Permit Hriters" Guidance Manul for Hazardous Waste band Storage and Disposal Pactlities: Phase I Critert Por Locaton Acceptablity and Existing Appilcable Regulations (FInal Drafe Feruary 1985). This guidance manul

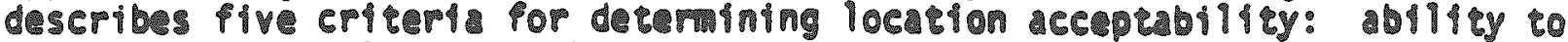
characterlze, excluston of high hazard and unstable terrain. ability co montior. exciuston of protected lands. and trentification op ares of vuinerable hydrogeolog. The first pous of these criteria have bus in the regulations and re rully deseribed in the manul. The pifth critsion. vuinerable hydrogeology, Is defined in bhe RCW Ineerprebive guidance manul mentioned above (Criteria for Identifying Areses of Vulnerable Hydrogeology under the Resource Conservation and Recovery Actosstertory interpretive Guldance. July 1966, Interim PInal (P6-86-229953)).

Howner, since WSWA 150 added other requirements in adtition co location

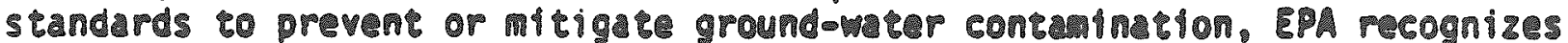
that vulnerable hydrogeology must be considered in conjunction with deslgn and operating practices. Vuinerablitisy should not be the sole deterwining pactor in RCRA siting decisions. Rather. this criterion provides trigger for more detailed viluation of sites that are identified as having potentially vulnerable hydrogeology. The extent of necessary site revien and cvaluation is related directly to the extent to which a location "istis" or "Desses" the vuinerability criterion. Sites that are detcrinined to be extrenty vulnerable will require much closer examination than sites that are dected nonmulnerable. The results of this nore detalled revich ray then provide a basis for eventual pemit conditions or modifictions In deslgn or operebing practices.

By conthing the bove technical requirentents. standards. and guidence of both agencles. WC and EPA have formulaced the liven guidelines IIsta below. The

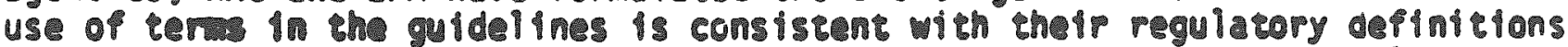
in 10 CFP Pare 11 and 40 CFR Parts 260 and 264. The combined set of location gutdelines is intended by the ageneles to apply only as gutdence to states and compacts developing siting plans for bLU disposal pacilities thet my receive Mixed LLW. These combined guldelines re not intented to displace existing standards and guidance. In addliton. the independant guidance of both agencies should be consldered in any applicaston of the combned sletng duldellnes.

The comblned steing guidelines for comercial Mixed LLU diposal facility are as follows: 
i. Primary emphasis in disposal stee suitability should be given to isolation of wastes and to disposal site peatures thet ensure that the iong-term performance objectves of 10 CFR Part 61 , Subpapt $C$ are met.

2. The disposal site shall be capable of being characterized, modeled, analyzed, and monitored. At a minimum, site characterlzation must be bible to (a) delineate ground-water flow paths, (b) estimate groundowater fiow velocities, and (c) deterwine geotechnical properties suppleienty to support factitidy design. At a minimu for site groundowater monitoring, disposal site operators must be bie to (ㄱ) sssess the rate and direction of groundawater flow in the uppernost aquifer, (b) determine background ground-water quality, and (c) prompty detect ground-water contamination.

3. The disposal site must be generally well-drained (with respect to surface water) and free of areas of flooding or prequent ponding.

4. The disposal site shall not be in the 100-year ploodplain.

5. The site must be located so that upstream dpainage areas ape mininized to decrease the amount of runoff that could erode or inundate waste disposal units.

6. Disposal sites may not be located on lands spectified in 10 CFR Section 61.50(a)(5). including wetlands (Clean water Act) and coastal high hazard areas (Coesta) Zone Managenent Act). Location of pacilities on the following lands must be consistene with requirements of applicable Federal stacutes: archeological and historic places (National Histoptc Places Act): endangered or threatened habitats (Endangered Species ACt): national parks, monuments, and scente pivers (Wild and Scente Rivers Act): wilderness areas (UIIderness Protection Act): and wildi ife Pefuges (Mational Wildife Refuge Systen Adninistration Act).

7. The disposal site should provide a stable foundation for engineered containmene structures.

8. Disposal stes must not be located in areas where:

(a) tectonic processes such as fauting, folding, seismic activity, or vulcanis my occup with such frequency and extene to affect significantiy the ablitity of the disposal facillty to satisfy the performance cojectives specified in Subpare $C$ of 10 CFR Part 61 , or may preclude defensible modeling and prediction of long-term impacts: in particular, sites must be located more than 200 fetet from fault that has been active during the Holocene Epocti:

(b) surface geologic processes such as mass wasting, erosion, slumping, larissliding, or weathering occur with such frequency and extent to affec: 
significanty the ablitey of the disposel fachlity to meet the perfomance objectives in subpare $C$ of 10 CFR Pare 6 b. or may preclude defensible modeling and prediction of long-rem impacts:

(c) natural resources aist shat, if exploited, would result in failure bo meet the prormance objectives in Subpare C of 10 CFR Part 6!:

(d) projected population growth and future developments within the region or state where the factlity is to be located are likely to affect the abjity of the disposal facllity to meet the pepfonmence objectives in subpart $C$ of 10 CPR Part 61: and

(1) nearby facllitics or activitics could adversely impact the dispcsal

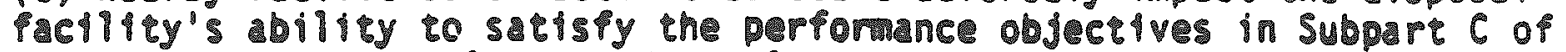
10 CPR Part 61 or cculd significantly mask an environmental monitoring program.

9. The hydrogeologic unit bereath the site shall not discharge ground water to the land surface within the disposal site boundaries.

10. The water tale must be suffictently below the disposal factitey to prevent groundwater intrusion into the waste, with the exception outined under 10 CPR Section $61.50(2)(7)$.

11. In general. areas wh highly vulnerable hydrogeology deserve special atcention in the siting process. Hydrogeology is considered vuinerable when ground-water travel time long any 100-foot flow peth from the edge of the engineared containuent structure is iess than approximately ico years (Critari for Identifying Arees of Vulnerable Hydrogeology Under RCRA-Statutory Incerpretive GuIdance july 1986, Ireprim Final.

(PB-86-224953)). Disposal sites located in ares of vuinerable hydrogeology my regulre axtensive. sibespectifle investigations which could lead to and provide bases for restrictions or modtifications to design or opereting prectlees. How ver. finding that a site is lccaped in an are of vulnerable hydrogeology alone, based on the EPA criterla, is not considered sufficient co prohtblt siting under RCRA. 